\title{
Voortgang in voortgangstoetsing : studies naar de aansluiting van de voortgangstoets op probleemgestuurd onderwijs
}

Citation for published version (APA):

van Til, C. T. (1998). Voortgang in voortgangstoetsing : studies naar de aansluiting van de voortgangstoets op probleemgestuurd onderwijs. [Doctoral Thesis, Maastricht University]. Universiteit Maastricht. https://doi.org/10.26481/dis.19980703ct

Document status and date:

Published: 01/01/1998

DOI:

10.26481/dis.19980703ct

Document Version:

Publisher's PDF, also known as Version of record

Please check the document version of this publication:

- A submitted manuscript is the version of the article upon submission and before peer-review. There can be important differences between the submitted version and the official published version of record.

People interested in the research are advised to contact the author for the final version of the publication, or visit the DOI to the publisher's website.

- The final author version and the galley proof are versions of the publication after peer review.

- The final published version features the final layout of the paper including the volume, issue and page numbers.

Link to publication

\footnotetext{
General rights rights.

- You may freely distribute the URL identifying the publication in the public portal. please follow below link for the End User Agreement:

www.umlib.nl/taverne-license

Take down policy

If you believe that this document breaches copyright please contact us at:

repository@maastrichtuniversity.nl

providing details and we will investigate your claim.
}

Copyright and moral rights for the publications made accessible in the public portal are retained by the authors and/or other copyright owners and it is a condition of accessing publications that users recognise and abide by the legal requirements associated with these

- Users may download and print one copy of any publication from the public portal for the purpose of private study or research.

- You may not further distribute the material or use it for any profit-making activity or commercial gain

If the publication is distributed under the terms of Article $25 \mathrm{fa}$ of the Dutch Copyright Act, indicated by the "Taverne" license above, 


\section{Voortgang in Voortgangstoetsing}

Studies naar de aansluiting van de voortgangstoets op probleemgestuurd onderwijs

\section{PROEFSCHRIFT}

Ter verkrijging van de graad van doctor aan de Universiteit Maastricht, op gezag van de Rector Magnificus,

prof.dr. A.C. Nieuwenhuyzen Kruseman, volgens het besluit van het College van Decanen, in het openbaar te verdedigen op vrijdag

3 juli 1998 om 16.00 uur

door

Cita Theresa van 'Til 


\title{
Promotor
}

Prof.dr. C.P.M. van der Vleuten

\section{Co-promotor}

Dr. H.J.M. van Berkel

\author{
Beoordelingscommissie \\ Prof.dr. H.G. Schmidt (voorzitter) \\ Prol.dr. J.A.M. Maarse \\ Dr. M. Mulder (Universiteit Twente) \\ Dr. J.D.H.M. Vermunt (Rijksuniversiteit Leiden) \\ Prof.dr. W.H.F.W. Wijnen
}

foto's omslag:

Hans wan Dijk, Jolanda van Haastregt

Drukwerk:

Ponsen Looijen, Wageningen

ClP-gegevens Kaninklijke Bibliotheek, Den Haag

Til, Cita Theresa van

Voortgang in Voortgangstoetsing: Studies naar de aansluiting van de voortgangstoets op probleemgestuurd onderwijs / Cita Theresa van Til. - Wageningen: Ponsen \& Looijen. - Proefschrift Maastricht. - Met lit. opg. - Met Engelse samenvatting. ISBN 9056510517

Trefwoorden: voortgangstoets / probleemgestuurd onderwijs / studiegedrag 


Inleiding

1 Toetsing binnen onderwijs: de context 5

Onderwijskundige implicaties van toetsing 5

Probleemgestuurd onderwijs 7

$\begin{array}{ll}\text { Voortgangstoetsing } & 12\end{array}$

De plaats van voortgangstoetsing binnen probleemgestuurd onderwijs 13

2 Vraagtekenoptie bij juist-onjuist vragen: een studie naar verschillen in gebruik en verschillen in toetsresultaten 23

Inleiding en probleemstelling $\quad 23$

$\begin{array}{ll}\text { Methode } & 29\end{array}$

$\begin{array}{ll}\text { Resultaten } & 34\end{array}$

Discussie en conclusie $\quad 43$

3 Probleemgestuurd studiegedrag: een studie naar studiegedrag in relatie tot toetsvoorbereiding en toetsscores $\quad 49$ Inleiding en probleemstelling $\quad 49$

$\begin{array}{ll}\text { Methode } & 57\end{array}$

$\begin{array}{ll}\text { Resultaten } & 62\end{array}$

$\begin{array}{ll}\text { Discussie en conclusie } & 67\end{array}$

4 Regelmaat van studeren: een studie naar de regelmaat van studeren tijdens een blokperiode en de invloed op toetsresultaten

$\begin{array}{ll}\text { Inleiding en probleemstelling } & 73\end{array}$

$\begin{array}{ll}\text { Methode } & 81\end{array}$

Resultaten $\quad 85$

$\begin{array}{ll}\text { Discussie en conclusie } & 93\end{array}$ 
5 Sturend effect van de voortgangstoets: een inventarisatie van de sturing tot specifieke studie-activiteiten $\quad 97$

$\begin{array}{lr}\text { Inleiding en probleemstelling } & 97\end{array}$

$\begin{array}{ll}\text { Methode } & 104\end{array}$

$\begin{array}{ll}\text { Resultaten } & 106\end{array}$

$\begin{array}{ll}\text { Discussie en conclusie } & 112\end{array}$

6 Toetsgerichte studie-activiteiten: een interventie-studie naar de invloed op voortgangstoetsresultaten 117

$\begin{array}{ll}\text { Inleiding en probleemstellingen } & 117\end{array}$

$\begin{array}{ll}\text { Methode } & 120\end{array}$

$\begin{array}{ll}\text { Resultaten } & 124\end{array}$

$\begin{array}{ll}\text { Discussie en conclusie } & 128\end{array}$

7 Conclusie, Discussie \& Implicaties 131

$\begin{array}{ll}\text { Conclusie en Discussie } & 131\end{array}$

Eindconclusie en implicaties 140

$\begin{array}{ll}\text { Samenvatting } & 149\end{array}$

$\begin{array}{ll}\text { Summary } & 157\end{array}$

$\begin{array}{ll}\text { Referenties } & 165\end{array}$

$\begin{array}{ll}\text { Bijlage 1 } & 177\end{array}$

$\begin{array}{ll}\text { Dankwoord } & 179\end{array}$

$\begin{array}{ll}\text { Curriculum Vitae } & 183\end{array}$ 


Binnen elke vorm van onderwijs gaat een sterke sturing uit van toetsing. Studenten stemmen hun activiteiten af op datgene wat wordt getoetst, hoe wordt getoetst en hoeveel zij moeten doen om een toets te halen. De keuzes die worden gemaakt over de wijze waarop getoetst wordt zijn daarom erg belangrijk voor het slagen van een onderwijssysteem. Sterker nog, een onderwijssysteem staat of valt met de wijze waarop de toetsing aansluit bij het onderwijs. Het uitgangspunt dat "elke actie van toetsing resulteert in een onderwijskundige reactie" (Van der Vleuten, 1996) illustreert hoe belangrijk het is bij de opzet, analyse en evaluatie van onderwijs aandacht te besteden aan de invloed die toetsing heeft op het onderwijs en de studenten. De aansluiting van een specifieke vorm van toetsing, voortgangstoetsing, op probleemgestuurd onderwijs en studenten binnen probleemgestuurd onderwijs staat centraal in deze dissertatie.

De Universiteit Maastricht is in 1974 bij de oprichting van de universiteit gestart met een toen voor Nederland unieke wijze van onderwijs, probleemgestuurd onderwijs. Destijds is gekozen voor probleemgestuurd onderwijs vanuit de behoefte in te spelen op veranderende inzichten op het gebied van leren, en bovendien de kennis en vaardigheden van de afgestudeerden beter af te stemmen op hetgeen de maatschappij tegenwoordig van hen verwacht.

De maatschappij is veel complexer geworden; er is sprake van een enorme toename van kennis en technologie die voor een vakgebied belangrijk is. Bovendien is er een veel groter aantal informatiebronnen beschikbaar die toegankelijker is geworden voor een grotere groep mensen. De schijnbaar oneindige mogelijkheden van de multi-media zijn hier een voorbeeld van.

Dit brengt met zich mee dat een afgestudeerde tegenwoordig niet alleen moet beschikken over een hoeveelheid kennis, maar vooral ook over een groot aantal vaardigheden. Voorbeelden hiervan zijn vaardigheden om kennis upto-date te houden. Afgestudeerden moeten vooral in staat zijn de eigen kennis op het juiste moment toe te passen en er op de juiste manier gebruik van te maken. Dit maakt het noodzakelijk dat in de studie aandacht wordt besteed aan vaardigheden als 'levenslang leren' en 'probleem oplossend vermogen'. Het eerste stelt studenten in staat zich hun hele leven verder te on twikkelen en het tweede bevordert dat opgeleiden in staat zijn de kennis en 
vaardigheden die zij hebben te gebruken om nieuwe probleem op te kunnen lossen. Probleengestuurd onderwijs sluit hierop aan (of veronderstelt dit te doen). Het unieke van probleemgestuurd onderwijs is de centrale rol die studenten binnen het onderwijs hebben in het verkrijgen van kennis. Datgene wat door studenten wordt bestudeerd, wordt niet direct maar indirect door de docenten alangestuurd, vanuit (praktijk) problemen die zij studenten aanbieden. Vanuit het volgens een vaste systematiek bespreken van concrete praktijkproblemen, welke plaatsvindt in kleine onderwijsgroepen, bepalen studenten zelf hiaten in hun kennis en daaruit woortwloeiend wat zij gaan bestuderen.

Net als binnen elke vorm van onderwijs moet ook binnen probleemgestuurd onderwijs worden nagegaan of studenten voldoende kennis hebben verkregen. Bij de start van de universiteit werd in eerste instantie gebruik gemaakt van traditionele toetsvormen. Dit leidde tot sterk toetsgericht studiegedrag wat ten koste ging van datgene wat studenten voor de onderwijsgroep deden. Op basis van deze ervaringen concludeerde men dat probleemgestuurd onderwijs om een andere vorm van toetsing vraagt. Doorbroken moest worden dat studenten datgene gingen bestuderen wat zij verwachtten in de toets. Zich daarmee sterker door toetsing lieten sturen in hun studie-activiteiten dan door de problemen uit de onderwijsgroep en zich hierbij sterk lieten beïnloeden door de toetsmomenten. Vanaf 1976 startte men met een op probleemgestuurd onderwijs aansluitende vorm van toetsing, voortgangstoetsing. Met deze vorm van toetsing dacht men een toetsvorm te hebben ontwikkeld die studenten de mogelijkheid laat tot zelfsturing zonder strijdige sturing en eisen vanuit toetsing.

De voortgangstoets richt zich op het eindniveau van de studie door vragen te bevatten over het gehele kennisdomein van deze studie. Ongeacht hur vordering in de studie of de gekozen afstudeerrichting krijgen alle studenten eenzelfde toets voorgelegd. Een vergelijkbare toets wordt een aantal malen per jaar afgenomen.

In diverse publicaties over de voortgangstoets wordt een groot aantal argumenten genoemd waarom deze toetsvorm past binnen probleemgestuurd onderwijs. Omdat de toetsafname niet direct is gekoppeld aan een onderwijsperiode zou worden voorkomen dat studenten toetsgericht gaan studeren. Dit maakt mede mogelijk dat de toets studenten de vrijheid laat zelf te bepalen wat zij gaan bestuderen. Bovendien zorgt de omvang van het kennisdomein dat met de toets wordt bestreken ervoor dat het niet mogelijk is voor de 
toets te studeren. Ook zou de toets elke studie-activiteit belonen en zou de toets feedback geven over nog bestaande kennishiaten. Over de daadwerkelijke invloed op het studiegedrag, en de invloed van dit studiegedrag op toetsresultaten, is veel minder bekend. Vandaar dat de studies die in deze dissertatie worden beschreven met name hierop zijn gericht. In vijf verschillende studies wordt de invloed van toetskenmerken dan wel verondersteld studiegedrag van studenten in relatie tot de voortgangstoets onderzacht, met de daaruit voortvloeiende invloed op toetsresultaten. De centrale vraagstelling van deze dissertatie luidt: "in hoeverre is er sprake van aansluiting tussen het studiegedrag dat de voortgangstoets aanstuurt en het studiegedrag dat met probleemgestuurd onderwijs wordt beoogd?"

In het inleidend hoofdstuk wordt de context geschetst over toetsing binnen onderwijs, met de veronderstelde aansluiting van voortgangstoetsing op probleemgestuurd onderwijs. Het hoofdstuk wordt afgesloten met vijf onderzoeksvragen die voortkomen uit deze veronderstellingen.

Elk van de vijf studies wordt daarna in een apart hoofdstuk beschreven en kan als zodanig ook afzonderlijk worden gelezen. Het streven om elk van de hoofdstukken zodanig te beschrijven dat deze afzonderlijk kunnen worden gelezen maakt dat sommige theoretische achtergronden meermalen worden genoemd. 



\section{Toetsing binnen onderwijs: de context}

In dit eerste hoofdstuk wordt de achtergrond van het belang van aandacht voor de onderwijskundige implicaties van toetsing toegelicht. Vanuit de visie dat elke onderwijskundige context vraagt om een daarop afgestemde vorm van toetsing wordt uitleg gegeven over probleemgestuurd ondenwijs en de op deze onderwijsmethodiek afgestemde vorm van toetsing, de voortgangstoets, uiteengezet. De invloed van de onderwijsmethodiek en de voortgangstoets op de studieactiviteiten van studenten staan centraal, waarbij verondersteld wordt dat de afzonderlijke invloed van het onderwijs en de toets op elkaar aansluiten. Hierbij zullen zowel ten aanzien van de opzet van het (probleemgestuurd) onderwijs als de opzet van de voortgangstoets aspecten worden benoemd die specifiek gelden voor de Faculteit der Gezondheidswetenschappen. Het hoofdstuk zal worden afgesloten met de onderzoeksuragen die in dit proefschrift op basis van empirisch onderzoek zullen worden onderzocht.

\section{Onderwijskundige implicaties van toetsing}

Toetsing heeft een enorme invloed op het studeergedrag van studenten. Deze invloed bestaat volgens Cizek (1993) omdat met de toekenning van cijfers aan toetsen gedrag van studenten wordt beloond of afgestraft. Studenten reageren op toetsen door datgene te gaan bestuderen wat zij verwachten datt getoetst zal worden. Zij verrichten daarbij de studie-activiteiten welke naar hun verwachting voldoende zijn om de toets te halen (Frederiksen, 1984). Snyder (1971) kent dan ook een zeer grote macht toe aan toetsing, hij concludeert dat de sturende werking die van toetsen uitgaat dusdanige vormen kan aannemen dat hiermee een gekozen onderwijssysteem ondermijnd kan worden.

De grote invloed van toetsing kan ook op een positieve manier worden gebruikt. Zo stelt Linn (1993) dat toetsing kan dienen als sleutel om, zowel 
studenten als docenten, te motiveren tot harder werken. Bovendien kan het sturend effect van toetsing worden gebruikt voor het implementeren van bepaalde onderwijspolitiek (Linn, 1993). Een voorbeeld daarvan wordt genoemd door Frederiksen (1984): toetsen verhogen de tijd en inspanning in leren en doceren voor datgene dat wordt getoetst (gegeven dat de omvang van tijd en inspanning stabiel zijnj, ten koste van de inspanning voor leren en doceren voor kennis en vaardigheden welke niet worden getoetst. Het is volgens Van der Vleuten (1996) dan ook de uitdaging voor de makers van onderwijs om de sturende werking van toetsen in positieve zin uit te buiten, om op deze manier te bewerkstelligen dat studenten de gewenste studieactiviteiten verrichten. Norman (1991) stelt hetzelfde, en voegt hieraan toe dat daarbij nagedacht dient te worden over de vraag hoe studenten te helpen bij het evalueren van hun leren op de manier zoals door het onderwijs wordt bedoeld.

Aan het gebruiken van toetsing als sturend instrument kleeft echter wel een aantal complicaties. Wijnen en Van der Vleuten (1985) noemen het gevaar voor te sterk toetsgericht studiegedrag, waarmee zij erop doelen dat studenten alleen nog van toets naar toets gaan werken in de vorm van een soort hordeloop. Volgens Frederiksen (1984) bestaat de kans dat de kennis en vaardigheden die het eenvoudigst en voordeligst kunnen worden getoetst, degene zijn die worden onderwezen.

In de aandacht voor de onderwijskundige implicaties van toetsing bestaat volgens Cizek (1993) een eeuwig conflict tussen psychometrici en curriculumexperts. In deze tweestrijd spelen betrouwbaarheids- en validiteitsoverwegingen enerzijds en argumenten over de consequenties voor het onderwijs en de studie-activiteiten van studenten anderzijds een rol (Norman, Van der Vleuten \& De Graaff, 1991). De discussie wordt met name veroorzaakt door het verschil in onderwijsvisie en visie op leren (Cizek, 1993).

De stelling van Van der Vleuten (1996) "elke actie van toetsing resulteert in een onderwijskundige reactie" (pag. 52) vormt een belangrijk uitgangspunt van de curriculum-experts. De bij-effecten van toetsing op het studiegedrag van studenten zijn moeilijk te voorspellen en kunnen soms zelfs volledig tegengesteld zijn aan de verwachtingen. Daarom is volgens hem het belang van evaluatie en analyse van de onderwijskundige implicaties zeer groot. Een dringende oproep werd gedaan om meer systematisch onderzoek te verrichten om precies na te gaan wat voor effecten verwacht kunnen worden 
van verschillende toetsstrategieën (Van der Veuten et al., 1994). De argumenten van Linn (1993) sluiten hierop aan. Hij stelt dat toetsen niet alleen moeten worden gekozen op basis van het beroep dat zij doen op objectiviteit, maar eerder op de toepasbaarheid van de toets om de specifieke bedoelingen van de onderwijssetting te volgen. Hoewel dit moeilijk is te meten moet aandacht worden besteed aan zowel de positieve als negatieve bijeffecten van toetsing op het onderwijs.

Het moge duidelijk zijn dat de keuzes voor bepaalde vormen van toetsing verschillen van situatie tot situatie, en van instituut tot instituut, afhankelijk van lokale omstandigheden zoals de specifieke onderwijskundige context, beschikbare bronnen, attitudes van docenten en studenten, gewoonten of procedures, etc. (Norman, Van der Vleuten \& De Graaff, 1991). Beslissingen over een toetsvorm moeten de consequentie zijn van zorgvuldige overwegingen die voortkomen uit het doel van de testsituatie in de vorm van praktische toepasbaarheid, onderwijskundige invloed en acceptatie, in plaats van exclusieve toepassing van dogma's met betrekking tot psychometrische eigenschappen.

\section{Probleemgestuurd onderwijs}

Uit eigen ervaring weet iedereen dat het een illusie is binnen onderwijs aan te nemen dat datgene wat aangeboden wordt in lesmaterialen, tijdens colleges, etc. direct, onaangetast, compleet en op correcte wijze terechtkomt in het hoofd van studenten. Aan het verkrijgen van de kennis en vaardigheden ligt een leerproces ten grondslag waar onderwijs een bijdrage aan levert, maar waar studenten zelf het grootste aandeel in hebben.

De kennis opgedaan in de cognitieve psychologie omtrent de concrete verwerving van kennis en de werking van het geheugen geven gestalte aan de theoretische basis voor de vormgeving van probleemgestuurd onderwijs (Norman \& Schmidt, 1992). Gestreefd wordt naar concrete kennis die tijdens die studie wordt verkregen, liefst over langere periode wordt onthouden en die men zich herinnert in situaties waarin deze kennis van belang is. Bovendien is het noodzakelijk dat de kennis (later) wordt toegepast daar waar deze noodzakelijk en relevant is. Dit proces van blijvende en toepasbare kennisverwerving verloopt niet automatisch. Studenten hebben hiervoor de eerder 
genoemde vaardigheden als 'levenslang leren' en 'probleemoplossend vermogen' nodig, waarbij het aanleren van deze vaardigheden een plaats moet hebben in het onderwijs. De doelstellingen van probleemgestuurd onderwijs zijn door de grondleggers Barrows en Tamblyn (1980) samengevat als:

1. het verwerven van kennis, die onthouden wordt en bruikbaar is,

2. het leren te leren (self-directed learning),

3. het leren analyseren en oplossen van problemen.

\section{Vormgeving van probleemgestuurd onderwijs}

Binnen probleemgestuurd onderwijs krijgen studenten een centrale rol in het sturing geven aan hun eigen studie-activiteiten. Met behulp van de gehanteerde onderwijsmethodiek wordt gebruik gemaakt van cognitieve leerprincipes die het leren bevorderen en worden studenten aangezet tot het zelf richtinggeven aan de studie-activiteiten.

Het curriculum binnen probleemgestuurd onderwijs is thematisch en multidisciplinair van opzet. De spil wordt gevormd door de onderwijsgroepen, die worden ondersteund met (vaardigheids-! trainingen, practica en colleges.

In de onderwijsgroepen, groepjes van acht tot twaalf studenten, wordt door studenten onder begeleiding van een docent of ouderejaars student, een tutor, aan problemen gewerkt. Meestal bestaat een probleem uit de beschrijving van een verzameling fenomenen of gebeurtenissen die uit de praktijk voortkomen. Deze verschijnselen moeten door de groep worden geanalyseerd en verklaard in termen van onderliggende principes, mechanismen of processen. De groepsdiscussie en het bestuderen van relevante studie-bronnen staan de studenten ter beschikking om de problemen op te lossen (Moust, Bouhuijs \& Schmidt, 1997).

Een veel gehanteerde methodiek voor het bespreken van taken is de zevensprong (of varianten hierop). De stappen van de zevensprong worden weergegeven in tabel 1.1, en zullen vervolgens één voor éen worden toegelicht. 
Tabel 1.1 De stappen van de zevensprong

Stap 1: onduidelijke termen en begrippen verhelderen

Stap 2: definiëren van het probleem

Stap 3: analyseren van het probleem

Stap 4: op systematische wijze de verschillende verklaringen (uit stap 3) inventariseren

Stap 5: formuleren van leerdoelen

Stap 6: zaeken vam aanwullende informatie buiten de groep

Stap 7: synthetiseren en testen van de nieuwe informatie

Uit: "Probleemgestuurd leren ( $3^{e}$ editie)", door Moust, J. H. C., Bouhuijs, P.A.J., Schmidt, H.G., 1997, Groningen: Wolters-Noordhoff.

Onduidelijke termen en begrippen verhelderen. In eerste instantie wordt in de groep nagegaan of de taak voor iedereen duidelijk is. Onduidelijke termen of begrippen worden aan elkaar uitgelegd. In deze fase gaat het erom dat onderling dezelfde betekenis wordt gehecht aan de verschillende termen in de probleembeschrijving.

Definiëren van het probleem. De volgende stap bestaat uit het helder en precies definiëren van het probleem. In deze fase bepaalt de groep welke verschijnselen in onderlinge samenhang verklaard dienen te worden.

Analyseren van het probleem. Vervolgens wordt besproken wat de verschillende groepsleden denken, weten of denken te weten over de processen en mechanismen die ten grondslag liggen aan het probleem. Hierbij is het van belang dat niet alleen feitelijke informatie wordt besproken, maar vooral ook dat op basis van gezond verstand mogelijke verklaringen worden geformuleerd. De groep dient ernaar te streven dat het bedenken van ideeën wordt gescheiden van het kritisch beoordelen van deze ideeën.

Op systematische wijze de verschillende verklaringen inventariseren. Tijdens de volgende stap worden de problemen geordend en kritisch besproken. De studenten moeten proberen de interne samenhang en onderlinge afhankelijkheid van de benoemde ideeën te vinden, waarbij relevante en irrelevante kenmerken van elkaar worden gescheiden. Verschillende opvattingen worden vervolgens uitgediept, ideeën worden kritisch besproken en met elkaar vergeleken. In deze fase dient duidelijk te worden wat door de studenten nog niet wordt begrepen en wat de tegenstellingen zijn, waardoor duidelijk wordt wat nader bestudeerd dient te worden.

Formuleren van leerdoelen. Op basis van de vragen of onduidelijkheden die aanwezig zijn in de groep worden leerdoelen geformuleerd. Deze leerdoelen vormen de uitgangssituatie voor de zelfstudie. 
Zoeken van aanvullende informatie buiten de groep. Gedurende de periode tussen twee onderwijsgroepsbijeenkomsten dienen studenten individueel de leerstof te bestuderen. Het studeren dient te leiden tot een beter begrip van het probleem. Hierbij wordt niet alleen naar een antwoord op de leerdoelen gezocht maar wordt de informatie ook binnen een breder kader geplaatst. Bij de zelfstudie is het tevens belangrijk dat studenten zich afvragen of zij de nieuwe informatie hebben begrepen, of zij deze kunnen verwoorden in de onderwijsgroep en welke vragen zij nog hebben.

Synthetiseren en testen van de nieuwe informatie. In de eerstvolgende onderwijsgroepsbijeenkomst wordt door de studenten gerapporteerd wat de zelfstudie, aan de hand van de leerdoelen, heeft opgeleverd. Bij de rapportage worden niet alleen antwoorden gegeven op de leerdoelen, maar kan tevens in de groep worden nagegaan of de stof voldoende is begrepen, het bestudeerde voldoende breed en diepgaand was en kan aanvullende uitleg worden gevraagd of gegeven aan medestudenten.

De onderwijsgroepsbijeenkomsten vinden twee keer per week plaats, met daartussen voldoende gelegenheid voor zelfstudie. Elke bijeenkomst wordt één taak nabesproken en éẻn taak voorbesproken (die in de volgende onderwijsgroepsbijeenkomst wordt nabesproken).

In aanvulling op de onderwijsgroepen kunnen er enkele colleges worden gegever. Colleges hebben binnen probleemgestuurd onderwijs echter een ondergeschikte rol. Daarnaast hebben de vaardigheidstrainingen en practica veelal een plaats binnen een probleemgestuurd curriculum. Het doel van vaardigheidsonderwijs is studenten voor te bereiden op contacten met de praktijk. De student moet leren de getrainde vaardigheden technisch juist, systematisch, geïntegreerd en gericht te kunnen uitvoeren. Vaardigheidstrainingen sluiten zo nauw mogelijk aan bij de leerstof in de blokken, zodat beide onderdelen elkaar ondersteunen en versterken en niet beconcurreren. De practica zijn bedoeld om studenten de gelegenheid te bieden hun kennis en inzicht in een bepaalde discipline 'praktisch' te oefenen, ter ondersteuning van het leerproces door middel van illustratie en toepassing van het gelleerde.

\section{Kennisverwerving en probleemgestuurd onderwijs}

Om meer kennis te krijgen dient nieuwe informatie te worden opgeslagen in het geheugen. Het geheugen kan daarbij gezien worden als een netwerk. Informatie (of concepten) met een bepaalde betekenis en relatie worden met 
elkaar verbonden. Wanneer een groot aantal van deze verbindingen, proposities genoemd, onderling gerelateerd wordt vormen zij gezamenlijk een netwerk (zie bijwoorbeeld Gagné, Walker-Yekovich \& Yekovich, 1993).

Met het toevoegen van informatie aan dit netwerk vindt kennistoename in een bepaald (vak)gebied plaats. Deze uitbreiding kan bestaan uit het toevoegen van nieuwe informatie aan het netwerk. Het netwerk wordt dan groter. De uitbreiding kan ook bestaan uit het versterken van het netwerk. Er worden meer onderlinge relaties gelegd tussen de verbindingen. De structuur van een dergelijk betekenisvol netwerk is persoonsgebonden en vormt de neerslag van alle ervaringen, opvattingen en ideeën die de persoon in zijn leven heeft opgedaan.

In twee review artikelen zijn de belangrijkste inzichten omtrent cognitieve factoren die een belangrijke invloed hebben op het verkrijgen en onthouden van kennis op een rijtje gezet (Norman \&6 Regehr, 1994; Schmidt, 1993). De auteurs noemen: activeren van voorkennis, (her-)structurering van kennis, elaboratie, leren in context ter bevordering van transfer en motiverend onderwijs.

Met het doorlopen van de stappen van de zevensprong wordt op de volgende manier ingespeeld op deze cognitieve leerprincipes. Activeren van voorkennis vindt met name plaats bij 'onduidelijke begrippen verklaren' en 'probleem analyseren'. Kennis (her-) structureren vindt plaats bij 'verklaringen systematisch inventariseren', waar een voorlopig netwerk wordt opgezet, en bij de laatste stap 'de nieuwe informatie toetsen', waar de juistheid van het nieuwe netwerk wordt getoetst. Studenten elaboreren wanneer ze vooraf proberen het probleem te verklaren op basis van logica en voorkennis (stap 3 en 4), het gericht zoeken van antwoorden op leerdoelen (stap 6) en door het verwoorden / rapporteren van de antwoorden op de leerdoelen (stap 7). Leren vindt plaats vanuit een context, de context van de taak met zijn probleemstelling ( $\operatorname{stap} 2$ ) en de context van de leerdoelen (stap 6). De context van de taak wordt gevormd door een probleem dat relevant is voor de latere beroepspraktijk en het studeren om de leerdoelen te beantwoorden werkt motiverend omdat studenten gericht gaan studeren om hun gebleken kennishiaten te gaan opvullen.

Centraal in de opzet is de veronderstelling dat leereffecten vooral het gevolg zijn van kenmerken en activiteiten van studenten. Idealiter is de student actief bezig; worsteit met problemen, discussieert, 'doceert', wordt geconfron- 
teerd met verschillende opvattingen en probeert zich een vruchtbaar perspectief op het onderwerp eigen te maken door midclel van het zoeken, bestuderen en uitleggen van relevante leerstof.

\section{Voortgangstoetsing}

De voortgangstoets is een vorm van longitudinale toetsing binnen een bepaald kennisdomein waarbij de vragen het eindniveau van de betreffende studie reflecteren (Verwijnen \& Imbos, 1978; Van der Vleuten, 1990; Wijnen, 1977; Wijnen \& Van der Vleuten, 1985; Wijnen, 1993). De toets wordt een aantal keren per jaar, op vaste momenten in het jaar, afgenomen bij alle studenten, ongeacht hun vordering in de studie of de gekozen afstudeerrichting. Elke toets vormt een weerspiegeling van hetzelfde te toetsen kennisdomein, het kennisdomein van de betreffende studie. De vragen worden volgens een vaste blauwdruk uit het kennisdomein binnen verschillende relevante (sub-)categorieën aangeleverd door leden van de staf uit verschillende disciplines, waarbij voor elke afname gebruik wordt gemaakt van nieuwe items. Met deze vorm van toetsing ontbreekt een directe koppeling tussen het gevolgde onderwijs en de inhoud van de toets. Bovendien is op deze manier de inhoud van de vragen en daarmee de inhoud van de toets vergelijkbaar aan de voorgaande en is de toets evenals het curriculum multidisciplinair van aard.

Na afloop van de toets ontvangen studenten gedetailleerde feedback over hun kennisniveau op de verschillende categorieën, en de toets in zijn geheel, ten opzichte van hun medestudenten in dezelfde jaargroep (en eventueel afstudeerrichting). Dit stelt hen in staat voor zichzelf hiaten in kennis ten opzichte van hun medestudenten vast te stellen (Van Berkel, Sprooten \& De Graaff, 1993; Van der Vleuten, Scherpbier, Wijnen \& Snellen, 1996).

De vragen van de voortgangstoets zijn van het type juist/?/onjuist. Het toetsresultaat wordt bepaald door de goed min fout score. Voor elk goed antwoord wordt een score 1 en voor elk fout antwoord een score -1 gegeven. De keuze voor deze vraagvorm was in eerste instantie vooral een pragmatische (Van der Vleuten, 1990). Met deze vraagvorm kunnen studenten namelijk in korte tijd een groot aantal vragen beantwoorden, hetgeen de vraagvorm geschikt maakt om in 'beperkte" tijd een uitgebreid kennisdomein te 
toetsen (Dousma, Horsten \& Brants, 1997; Wijnen, 1973; Wijnen, 1977 ). Wanneer studenten het antwoord op een vraag (nog) niet weten kunnen zij gebruik maken van de vraagteken-optie. Deze vraagtekenoptie, of het onbeantwoord laten van de vraag, heeft geen invloed op de eindscore.

De vraagtekenoptie doet bovendien recht aan het gegeven dat studenten niet in staat zullen zijn alle vragen te beantwoorden. Zeker niet degenen die zich nog bevinden aan het begin van hun studie.

\section{De plaats van voortgangstoetsing binnen probleemgestuurd onderwijs}

In de eerste paragraaf van dit hoofdstuk is het belang van de aanshuiting van een toetssysteem op het onderwijs uiteengezet. Kennis en vaardigheden die bij probleemgestuurd onderwijs aan bod komen zijn 'zelfgestuurd leren", 'probleemoplossend vermogen' en 'geelaboreerde kennis' die op langere termijn wordt onthouden en toegankelijk is (Barrows \& Tamblyn, 1980). Norman (1988) schrift over dit soort kennis dat meer ontwikkelde kennis leidt tot een kennisnetwerk dat niet alleen groter is, maar bovendien sterker gestructureerd. Een dergelijk netwerk maakt het mogelijk dat men zich ook op langere termijn kennis herinnert. Kennistoetsing binnen probleemgestuurd onderwijs moet daarom niet zijn gericht op verspreide losse feitenkennis, maar op samengestelde toepassingskennis; kennis die zich heeft ontwikkeld over een langere periode (Swanson, Case \& Van der Vleuten, 1991). Alleen kennis toetsen met behulp van multiple choice toetsen, waatin elk item als een geisoleerd feit wordt beschouwd, levert geen stimullus op die representatief is voor de studie-activiteiten die worden gewenst (Norman, 1991). Norman acht het dan ook wenselijker om kennis te toetsen binnen een relevante context. Echter, ook het toetsen van bepaalde feiten acht hij niet misplaatst, omdat het belangrijk is na te gaan of studenten beschikken over voldoende parate kennis. In het belang van zowel studenten, de faculteit. en bijvoorbeeld de onderwijsinspectie moet met toetsing zichtbaar worden gemaakt dat studenten beschikken over voldoende (parate) kennis. Het is daarom belangrijk dat kennistoetsing ook binnen probleemgestuurd onderwijs serieus wordt genomen. Wel moet worden vermeden dat deze kennistoetsing leidt tot studie-activiteiten welke ten koste gaan van de zelfsturing 
van studenten in hun activiteiten voor en in de onderwijsgroepen (Wijnen, 1.993).

Kennistoetsing bij probleemgestuurd onderwijs moet volgens Wijnen en Bouhuijs (1986) studenten de vrijheid laten hun eigen (individuele) leerroutes te bepalen en bovendien een eerlijke inschatting geven van hun kennis. Wanneer in probleemgestuurd onderwijs kennisverwerving in aansluiting op de motivatie van de studenten wordt gestimuleerd, ligt het volgens Wijnen en Van der Vleuten (1985) en Wijnen (1993) minder voor de hand om studieresultaten te toetsen in de vorm van nauwkeurig omschreven deel-prestaties. Ook uniforme toetsing op afgebakende kennisgebieden doet volgens hen geen recht aan de mogelijkheid van individuele studenten of onderwijsgroepen om binnen het onderwijsprogramma individuele accenten te leggen.

\section{Verrichte studies en vraagstellingen}

Eerder in dit hoofdstuk is al aangegeven dat de keuze voor toetsmethodieken niet enkel moet plaatsvinden op basis van psychometrische eigenschappen van het instrument, maar eerder op de toepasbaarheid binnen de specifieke onderwijskundige context. Ten aanzien van voortgangstoetsing is over de betrouwbaarheid en validiteit van de toets inmiddels vrij veel onderzoek verricht (Van Berkel et al., 1993; Van Berkel, 1990; Blake, Norman, Keane, Mueller, Cunnington \& Didyk, 1996; Van Leeuwen, 1995; Pollemans, 1994; Van der Vleuten, Verwijnen 86 Wijnen, 1996). De studies uit deze dissertatie zijn gericht op de invloed van toetskenmerken of verondersteld studiegedrag van studenten op voortgangstoetsing binnen probleemgestuurd onderwijs. Telkens vormen veronderstellingen die in diverse publicaties over de voortgangstoets worden geformuleerd over aansluiting op het onderwijs en (ontbrekende) invloed op studiegedrag het uitgangspunt. In de beantwoording van de centrale probleemstelling van deze dissertatie "in hoeverre is er sprake van aansluiting tussen het studiegedrag dat de voortgangstoets aanstuurt en het studiegedrag dat met probleemgestuurd onderwijs wordt beoogd?" worden per studie de argumenten met de daarbij behorende vraagstelling hieronder opgesomd.

In de eerste studie, de studie welke beschreven wordt in hoofdstuk 2, staat het gebruik van de vraagtekenoptie met de gehanteerde scoringsregel 'goedmin-fout" centraal. De vrijheid binnen probleemgestuurd onderwijs om van- 
uit eigen interesses te studeren en kennishiaten te bepalen wormt een belangrijk argument voor het hanteren van een vraagtekenoptie. Studenten zouden de vrijheid in leerroutes moeten terugvinden in de toets door de mogelijkheid om in een toets niet alles (al) te moeten weten. In de voortgangstoets wordt kennis gemeten welke is ontleend aan het eindniveau wan de studie, waarbij de toetsafname niet direct gekoppeld is aan een afgeronde onderwijsperiode. Dit zou studenten de vrijheid geven zelf te bepalen wanneer zij wat gaan bestuderen.

De goed-min-fout scoring heeft als doel dat studenten worden ontmoedigd te gokken (Van der Vleuten, Verwijnen \& Wijnen, 1996).

Op psychometrische gronden wordt over het algemeen aangeraden niet te corrigeren voor gokken (onder andere Ebel, 1970: Gross, 1982). Gokcorrectie verlaagt de betrouwbaarheid en introduceert oncontroleerbare fouten-variantie tussen studenten die verschillende 'gokstrategieën' gebruiken. De vraagteken-optie wordt ondanks deze bezwaren met name op eerder genoemde inhoudelijke gronden toch gehanteerd.

Naast het in kaart brengen van het gebruik van de vraagtekenoptie en de omvang van antwoorden op basis van gokken, dan wel kennis, wordt onderzocht in hoeverre er sprake is van verschillen tussen (groepen) studenten in antwoordgedrag. De probleemstelling van dit onderzoek luidt: "zijn er verschillen tussen studenten in de mate waarin zij gebruik maken van de vraagtekenoptie en in hoeverre zijn deze (eventuele) verschillen van invloed op het resultaat op de voortgangstoets?"

De tweede studie (hoofdstuk 3) richt zich op studiegedrag dat specifiek is voor probleemgestuurd onderwijs; gedrag van studenten in de onderwijsgroep en tijdens de zelfstudie dat voortkomt uit de onderwijsmethodiek. Binnen probleemgestuurd onderwijs zijn de studie-activiteiten van studenten in de onderwijsgroepen gericht op het verkrijgen van kennis die op langere termijn wordt onthouden en waarbij studenten in staat zijn deze kennis toe te passen in andere contexten (Barrows \& Tamblyn, 1980). Variatie tussen studenten in hun vaardigheden om zelfgestuurd (ofwel probleemgestuurd) te leren, in combinatie met cognitieve vermogens, zullen leiden tot variaties in leereffect (Swanson et al., 1991). De kwaliteit van dit leerproces wordt volgens Swanson et al. indirect gemeten met het toetsen van kennis die inmiddels enige tijd geleden in de studie aan bod is geweest. 
De voortgangstoets beoogt het meten van dit soort kennis; functionele kennis in plaats van korte termijn kennis (Van der Vleuten, Scherpbier, et al., 1996). De herhaling van de toetsafname, en het longitudinale karakter van de toets, zou maken dat de nadruk van de toets ligt op functionele in plaats van gedetailleerde en snel vergeten feiten (Van der Vleuten, Verwijnen 8 Wijnen, 1996). Individuele zelfstudie-activiteiten en activiteiten in de onderwijsgroep zouden worden teruggezien in groei op de voortgangstoets (Van der Vleuten, Verwijnen \& Wijnen, 1996; Wijnen, 1993), waarbij elke studie-inspanning zou worden beloond (Sprooten \& Van der Vleuten, 1983). Naast het in kaart brengen van verschillen tussen studenten in hun probleemgestuurd studiegedrag wordt nagegaan of studenten verschillen in wijze van voorbereiding op de voortgangstoets en het binnen probleemgestuurd onderwijs veronderstelde studiegedrag en resultaten op de voortgangstoets. De probleemstelling van deze studie luidt: "zijn er verschillen tussen studenten in probleemgestuurd studiegedrag en hun voorbereiding op de voortgangstoets en de resultaten die zij op de voortgangstoets behalen?"

De dercle studie (hoofdstuk 4) richt zich op de regelmaat van studieactiviteiten voor de onderwijsgroep tijdens een blokperiode, die voldoende zou moeten zijn als voorbereiding op de toetsen. Het regelmatig werken in en voor de onderwijsgroepen aan de eigen leerdoelen veronderstelt voldoende voorbereiding voor studenten om hun kennis automatisch te zien toenemen. Met het ontbreken van een directe koppeling tussen het onderwijs dat wordt gevolgd en de toetsafname zal worden voorkomen dat studenten studeren om een toets te halen. Hiermee zou volgens Van der Vleuten, Scherpbier, et al. (1996) en Wijnen (1993) worden aangesloten op het uitgangspunt dat voor studenten het zelfgestuurd leren, met het formuleren van eigen leerdoelen, de belangrijkste leidraad vormt. Studenten kunnen zich volgens hen daardoor blijven concentreren op de studie-activiteiten voor de onderwijsgroep. Een ander argument dat door deze auteurs wordt genoemd is de mogelijkheid voor studenten zich te richten op het begrijpen en kunnen toepassen van kennis in plaats van memoriseren van kennis gericht op het halen van een toets. In de voortgangstoets zouden studenten deze kennis dan niet alleen hoeven te tonen in de vorm van kleine weet-feitjes, maar ook moeten toepassen. Omdat de voortgangstoets zich richt op continue 
evaluatie van eerder geleerde stof wordt voorkomen dat studenten een steeds terugkerende druk voelen om een toets te halen en hier fop het laatste moment) voor gaan studeren ten koste van andere studie-activiteiten (Van der Vleuten, Scherpbier, et al., 1996).

In de studie is naast het in kaart brengen wan de regelmaat van activiteiten voor de onderwijsgroep nagegaan of verschillen tussen studenten in het regelmatig spreiden van studie-activiteiten zijn terug te zien in studieresultaten. De probleemstelling van deze studie luidt: "hoe is de verdeling van studie-activiteiten rond het ondenwijs binnen een blokperiode en in hoeverre is een gelijkmatige spreiding hiervan gerelateerd aan resultaten op de woortgangstoets?"

De vierde studie, beschreven in het vijfde hoofdstuk, is gericht op de sturing van de voortgangstoets tot toetsgerichte studie-activiteiten. Met het verbreken van de directe relatie tussen het onderwijsprogramma en toetsing wordt verondersteld dat toetsgericht studiegedrag wordt voorkomen (Van der Vleuten, Verwijnen 8 Wijnen, 1996). Omdat studenten niet weten wat zal worden getoetst wordt toetsgericht studeren niet mogelijk verondersteld (Van der Vleuten, Scherpbier, et al., 1996). Van der Vleuten, Verwijnen en Wijnen suggereren dat dit, in combinatie met het niet bedreigende karakter van de toets, maakt dat studenten vertrouwen op hun activiteiten voor de onderwijsgroep. Toch blijkt uit de studies beschreven in hoofdstuk 3 en 4 dat er door studenten voor de toets gestudeerd wordt. In deze studie wordt specifiek nagegaan tot welke studie-activiteiten studenten worden aangestuurd en wordt gezocht naar aanwijzingen voor effecten of ontbrekende effecten van deze activiteiten. De probleemstelling van deze studie luidt: "in welke mate worden de studie-activiteiten wan studenten gestuurd door de voortgangstoets en in hoeverre zijn deze (eventuele) activiteiten gerelateerd aan de prestaties op de voortgangstoets?"

De laatste studie (hoofdstuk 6) die in deze dissertatie wordt beschreven betreft een interventiestudie waarin het effect van gerichte toetsvoorbereiding op toetsresultaten wordt onderzocht. Ondanks de genoemde veronderstellingen blijkt niet voorkomen te kunnen worden dat er op betrekkelijk grote schaal voor de voortgangstoets toetsgericht wordt gestudeerd. De genoemde argumenten het is voor studenten moeilijk om zich specifiek voor te bereiden 
diegedrag wordt niet beloond' (Sprooten \& Van der Vleuten, 1983) en 'de nadruk van de voortgangstoets ligt toch op functionele kennis in plaats van feitenkennis' (Van der Vleuten, Verwijnen \& Wijnen), blijkt niet voorkomen te kunnen worden dat studenter wel toetsgericht gaan studeren. Op basis van de eerdere studies blijft onduidelijk wat het effect is van toetsgerichte studieactiviteiten. Dit vormt de aanleiding voor de laatste studie, met als centrale probleemstelling: "is er een effect van gerichte studie-activiteiten in voorbereiding op de voortgangstoets op het toetsresultaat?"

\section{De context van de verrichte studies}

Het curriculum Gezondheidswetenschappen volgens Probleemgestuurd onderwijs Het onderwijsprogramma van de opleiding Gezondheidswetenschappen bestaat uit een (deels) gezamenlijke propedeuse, drie doctoraalstromen (of differentiaties) met tien specialisaties (afstudeerrichtingen), het keuzeonderwijs en tenslotte een individuele stage. De drie stromen zijn de maatschappijwetenschappelijke (M) stroom, de biologische (B) stroom en de gedragswetenschappelijke (G) stroom. De tien specialisaties worden in regulier en/of als vrijstellingenprogramma in een voltijdse en/of deeltijdse variant aangeboden (zie figuur 1.1)

\begin{tabular}{|c|c|c|c|c|}
\hline \multicolumn{2}{|c|}{ jaar 1} & \multicolumn{2}{|l|}{ jaar 3} & aar 4 \\
\hline \multirow{7}{*}{ Propedeuse } & \multirow{2}{*}{$\begin{array}{l}\text { Biologische } \\
\text { differentiatie }\end{array}$} & Biologische Gezondheidkunde & \multirow{7}{*}{$\begin{array}{l}\text { Keuze. } \\
\text { ondenwijs }\end{array}$} & \multirow{7}{*}{$\begin{array}{l}\text { Stage en } \\
\text { scriptie }\end{array}$} \\
\hline & & Bewegingswetenschappen & & \\
\hline & \multirow{2}{*}{$\begin{array}{l}\text { Gedragswetenschap- } \\
\text { pellike differentiatie }\end{array}$} & Gezondheidswoorlichting & & \\
\hline & & Geestelijke Gezondheidkunde & & \\
\hline & \multirow{3}{*}{$\begin{array}{l}\text { Maatschappijweten- } \\
\text { schappelijke } \\
\text { diflerentiatie }\end{array}$} & Beleid en Beheer & & \\
\hline & & Verplegingswetenschap & & \\
\hline & & $\begin{array}{l}\text { Theorie van de Gezondheids- } \\
\text { wetenschappen }\end{array}$ & & \\
\hline
\end{tabular}

Figuur 1.1 Opbouw van het curriculum van Gezondheidswetenschappen

${ }^{1}$ De recentelijk ontwikkelde studierichtingen en afstudeervarianten Opleidingskunde voor de Gezondheidszorg, Zorgwetenschap en Arbeid \&. Gezondheid zijn niet opgenomen in tiguur 1.1 
Tijdens de laatste twee blokperioden van de propedeuse kiezen studenten voor één van de drie differentiaties van het onderwijsprogramma. Hierna kunnen studenten uit de verschillende differentiaties zich vanaf de vierde blokperiode in het tweede studiejaar verder specialiseren door het kiezen voor één van de verschillende afstudeerrichtingen. Elk studiejaar bestaat uit zes of zeven onderwijsperioden c.q. blokperioden van zes weken. Binnen elk blok vinden twee maal per week onderwijsgroepsbijeenkomsten van twee uur plaats. In de onderwijsgroepen vormen problemen (taken of casus genoemd) de aanleiding voor de groepsdiscussie. Deze taken worden meestal besproken met behulp van de zevensprong. Het werken in de onderwijsgroepen heeft naast het inhoudelijke doel van kennisverwerving ook een vormende doelstelling: studenten leren te werken in een groep vanuit de rol van groepslid en gespreksleider.

\section{Toetsing bij Gezondheidswetenschappen}

Bij Gezondheidswetenschappen vindt kennistoetsing plaats in de vorm van bloktoetsen en voortgangstoetsen. De voortgangstoets wordt drie keer per jaar afgenomen bij alle studenten, ongeacht de studiefase en de gekozen afstudeerrichting. Bloktoetsen worden zes of zeven keer per jaar in aansluiting op de verschillende onderwijsperioden afgenomen.

\section{De voortgangstoets}

De voortgangstoets bij Gezondheidswetenschappen bevat vragen over het hele kennisdomein Gezondheidswetenschappen, waarbij opgemerkt dient te worden dat het kennisdomein Gezondheidswetenschappen zeer divers is. Tijdens de studie komen studenten niet in aanraking met het hele kennisdomein, maar alleen met een algemeen gezondheidswetenschappelijk deel en een specifiek deel dat gerelateerd is aan de eigen afstudeerrichting. Dit maakt het argument van 'met de vraagtekenoptie recht doen aan het feit dat studenten niet alles (all hoeven te weten' des te belangrijker voor de Faculteit der Gezondheidswetenschappen.

Iedere voortgangstoets resulteert in een summatieve score op een vierpuntsschaal. Binnen de eigen jaargroep krijgt een vast percentage studenten op basis van hun goed-min-fout score de toekenning 'onvoldoende', 'twijfelachtig', 'voldoende' of 'goed'. Een onvoldoende score op de ene toets kan gecompenseerd worden met voldoende scores op volgende toetsen (Studiegids Gezondheidswetenschappenj. 
De voortgangstoets heeft in de periode dat de studies uit deze dissertatie plaatswonden een belangrijke wijziging ondergaan. Vanaf studiejaar 19901991 tot en met studiejaar 1994-1995 bevatte de voortgangstoets 400 vragen (studies hoofdstuk 2 en 3). Deze vragen waren verdeeld over 14 categorieën. De vragen werden aangeleverd door de verschillende vakgroepen en niet direct gerelateerd aan de inhoud van de blokken. Studenten ontvingen gerichte feedback over de categorieën waarop zij in vergelijking met hun jaargroep hoger, lager dan wel vergelijkbaar scoorden, om zo de eigen leemten in kennis te kunnen bepalen. Met ingang van studiejaar 1995-1996 bestaat elke voortgangstoets uit 600 vragen (studies hoofdstuk 4, 5 en 6), waarbij de vragen volgens een vaste verdeelsleutel zijn gekoppeld aan de verschillende programma-onderdelen zoals propedeuse, de differentiaties, methodologie $\&$ statistiek, etc. (in plaats van categorieën). De vragen worden aangeleverd door de coördinatoren van de verschillende blokken en zijn daarmee directer gekoppeld aan de inhoud van de verschillende blokken. De feedback die studenten ontvangen geeft naast inzicht in hun kennisniveau in vergelijking met de jaargroep, inzicht in het kennisniveau op de verschillende onderdelen in vergelijking met studenten uit dezelfde afstudeerrichting binnen de eigen jaargroep. Met deze wijzigingen heeft de faculteit voor studenten de herkenbaarheid van kennisontwikkeling in relatie tot het gevolgde onderwijs willen vergroten (Van Berkel, Van Til \& Sprooten, 1996; Van Berkel, 1996).

De bloktoets

De bloktoets waarmee elke blokperiode wordt afgesloten heeft betrekking op de inhoud van het aangeboden blok. Bij bloktoetsen gaat de voorkeur uit naar 'open' vormen van toetsing, zoals open vragen en het schrijven van essays. De bloktoetsen betreffen een summatieve vorm van toetsing (Zelfstudie Gezondheidswetenschappen, 1996). Elke bloktoets waarmee een blok wordt afgesloten dient met tenminste een zes (op een schaal van 1-10), in zowel de propedeuse- als de doctoraalfase, te worden afgesloten. Een bloktoetsresultaat van wijf kan worden gecompenseerd door een blokbeoordeling van minimaal een acht of twee zevens (Studiegids Gezondheidswetenschappen 1993/1994-1996/1997).

\section{Onderzoeksmodel}

Centraal in deze dissertatie staat de vraag: "in hoeverre sluit de voortgangstoets als kennistoets aan op probleemgestuurd onderwijs?" De afzonderlijke 
studies belichten specifieke aspecten van probleemgestuurd onderwijs of de voortgangstoets, welke gezamenlijk het studiegedrag van studenten beïnvloeden. Deze specifieke aspecten 'de vraagteken-optie met goed-min-fout scoring', 'aansturing van studiegedrag volgens de zevensprong', 'regelmatige voorbereiding van de onderwijsgroep' zonder 'toetsgericht studeren' uit te lokken zijn in figuur 1.2 in een onderzoeksmodel geplaatst.

Het model is als volgt te lezen. Zowel het probleemgestuurd onderwijs als voortgangstoetsing hebben een bepaalde invloed op het studiegedrag van studenten. De congruentie van het studiegedrag van de student waar met het onderwijs op aangestuurd wordt, en waar voortgangstoetsing aanleiding toe geeft, vergroot het inzicht in de aansluiting van de voortgangstoets op probleemgestuurd onderwijs.

De aansluiting van de toets op het onderwijs kan worden uitgebuit indien met het toekennen van cijfers het gewenste gedrag van studienten wordt beloond en ongewenste gedrag wordt afgestraft (Cizek, 1993). Concreet betekent dit dat datgene wat men met probleemgestuurd onderwijs voor ogen heeft moet leiden tot hogere toetsresultaten en niet gewenst toetsgericht studiegedrag wordt afgestraft. 
Probleemgestuurd onderwijs

- Studiegedrag specifiek voor probleemgestuurd onderwijs, voorkomend uit deel-nemen aan de onderwijsgroep en werken met de zevensprong beirviloed kennisverwerking (Hfst. 3)

- Aaneengeschakelde voorbereiding woor onderwijsgroep vormt de gewenste toetswoorbereiding (Hfst. 4)

\section{Voortgangstoetsing}

- Vraagvorm juist/?onjuist laat studenten de mogellijkheid wragen waarover zij geen kennis hebben zonder consequenties onbeantwoord te laten (HFst. 2) - Voortgangstoetsing geeft geen aanleiding tot toetsgericht studeren $(\mathrm{H} f \mathrm{st}$. 5)

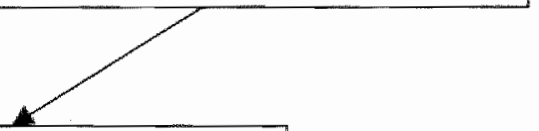

\section{Studiegedrag \& Studie-activiteiten Student}

- "Hoe' en 'wat' studenten doen in de onderwijsgroep en tijdens zelfstudie voartkomend uit probleemgestuurd onderwijs in overeenstemming met de doelstelling van het onderwijs ( $\mathrm{Hfst}$. 3)

- Regelmaat van de voorbereiding van de onderwijsgroep in een blokperiade (Htst. 4)

- Aard en ornvang van toetsgericht studiegedrag (Hfst. 5)

Figuur 1.2 Onderzoeksmodel met de veronderstellingen die aan de verschillende studies ten grondslag liggen 


\section{Vraagtekenoptie bij juist-onjuist vragen: een studie naar verschillen in gebruik en verschillen in toetsresultaten ${ }^{2}$}

In dit tweede hoofdstuk wordt een studie beschreven waarin is onderzocht in welke omvang gebruik wordt gemaakt wan de uraagtekenoptie en hoe zeker studenten zijn van vragen die zij beantwoorden. Tevens is nagegaan of bij het gebruik van de uraagtekenoptie selectieve studentengroepen in het voordeel zijn door de goed-min-fout scoring. De resultaten van de hier gepresenteerde studie zijn gebaseerd op een 'experimentele' voortgangstoets die is afgenomen onder afwijkende toetscondities, onmiddellijk na een reguliere voortgangstoets. De experimentele voortgangstoets betrof een selectie van vragen uit de eerder afgelegde voortgangstoets, waarbij de vraagtekenoptie ontbrak. Daamaast is door studenten een schatting gegeven hoe zeker zij zijn over de gegeven antwoorden. Aan dit onderzoek is deelgenomen door 248 studenten uit alle jaargroepen, na afloop van de eerste voortgangstoets van studiejaar 1993-1994.

\section{Inleiding en probleemstelling}

De 400 juist-onjuist vragen van de voortgangstoets bestrijken het gehele curriculum gezondheidswetenschappen. De onderwerpen zijn afkomstig uit alle studiejaren en alle afstudeerrichtingen, wat maakt dat het voor studenten (nagenoeg) onmogelijk is om te beschikken over kennis omtrent alle vragen. Studenten kunnen ervoor kiezen vragen onbeantwoord te laten c.q. met een vraagteken te beantwoorden. Voor de bepaling van de toetsscore vindt goed-min-fout scoring plaats om de uiteindelijke toetsscore te bepalen ('formula-scoring' in het Angelsaksische taalgebied).

2 Een gedeelte van deze studie is gepresenteerd tijdens de Onderwijs Research Dagen (ORD) te Utrecht, 1994 (Van Til \& Van Berkel, 1994) en tijdens het Gezond Onderwijs Congres (GOC-4) te Veldhoven, 1994 (Van Til \& Van Berkel., 1995) 
Zowel het gebruik van de juist-onjuist vraag als de vraagtekenoptie staan ter discussie. Veel genoemde bezwaren zijn gericht op de discussie of het mogelijk is met dit vraagtype op de juiste manier kennis te toetsen die de essentie vormt van datgene wat wordt onderwezen. Het hoofdstuk zal zich hier niet op richten. Het genoemde bezwaar waar dit hoofdstuk zich wel op richt is de hoge statistische kans op een correct antwoord door gokken. De vraag die hieruit voortkomt is of bepaalde studenten -al of niet selectief- door de gehanteerde vraagvorm en goed min fout correctie, in het voordeel zijn. Met twee antwoordmogelijkheden, juist en onjuist, is er bij blind gokken een kans van één op twee $(p=1 / 2)$ op een correct antwoord. Dit introduceert score-variantie op basis van toevalseffecten die niet gerelateerd zijn aan het kennisniveau van studenten.

Ebel (1970) verdedigt de bruikbaarheid van juist-onjuist vragen. Volgens de auteur is er namelijk een onderscheid tussen 'blind gokken' en 'geïnformeerd gokken", waarbij geïnformeerd gokken betekent dat wordt geantwoord op basis van enige kennis. Hij schrijft hierover: ${ }^{\circ} \ldots$ Blind guessing adds nothing but error to test scores, informed guesses ... provide valid indications of achievement" (pagina 387). Ebel bestrijdt het argument dat juist-onjuist vragen verschillen tussen studenten introduceert die niet gerelateerd zijn aan het kennisniveau van studenten.

Bij de voortgangstoets zijn er niet alleen verschillen tussen studenten in het aantal vragen dat $z \mathrm{ij}$ beantwoorden, maar ook in het percentage hiervan dat juist of onjuist wordt beantwoord. Onduidelijk is of variatie in de toetsresultaten, de goed-min-fout score, wordt beinvioed door verschillen in de bereidheid tot 'geïnformeerd gokken'. Hierbij is het voor de validiteit en betrouwbaarheid van de voortgangstoets van belang te achterhalen of verschillen in antwoordgedrag zijn gerelateerd aan het kennisniveau van studenten. De centrale probleemstelling luidt: "zijn er verschillen tussen studenten in de mate waarin zij bereid zijn te antwoorden en in hoeverre zijn deze (eventuele) verschillen van invloed op het resultaat op de voortgangstoets?"

\section{Achtergrond bereidheid tot antwoorden bij gesloten vragen}

Ebel (1970) nuanceert het begrip gokken bij juist-onjuist vragen door onderscheid te maken in puur gokken of antwoorden met een bepaalde hoeveelheid kennis (geïnformeerd gokken). Dit bepaalt volgens hem dat de door gokken geïntroduceerde error niet verholpen kan worden met het toepassen 
van een gokcorrectie in de scoringsformule. Hij beargumenteert dat hiermee verschillen tussen studenten worden geintroduceerd die de validiteit van de toets niet ten goede komen. Er is een groot aantal artikelen verschenen waarin diverse scoringsformules en rol van gokken bij multiple choice vragen met elkaar zijn vergeleken (bijwoorbeeld Budescu \& Bar-Hillel, 1993; Frary, 1980; Hakstian \& Kansup, 1975; Hutchinson, 1986). Theoretische modelmatige vergelijkingen brengen als probleem met zich mee dat geen rekening kan worden gehouden met de invloed die de feitelijke toetsinstructie en toetsafname hebben op het (antwoord-) gedrag van studenten.

Onderstaande onderzoeken naar het antwoordgedrag van studenten op juistonjuist vragen of multiple choice vragen bij daadwerkelijke toetsafnames illustreren een aantal factoren die van invloed zijn. Zo blijkt dat studenten die aangeven te gokken beter presteren dan op basis van kansberekening zou zijn te verwachten (Rowly \& Traub, 1977; Sherriffs \& Boomer, 1954). In het onderzoek van Rowly en Traub (1977) bijwoorbeeld is in een 80 item multiple choice toets met vier antwoordmogelijkheden aan studenten gevraagd te kiezen uit de antwoordmogelijkheden blind gokken', 'niet zeker maar het betreffende antwoord het meest waarschijnlijk vinden ten opzichte van de anderen' of 'het juiste antwoord'. Een goed antwoord leverde respectievelijk 0,1 of 2 punten op. In de categorie 'blind gokken' bleek $40.5 \%$ van de antwoorden correct ten opzichte van een volgens kansberekening verwacht percentage van $25 \%$ correct.

Dit blijkt eveneens in het onderzoek van Cross en Frary (1977), waarin studenten de instructie kregen elke vraag te beantwoorden bij enig idee over het antwoord maar niet blind te gokken. Bij het in tweede instantie beantwoorden van de eerder overgeslagen vragen blijken studenten hoger te scoren dan op basis van kansberekening verwacht mag worden. Hun bevindingen suggereren bovendien dat studenten die weinig risico nemen succesvoller zijn op eerder genegeerde items dan studenten die meer risico nemen. Grosse en Wright (1985) concluderen in hun onderzoek naar antwoordpatronen bij zeven arts-examens dat de studenten met de minste kennis het meest gokken. Volgens hen heeft dit als consequentie dat daar waar het belang van validiteit het meest gewenst is, daar waar 'onvoldoende' of 'onvoldoendetwijfel' beslissingen genomen moeten worden, deze het slechtst is. Binnen dit onderzoek is er overigens vanuit gegaan dat elk item wordt beantwoord op basis van kennis of random gokken. 
Gross (1982) suggereert bovendien in een overzichtsartikel over verschillende scoringstechnieken van meervoudige juist-onjuist vragen dat studenten een verschillende beleving hebben van hun neigen tot antwoorden op basis van gokken. Sommige studenten ervaren elk antwoord waarover zij niet absoluut zeker zijn als een gok tegenover andere studenten die antwoorden op vragen waarover zij enige mate van kennis hebben als weten (nonguess) beschouwen.

In een eerdere studie onderzocht Slakter (1968) al eens de invloed van zes verschillende antwoordinstructies, variërend in de mate waarin gokken wordt ontmoedigd, op daadwerkelijk antwoordgedrag en toetsresultaten. Uit de studie blijkt dat de neiging van gokken is te ontmoedigen door variatie in antwoordinstructie. Bovendien blijkt er variatie tussen studenten in de opvolging van antwoordinstructie, waarbij degenen zich het sterkst houden aan instructies die gokken ontmoedigen, in het nadeel zijn ten opzichte van degenen die zich hier minder aan houden. Helaas was de gehanteerde scoringsformule in deze studie niet binnen elke antwoordinstructie bij de studenten bekend.

Bovenstaande bevindingen hebben consequenties voor de validiteit van de voortgangstoets. De mogelijkheden van de antwoorden op de voortgangstoets zijn weergegeven in figuur 2.1 .

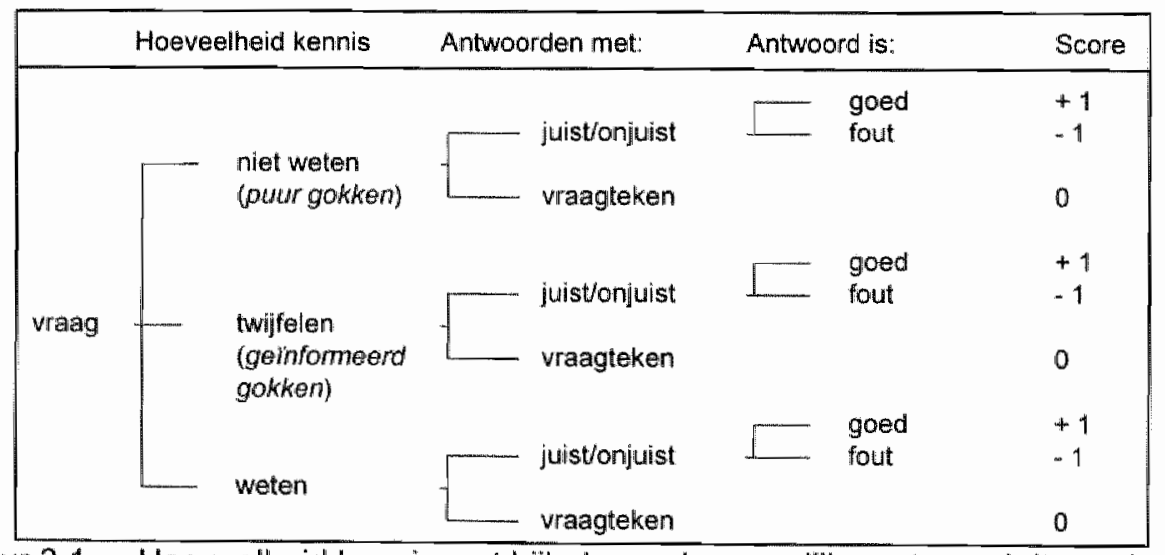

Figuur 2.1 Hoeveelheid kennis met bijbehorende mogelijke antwoordalternatieven

Wanneer studenten iets weten van het antwoord maar er niet zeker van zijn, zal een aantal de gok wagen en anderen niet. Het 'breekpunt' van het wagen van de gok ligt wellicht voor sommige studenten op een ander punt dan voor 
andere studenten. Met name in de gebieden 'niet weten' en "iets weten" kunnen verschillen optreden tussen studenten in het al dan niet beantwoorden van de vragen.

\section{Vraagstellingen en veronderstellingen}

De eerder vermelde probleemstelling "zijn er verschillen tussen studenten in de mate waarin zij gokken en in hoeverre zijn deze (eventuele) verschillen van invloed op het resultaat op de voortgangstoets? ? $^{\text {s }}$ valt uiteen in een aantal vraagstellingen. De context van onderstaande vraagstellingen zal eveneens worden weergegeven.

De voortgangstoets bij de Faculteit der Gezondheidswetenschappen bevat vragen die het kennisdomein van alle afstudeerrichtingen bestrijken. Dit maakt dat studenten over een groot gedeelte van de vragen geen kennis hebben. Veelal bevinden zij zich nog niet aan het einde van hun studie en bovendien volgen zij slechts ëen van de zeven afstudeerrichtingen. Het gedeelte van de toets waarover studenten kennis hebben (of menen te hebben), blijkend uit het aantal vragen dat wordt beantwoord is onderwerp van de eerste vraagstelling.

1. In welke mate wordt gebruik gemaakt van de vraagtekenoptie?

Bij het beantwoorden van een vraag is er echter geen sprake van een absolute tweedeling tussen weten en niet weten (Ebel, 1970). Hierbij is het belangrijk te weten welk antwoordgedrag studenten vertonen in het tussengebied 'een vermoeden hebben' en hoeveel vragen correct worden beantwoord met een verschillende mate van 'een vermoeden hebben'. Dit staat centraal in de volgende vraagstelling.

2. Hoe zeker zijn studenten van antwoorden op vragen die worden beantwoord met juist/onjuist of met het vraagteken en welk percentage is hiervan correct bij een verschillende mate van zekerheid?

De veronderstelling is dat wanneer studenten met grotere mate van zekerheid antwoorden de fractie correcte antwoorden toeneemt.

De vraagtekenoptie komt voort uit het gegeven dat studenten niet bij alle vragen over kennis beschikken. Goed-min-fout scoring wordt toegepast om te voorkomen dat studenten blind gaan gokken. In eerder onderzoek is gebleken dat studenten beter presteren dan op basis van kansberekening valt te verwachten, op vragen waarbij zij aangeven puur te gokken (Cross \& Frary, 1977; Rowly \& Traub, 1977; Sherriffs \& Boomer, 1954). Cross en Frary 
(1977) suggereren bovendien dat studenten die tijdens de toets weinig risico nemen succesvoller zijn op de items die zij 'blind gokken' dan studenten die meer risico nemen. Wat betreft de voortgangstoets is het van belang te weten of deze veronderstelling ook geldt voor vragen waarover enige kennis aanwezig is, het antwoordgebied 'iets weten/een vermoeden hebben' (zie figuur 2.1). Bij de huidige scoringswijze van de voortgangstoets zou dit ongewenste verschillen tussen studenten in de goed-min-fout score opleveren. Sommige studenten zullen in dit antwoordgebied kiezen voor de vraagtekenoptie, andere studenten zullen het risico van correctie voor fouten nemen en meer neigen naar antwoorden met juist/onjuist. De relatie tussen verschillen in gebruikmaking van de vraagtekenoptie en toetsresultaten staan centraal in de volgende vraagstelling.

3. Wat is de relatie tussen de mate waarin studenten risico's nemen en hun voortgangstoetsresultaten?

Uitgaande van de suggestie van Cross en Frary (1977) kan de volgende hypothese worden opgesteld: studenten die minder risico nemen zullen een hoger percentage vragen die met een vraagteken zijn beantwoord correct beantwoorden, wanneer deze vragen alsnog met juist of onjuist (in tweede instantiej beantwoord dienen te worden.

Grosse en Wright (1985) veronderstellen dat de studenten met de minste kennis het meest gokken. Volgens deze onderzoekers resulteert dit in lagere validiteit daar waar deze het meest is gewenst. Bij studenten met minder kennis is in hogere mate sprake van error variantie die niet gerelateerd is aan de kennis waarover een persoon beschikt. Grosse en Wright (1985) gaan bij deze veronderstelling uit van juist-onjuist vragen zonder gebruikmaking van een vraagtekenoptie en negeren de mogelijkheid een vraag met partiële kennis te beantwoorden. In hoeverre bij de voortgangstoets ook geldt dat studenten met minder kennis op een groter aantal vragen gokken, met de aanwezigheid van een vraagtekenoptie, wordt nagegaan in de volgende vraagstelling.

4. Is er een relatie tussen het kennisniveau van een student en het aandeel correcte antwoorden op vragen die eerder met het vraagteken zijn beantwoord?

Op groepsniveau zal meer gokken consequenties hebben woor het percentage correcte antwoorden op de eerder genegeerde items. Indien geldt dat studenten met de minste kennis het meeste gokken, dan betekent dit dat deze 
studenten met de huidige (goed-min-fout) scoring een lager percentage correcte antwoorden hebben op eerder genegeerde items, in vergelijking met de studenten met een hoger kennisniveau.

Naast verschillen in gokbereidheid zijn volgens Gross (1982) inschattingsverschillen een volgend argument tegen het gebruik van een gokcorrecties ter ontmoediging van gokgedrag. Studenten kunnen volgens hem een verschil in beleving hebben in wat geldt als antwoorden op basis van weten of antwoorden op basis van gokken (Gross, 1982). In hoeverre dit opgaat woor de voortgangstoets is onderwerp van de vijfde vraagstelling.

5. Zijn er verschillen in de inschatting van studenten omtrent de mate waarin zij zeker zijn van een antwoord en het kennisniveau?

Voor de voortgangstoets betekent dit dat studenten met vergelijkbare kennis beschouwd als een vergelijkbare toetsscore met vergelijkbare inschatting van de juistheid van antwoorden, een verschillend aandeel correcte antwoorden hebben. De aanname dat de voortgangstoets niet selectief bepaalde studenten bevoordeelt door het gebruik van de vraagtekenoptie is juist indien er geen verschil blijkt in het aandeel correcte antwoorden bij een vergelijkbare inschatting van de juistheid van de antwoorden.

\section{Methode}

\section{Procedure}

De gegevens voor het onderzoek zijn in twee gedeelten verzameld. Het eerste deel van het onderzoek betreft een regulliere voortgangstoets met studieconsequenties. Deze toets is gemaakt door in principe alle studenten Gezond heidswetenschappen van studiejaar 1993-1994 $(\mathrm{n}=1553)$. Het tweede deel van het onderzoek bestaat uit eer herhaling van onderdelen van de reguliere toets onder afwijkende toetscondities en heeft aansluitend aan de reguliere toets plaats gevonden. De "tweede' toets wordt in de verdere tekst aangeduid als experimentele voortgangstoets.

Ondanks het gevaar van verlies aan concentratie is gekozen voor onmiddellijke afname na de reguliere toets. Bij toetsing op een later tijdstip zouden de antwoorden inmiddels bekend zijn. Om de effecten van concentratieverlies te minimaliseren is de toetslengte verkort en hebben studenten slechts een selectie van vragen opnieuw ter beantwoording gekregen. Het invullen van de 


\section{Hoofdetuk 2}

reguliere voortgangstoets heeft gemiddeld ongeveer twee uur in besilag genomen ten opzichte van gemiddeld ëen uur voor het invullen van de experimentele voortgangstoets.

\section{Populatie}

De reguliere voortgangstoets is afgenomen bij 1305 studenten Gezondheidswetenschappen. Door 248 van deze studenten is op basis van vrijwilligheid tegen een financiële vergoeding deelgenomen aan de experimentele voortgangstoets. In tabel 2.1 staat het aantal studenten weergegeven, uitgesplitst naar jaargroep, dat aan het experiment heeft deelgenomen.

Tabel 2.1 Verdeling deelnemers aan reguliere voortgangstoets en experimentele voortgangstoets over de jaargroepen

\begin{tabular}{lccc}
\hline & $\begin{array}{c}\text { Reguliere toets } \\
(\mathrm{N}=7305)\end{array}$ & $\begin{array}{c}\text { Experimentele } \\
\text { toets }(\mathrm{N}=248)\end{array}$ & $\begin{array}{c}\% \text { van populatie } \\
(19.0 \%)\end{array}$ \\
\cline { 2 - 4 } jaargroep 1 & 199 & 78 & 39.2 \\
jaargroep 2 & 373 & 71 & 19.0 \\
jaargroep 3 & 352 & 62 & 17.6 \\
jaargroep 4 & 381 & 37 & 9.7 \\
\hline
\end{tabular}

De deelname van studenten uit verschillende jaargroepen is niet evenredig verdeeld naar hun omvang. Er is sprake van een oververtegenwoordiging van eerstejaars en een ondervertegenwoordiging van vierdejaars studenten. Op relevante onderdelen, zoals vergelijking van groepen op basis van toetsscores, wordt hier in de analyses rekening mee gehouden. Tevens is sprake van enige selectiviteit in voortgangstoetsresultaten tussen studenten die wel en niet hebben deelgenomen aan de experimentele voortgangstoets (zie bijlage 1). Studenten die hebben deelgenomen aan de experimentele voortgangstoets hebben in alle jaargroepen op de reguliere voortgangstoets hogere goed-minfout scores behaald, maar alleen bij de vierdejaars studenten zijn deze verschillen significant $(\mathbb{F}(416,1)=15.846, \mathrm{p} \leq 0.001)$. Bij de interpretatie van de resultaten zal hier rekening mee worden gehouden. 


\section{Materialen}

\section{Reguliere voortgangstoets}

De reguliere voortgangstoets bevat 400 vragen. De vragen zijn ingedeeld in veertien categorieën; vijf algemene categorië̈n en negen stroomspecifieke categoriën. De vijf algemene categorieën betreffen algemeen gezondheidswetenschappelijke kennis, zoals de categorieën epidemiologie en informatica \& statistiek. De negen stroomspecifieke categorieën zijn meer afstudeerrichting gebonden, zoals de categorieën verplegingswetenschap en economie.

De vragen zijn van het type juist - onjuist met vraagtekenoptie. Ter correctie voor gokken wordt de eindscore van studenten bepaald door het aantal goede antwoorden te verminderen met het aantal foutieve antwoorden.

\section{Experimentele voortgangstoets}

De experimentele voortgangstoets bestaat uit een selectie van de juist-onjuist vragen uit de eerder afgeronde voortgangstoets. Bij de experimentele voortgangstoets ontbreekt de vraagteken-optie. De studenten hebben de nadrukkelijke instructie gekregen alle vragen te beantwoorden, zelfs wanneer zij het antwoord niet wisten. Tevens hebben zij op een vijfpuntsschaal een aanduiding gegeven over hoe zeker zij zijn van het antwoord, met de volgende opties: (1) pure gok, (2) rond $25 \%$ zeker, (3) rond $50 \%$ zeker, (4) rond $75 \%$ zeker en (5) (nagenoeg) $100 \%$ zeker. Deze antwoorden worden verder aang eduid als zekerheidsaanduiding. In tabel 2.2 is samengevat welke variabelen zijn verzameld op de twee toetsmomenten.

Tabel 2.2 Verzamelde onderzoeksvariabelen tijdens de voortgangstoets en experimentele voortgangstoets

\begin{tabular}{|c|c|}
\hline Voontgangstoets & Experimentele voortgiangstoets \\
\hline $\begin{array}{l}\text { - } 400 \text { vragen } \\
\text { - beantwoord met mogelijkheid "juist/r/onjuist' }\end{array}$ & $\begin{array}{l}\text { - selectie van vragen wit woortgangstoets } \\
\text { - beantwoord met magellikheid "juist/onjuist" } \\
\text { - markering met } 0 \% / 25 \% / 50 \% / 75 \% / 100\end{array}$ \\
\hline $\begin{array}{l}\text { gemiddelde zekerheid van markering (tijdens ex- } \\
\text { permentele voortgangstoets) woor Juistonjuist } \\
\text { andwoorden (tjdens reguliere voortgangstoets) }\end{array}$ & $\begin{array}{l}\text { \% zoker } \\
\text { - gemiddelde zekerheid wan markering woor vra- } \\
\text { gen eerder met? beantwoord }\end{array}$ \\
\hline $\begin{array}{l}\text { Her is gebruk gemaakt van de selectie van vragen } \\
\text { die tewens zijn afgenomen bif de experimentele } \\
\text { woortgangstoets }\end{array}$ & $\begin{array}{l}\text { Alleen de wagen die eerder met "? "zijn beant- } \\
\text { woord maken onderdeel uit van de experimentele } \\
\text { scores }\end{array}$ \\
\hline
\end{tabular}


Er is gebruik gemaakt van vier toetsversies, bepaald op basis van de afstudeervariant die de studenten volgden; een versie voor de studenten uit de propedeuse en voor studenten uit elk van de drie stromen een versie (biologische, gedrags- en maatschappij stroom). Elke variant bevatte de vijf algemene vraagcategorieên en daarnaast de aan de stroom gerelateerde categorieën. In de versie voor de propedeuse is, naast de algemene categorieën, uit elke stroom een specifieke categorie geselecteerd. De vier versies van de experimentele voortgangstoets bevatten 188 tot 233 vragen. De moeilijkheidsgraad van de verschillende versies van de experimentele voortgangstoets zijn redelijk vergelijkbaar, hoewel de scores op de maatschappij-variant iets lager liggen. De goed-min-fout scores van de doctoraal studenten (als geheel) zijn vergelijkbaar (geen significante verschillen). Bij vergelijking van de varianten binnen de jaargroepen hebben de vierdejaars uit de maatschappijstroom de laagste goed-min-fout score behaald $(\mathrm{F}(35,2)=4.173, \mathrm{P} \leq 0.05$; zie bijlage 1 , tabel 2).

\section{Analyse}

In alle analyses is gestandaardiseerd voor verschil in toetslengte, door het aantal vragen te transformeren naar 233 vragen. Voor de berekening van de test-hertest betrouwbaarheid zijn de non-parametrische correlaties berekend tussen de tijdens de reguliere en de experimentele voortgangstoets gegeven antwoorden. De berekening van de correlaties is non-parametrisch gedaan omdat een item alleen in de berekening is betrokken wanneer een student deze zowel tijdens de reguliere als tijdens de experimentele toets heeft beantwoord (met goed of fout; vraagtekens zijn per definitie anders beantwoord, en daarom niet meegenomen in de berekening, omdat deze antwoordmogelijkheid ontbreekt in de experimentele toets). Voor elk item is apart een correlatie berekend voor elk van de vijf niveaus van mate van zekerheid; voor elk van de 400 items levert dit dus vijf correlaties. Over de 400 correlaties per mate van zekerheid is vervolgens de mediaan ${ }^{3}$ van de correlaties berekend, in plaats van een gemiddelde. Voor de berekening van een gemiddelde worden gegevens op intervalniveau verondersteld, hetgeen bij een afstand tussen correlaties niet het geval is. Deze test-hertest betrouwbaarheid op de vijf medianen vormt een indicatie voor de betrouwbaarheid van de antwoorden

\footnotetext{
${ }^{3}$ De mediaan wan de correlaties bij een bepalde mate van zekerheid is de middelste correlatie van de $400^{3}$ correlaties
} 
op de vragen die tijdens de reguliere voortgangstoets met het vraagteken zijn beantwoord.

Ter beantwoording van vraagstellingen over het gebruik van het vraagteken is gebruik gemaakt van beschrijvende statistiek. Voor het in kaart brengen van verschillen in antwoordgedrag en toetsresultaten is gebruik gemaakt van groepsvergelijkingen waarbij verschillen zijn getoetst met behulp van een ANOVA. Deze groepsvergelijkingen zijn gemaakt op basis van risico bereidheid'en 'kennis'.

Als indicatie voor 'risico bereidheid' is gebruik gemaakt van de gemiddelde zekerheidsaanduiding op de vragen die met juist/onjuist zijn beantwoord tijdens de reguliere voortgangstoets. Bij deze keuze is er vanuit gegaan dat studenten die veel risico nemen eerder zullen besluiten te antwoorden. Dit veronderstelt dat zij antwoorden met een lagere zekerheid dan studenten die voorzichtiger zijn.

(on)Zekerheid en neiging tot antwoorden worden daarnaast beïnvloed door de hoeveelheid kennis waarover studenten beschikken. Hiervoor is een correctie toegepast door gebruik te maken van de individuele afwijking ten opzichte van de groep (het residu) op de gemiddelde zekerheid bij zijn of haar kennisniveau. Bij het op groepsniveau verklaren van de gemiddelde zekerheid door het kennisniveau vormt het residu (persoonsgebonden) een indicatie voor de risicobereidheid van een individuele student. De gemiddelde zekerheidsaanduiding van een individuele student wordt verminderd met het residu van de veronderstelde zekerheidsaanduiding bij zijn kennisniveau $\llbracket 1$ - gemiddelde zekerheid $=$ residu - $a^{*}$ goed-min-fout score). Het residu is omgecodeerd en omgerekend tot een percentielscore; de variabele heeft een waarde tussen de 0 - 100, waarbij een lage waarde staat voor een student die weinig risico neemt en een hoge waarde voor een student die veel risico neemt.

Als indicatie voor 'kennisniveau' is gebruik gemaakt van de oorspronkelijke goed-min-fout score op de voortgangstoets.

Bij de beantwoording van de vraagstellingen omtrent de invloed van 'risico nemen' en 'kennisniveau" zijn studenten in drie groepen ingedeeld; $33.3 \%$ studenten met de hoogste waarde op de variabele, de $33.3 \%$ middelste studenten en de $33.3 \%$ studenten met de laagste waarden. Om jaargroepeffecten te voorkomen zijn studenten voor zowel 'risico nemen' als 'kennisniveau' gegroepeerd binnen jaargroepen. 


\section{Resultaten}

\section{Betrouwbaarheid van de antwoorden tijdens de experimentele voortgangstoets}

In tabel 2.3 wordt de mediaan van de 400 correlaties tussen het antwoord op deze 400 items tijdens de reguliere toetsen en het antwoord tijdens de experimentele toets gegeven, afzonderlijk berekend over de verschillende maten van zekerheid.

Tabel 2.3 Mediaan van de correlatie tussen de antwoorden op de items die tijdens de reguliere en experimentele voortgangstoets zijn gegeven

\begin{tabular}{lcc} 
& mediane correlatie & aantal geldige items \\
\cline { 2 - 3 } $0 \%$ zeker & 0.802 & 3 \\
$25 \%$ zeker & 0.810 & 53 \\
$50 \%$ zeker & 0.900 & 163 \\
$75 \%$ zeker & 0.881 & 198 \\
zeker & 1.000 & 104 \\
\hline
\end{tabular}

NB een item is als geldig beschouwd indien 5 of meer studenten dit item met betreffende zekerheid, zowel tijdens de voortgangstoets als tijdens het experiment, hebben beantwoord

De mediaan is bij elke mate van zekerheid hoog, zeker voor de antwoorden op vragen die zijn beantwoord met een hoge mate van kennis. Het antwoord dat op het eerste meetmoment wordt gegeven is veelal gelijk aan het antwoord dat op het tweede meetmoment is gegeven, zelfs voor vragen die zijn beantwoord met een lage mate van zekerheid.

\section{Gebruik vraagtekenoptie en mate van zekerheid van de antwoorden}

In tabel 2.4 wordt een volledig overzicht gegeven van de antwoorden die gegeven zijn tijdens zowel de reguliere als de experimentele voortgangstoets. In de tabel vindt een steeds verdere specificatie van de aard van de antwoorden plaats. In kolom 1 wordt weergegeven op basis van welke mate van zekerheid de antwoorden zijn gegeven. In de tweede kolom wordt vermeld of deze vragen tijdens de reguliere voortgangstoets met juist/onjuist of met het vraagteken zijn beantwoord. Hoeveel vragen daarvan goed dan wel fout zijn beantwoord wordt in de derde kolom weergegeven. Bij elk van de drie kolommen worden zowel de absolute aantallen als de percentages gegeven, waarbij de totalen van de kolommen telkens uitkomen op 233 vragen of $100 \%$. 
Tabel 2.4 Absoluut en percentage vragen dat al of niet, goed dan wel fout, is beantwoord met een bepaalde zekerheid (met standaarddeviatie tussen haakjes)

\begin{tabular}{|c|c|c|c|c|c|c|c|c|}
\hline \multicolumn{3}{|c|}{ hoeveelheid kennis } & \multicolumn{3}{|c|}{ antwoorden met juist/onjuist of? } & \multicolumn{3}{|c|}{ antwoord } \\
\hline & abs & $\%$ & & abs & $\%$ & & abs & $\%$ \\
\hline \multirow[t]{4}{*}{$0 \%$ zeker } & 92.6 & 39.7 & juistronjuist & $4.2(11,4)$ & $1.8(4.9)$ & goed & $2.4(6.3)$ & $1.0(2.7)$ \\
\hline & $(37.5)$ & $(16.1)$ & & & & fout & $1.8(5.3)$ & $0.8(2.3)$ \\
\hline & & & vraagteken & $88.4(39.0)$ & $37.9(16.7)$ & goed & $45.4(20.7)$ & $19.5(8.9)$ \\
\hline & & & & & & fout & $43.0(19.5)$ & $18.4(8.4)$ \\
\hline \multirow[t]{4}{*}{$25 \%$ zeker } & 43.7 & 18.8 & juist/onjuist & $9.3(13.4)$ & $4.0(5.8)$ & goed & $5.5(7.9)$ & $2.3(3.4)$ \\
\hline & $(17,4)$ & $(7.5)$ & & & & fout & $3.9(6.0)$ & $1.7(2.6)$ \\
\hline & & & vraagteken & $34.3(17.4)$ & $14.7(7.5)$ & goed & $19.2(10.3)$ & $8.2(4.4)$ \\
\hline & & & & & & fout & $15.2(8.3)$ & $6.5(3.6)$ \\
\hline \multirow[t]{4}{*}{$50 \%$ zeker } & 38.6 & 16.5 & juist/onjuist & $19.9(15.3)$ & $8.5(6.6)$ & goed & $12.6(10.1)$ & $5.4(4.3)$ \\
\hline & $(16.7)$ & $(7.1)$ & & & & fout & $7.3(6.2)$ & $3.1(2.6)$ \\
\hline & & & vraagteken & $18.7(14.1)$ & $8.0(6.1)$ & goed & $10.5(8.3)$ & $4.5(3.6)$ \\
\hline & & & & & & fout & $8.7(6.5)$ & $3.5(2.8)$ \\
\hline \multirow[t]{4}{*}{$75 \%$ zeker } & 35.1 & 15.1 & juist/onjuist & $29.6(16.5)$ & $12.7(7.1)$ & goed & $20.8(11,8)$ & $8.9(5.1)$ \\
\hline & $(17.4)$ & $(7.5)$ & & & & fout & $8.8(6.2)$ & $3.8(2.7)$ \\
\hline & & & wraagteken & $5.6(7.1)$ & $2.4(3.1)$ & goed & $3.3(4.2)$ & $1.4(1.8)$ \\
\hline & & & & & & fout & $2.2(3.3)$ & $1.0(1.4)$ \\
\hline \multirow[t]{4}{*}{ zeker } & 23.1 & 9.9 & juist/onjuist & $22.2(16.0)$ & $9.5(6.9)$ & goed & $18.7(12.5)$ & $8.0(5.4)$ \\
\hline & $(16.7)$ & $(7.2)$ & & & & fout & $3.5(4.5)$ & $1.5(1.9)$ \\
\hline & & & vraagteken & $0.8(1.9)$ & $0.4(0.8)$ & goed & $0.6(1.3)$ & $0.2(0.5)$ \\
\hline & & & & & & fout & $0.3(0.9)$ & $0.1(0.4)$ \\
\hline \multirow[t]{4}{*}{ totaal } & 233.0 & 100.0 & juist/onjuist & $85.2(44.0)$ & $36.6(18.9)$ & goed & $59.9(28.7)$ & $25.7(12.3)$ \\
\hline & & & & & & fout & $25.3(17.2)$ & $10.9(7.4)$ \\
\hline & & & vraagteken & $147.8(44.0)$ & $63.4(18.9)$ & goed & $78.9(24.2)$ & $33.8(10.4)$ \\
\hline & & & & & & fout & $68.8(21.9)$ & $29.5(9.4)$ \\
\hline
\end{tabular}

Tijdens de reguliere voortgangstoels zijh alle vragen beantwoord met juist, onjuist of vraagteken. De mate van zekerheid van deze antwoorden is tijdens de experimentele voortgangstoets gegeven. De vragen die tijdens de reguliere toets met juist en onjuist zijn beantwoord zijm nogmaals beantwoord tijdens de experimentele toets, waarbij de originele antwoorden zijn gebruikt voor de bepaling van het aantal carrecte antwoorden.

De mate van zekerheid van de antwoorden indiceert bij welk percentage zeker er gebruik wordt gemaakt van het vraagteken. Over $39.7 \%$ van de vragen geven studenten aan geen kennis te beschikken (eerste rij). Het gedeelte van de vragen waarover studenten meer kennis denken te hebben neemt af; $18.8 \%$ van de vragen betreft ongeveer $25 \%$ zeker, afnemend tot. slechts $9.9 \%$ van de vragen waarbij studenten aangeven $100 \%$ zeker te zijn 
van het antwoord. Antwoord op de vraag in welke mate er gebruik wordt gemaakt van de vraagtekenoptie is te vinden in de onderste rij, de rij 'totaal'. Ruim $63 \%$ van de wragen wordt met een vraagteken beantwoord, de overige vragen worden met juist of onjuist beantwoord.

De tweede kolom van de vijf rijen '0 \% zeker' tot en met ' $100 \%$ zeker' geeft informatie over de mate van zekerheid van studenten bij het al of niet beantwoorden van vragen. Van alle vragen wordt slechts $1.8 \%$ puur gegokt. Ook het aandeel vragen dat met slechts $25 \%$ zeker wordt beantwoord is klein (4.0\%). Bij $50 \%$ zeker (16.5\% van de vragen) ligt het aandeel van de vragen dat wordt beantwoord $(8.5 \%)$ en het aandeel van de vragen dat niet worden beantwoord $(8.0 \%)$ ongeveer gelij $\mathrm{k}$. In overeenstemming met de verwachting worden bij toenemende zekerheid in de meeste gevallen de vragen beantwoord. Slechts $2.4 \%$ vragen met ' $75 \%$ zeker' en $0.4 \%$ vragen met 'zeker' zijn onbeantwoord gelaten.

In de derde kolom staat het aantal en percentage correcte antwoorden. De juist en onjuist antwoorden die tijdens de experimentele voortgangstoets zijn gegeven verschaffen inzicht in de kennis van studenten. Bij elke mate van (on)zekerheid, voor zowel de reguliere als de experimentele voortgangstoets, geldt dat meer vragen goed dan fout worden beantwoord.

In tabel 2.5 wordt gepresenteerd hoeveel procent van de vragen die met een bepaalde mate van zekerheid zijn beantwoord correct zijn beantwoord.

Tabel 2.5 Percentage vragen en correcte antwoorden met verschillende mate van zekerheid met percentage correct volgens kansberekening, uitgesplitst naar reguliere en experimentele voortgangstoets

\begin{tabular}{lccccc}
\hline & \multicolumn{2}{c}{$\%$ correct beantwoord } & \multicolumn{2}{c}{ fractie van beantwoorde vragien $^{*}$} \\
\cline { 2 - 6 } & tijdens VGT & tijdens experiment & volgens kans & tolaal & beantwoord tijdens VGT \\
\cline { 2 - 6 } $0 \%$ zeker & 57.1 & 51.4 & 50.0 & 39.7 & 4.5 \\
$25 \%$ zeker & 59.1 & 56.0 & 62.5 & 18.8 & 21.3 \\
$50 \%$ zeker & 63.3 & 56.1 & 75.0 & 16.5 & 5.1 .6 \\
$75 \%$ zeker & 70.3 & 58.9 & 87.5 & 15.1 & 84.3 \\
zeker & 84.2 & 66.7 & 100.0 & 9.9 & 96.1 \\
van de totale toets zijn studenten over 39.7\% total onzeker. Hiervan wordit $4.5 \%$ toch met juistronjuist \\
beantwoord en wordt de overige $95.5 \%$ dus met vraagteken beantwoord
\end{tabular}

In deze tabel is onderscheid gemaakt tussen de vragen die zijn beantwoord tijdens de reguliere en de experimentele voortgangstoets. Om deze percenta- 
ges binnen een kader te plaatsen wordt in de tabel tevens aangegeven hoeveel procent op basis van kansberekening correct zou zijn en op hoeveel procent van de totale toets de percentages betrekking hebben. Bij puur gokken wordt aangenomen dat de statistische kans op een correct antwoord $50 \%$ (een kans van 1 op 2). Bij $25 \%$ zeker is deze kans $62.5 \%$, namelijk 25 $\%$ is correct vanwege kennis waarbij opgeteld de helft van de overige $75 \%$ op basis van goed gokken.

De hoeveelheid correct beantwoorde vragen is alleen bij de vragen waarover geen kennis aanwezig is, hoger dan op basis van kansberekening verwacht wordt. In de overige gevallen ligt het percentage correct beneden de verwachte hoeveelheid, maar blijft het rendement per saldo positief (meer goed dan fout).

Bij het toenemen van de mate van zekerheid loopt ook het percentage correcte antwoorden op, van 57.1 tot $84.2 \%$ bij de reguliere toets, in vergelijking tot een percentage correct van 51.4 tot $66.7 \%$ voor vragen die toen met het vraagteken zijn beantwoord.

\section{Risico nemen en resultaten op de voortgangstoets}

Als indicatie voor de mate waarin studenten risico nemen, zijn zij op basis van de gemiddelde zekerheidsaanduidingen voor hun juist/onjuist antwoorden op de reguliere voortgangstoets ingedeeld in drie groepen (zie analyse). In tabel 2.6 is voor elk van de drie groepen weergegeven hoeveel procent van de antwoorden per zekerheidsaanduiding correct is beantwoord. In de onderste rij wordt vermeld in welke goed-min-fout score dit heeft geresulteerd. Om de percentages op hun waarde te kunnen schatten wordt telkens tussen haakjes vermeld hoeveel procent het betreft van de in totaal 233 vragen.

Tabel 2.6 Gemiddeld percentage correcte antwoorden van tijdens de voortgangstoets met juist/onjuist beantwoorde vragen (fractie van alle 233 vragen)

\begin{tabular}{|c|c|c|c|c|c|c|c|}
\hline \multirow[b]{2}{*}{$0 \%$ zeker } & \multicolumn{2}{|c|}{ minste risico } & \multicolumn{2}{|c|}{ gem. risico } & \multicolumn{2}{|c|}{ meeste fisico } & \multirow{2}{*}{$\frac{\text { F-waarde }}{0.220 \mathrm{~ns}}$} \\
\hline & 56.04 & $(0.3)$ & 59.37 & (0.5) & 61.48 & $(4.6)$ & \\
\hline $25 \%$ zeker & 56.44 & $(0.7)$ & 60.71 & $(2.5)$ & 60.31 & $(8.8)$ & $0.386 \mathrm{~ms}$ \\
\hline $50 \%$ zeker & 62.27 & $(3.5)$ & 61.73 & $(8.7)$ & 66.46 & $(13.3)$ & $1.998 \mathrm{~ns}$ \\
\hline $75 \%$ zeker & 68.02 & $(11.4)$ & 71.15 & $(14.1)$ & 7261 & $(12.6)$ & $2.275 \mathrm{~ns}$ \\
\hline zeker & 84.04 & $(13.5)$ & 87.41 & $(9.0)$ & 89.45 & $(6.1)$ & $4.582^{* *}$ \\
\hline Gminf-score & 39.86 & $(29.5)$ & 44.28 & $(34.8)$ & 48.31 & $(45.4)$ & $3.471^{*}$ \\
\hline
\end{tabular}

nsp $p>0.05 ; * 0.0 .05 ; * * 0.01$ 
De groep studenten die het meeste risico neemt heeft in de meeste gevallen het hoogste percentage goede antwoorden gegeven bij een bepaalde zekerheidsaanduiding. Alleen de vragen die met '25\% zeker" zijn beantwoord vormen hier een uitzondering op. De middelste groep heeft ten opzichte van de groep die het minste risico neemt veelal een hoger percentage goede antwoorden, met uitzondering van de vragen die met '50\% zeker' zijn beantwoord. De verschillen zijn bij de vragen beantwoord met 'zeker' bovendien significant. Ten opzichte van de groep die het meeste risico neemt zijn er nauwelijks verschillen.

Een aantal opmerkingen over het aandeel vragen dat met juist/onjuist is beantwoord door de verschillende groepen (de getallen tussen haakjes) dient bij bovenstaande bevinding te worden geplaatst. Zoals te verwachten beantwoordt de groep studenten die het meeste risico neemt de meeste vragen $(45.4 \%)$ en de studenten die het minste risico nemen de minste $(29.5 \%)$. Deze verschillen zijn bovendien significant ( $F(245,2) 17.15, p \leq 0.001)$. Echter, studenten die het minste risico nemen beantwoorden daarvan de meeste vragen in de categorie 'zeker', in afwijking van de studenten met gemiddeld risico die de meeste vragen beantwoorden in de categorie ' $75 \%$ zeker' en studenten die het meeste risico nemen in de categorie '50\% zeker'. Hierbij geldt dat de rendementscijfers, het percentage correcte antwoorden, voor de categorie 'zeker' beduidend hoger zijn dan voor de categorie '50 \% zeker'.

Wanneer de uiteindelijke goed-min-fout score van de drie groepen met elkaar wordt vergeleken blijkt de groep studenten die het meeste risico neemt de beste resultaten te behalen op de voortgangstoets, echter het verschil is niet significant.

Het verschil in het percentage correcte antwoorden ten gevolge van variatie in risico nemen op vragen die in eerste instantie met vraagteken zijn beantwoord (met een bepaalde mate van zekerheid) is weergegeven in tabel 2.7 . 
Tabel 2.7 Gemiddelde percentages correcte antwoorden op vragen die met het vraagteken zijn beantwoord per groep mate van risico nemen (fractie van alle 233 vragen)

\begin{tabular}{|c|c|c|c|c|c|c|c|}
\hline \multirow[b]{2}{*}{$0 \%$ zeker } & \multicolumn{2}{|c|}{ minste risico } & \multicolumn{2}{|c|}{ gem. risico } & \multicolumn{2}{|c|}{ meeste risico } & \multirow{2}{*}{$\begin{array}{l}\text { F-waande } \\
0.086 \mathrm{~ns}\end{array}$} \\
\hline & 51.31 & $(38.5)$ & 51.15 & $(38.8)$ & 51.58 & $(36.5)$ & \\
\hline $25 \%$ zeker & 54.83 & $(15.4)$ & 54.82 & $(16.3)$ & 57.47 & $(12.5)$ & $0.795 \mathrm{~ns}$ \\
\hline $50 \%$ zeker & 57.21 & $(11.8)$ & 53.53 & $(8.0)$ & 58.05 & $(4.3)$ & $1.551 \mathrm{~ms}$ \\
\hline $75 \%$ zeker & 60.65 & $(4.1)$ & 59.38 & (1.9) & 62.40 & $(1.1)$ & $0.141 \mathrm{~ns}$ \\
\hline zeker & 64.78 & $(0.6)$ & 56.59 & $(0.3)$ & 63.89 & $(0.3)$ & $0.309 \mathrm{~ns}$ \\
\hline GminF-score & 7.36 & $(70.5)$ & 5.87 & $(65.2)$ & 7.09 & $(54.6)$ & $0.533 \mathrm{~ns}$ \\
\hline
\end{tabular}

$\overline{\mathrm{nsp}}>0.05$

Op de vragen die tijdens de voortgangstoets met een vraagteken zijn beantwoord blijken slechts marginale, niet significante verschillen in het aandeel vragen dat correct wordt beantwoord met een bepaalde mate van zekerheid. Voor deze vragen geldt dus niet dat de groep studenten die het meeste risico neemt een van de andere groepen afwijkend aandeel correcte antwoorden heeft. Met grote voorzichtigheid kan eerder worden opgemerkt dat de 'middengroep' wat betreft mate van risico nemen tendeert naar een lager aandeel correcte antwoorden bij de verschillende mates van zekerheid. Deze 'suggestie' is het duidelijkst zichtbaar bij de categorieën '50\% zeker' en 'zeker'. Deze groep heeft ook de laagste goed-min-fout score op de vragen die tijdens de voortgangstoets met een vraagteken zijn beantwoord.

Er is geen significant verschil bij 'zeker' tussen de groep studenten die het meeste en de groep die het minste risico nemen ten gunste van de studenten die het meeste risico nemen bij de vragen die met vraagteken zijn beantwoord. Dit is een ondersteuning voor de conclusie dat de studenten die het meeste risico nemen hun kennis het sterkst onderschatten.

\section{Kennisniveau en aandeel correcte antwoorden op eerder genegeerde vragen}

op basis van de kennis die studenten menen te hebben over een vraag besluiten zij al of niet te antwoorden. Andere factoren die een rol spelen bij het beantwoorden van vragen, mogen geen invloed hebben op de voortgangstoetsresultaten.

In tabel 2.8 wordt de variatie in het percentage vragen dat wordt beantwoord tijdens de voortgangstoets (met een bepaalde mate van zekerheid) bij studenten met verschillend kennisniveau weergegeven. 
Tabel 2.8 Percentage vragen dat tijdens de voortgangstoets is beantwoord met juistlonjuist met een bepaalde mate van zekerheid, uitgesplitst naar kennisniveau

\begin{tabular}{|c|c|c|c|c|}
\hline & $\begin{array}{l}\text { minste } \\
\text { kennis }\end{array}$ & $\begin{array}{l}\text { gem. } \\
\text { kennis }\end{array}$ & $\begin{array}{l}\text { meeste } \\
\text { kennis }\end{array}$ & F-waarde \\
\hline $0 \%$ zeker & 2.90 & 4.42 & 9.43 & $3.976 *$ \\
\hline $25 \%$ zeker & 16.75 & 18.19 & 27.41 & $4.504 * a$ \\
\hline $50 \%$ zeker & 42.22 & 49.81 & 60.29 & $8.680^{* \ldots 10}$ \\
\hline $75 \%$ zeker & 78.31 & 80.05 & 88.74 & $6.203^{* \circ 5}$ \\
\hline zeker & 93.87 & 97.31 & 97.33 & $4.063 * b$ \\
\hline alle vragen & 29.91 & 33.46 & 46.01 & $19.450 * * *$ \\
\hline
\end{tabular}

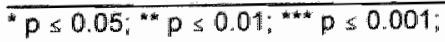

"minste kennis, *meeste kennis;" "minste kennis, gem. kennis *meeste keninis

Als indicatie van het kennisniveau is de indeling van studenten in drie groepen op basis van de goed-min-fout score gehanteerd (zie analyse paragraaf). Uit de tabel blijken verschillen tussen de drie kennisniveau-groepen in het aandeel vragen dat wordt beantwoord voor de toets in zijn geheel, maar ook voor de vragen die met een verschillende mate van zekerheid zijn beantwoord. De groep studenten met het laagste kennisniveau beantwoordt het minste vragen (29.9\% van alle vragen wordt beantwoord) en beantwoordt tevens bij elke mate van zekerheid eveneens het kleinste aandeel (bijv. $2.9 \%$ van de "O \% zeker-antwoorden" zijn beantwoord tijdens de voortgangtoets). Studenten met de meeste kennis beantwoorden bij de verschillende mates van zekerheid het grootste aandeel van de vragen. De verschillen zijn voor elke mate van zekerheid en voor het totaal van alle vragen significant.

Verschillen in het aantal vragen dat uiteindelijk correct is beantwoord tussen de drie kennisniveau groepen, tijdens de voortgangstoets en tijdens de experimentele voortgangstoets zijn weergegeven in de tabellen 2.9 en 2.10 . Opnieuw wordt om de percentages op hun waarde te kunnen schatten tussen haakjes vermeld welke fractie deze vragen met onjuist/juist (in tabel 2.9j of vraagteken (in tabel 2.10 ) uitmaken van de totale 233 vragen. De percentages uit de twee tabellen opgeteld vormen $100 \%$. 
Tabel 2.9 Percentages correcte antwoorden op vragen die tijdens de voortgangstoets zijn beantwoord, uitgesplitst naar kennisniveau (fractie van alle 233 vragen)

\begin{tabular}{|c|c|c|c|c|c|c|c|c|}
\hline \multirow[b]{2}{*}{$0 \%$ zeker } & \multicolumn{2}{|c|}{ minste kennis } & \multicolumn{2}{|c|}{ gem. kennis } & \multicolumn{2}{|c|}{ meeste kennis } & \multirow{2}{*}{$\begin{array}{l}\text { significantie } \\
\% \text { correct } \\
0.099 \mathrm{~ns}\end{array}$} & \multirow{2}{*}{$\begin{array}{l}\text { significantie fractie } \\
\text { van de vragen }\end{array}$} \\
\hline & 60.22 & (1.3) & 61.34 & $(1.8)$ & 57.95 & $(2.3)$ & & \\
\hline $25 \%$ zeker & 51.45 & (2.9) & 64.68 & (3.1) & 62.29 & (5.9) & $4.184 * 8$ & $7.283^{* 1 *}$ \\
\hline $50 \%$ zeker & 60.99 & $(6.8)$ & 64.55 & $(7.7)$ & 65.08 & $(11.1)$ & $1.455 \mathrm{~ns}$ & $10.710^{*}=1.6$ \\
\hline $75 \%$ zeker & 65.60 & $(11.0)$ & 71.57 & $(11.6)$ & 74.46 & $(15.4)$ & $9.049^{* * * b}$ & $10.284 \cdots$ \\
\hline zeker & 84.54 & (7.9) & 87.23 & $(9.3)$ & 89.07 & $(11.3)$ & $3.192 * \cdots$ & $5.525 * \approx$ \\
\hline GminF & 7.46 & $(29.9)$ & 10.75 & $(33.5)$ & 16.53 & $(46.0)$ & $111.646^{* * *}$ & $19.450 * * *$ \\
\hline
\end{tabular}

*p $\leq 0.05 ; * * 0 \leq 0.01 ; " * * * 0.001$;

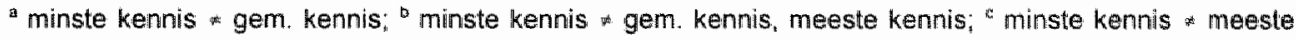
kennis; NB de goed-min-fout score tijdens de voortgangstcets gold als indelingsvariabele voor kennisniveau

De tabel laat zien dat de studenten met de meeste kennis een groter aandeel van de vragen (met een bepaalde zekerheid) beantwoorden en bovendien meestal het hoogste aandeel correct hebben. Op de vragen waarvan zij $25 \%$, $75 \%$ en $100 \%$ zeker zijn, is dit aandeel correcte antwoorden significant hoger dan één of beide andere groepen.

Tabel 2.10 Gemiddelde percentages correcte antwoorden op vragen die met vraagteken zijn beantwoord, uitgesplitst naar kennisniveau (fractie van alle 233 vragen)

\begin{tabular}{|c|c|c|c|c|c|c|c|c|}
\hline \multirow[b]{2}{*}{$0 \%$ zeker } & \multicolumn{2}{|c|}{ minste kennis } & \multicolumn{2}{|c|}{ gem. Kennis } & \multicolumn{2}{|c|}{ meeste kennis } & \multirow{2}{*}{$\frac{\begin{array}{c}\text { significantie } \\
\% \text { correct }\end{array}}{2.314 \mathrm{~ns}}$} & $\begin{array}{l}\text { significantie fractie } \\
\text { van de vragen }\end{array}$ \\
\hline & 51.03 & $(42.5)$ & 50.41 & $(40.3)$ & 52.57 & $(31.2)$ & & 11629 \\
\hline $25 \%$ zeker & 54.94 & $(15,4)$ & 54.28 & $(15.1)$ & 57.48 & $(13.7)$ & $1.256 \mathrm{~ns}$ & $1.124 \mathrm{~ns}$ \\
\hline $50 \%$ zeker & 56.10 & $(9.1)$ & 57.49 & (8.1) & 54.97 & $(6.9)$ & $0.409 \mathrm{~ns}$ & $2,859 \mathrm{~ns}^{\mathrm{b}}$ \\
\hline $75 \%$ zeker & 60.48 & $(2,7)$ & 56.59 & $(2.7)$ & 65.51 & $(1.8)$ & $1.365 \mathrm{~ns}$ & $2.421 \mathrm{~ns}$ \\
\hline zeker & 6061 & $(0.5)$ & 66.10 & $(0.3)$ & 66.54 & $(0.4)$ & $0.161 \mathrm{~ns}$ & $0.473 \mathrm{~ns}$ \\
\hline Gminf exp. & 6.40 & $(70.1)$ & 5.45 & $(66.5)$ & 8.45 & $(54.0)$ & $1.952 \mathrm{~ns}$ & $19.450 *$ * \\
\hline
\end{tabular}

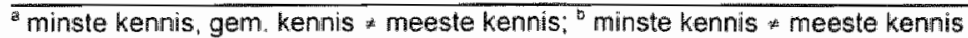

Ook voor de vragen die met het vraagteken zijn beantwoord geldt dat studenten met de meeste kennis meestal het hoogste aandeel correcte antwoorden hebben bij de verschillende mate van zekerheid. De vragen die met '50\% zeker' zijn beantwoord vormen hier een uitzondering op. Bij de antwoorden 
op de vragen die met vraagteken zijn beantwoord is het hogere aandeel correcte antwoorden echter niet significant.

De gemiddelde groep verschilt nauwelijks van de groep met de minste kennis, noch in de hoeveelheid vragen die met vraagteken zijn beantwoord, noch in het aandeel van de vragen dat correct is beantwoord.

De studenten met het hoogste kennisniveau behalen niet alleen de hoogste score tijdens de reguliere toets, maar ook tijdens de experimentele toets de hoogste score op vragen die tijdens de toets met vraagteken zijn beantwoord.

\section{Verschil in beleving omtrent mate van gokken en het kennisniveau}

Studenten met een vergelijkbare hoeveelheid kennis, kunnen een verschillende beleving hebben van wat zij beschouwen als ' $0 \%$ zeker', ' $25 \%$ zeker", etc. Dit doorredenerend betekent dat er ondanks een vergelijkbare indicatie wan beleving van 'zekerheid' toch verschillen optreden in het percentage vragen dat met een bepaalde mate van zekerheid correct wordt beantwoord. In tabel 2.11 worden verschillen weergegeven in het percentage correcte antwoorden tussen studenten met een variërend kennisniveau.

Tabell 2.11 Percentage correct van vragen beantwoord tijdens voortgangstoets of experimentele toets met bepaalde mate van zekerheid, uitgesplitst naar verschillend kennisniveau

\begin{tabular}{|c|c|c|c|c|c|c|c|c|}
\hline & \multicolumn{2}{|c|}{ minste kennis } & \multicolumn{2}{|c|}{ gem. kennis } & \multicolumn{2}{|c|}{ meesle kennis } & \multicolumn{2}{|c|}{ significantie } \\
\hline & VGT & $\exp$ & VGT & $\exp$ & VGT & $\exp$ & VGT & $\exp$ \\
\hline $0 \%$ zeker & 60.22 & 51.03 & 61.34 & 50.41 & 57.95 & 52.57 & $0.099 \mathrm{~ns}$ & $2.314 \mathrm{~ns}$ \\
\hline $25 \%$ zeker & 51.45 & 54.94 & 64.68 & 54.28 & 62.29 & 57.48 & $4.184 * \approx$ & $1.256 \mathrm{~ns}$ \\
\hline $50 \%$ zeker & 60.99 & 56.10 & 64.55 & 57.49 & 65.08 & 54.97 & $1.455 \mathrm{~ns}$ & $0.409 \mathrm{~ns}$ \\
\hline $75 \%$ zeker & 65.60 & 60.48 & 71.57 & 56.59 & 74.46 & 65.51 & $9.049 * * * b$ & $1.365 \mathrm{~ns}$ \\
\hline zeker & 84.54 & 60.61 & 87.23 & 66.10 & 89.07 & 66.54 & $3.192 * c$ & $0.161 \mathrm{~ns}$ \\
\hline
\end{tabular}

"minste kennis $*$ gem. kennis; ${ }^{b}$ minste kennis * gem. kennis, meeste kennis; "minste kennis * meeste kennis

Uit de tabel blijkt dat bij een zelfde markering van zekerheid niet hetzelfde percentage aan correcte antwoorden wordt verkregen. Enerzijds blijkt een discrepantie in percentages correct tussen vragen die met juist/onjuist zijn beantwoord en vragen die met vraagteken zijn beantwoord. Anderzijds blijkt er tussen studenten, in dit geval tussen studenten met verschillend kennis- 
niveau, een verschil in correcte antwoorden bij het beantwoorden met lagere zekerheid.

Het hoogste aandeel correct wordt tijdens de voortgangstoets behaald door de middengroep op de vragen met lage zekerheidsaanduiding ( $0-25 \%$ zeker) en door de studenten met de meeste kennis op de vragen met de hogere zekerheidsaanduidingen (50 - $100 \%$ zeker). De verschillen zijn hierbij in een aantal gevallen significant.

Bij de vragen die met vraagteken zijn beantwoord zijn de verschillen minder duidelijk (en niet significant). Ook bij deze vragen is er een trend naar het hoogste rendement ten gunste van de studenten met de meeste kennis. Dit betekent dat studenten met de meeste kennis bovendien de meeste kennis onbenut laten door vragen te beantwoorden met vraagteken.

\section{Discussie en conclusie}

In de beschreven studie is nagegaan hoe (on)zeker studenten zijn over vragen die zij met juist of onjuist beantwoorden, ofwel vragen waarbij zij gebruik maakten van de vraagtekenoptie. Vervolgens is nagegaan of eventuele verschillen in antwoordbereidheid gerelateerd zijn aan toetsresultaten.

Gebruik uraagtekenoptie en mate van zekerheid van de antwoorden. Bij de voortgangstoets van Gezondheidswetenschappen wordt op betrekkelijk grote schaal gebruik gemaakt van het vraagteken. Gemiddeld wordt ruim $60 \%$ van de vragen beantwoord met een vraagteken. De $40 \%$ beantwoorde vragen beantwoorden studenten voor ongeveer een kwart met een vrij grote zekerheid (75 - $100 \%$ zeker). Wanneer onderscheid wordt gemaakt tussen puur gokken en geïnformeerd gokken (Ebel, 1970) waarbij de zekerheidsaanduiding '0 \% zeker' als 'puur gokken' en '25 - $75 \%$ zeker' als 'geïnformeerd gokken' wordt beschouwd, blijkt in geval van de voortgangstoets slechts op een klein gedeelte van de vragen (nog geen twee procent) puur te worclen gegokt. Evenals in de onderzoeken van Cross en Frary (1977), Rowly en Traub (1977) en Sherriffs en Boomer (1954) blijken studenten op de items die zij puur gokken hoger te scoren dan op basis van kansberekening verwacht wordt. De hoeveelheid correct beantwoorde vragen boven kans niveau op eerder genegeerde items voor 'puur gokken' antwoorden is echter beperkt (51.4\% correct ten opzichte van $50 \%$ volgens kansberekening). Ook bij 
grotere mate van zekerheid beantwoorden studenten (op groepsniveau) meer vragen goed dan fout, waarbij met het toenemen van de mate van zekerheid ook het aandeel correcte vragen oploopt.

Ook voor de vragen die zijn beantwoord met een vraagteken geldt op groepsniveau dat bij elke mate van zekerheid het aantal correcte antwoorden groter is dan het aantal incorrecte antwoorden. Wel blijkt bij de antwoorden met vergelijkbare mate van (on-) zekerheid het aandeel correcte antwoorden op de juist/onjuist antwoorden hoger te zijn is dan op de vraagteken antwoorden. Studenten blijken de inschatting van zekerheid dus niet geheel zuiver te kunnen maken, of bij het beantwoorden van vragen spelen ook andere factoren dan de inschatting van de eigen kennis een rol.

De bewering van een hoger aantal correct boven kansberekeningsniveau voor items waarop 'puur wordt gegokt' van Cross en Frary (1977), Rowly en Traub (1977) en Sherriffs en Boomer (1954) blijkt niet generaliseerbaar naar items waarop 'geinformeerd wordt gegokt'. Het verwachte percentage correct met verrekening van kennis $(52.5 \%$ voor $25 \%$ zeker tot $100 \%$ voor zeker) ligt hoger dan het feitelijke percentage correct. Objectief gezien betekent dit op groepsniveau dat alle vragen beantwoorden leidt tot hogere scores. Hierbij dient niet uit het oog verloren te worden dat de toets gebruikt wordt om beslissingen te nemen op individueel niveau. Op individueel niveau blijkt het beantwoorden van alle vragen voor slechts een kleine twintig procent van de studenten te resulteren in een lagere toetsscore en dus voor de overige studenten tot een hogere score (Van Til \&o Van. Berkel, 1995).

Risico nemen en resultaat op de voortgangstoets. De suggestie van Cross en Frary (1977) dat studenten die minder risico nemen succesvoller zijn op items die ze 'blind gokken' dan studenten die meer risico nemen blijkt onder de toetscondities van de huidige voortgangstoets niet op te gaan. Wanneer verondersteld wordt dat studenten die risico-voller antwoorden de vragen gemiddeld met een lagere zekerheidsaanduiding beantwoorden blijken studenten die het meeste risico nemen de meeste vragen te beantwoorden. Bovendien hebben zij bij elke mate van zekerheid het hoogste percentage correct. Dus zelfs van de vragen die door deze groep met lagere zekerheid worden beantwoord is het gedeelte correcte vragen groter dan voor de studenten die minder risico nemen. Deze bevinding kan niet worden verklaard met de suggestie dat studenten die meer risico nemen minder kennis laten liggen en minder goed scoren op de genegeerde items. Tussen de groepen 
studenten blijken nauwelijks verschillen op de 'vraagteken-antwoorden' in de percentages correct. Marginale verschillen wijzen eerder in de richting van het laagste percentage correct voor de groep studenten die een gemiddeld risico nemen.

Wel lijkt het erop dat studenten die minder risico nemen met het beantwoorden van minder vragen waarover zij zekerder zijn ongeveer evenveel punten halen als studenten die meer risico nemen. Dat de studenten die het meeste risico nemen toch de hoogste score behalen wordt waarschijnlijk grotendeels veroorzaakt door het grotere aantal vragen dat zij beantwoorden. Immers, het beantwoorden van vragen, met elke mate van zelkerheid, levert fop groepsniveau) per saldo een verhoging van de goed-min-fout score op. In elk geval kan geconcludeerd worden dat er momenteel, met name op basis van het aantal goede antwoorden op vragen welke tijdens de reguliere toets met vraagteken werden beantwoord, geen sprake is van selectief bevoordelen van studenten die meer risico durven nemen.

Kennisniveau en aandeel correcte antwoorden op eerder genegeerde vragen. De veronderstelling van Grosse en Wright (1985) dat studenten met de minste kennis het meeste gokken blijkt slechts gedeeltelijk op te gaan. Inderdaad blijkt een samenhang tussen kennisniveau en neiging tot antwoorden. Studenten met meer kennis beantwoorden significant meer vragen, zowell meer vragen met een lage mate van zekerheid als meer vragen met een hoge mate van zekerheid. Hetgeen met meer kennis niet verwonderlijk is.

Bij de groep studenten met meer kennis is het rendement (percentage goed) van de antwoorden bij lage zekerheden iets lager in vergelijking tot de andere groepen en bij hogere zekerheden (50\% en meer) is het aandeel correcte antwoorden significant hoger. Per saldo levert dit de studenten met de meeste kennis ook bij lage zekerheden nog steeds een positieve goed-min-fout score op warbij dit slechts een klein gedeelte van de vragen betreft. De groep studenten met de minste kennis beantwoordt de minste vragen en heeft bovendien het laagste rendement.

Ook voor kennisniveau blijkt de verklaring niet gevonden te kunnen worden in het feit dat studenten met minder kennis neigen naar meer antwoorden. (en dus (geinformeerd) gokken). Studenten met een hoger kennisniveau hebben namelijk ook een hoger aandeel correcte antwoorden op de met vraagteken beantwoorde items. In dit geval zijn de verschillen weliswat minder groot en niet altijd significant. Echter, deze groep studenten behaalt 
wel een significant hogere goed-min-fout score op de items die in eerste instantie met vraagteken zijn beantwoord.

De resultaten suggereren onder de huidige scoringswijze van de voortgangstoets dus eerder het tegengestelde van de veronderstelling van Grosse en Wright (1985). Studenten met een hoger kennisniveau bij goed-min-fout scoring met vraagteken-optie worden eerder benadeeld dan de studenten met minder kennis, doordat deze studenten meer kennis 'laten liggen'. De suggestie van Grosse en Wright dat de validiteit het laagst is daar waar deze het meest is gewenst lijkt hiermee niet gegrond. Niet de groep studenten waarbij een beslissing 'onvoldoende' of 'onvoldoende-twijfel' moet worden genomen, maar de studenten die zeker zijn van minimaal een voldoende worden benadeeld.

Beleving omtrent mate van gokken en het kennisniveau. Gross (1982) bekritiseert de toepassing van correctie voor gokken vanwege een verschillende beleving van studenten voor welk antwoord geldt als een gok en welk antwoord geldt als weten. Dit verschijnsel blijkt inderdaad op te treden bij de voortgangstoets. Allereerst blijkt dat de rendementspercentages op vragen die met juist/onjuist zijn beantwoord tijdens de toets hoger liggen dan op de vragen die met vraagteken zijn beantwoord, ondanks vergelijkbare mate van zekerheidsaanduiding. Kennelijk zijn er ook andere factoren die een rol spelen bij het al of niet beantwoorden van een vraag met vraagteken, zoals bijvoorbeeld formulering van vragen.

Bovendien zijn er groepswerschillen bij vergelijking van percentages correcte antwoorden op vragen die met gelijke mate van zekerheid zijn beantwoord. Studenten met het hoogste kennisniveau hebben het hoogste aandeel correcte antwoorden bij de meeste maten van zekerheid, op juist/onjuist antwoorden veelal significant. Maar ook op vraagteken-antwoorden suggereren de bevindingen het gunstigste rendement bij deze groep, zij het minder duidelijk en niet significant. Deze bevindingen indiceren dus eerder een 'bescheidener' inschatting van kennis van de studenten met het hoogste kennisniveau. Waarschijnlijk zijn er dus inderdaad verschillen tussen studenten in de beleving wat geldt als een gok en wat geldt als weten.

De bevinding dat studenten meer vragen goed dan fout beantwoorden op vragen die in eerste instantie met een vraagteken zijn beantwoord introduceert verschillen tussen studenten. Deze verschillen blijken niet duidelijk 
groepsgerelateerd aan de mate waarin studenten tijdens de voortgangstoets risico's nemen of aan de studenten met de minste kennis, gemiddelde of de meeste kennis. De verschillen zijn echter in dusdanige richting dat de studenten met de volgens de huidige scoringsregel meeste kennis, door de scoringsregel het meest benadeeld worden. Bovendien treden er tussen studenten verschillen op in wat zij in hun beleving ervaren als gokken en als weten en ook hier indiceren de conclusies eerder een benadeling van de studenten met de meeste kennis dan de studenten met de minste kennis.

Funest is dat de feitelijke antwoordinstructie 'Het vraagteken vul je in als je de vraag hebt gelezen en hebt nagedacht over het mogelijke antwoord maar het goede antwoord niet weet' niet expliciet benadrukt dat bij enig idee over de vraag studenten deze het best kunnen beantwoorden. In hoeverre het nadeel van te weinig vragen beantwoorden door onderschatten van kennis of voorzichtigheidsoverwegingen telkens dezelfde studenten treft kan op basis van deze eenmalig verrichte studie niet worden geconcludeerd.

Wanneer vanuit veronderstelde implicaties voor het onderwijs toch wordt vastgehouden aan het belang van de vraagtekenoptie zal nagedacht moeten worden over een andere scoringsregel. Dirkzwager (1996) oppert het hanteren van kansschattingen met een door de student daaraan gekoppelde variabele toekenning van (belonende of bestraffende) puntentelling als oplossing voor het benadelen van studenten onder goed-min-fout scoring als oplossing. De studie in dit hoofdstuk heeft echter ook zichtbaar gemaakt hoe moeilijk het is voor studenten een reële inschatting te geven van hun kennisniveau, wat hoogstwaarschijnlijk opnieuw zal leiden tot niet aan kennis gerelateerde bias. Bovendien zijn dergelijke scoringsmethoden weinig inzichtelijk voor studenten ten aanzien van de meest optimale antwoordstrategie. Aangezien ook de instructie, met de benoemde gokcorrectie, variatie tussen studenten in antwoordgedrag met zich meebrengt (Slakter, 1968) is het de vraag welke bias met dit gebrek aan inzichtelijkheid wordt geïntroduceerd. Op basis van dit onderzoek kan geconcludeerd worden dat tenminste de huidige antwoordinstructie aangescherpt moet worden en bovendien moet worden heroverwogen met welke aanpassing in de gehanteerde scoringsregel gokken op een acceptabele manier kan worden ontmoedigd. 



\section{Probleemgestuurd studiegedrag: een studie naar studiegedrag in relatie tot toetsvoorbereiding en toetsscores ${ }^{4}$}

In dit derde hoofdstuk wordt een studie beschreven waarin studenten zijn onderscheiden op basis van hun studiegedrag en studie-activiteiten in typen probleemgestuurd studiegedrag. Nagegaan is of studenten met verschillend probleemgestuurd studiegedrag op dezelfde wijze (niet) specifiek studeren voor de voortgangstoets. Tevens is nagegaan of studiegedrag dat sterker overeenkomt met de gedachte achter probleemgestuurd onderwijs leidt tot betere voortgangstoetsresultaten. De resultaten van de hier beschreven studie zijn gebaseerd op een vragenlijstonderzoek. Deze uragenlijst, welke specifiek is ontwikkeld voor dit onderzoek en is afgestemd op probleemgestuurd onderwijs, is in de eerste blokperiode van studiejaar 1995-1996 beantwoord door 164 studenten uit het tweede tot en met vierde studiejaar Gezondheidswetenschappen.

\section{Inleiding en probleemstelling}

Probleemgestuurd onderwijs beoogt studenten aan te sturen tot studieactiviteiten. Deze activiteiten moeten leiden tot kennis die beter wordt onthouden en toegankelijker is. De kennis wordt bij voorkeur op actieve wijze, vanuit de eigen vraagstelling van studenten verworven en aangeleerd binnen een relevante context. (Norman \& Schmidt, 1992; Schmidt, 1983). Met het doorlopen van de verschillende fasen van het probleemgestuurd onderwijs wordt verondersteld aan te sturen tot cognitieve processen die het verkrijgen van kennis en leren stimuleren (Schmidt, 1983). Met het definiëren en analyseren van problemen activeren studenten hun voorkennis. Dit stuurt

\footnotetext{
4 Een gedeelte van dit onderzokk is gepresenteerd tijdens de American Educational Association (AERA) meeting te Chicago, Maart, 1997. Education Resources Information Center (ERIC) Document Reproduction Service No. TM 026783, (Wan Til, Van der Vletten Ran Berkel, 1997 a) en het Gezond Onderwijs Congres (GOC-5) te Veldhoven, 1995 (Van Til, Van Berkel \& Van der Vleuten, 1996
} 
Hoojdstuk 3

het leren en faciliteert het begrijpen van nieuwe kennis. Het aan elkaar uitleggen en organiseren van mogelijke verklaringen maakt dat geleerde kennis in een groter geheel wordt geplaatst. Bovendien draagt de groepsdiscussie in de voor- en nabespreking ertoe bij dat studenten op een actieve wijze hun kennis verwerven en toetsen (Norman \& Schmidt, 1992). De afzonderlijke onderdelen van het leerproces, de stappen van de zevensprong, vormen binnen probleemgestuurd onderwijs een aanvulling op elkaar, waarbij zowel het gedrag in de onderwijsgroep tijdens de voor-en nabespreking als de zelfstudie bijdragen aan leren en kennisopbouw (De Grave, Boshuizen \&o Schmidt, 1996) (zie ook hoofstuk 1).

De voortgangstoets is in principe zodanig ontworpen dat deze aansluit op de leeractiviteiten die van studenten in probleemgestuurd onderwijs worden verlangd. De toets richt zich niet op het directe leereffect van het blokgebonden onderwijs, maar op de kennis die ook na afloop van de blokperioden is blijven hangen (Van der Vleuten, Verwijnen \& Wijnen, 1996). Bovendien moet het ontbreken van de directe koppeling tussen het gevolgde onderwijs en de toetsafname ervoor zorgen dat studenten zich niet gaan voorb sreiden op de toets ten koste van de activiteiten voor de onderwijsgroep (Van der Vleuten, Verwijnen \& Wijnen, 1996).

Het feit dat het onderwijs is vormgegeven volgens de principes van probleemgestuurd leren betekent niet dat alle studenten ook handelen volgens deze principes. In de praktijk blijken er grote verschillen tussen studenten in zowel wat zij doen aan activiteiten in de onderwijsgroep en tijdens de zelfstudie, als aan de wijze waarop zij gebruik maken van probleemgestuurd onderwijs (Van Til, Pronk \& Van der Heijden, 1997).

Indien de voortgangstoets aansluit op de leeractiviteiten die van studenten worden verlangd zullen studenten deze leeractiviteiten ook beloond moeten zien in hun resultaten op de toets. Individuele zelfstudie-activiteiten en activiteiten in de onderwijsgroep worden teruggezien in groei op de voortgangstoets (Van der Vleuten, Verwijnen \& Wijnen, 1996). De toets veronderstelt zich niet te richten op directe leereffecten, leereffecten wan korte termijn toetsgericht studeren, maar op kennis die ook na afloop van de blokperioden blijft hangen. In het verrichte onderzoek wordt nagegaan of wenselijk probleemgestuurd studiegedrag leidt tot betere resultaten op de voortgangstoets. 
De centrale probleemstelling luidt: "zijn er verschillen tussen studenten in probleemgestuurd studiegedrag en hun voorbereiding op de voortgangstoets en de resultaten die zij op de voortgangstoets behalen?"

\section{Achtergrond probleemgestuurd studiegedrag}

Onderzoek naar de studie-activiteiten van studenten richt zich veelal op de activiteiten tijdens de zelfstudie. In onderzoek naar zelfstudie wordt over het algemeen aangenomen dat studenten een verschillende studiestijl of studiestrategie hanteren (onder andere Biggs, 1979; Entwistle 8 Ramsden, 1983; Marton \& Säljö, 1984). Een bekende indeling is het onderscheid in diep en oppervlakkig leren (Marton \& Säljö, 1984). Biggs (1979) en Entwistle en Ramsden (1983) hebben onafhankelijk van elkaar een derde zelfstudiestijl onderscheiden, namelijk een strategische aanpak van de studie. Binnen deze studiestrategie hanteren studenten afwisselend een diepte of oppervlakte benadering, afhankelijk van datgene wat in de onderwijsomgeving van hen gevraagd wordt. De studiestrategie wordt aangepast op basis van de verwachtingen van studenten over de gunstigste resultaten.

In tabel 3.1 zijn de kenmerken van de intellectuele processen die studenten gebruiken om de leerstof te bestuderen bij de verschillende leerstijlen, gebaseerd op onderzoek van Pask (1976), samengevat (Entwistle, 1988). De gehanteerde leerprocessen bepalen de kwaliteit van het leerresultaat (Newble 8. Entwistle, 1986).

Tabel 3.1 Kenmerken van gebruikte leerprocessen bij de verschillende leerstijlen

\begin{tabular}{|c|c|c|c|c|}
\hline \multirow{2}{*}{$\begin{array}{c}\text { Oppervlakkig } \\
\text { Memoniseren }\end{array}$} & \multicolumn{3}{|c|}{ Diep } & \multirow{2}{*}{$\frac{\text { Strategisch }}{\text { Afwisselend }}$} \\
\hline & Analyseren & Relateren & Begripen & \\
\hline $\begin{array}{l}\text { - Gericht op taken } \\
\text { en geilsoleerde } \\
\text { onderdelen } \\
\text { - Toepassing van } \\
\text { standiaard } \\
\text { procedures en } \\
\text { regels om feiten } \\
\text { en ideeern uit het } \\
\text { noofd te leren }\end{array}$ & $\begin{array}{l}\text { - Stap voar stap } \\
\text { analyseren van } \\
\text { studiemateriaal } \\
\text { - Zorgvuldig bij het - } \\
\text { toepassen van } \\
\text { generalisaties } \\
\text { - Aandacht voor } \\
\text { feiten en } \\
\text { procedurele } \\
\text { details }^{\text {a }}\end{array}$ & $\begin{array}{l}\text { - Aandacht voor } \\
\text { zowel analyseren } \\
\text { als begrijpen } \\
\text { - Goede match } \\
\text { tussen } \\
\text { gedetailleerd } \\
\text { bewijismateriaal en } \\
\text { globale lijn om } \\
\text { volledig begrip van } \\
\text { de stof te krijgen }\end{array}$ & $\begin{array}{l}\text { - Opzoek naar } \\
\text { globale lijnen } \\
\text { - Verbanden leggen } \\
\text { tussen concepten } \\
\text { en woorkenmis } \\
\text { - Gebruikmaken van } \\
\text { anallogieen } \\
\text { - Zoeken naar het } \\
\text { verkrijgen van } \\
\text { begrip van de stof }\end{array}$ & $\begin{array}{l}\text { Afwisselend } \\
\text { een diepe of } \\
\text { oppervlakkige } \\
\text { leerstrategie } \\
\text { gebruiken, } \\
\text { afhankelijk van } \\
\text { de perceptie } \\
\text { welke het beste } \\
\text { resultaat aple } \\
\text { wert }\end{array}$ \\
\hline
\end{tabular}

${ }^{a}$ Risico voor leerpathologie te delaillistisch studeren; ${ }^{b}$ Risico voor leerpathologie te globaal studeren 
Vermunt (1992) beschrijft dat de meeste leerstijlen in een smalle en brede betekenis worden gebruikt. In de smalle betekenis worden leerstijlen met name beschreven in termen van cognitieve verwerkingsactiviteiten. In zijn opinie bevatten leerstijlen "een breed concept waarin samenhangen tussen cognitieve en affectieve verwerking van leerstof, de meta-cognitieve regulatie van leerprocessen, mentale leermodellen en leeroriëntaties worden verenigd" (pagina 20-21). Leerstijlen kunnen dus onder andere betrekking hebben op verwerkingsactiviteiten en regulatie-activiteiten. De verwerkingsactiviteiten van studenten kunnen zowel door henzelf als door de omgeving worden beinvloed en aangestuurd. In figuur 3.1 wordt een overzicht gegeven van de verwerkings- en regulatie-activiteiten die door Vermunt zijn onderscheiden.

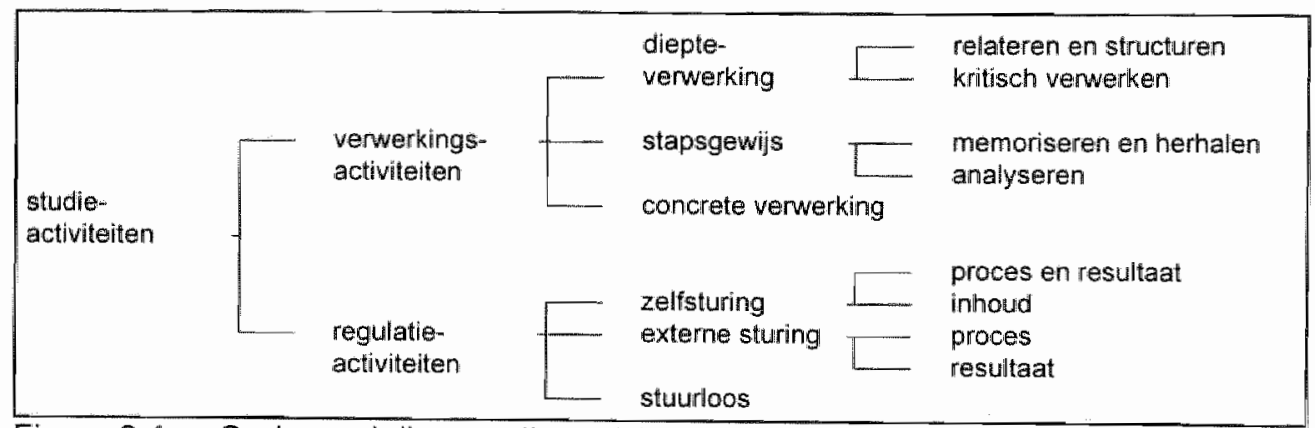

Figuur 3.1 Onderverdeling studie-activiteiten in verwerkings- en regulatie activiteiten, met de gehanteerde (sub-) schalen

Het toepassen van een strategische leerstrategie zoals beschreven door Biggs (1976) en Entwistle en Ramsden (1983) kan hoogstwaarschijnlijk verklaard worden door regulatie activiteiten zoals deze door Vermunt (1992) zijn beschreven.

Denkactiviteiten die behoren tot een diepte-aanpak, zoals relateren, structureren en concretiseren, leiden tot kwalitatief betere leerresultaten dan de memoriserende activiteiten (Hilliard, 1995; Van Rossum \& Schenk, 1984). Vermunt (1992) concludeerde dat betekenisgerichte en toepassingsgerichte leerstijlen positief samenhangen met tentamenresultaten en een ongerichte leerstijl negatief. Deze, zij het bescheiden, positieve correlatie is met name toe te schrijven aan relaterende en structurerende verwerkingsstrategieën. Een kritische verwerkingsstrategie draagt in mindere mate bij, terwijl de analytische, concrete en memoriserende verwerkingsstrategieën nauwelijks bijdragen tot betere tentamenresultaten. In andere studie wordt geen 
verschil gevonden op kwantitatieve gegevens in de vorm van toetsresultaten. maar wel op kwalitatieve gegevens (Trigwell \&. Prosser, 1991). Studenten die hoger scoren op subschalen van diepteverwerking en relateren zijn beter in staat kenmerken van de cursus in de vorm van de rode draad, het overzicht, verbanden met andere cursussen, etc. te benoemen. Voor het onderwijs is het echter vooral van belang dat studenten de studie-activiteiten verrichten die worden beoogd met het onderwijs (Norman, 1992; Vermunt, 1996).

De bovengenoemde studies vonden allen plaats binnen een conventionele onderwijssetting. Bij probleemgestuurd onderwijs wordt ernaar gestreefd studenten met het toepassen van de zevensprong (of varianten hiervan), te stimuleren tot diepe leeractiviteiten. Verondersteld wordt dat deze leeractiviteiten beter aansluiten bij onderwijsdoelstellingen als: zelfgestuurd leren, kritisch denken, probleemoplossend vermogen, etc. (Blake, Norman, Kinsey \& Smith, 1995; Norman \& Schmidt, 1992; Norman \& Regehr, 1994). In studies van Coles (1985) en Newble en Clarke (1986) zijn aanwijzingen gewonden dat studenten uit een probleemgestuurd curriculum tijdens de zelfstudie hoger op een diepte-verwerkingsschaal en lager op een oppervlakkigeverwerkingsschaal scoren dan studenten uit een traditioneel curriculum.

In een onderzoek binnen een probleemgestuurde onderwijssetting suggereerden de resultaten betere prestaties voor studenten die tijdens de zelfstudie een begrijpende leerstijl hanteren ten opzichte van studenten die een memoriserende leerstijl hanteren (Van Berkel, Nuy \& Geerligs, 1995).

Al deze studies zijn echter alleen gericht op de studie-activiteiten tijdens de zelfstudie terwijl bij probleemgestuurd onderwijs wordt verondersteld dat ook de activiteiten tijdens de andere stappen van de zevensprong bijdragen aan kennisverwerving. In een studie van Moust, Schmidt, De Volder, Beliën en De Grave (1986) is het effect van studie-activiteiten tijdens de brainstorm op leerprestaties onderzocht. In dit onderzoek werden studie-activiteiten geoperationaliseerd als het aantal verbale deelnamen aan de brainstorm. Studenten die tijdens de probleemanalyse weinig of geen verbale ideeën hardop benoemden wisten zich achteraf niet meer (of minder) feiten te herinneren dan studenten die dit wel deden. Een later onderzoek wan De Grave et al. (1996) laat echter zien dat actieve participatie in de onderwijsgroep slechts ten dele zichtbaar is. In dit onderzoek werden studenten individueel gevraagd met behulp van gemaakte video-opnames van een brainstorm in de onderwijsgroep, achteraf te reproduceren welke denkactiviteiten zij toen 
hadden. De bevindingen maken zichtbaar dat slechts een klein gedeelte van verwerkingsactiviteiten als elaboreren, hypothesen genereren, relateren, vragen stellen, etc. worden omgezet in zichtbare activiteiten.

Swanson et al. (1991) beargumenteren dat het te verwachten is dat verschillen in vaardigheden van studenten om het eigen leerproces te sturen en de motivatie voor de studie, in combinatie met conceptuele vermogens van studenten, resulteren in verschillende leereffecten. Tot op heden is geen onderzoek verricht waarin de invloed van variatie in binnen probleemgestuurd onderwijs veronderstelde studie-activiteiten op studieresultaten, is onderzocht. Om de invloed van studie-activiteiten tijdens alle fasen van de zevensprong globaal in kaart te brengen is voor deze studie een instrument ontwikkeld. Omdat studie-activiteiten in een onderwijsgroep niet altijd zichtbaar zijn, en binnen probleemgestuurd onderwijs ook niet zichtbare denkactiviteiten invloed kunnen hebben, maken ook niet zichtbare studie-activiteiten zoals denkactiviteiten, onderdeel uit van de vragenlijst.

Bij het in kaart brengen van probleemgestuurd studiegedrag spelen enerzijds de kenmerken van leerprocessen van leerstijlen en leerstrategieën een rol, waarbij het onderscheid tussen oppervlakte- en diepteverwerking wordt gemaakt. Kenmerken van leerprocessen als relateren, structureren en analyseren vinden niet alleen plaats tijdens de zelfstudie, maar ook in de reactiepatronen in de onderwijsgroepsbijeenkomsten. Gedrag wordt dan ook veelal beschreven vanuit het standpunt dat het ontstaat in een wisselwerking tussen persoonskenmerken en situatiekenmerken (Endler, 1988; Endler \& Parker, 1992). Deze wisselwerking is ook terug te vinden in de operationalisering van regulatie-activiteiten door Vermunt (1992) wanneer gesproken wordt van beinvloeding van studie-activiteiten door de onderwijsomgeving (of het onderwijsmateriaal). Hierbij kunnen studenten in dezelfde onderwijsomgeving tot verschillende activiteiten en gedragingen komen ten gevolge van onder andere persoonskenmerken. Het doorlopen van de zevensprong veronderstelt aan te sturen tot actieve participatie in de onderwijsgroep in de vorm van brainstormen, vragen stellen, uitleggen, studeren met behulp van de leerdoelen, etc.

Behalve de vraag op welke manier studenten zich gedragen binnen probleemgestuurd onderwijs in de onderwijsgroepen en tijdens de zelfstudie (hoe), speelt ook een rol welke activiteiten studenten verrichten, overeenkomstig de doelen van probleemgestuurd onderwijs (wat). De 'hoe' component zal 
verder de aard van probleemgestuurd studiegedrag worden genoemd en ten aanzien van de 'wat' component zal van de activiteit van probleemgestuurd studiegedrag worden gesproken. De twee componenten van probleemgestuurd studiegedrag hebben theoretisch elk een wenselijke en een minder wenselijke dimensie, respectievelijk diep versus oppervlakkig en actief versus passief probleemgestuurd studiegedrag. Tussen beide dimensies is een te veronderstellen samenhang en een koppeling levert vier mogelijke combinaties van typen studenten (zie figuur 3.2\%.

\begin{tabular}{|l|l|c|c|}
\hline \multirow{2}{*}{ Probleemgestuurd studiegedrag } & \multicolumn{2}{c|}{ Component 'activiteit van probleemgestuurd studiegedrag' } \\
\cline { 2 - 4 } & \multicolumn{1}{|c|}{ dimensie passief } & dimensie actief \\
\hline $\begin{array}{l}\text { Component } \\
\text { "aard van probleemgestuurd } \\
\text { studiegedrag' }\end{array}$ & $\begin{array}{l}\text { dimensie op- } \\
\text { pervlakkig }\end{array}$ & appervakkige passieve & $\begin{array}{c}\text { oppenlakkige actieve } \\
\text { studemt }\end{array}$ \\
\cline { 2 - 4 } & dimensie diep & diepe passieve student & diepe actieve student \\
\hline
\end{tabular}

Figuur 3.2 Typen probleemgestuurd studiegedrag

De leeractiviteiten die van studenten bij probleemgestuurd onderwijs worden verlangd zouden moeten leiden tot betere kennisverwerking waardoor studenten komen tot een beter begrip van de leerstof en vorming van een kwalitatief rijker semantisch netwerk. De opzet van de voortgangstoets is in principe zodanig dat deze aansluit op de leeractiviteiten die van studenten worden verlangd. De kennis die wordt verkregen met de activiteiten in de onderwijsgroep en de zelfstudie is het soort kennis dat zich ontwikkelt over een langere periode en zou ook op langere termijn worden onthouden fonder andere Norman et al., 1989; Wagner \& Sternberg, 1985). De voortgangstoets heeft dan ook de intentie kennis te meten die ook na afloop van de blokperioden is blijven hangen, in combinatie met relevante kennis die studenten op andere manieren verwerven (bijvoorbeeld televisie of vaktijdschriften). Bovendien is het de bedoeling dat de toetsafname zich niet richt op het directe leereffect van het blokgebonden onderwijs (Van der Vleuten, Verwijnen \& Wijnen, 1996). De vragen dienen zodanig te zijn dat ze ontwikkelde samengestelde kennis meten in plaats van onsamenhangende losse kennis van feiten (Swanson et al., 1991).

In traditionele curricula bestaan de onderwijsactiviteiten niet zelden uit beperkte studie-activiteiten tijdens de onderwijsperiode, waardoor vervolgens bij het naderen van een toets in korte tijd een grote hoeveellheid kennis 
bestudeerd of geleerd moet worden (onder andere Van der Drift \& Vos, 1987). In principe is bij probleemgestuurd onderwijs de aaneengeschakelde voorbereiding van de onderwijsgroepsbijeenkomsten voldoende en daarmee de veronderstelde wijze van toetsvoorbereiding. Op deze wijze zouden studenten hun kennis automatisch zien groeien, waarbij het nauwelijks noodzakelijk is vlak voor een toets gericht te gaan studeren.

\section{Vraagstellingen en veronderstellingen}

De eerder genoemde probleemstelling "zijn er verschillen tussen studenten in probleemgestuurd studiegedrag in voorbereiding op de voortgangstoets en de resultaten die zij op de voortgangstoets behalen" valt uiteen in een viertal vraagstellingen. Waar mogelijk zullen verwachte resultaten worden geformuleerd of zal de context van de vraagstelling worden geschetst.

Binnen probleemgestuurd onderwijs is het de bedoeling dat de opzet van taken, onderwijsgroepsbijeenkomsten, blokken, etc. uitnodigen tot actieve deelname aan en voorbereiding van de onderwijsgroepen. Bij voorkeur passen studenten hierbij kenmerken van diepte verwerking toe. De eerste vraagstelling is bedoeld inzicht te krijgen in het probleemgestuurd studiegedrag van studenten.

1. Hoe is het probleemgestuurd studiegedrag van studenten Gezondheidswetenschappen?

Het in kaart brengen van studie-activiteiten van studenten dient zich te richten op alle activiteiten van studenten in het doorlopen van het gehele onderwijsleerproces: de zevensprong. Tot op heden ontbreekt een instrument waarmee studie-activiteiten tijdens alle fasen van de zevensprong in kaart worden gebracht. De componenten 'aard' en 'activiteit', de dimensies 'oppervlakkig versus diep' en 'passief versus actief' en de typen 'diep - actief, 'diep passief, 'oppervlakkig - actief' en 'oppervlakkig - passief', zoals weergegeven in figuur 3.2 vormen hier het uitgangspunt voor.

In principe vormt bij probleemgestuurd onderwijs de deelname aan en voorbereiding van de onderwijsgroepsbijeenkomsten de automatische voorbereiding op toetsen. Dit maakt dat in principe nauwelijks specifiek voor een toets gestudeerd hoeft te worden. Bekend is echter dat er binnen onderwijssituaties van toetsing een sterke sturing uitgaat op studie-activiteiten fonder andere Newble \& Jeager, 1983; Newble \& Entwistle, 1986; Frederiksen, 1984). In hoeverre variatie bij probleemgestuurd studiegedrag samen gaat 
met een vorm van voorbereiden op toetsen wordt nagegaan in de volgende vraagstelling.

2. Zijn er in de woorbereiding op de voortgangstoets verschillen tussen studenten met variatie in probleemgestuurd studiegedrag?

Naar verwachting zullen studenten met studiegedrag dat overeen komt met wat en hoe dit binnen probleemgestuurd onderwijs verondersteld wordt zich minder voorbereiden op de voortgangstoets.

Probleemgestuurd onderwijs sluit aan op cognitieve leerprocessen, waarmee verondersteld wordt dat nieuwe kennis beter wordt onthouden (zie hoofstuk 1). Studenten zouden groei in kennis terug zien in hun voortgangstoetsresultaten (Van der Vleuten, Verwijnen 8. Wijnen, 1996). In hoeverre dit het geval blijkt wordt onderzocht met de volgende vraagstelling.

3. Zijn er verschillen in resultaten op de voortgangstoets tussen studenten met verschillend probleemgestuurd studiegedrag?

Naar verwachting leidt binnen probleemgestuurd onderwijs verondersteld studiegedrag tot betere kenniswerwerking, welke zichtbaar wordt in hogere toetsresultaten.

Naast inzicht in overeenkomsten en verschillen van toetsvoorbereiding en toetsresultaten tussen studenten met hun probleemgestuurd studiegedrag, is de onderlinge samenhang tussen deze variabelen van belang. De afzonderlijke en gezamenlijke invloed van studietijd, toetswoorbereiding en probleemgestuurd studiegedrag staan centraal in de laatste vraagstelling.

4. Wat is de invloed van probleemgestuurd studiegedrag op voortgangstoetsresultaten wanneer wordt gecorrigeend voor toetsvoorbereiding op de voortgangstoets?

Gewenst (problleemgestuurd) studiegedrag zou beloond moeten worden bij kennistoetsing, in dit geval in de voortgangstoets. Niet gewenst specifiek studeren voor de voortgangstoets zou in dit geval niet beloond mogen worden.

\section{Methode}

\section{Procedure}

Voor het verkrijgen van gegevens omtrent probleemgestuurd studiegedrag en toetsvoorbereiding is gebruik gemaakt van een schriftelijke vragenlijst. Deze 
is afgenomen tijdens de eerste blokperiode van studiejaar 1995-1996. De wragen hadden betrekking op het studiegedrag in het voorafgaande studiejaar 1994-1995. De resultaten zijn gerelateerd aan het toetsresultaat dat behaald is op de laatste voortgangstoets van dit voorafgaande studiejaar.

\section{Steekproeftrekking en populatie}

De respondenten betroffen een steekproef van studenten uit de jaargroepen 2,3 en 4, waarbij de vragenlijst betrekking had op hun studiegedrag in het voorgaande studiejaar als respectievelijk eerste-, tweede- en derdejaars studenten. Binnen deze jaargroepen is voor elk van de zeven afstudeerrichtingen één onderwijsgroep geselecteerd. Alle 174 studenten uit deze onderwijsgroepen zijn gevraagd de vragenlijst in te vullen. Hiervan hebben 164 studenten de vragenlijst geretourneerd (respons $94,3 \%$ ).

Bij de verwerking en bespreking van de resultaten is uitgegaan van de jaargroep waaraan studenten voor de voortgangstoets werden gerefereerd (en worden besproken als jaargroep 1,2 en 3). Dit had tot gevolg dat achteraf bleek dat in een aantal gevallen de jaargroep waarbinnen studenten onderwijs volgden, niet correspondeerde met de jaargroep waaraan deze studenten op de voortgangstoets waren gerefereerd. Er bleken namelijk 13 vijfdejaars studenten deel uit te maken van de steekproef. Deze studenten wijken af van de vierdejaars, onder andere op het gegeven dat deze studenten in principe afgestudeerd hadden kunnen zijn en ofwel studievertraging hebben opgelopen, ofwel nog (extra) onderwijs volgen. Om deze reden zijn zij buiten de analyse gelaten.

Van de resterende 151 studenten ontbreken voor 9 studenten gegevens op de derde voortgangstoets van studiejaar 1994-1995 en kunnen 11 studenten op basis van hun antwoorden op de vragenlijst niet ingedeeld worden onder éen type probleemgestuurd studiegedrag (zie analyse). Studenten ontvingen bij het retourneren van de vragenlijst een financiële vergoeding.

\section{Materialen}

\section{Probleemgestuurd studiegedrag}

Bij de ontwikkeling van een vragenlijst omtrent probleemgestuurd studiegedrag heeft een aantal uitgangspunten een rol gespeeld. De vragenlijst moest zich richten op zowel studie-activiteiten tijdens de zelfstudie als op studie- 
activiteiten tijdens de voor- en nabespreking in de onderwijsgroep. Daarnaast moesten zowel in de onderwijsgroep zichtbare studie-activiteiten als niet zichtbare denkactiviteiten deel uitmaken van de vragenlijst, omdat een groot gedeelte van de denkprocessen niet worden omgezet in waarneembaar gedrag in de onderwijsgroep (De Grave et al.; 1996). Gezien de vraagstelling diende de vragenlijst verder een globaal beeld te schetsen van studiegedrag, omdat de interesse in eerste instantie uitgaat naar het effect van studiegedrag over een langere periode in het algemeen in plaats van specifieke leereffecten ten gevolge van specifieke gedragingen.

Van globale zelfschattingen is bekend dat deze onbetrouwbaar zijn, zeker wanneer deze betrekking hebben op een langere periode (Gordon, 1991). In onderzoekssituaties naar persoonlijkheid en persoonlijkheidstrekken is het in toenemende mate gebruikelijk persoonskenmerken die worden beïnvloed door de situatie en situatiekenmerken gelijktijdig te meten. Op deze manier wordt een betrouwbaarder beeld van het daadwerkelijk gedrag verkregen (onder andere Hol, 1994).

Deze wijze van meten inspireerde tot het samenstellen van gedragsprofielen gekoppeld aan fasen van het probleemgestuurd onderwijs. Hiermee werd recht gedaan aan het interactie- effect tussen studenten en de leeromgeving en werd een globaal beeld van studiegedrag verkregen. Bovendien werd het mogelijk de neiging tot sociaal wenselijke antwoorden en HALO-effecten te verminderen. De gedragsprofielen zijn geformuleerd op basis van literatuur (De Grave, 1993; Moust et al, 1989; Schmidt, 1983) en consultatie van een panel van onderwijskundigen met ruime expertise in probleemgestuurd onderwijs $(n=6)$.

De gedragsprofielen zijn geformuleerd binnen een onderdeel van de zevensprong, waarbij zijn onderscheiden: formuleren van de probleemstelling, brainstorm en structureren, formuleren van leerdoelen, zelfstudie, rapporteren en evalueren. Voor elk van de vier typen probleemgestuurd studiegedrag (zie figuur 3.2) is een situatiebeschrijving geschreven binnen deze zes onderscheiden fasen. In figuur 3.3 zijn als voorbeeld de vier profielen voor formuleren van leerdoelen geplaatst in de structuur van figuur 3.2. De uiteindelijke vragenlijst bevatte dus 24 gedragsprofielen. 


\begin{tabular}{|c|c|c|c|}
\hline \multirow{2}{*}{\multicolumn{2}{|c|}{$\begin{array}{c}\text { Probleemgesturd } \\
\text { studiegedrag }\end{array}$}} & \multicolumn{2}{|c|}{ Component "activiteit van probleemgestuurd studiegedrag" } \\
\hline & & passief & actief \\
\hline \multirow{2}{*}{ 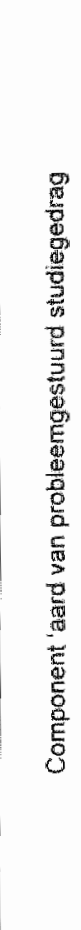 } & $\frac{\frac{g}{2}}{\frac{\pi}{\frac{\pi}{2}}}$ & 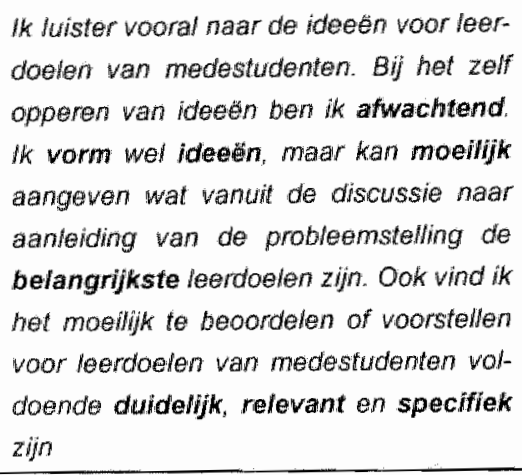 & $\begin{array}{l}\text { De ideeën voor leerdoelen die bij me } \\
\text { opkomen zeg ik. Ik whd het wel moej- } \\
\text { lijk om vamuit de discussie naar aantei- } \\
\text { ding van de probleemstelling te zeggen } \\
\text { waarover we nog leerdoelen moeten } \\
\text { maken. Ook wind ik het moeilik ze } \\
\text { werkbaar en eenduidig te formuleren } \\
\text { Mijm inbreng geeft vaak een aanleiding } \\
\text { voor medestudenten om een leerdoel } \\
\text { te specificeren of te verduidelijken }\end{array}$ \\
\hline & $\frac{0}{0}$ & $\begin{array}{l}\text { Hk luister vooral naar de voorstellen woor } \\
\text { leerdoelen van medestudenten. Ik kan } \\
\text { aangeven waarover we volgens mij leer- } \\
\text { doelen zouden moeten formuleren. Met } \\
\text { hel inbrengen van mijn ideeen ben ik } \\
\text { doorgaans wat afwachtend. Achteraf } \\
\text { blikt dan regelmatig dat de uiteindelijke } \\
\text { leerdoelsn in sterke mate overeen- } \\
\text { komen met degene die mij van belang } \\
\text { leken }\end{array}$ & $\begin{array}{l}\text { Doorgaans ben ik in staat vanuit de } \\
\text { discussie naar aanieiding van de pro- } \\
\text { bleemstelling aan te geven waarover } \\
\text { we leerdoelen moeten formweren. Dit } \\
\text { omzetten in duidelijke en werkbare } \\
\text { leerdoelen kan ik doorgaans ock. De } \\
\text { ideeern die ik op daf moment bedenk } \\
\text { breng ik over het algemeen in. De uj- } \\
\text { teirdelijke leerdoelen komen vaak in } \\
\text { sterke mate overeen met degene die } \\
\text { mij van belang leken }\end{array}$ \\
\hline
\end{tabular}

Figuur 3.3 Gedragsprofielen voor 'formuleren van leerdoelen'

Elk gedragsprofiel is door studenten gescoord op een vijfpuntsschaal, waarbij is gevraagd in welke mate studenten zich herkenden in elk van de gegeven omschrijvingen over het gehele studiejaar 1994-1995. De scores stonden voor: (1) niet tot nawwelijks, (2) enigszins, (3) behoorlijk. (4) zeer behoorlijk, (5) (nagenoeg) volledig.

\section{Toetsvoorbereiding}

In de vragenlijst zijn drie vragen opgenomen over de wijze van toetsvoorbereiding die de veronderstelde toetsvoorbereiding binnen probleemgestuurd onderwijs, dan wel de veelal waargenomen toetsvoorbereiding, globaal in kaart brengen.

Het al of niet voor de voortgangstoets toetsgericht studeren is onderzocht door middel van een situatieschets met een beschrijving van studiegedrag 
waarbij specifiek ter voorbereiding op de voortgangstoets wordt gestudeerd. Op een vijfpuntsschaal dienden studenten te scoren in welke mate zij zich herkenden in de beschrijving. Daarnaast zijn twee vragen over studietijd gesteld; een vraag naar het aantal studie-uren tijdens het blok en een vraag naar het aantal studie-uren specifiek gericht op de voortgangstoets.

\section{Voortgangstoetsresultaat}

De toetsscore betreft de goed-min-fout score die is behaald op de laatste voortgangstoets van het studiejaar waarop de vragenlijst betrekking had (studiejaar 1994-1995).

\section{Analyse}

Probleemgestuurd studiegedrag is bepaald door studenten in te delen in een type probleemgestuurd studiegedrag en het berekenen van intervalwaarden op de componenten 'aard' en 'activiteit' van probleemgestuurd studiegedrag. Voor de indeling in een typologie zijn de gemiddelden berekend over de zes profielen die een type probleemgestuurd studiegedrag representeren. Hiermee krijgt elke student vier gemiddelden waarbij studenten zijn gecategoriseerd in het type waarop zij zichzelf het hoogste gemiddelde hebben toegekend. Met deze procedure zijn 11 studenten niet gecategoriseerd in een type omdat zij op twee typen tot hetzelfde gemiddelde kwamen.

Met behulp van een one-way ANOVA is getoetst of het gemiddelde van het type waarin studenten zijn gecategoriseerd, welke de basis vormde voor de indeling, significant verschilt van de andere gemiddelden. Daarnaast is nagegaan hoeveel studenten met behulp van een discriminant analyse op basis van hun numerieke scores op de gedragsprofielen tot dezelfde typologie zouden zijn gecategoriseerd als met bovenstaande procedure.

De interval scores op de componenten 'aard' en 'activiteit' zijn bepaald op basis van het verschil tussen de som van elke dimensie van de betreffende component, tussen de wenselijke en de niet wenselijke dimensie van de component. ${ }^{5}$ De variabelen hebben een mogelijke range van -4 en +4 .

${ }^{5}$ Bij voorbeeld: om een interval score op de component sard" te berekenen zijn de gemiddelde scores op de twee typen probleemgestuurd studiegedrag die de dimensie 'oppervlakkig' bevatten, oppervlakkig passief en oppervlakkig passief, bij elkaar opgeteld. Hetzelfde is gedian voor de twee typen probleemgestuurd studiegedrag die de dimensie 'diep' bevatien, diep passicf en diep actief. Dit geeft een interval waarde op beide dimensies 'oppervlakkig" en 'diep'. Vervolgens wordt de interval score 'aard' bepaald door het verschil tussen de waarden woor 'opperwlakkig" en 'diep' te berekenen. 
Verschillen in voortgangstoetsresultaten tussen de typen probleemgestuurd studiegedrag zijn getoetst met een ANOVA. Jaargroep is (mede) oorzaak van een hoge binnen-groepen-variantie, vanwege de groei van kennis in de loop van de studie. Voor deze invloed is gecorrigeerd door jaargroep, gecodeerd tot dummy, als covariaat op te nemen in de analyse.

De verschillen tussen de typen studenten zijn getoetst met behulp van een one-way ANOVA. Post-hoc vergelijkingen tussen de groepen zijn gedaan met behulp van Tukey"s honesty significant difference.

De unieke bijdrage van probleemgestuurd studiegedrag aan voortgangstoetsresultaten is getoetst met behulp van regressieanalyse, waarbij gecorrigeerd wordt voor jaargroep en wijze van toetswoorbereiding. De volgorde van het toevoegen van de variabelen in de regressievergelijking werd in vier stappen geforceerd uitgevoerd. Als eerste werd gecorrigeerd voor groei in kennis ten gevolge van vordering met de studie. Hiervoor zullen de jaargroep 1,2 en 3 als twee dummy's opgenomen worden in de analyse ('wel/niet jaar 1' en 'wel/niet jaar 2). Vervolgens werd in de tweede stap gecorrigeerd voor het aantal uren dat tijdens het blok gemiddeld per week is gestudeerd. Daarna werd in de derde stap gecorrigeerd voor de invloed van specifiek studeren voor de voortgangstoets. De variabelen 'aantal uren studeren voor de voortgangstoets' en 'mate van specifiek gaan studeren voor de voortgangstoets' werden gelijktijdig toegevoegd aan de regressievergelijking. Als laatste worden gezamenlijk de variabelen 'aard' en 'activiteit' van probleemgestuurd studiegedrag toegevoegd. Deze werden gelijktijdig toegevoegd omdat verondersteld wordt dat ze samen het construct probleemgestuurd studiegedrag te vormen.

\section{Resultaten}

\section{Probleemgestuurd studiegedrag}

Studenten zijn gecategoriseerd in êen van de vier typen probleemgestuurd studiegedrag: degene waarop zij zichzelf de hoogste (gemiddelde) score hebben gegeven. In tabel 3.2 zijn deze gemiddelden weergegeven met bovendien de (lagere) gemiddelden op de andere drie typen. De vetgedrukte waarden betreffen het gemiddelde op de profielen van het type waarin de betreffende studenten zijn gecategoriseerd. 
Tabel 3.2 Gemiddelden op de profielen en interval variabelen aard en activiteit voor de vier typen probleemgestuurd studiegedrag

\begin{tabular}{lrrrrrrr}
\hline & $\mathrm{N}$ & diep actief & opp. actief diep passief opp. passief & aard & activiteit \\
\cline { 2 - 8 } Type-indeling & & & & & & & \\
diep actief & $59(44 \%)$ & 3.6 & 2.6 & 2.4 & 1.4 & 2.4 & 1.9 \\
opp. actief & $32(24 \%)$ & 2.5 & 3.2 & 2.2 & 1.9 & 1.6 & -0.3 \\
diep passief & $31(23 \%)$ & 2.1 & 2.4 & 3.0 & 2.1 & -0.6 & 0.7 \\
opp. passief & $11(8 \%)$ & 1.6 & 2.3 & 2.4 & 2.8 & -1.4 & -1.2 \\
\hline F-waarde & & $71.5^{*}$ & $1.3 .2^{*}$ & $18.0 *$ & $33.2 *$ & $82.2 *$ & $70.8 *$ \\
(df) & $(3 ; 129)$ & $(3 ; 129)$ & $(3 ; 129)$ & $(3 ; 129)$ & $(3 ; 129)$ & $(3 ; 129)$ \\
\hline
\end{tabular}

Voor elk van de typologieën geldt dat de gemiddelde score op de typologie warin men is ingedeeld significant hoger is dan de gemiddelde score op de overige typologieën. Het grootste deel van de studenten herkent zich in de beschrijvingen van diep actief studiegedrag (46.7\%). Er zijn slechts weinig studenten die zijn ingedeeld in de oppervlakkig passieve typologie $(8.3 \%)$.

De interval waarden op de componenten aard en activiteit verschillen significant tussen de typologieën. Post-hoc vergelijkingen met behulp van Tukey"s honesty significant difference laten zien dat deze verschillen gelden voor elk van de gemiddelden ten opzichte van elkaar. Hierbij is het overigens opvallend en tegenstrijdig dat diep passieve studenten actiever zijn dan oppenvlakkig actieve studenten $(0.7$ respectievelijk -0.3 op de component 'aard').

In tabel 3.3 wordt een vergelijking gemaakt tussen de typologie classificatie op basis van het hoogste gemiddelde ten opzichte van de classificatie met behulp van de discriminant analyse op basis van de 24 numerieke scores.

Tabel 3.3 Classificatie van type probleemgestuurd studiegedrag op basis van hoogste gemiddelde score ten opzichte van classificatie met behulp van discriminant analyse

\begin{tabular}{|c|c|c|c|c|c|c|c|c|c|}
\hline \multirow{3}{*}{$\frac{\text { Typologie }}{\text { dhep actief }}$} & \multirow{3}{*}{$\frac{N}{59}$} & \multicolumn{8}{|c|}{ Voorspelde typologie-indeling } \\
\hline & & \multicolumn{2}{|c|}{ diep actief } & \multicolumn{2}{|c|}{ opp. actief } & \multicolumn{2}{|c|}{ diep passief } & \multicolumn{2}{|c|}{ opp. passitef } \\
\hline & & 56 & $(94.9 \%)$ & 3 & $9.4 \%$ & 0 & $(0 \%)$ & 0 & $10 \%$ \\
\hline opp actief & 32 & 0 & $(0 \%)$ & 29 & $(90.6 \%)$ & 3 & $(9.4 \%)$ & 0 & $(0 \%)$ \\
\hline diep passief & 31 & 2 & $(6.5 \%)$ & 0 & $(0 \%)$ & 28 & $(90.3 \%)$ & 1 & $(3.2 \%)$ \\
\hline opp. passief & 11 & 0 & $(0 \%)$ & 0 & $(0 \%)$ & 11 & $(100 \%)$ & 0 & $(0 \%)$ \\
\hline gelik gem. & 4 & & $(25.0 \%)$ & 1 & $(25.0 \%)$ & 0 & $(0 \%)$ & 2 & $(50.0 \%)$ \\
\hline
\end{tabular}


Op basis van de 24 mumerieke scores op de gedragsprofielen zouden $93.2 \%$ van de studenten met gebruikmaking van een discriminant analyse zijn gecategoriseerd in dezelfde typologie als op basis van de gehanteerde indeling.

\section{Toetsvoorbereiding en probleemgestuurd studiegedrag}

De gemiddelden op de variabelen voor toetsvoorbereiding, aantal uren zelfstudie tijdens het blok, aantal uren zelfstudie specifiek voor de toets en de mate van specifiek studeren voor de toets zijn weergegeven in tabel 3.4 .

Tabel 3.4 Gemiddelde zelfstudietijd tijdens het blok, zelfstudietijd specifiek voor de toets en mate van specifiek studeren voor de voortgangstoets (met standaarddeviatie tussen haakjes) voor elk type probleemgestuurd studiegedrag

\begin{tabular}{|c|c|c|c|c|c|c|c|}
\hline \multirow[b]{2}{*}{ uren zelfstudie tijdens blok } & $\begin{array}{l}\text { diep actief } \\
(n=58)\end{array}$ & \multicolumn{2}{|c|}{$\begin{array}{l}\text { opp. actief } \\
(n=32)\end{array}$} & $\begin{array}{c}\text { diep passief } \\
(n=31)\end{array}$ & \multicolumn{2}{|c|}{$\begin{array}{c}\text { opp. passief } \\
(n=11)\end{array}$} & $\begin{array}{c}\text { totaal } \\
(n=132)\end{array}$ \\
\hline & $29.7(9.6)$ & 30.5 & $(7.1)$ & $28.5(7.9)$ & 26.0 & $(8.1)$ & $29.3(8.5)$ \\
\hline uren specifiek studeren & $1.3(3.0)$ & 2.1 & $(2.9)$ & $2.0(3.1)$ & 1.2 & $(\pi .2)$ & $1.7(2.9)$ \\
\hline mate van specifiek studeren & $4.3(1.2)$ & 3.7 & $(7.5)$ & $3.8 \quad(1.2)$ & 4.1 & (1.0) & $4.0(1.3)$ \\
\hline
\end{tabular}

De verschillen in zelfstudie-tijd bij de typen probleemgestuurd studiegedrag zijn niet significant, zowel niet voor het gemiddeld aantal uren zelfstudie tijdens het blok $(F(3,126)=0.892), p>0.05)$ als het aantal uren zelfstudie tex voorbereiding op de voortgangstoets $(\mathrm{F}(3,128)=0.709, \mathrm{p}>0.05)$. De typen probleemgestuurd studiegedrag verschillen eveneens niet significant in de mate van specifiek gaan studeren voor de voortgangstoets $(F(3,126)=$ $0.892, p>0.05)$. De hoge standaarddeviaties geven de indruk dat toetsvoorbereiding een persoonskenmerk is dat weinig is gerelateerd aan een type probleemgestuurd studiegedrag.

\section{Probleemgestuurd studiegedrag en toetsresultaten}

In tabel 3.5 worden de gemiddelde goed-min-fout scones (in absolute aantallen) van studenten met verschillend probleemgestuurd studiegedrag weergem geven. 
Tabel 3.5 Gemiddelde goed-min-fout score, standaarddeviatie en aantal studenten per type probleemgestuurd studiegedrag, onderverdeeld naar jaargroep

\begin{tabular}{|c|c|c|c|c|c|c|c|c|c|c|c|c|}
\hline \multirow[b]{2}{*}{ PGO-type } & \multicolumn{3}{|c|}{ jaargroep 1} & \multicolumn{3}{|c|}{ jaargroep 2} & \multicolumn{3}{|c|}{ jaargrcep 3} & \multicolumn{3}{|c|}{ totaal } \\
\hline & gem. & st dev & $n$ & gem. & st.dev & $n$ & gem. & dev & $n$ & gem. & st.dev & $\mathrm{n}$ \\
\hline diep actief & 57.3 & 12.2 & 20 & 61.8 & 18.3 & 13 & 67.2 & 20.8 & 26 & 62.6 & 18.0 & 59 \\
\hline appervlakkig actief & 39.9 & 9.9 & 9 & 58.9 & 19.0 & 7 & 65.4 & 11.9 & 16 & 56.8 & 16.9 & 32 \\
\hline diep passief & 54.8 & 16.1 & 12 & 57.0 & 27.1 & 8 & 68.9 & 16.0 & 14 & 60.4 & 198 & 31 \\
\hline oppervlakkig passief & 41.0 & 10.5 & 5 & 55.0 & 5.7 & 2 & 64.5 & 15.0 & 4 & 52.9 & 15.5 & 11 \\
\hline
\end{tabular}

Voor de totale steekproef geldt dat studenten met diep actief probleemgestururd studiegedrag gemiddeld de hoogste score behalen. Studenten met oppervlakkig passief probleemgestuurd studiegedrag behalen de laagste score. De verschillen in goed-min-fout scores over de hele steekproef (met jaargroep als dummyvariabele) zijn niet significant $(\mathbb{F}(3,132)=1.74, p=$ 0.16 ). De groepen zijn echter klein. Post-hoc vergelijkingen tussen de typen probleemgestuurd studiegedrag binnen jaargroepen, met behulp van Tukey's honesty significant difference test, leveren significante verschillen binnen jaargroep 1 tussen oppervlakkig actief en diep actief problemgestuurd studiegedrag $(F(3,42)=5.2, p=0.004)$,

Met behulp wan een regressie analyse is de invloed van probleemgestuurd studiegedrag op de toetsscore onderzocht, waarbij is gecorrigeerd voor de invloed van jaargroep en de wijze van toetsvoorbereiding. Bij deze analyse is gebruik gemaakt van de intervalwaarden op de dimensies stijl en activiteit van probleemgestuurd studiegedrag. In tabel 3.6 wordt de correlatie matrix gegeven. De dummy-variabelen voor jaargroep zijn niet opgenomen in de tabel.

Tabel 3.6 Correlatie matrix voor de variabelen toetsvoorbereiding, probleemgestuurd studiegedrag en goed-min-fout score $(n=133$ )

\begin{tabular}{|c|c|c|c|c|c|}
\hline & $\begin{array}{l}\text { Gminf } \\
\text { score }\end{array}$ & $\begin{array}{l}\text { PGO } \\
\text { activiteit }\end{array}$ & $\begin{array}{l}\text { PGO } \\
\text { aard }\end{array}$ & $\begin{array}{l}\text { studie-uren } \\
\text { tijdens blok }\end{array}$ & $\begin{array}{c}\text { specifiek stu- } \\
\text { deren VGT }\end{array}$ \\
\hline PGO activiteit & 0.22 & & & & \\
\hline PGO aard & 0.05 & $0.51 * *$ & & & \\
\hline studie-uren tijdens blok & 0.09 & -0.01 & $0.17 *$ & & \\
\hline mate van specifiek studeren VGT & $0.24 *$ & $0.47 *$ & $0.15 *$ & 0.02 & \\
\hline studie-uren woor VGT & -0.17 & -0.10 & -0.04 & 0.11 & $-0.56^{m+}$ \\
\hline
\end{tabular}

"ps0.01;:* p $\leq 0.001$ 
De betrekkelijk hoge samenhang tussen de variabelen aard en activiteit van het studiegedrag $(r=0.51)$ ondersteunt het uitgangspunt dat deze variabelen gezamenlijk het construct probleemgestuurd studiegedrag vertolken. Deze variabelen vertonen een positieve correlatie met de score op de voortgangstoets $(r=0.05, p>0.05$ en $r=0.22, p \leq 0.01)$. Het gevonden verband is echter betrekkelijk laag en voor aard niet significant.

De twee variabelen over specifiek studeren voor de voortgangstoets correleren niet met het aantal uren zelfstudie tijdens het blok $(-0.02$ en 0.11 , beide $p>0.05)$. De resultaten doen vermoeden dat er weinig samenhang is tussen studiegedrag tijdens het blok en wel of niet specifiek gaan studeren voor de voortgangstoets. Als zodlanig lijkt het erop dat specifiek gaan studeren voor de voortgangstoets een aparte vorm van toetsvoorbereiding betreft die los staat van studeergedrag tijdens het blok. In overeenstemming met de verwachting hangen de mate van specifiek studeren voor de voortgangstoets en het aantal uren specifiek studeren voor de toets betrekkelijk sterk samen ( $r=$ $0.56, \mathrm{p} \leq 0.001)$.

In tabel 3.7 worden de resultaten gegeven van de regressie analyse per stap volgens de in de analyse beschreven procedure.

Tabel 3.7 Regressie gewichten met de goed-min-fout als afhankelijke variabele en jaargroep, studietijd, toetsvoorbereiding en probleemgestuurd studiegedrag als onafhankelijke variabelen, in geforceerde volgorde uitgevoerd $(n=132)$

\begin{tabular}{|c|c|c|c|c|c|c|}
\hline & $\mathbb{R}^{2}$ & B & se $\mathbb{B}$ & $\beta$ & $\pi$ & sign: toename $\mathbb{R}^{2}$ \\
\hline 1 Jaargroep & 0.123 & & & & & \\
\hline 1 & & -12.56 & 3.82 & 0.34 & $-3.29 *$ & \\
\hline 2 & & -7.28 & 3.77 & -0.17 & $-1.93 *$ & \\
\hline 2 Aantal studie-uren tijdens blok & 0.125 & -0.01 & 0.19 & -0.00 & -0.05 & \\
\hline 3 Toetsvoorbereiding & 0.146 & & & & & $F=1.54$ \\
\hline a specifielk studeren & & 0.08 & 0.63 & 0.01 & 0.13 & \\
\hline b uren specifiek studeren & & 1.91 & 1.41 & 0.14 & 1.36 & \\
\hline 4 Probleemgestuurd studiegedrag & 0.188 & & & & & $F=3.18^{\circ}$ \\
\hline a aard & & -1.08 & 0.98 & -0.11 & -1.10 & \\
\hline b activiteit & & 3.18 & 1.27 & 0.23 & $2.52^{m *}$ & \\
\hline (Constant) & & 57.09 & 8.95 & & 6.38 & \\
\hline
\end{tabular}

De variabelen 'jaargroep' en 'hoeveelheid studie-uren tijdens de blokperiode' verklaren samen ruim $12 \%$ van de variantie in de goed-min-fout score op de 
voortgangstoets. Toevoeging van de variabelen voor gerichte toetsvoorbereiding: de mate waarin specifiek voor de toets wordt gestudeerd en het aantal uren zelfstudie dat specifiek voor de voortgangstoets wordt gestudeerd, verklaren samen bijna $15 \%$ van de variantie in de goed-min-fout score op de voortgangstoets. Deze verbetering van de verklaarde variantie is niet significant $(\mathrm{F}(3,2,5,127)=1.54, \mathrm{p}>0.05)$. Toevoeging van de variabelen probleemgestuurd studiegedrag, aard en activiteit, leveren een verklaring van $19 \%$ van de variantie. Het toevoegen van deze variabelen levert een significante verbetering in de verklaring van het model $(\mathrm{F}(5,2,7,125)=3.18, \mathrm{p} \leq$ $0.05)$.

\section{Discussie en conclusie}

In het beschreven onderzoek staat de invloed van probleemgestuurd studiegedrag op voortgangstoetsresultaten centraal. Probleemgestuurd studiegedrag is op een niet eerder gebruikte wijze in kaart gebracht. Zowel het onderscheiden van twee componenten van probleemgestuurd studiegedrag -activiteit en aard van het studiegedrag. met daaruit voortkomend vier typen probleemgestuurd studiegedrag, als het meten van studiegedrag met behulp van gedragsprofielen die zijn gekoppeld aan een onderdeel van het onderwijsleerproces, zijn niet eerder in deze vorm toegepast. Er blijkt een duidelijk onderscheid tussen scores op het type probleemgestuurd studiegedrag waarin studenten worden ingedeeld en scores op de overige typen. Ook ten aanzien van de hoogte van de interval variabelen op de componenten van probleemgestuurd studiegedrag geldt een duidelijk onderscheid tussen de typen. Wel is het vreemd dat studenten met de actieve dimensie van activiteit "oppervlakkig actief studiegedrag' minder actief zijn dan studenten met de passieve dimensie 'diep passief studiegedrag'. Het lijkt erop dat de component 'aard' een sterkere invloed heeft op het gemiddelde dan de component 'activiteit'. Mogelijke verklaringen hiervoor zijn dat studenten zich sterker vereenzelvigen met gedragingen die de aard van het gedrag weergeven dan met gedragingen die de 'activiteit' van het gedrag operationaliseren, of wordt veroorzaakt doordat de operationalisering van 'aard' sterker is vertegenwoordigd in de formulering van de profielen. 
Met betrekking tot de verschillende vraagstellingen kan een aantal conclusies worden getrokken.

Probleemgestuturd studiegedrag. Verreweg het grootste gedeelte van de studenten kan worden irgedeeld in het type diep actief probleemgestuurd studiegedrag. Dit is positief gezien het feit dat dit het meest wenselijke type probleemgestuurd studiegedrag betreft. Dit ondersteunt de conclusies van Coles (1985), Hilliard (1995) en Newble en Clarke (1986) dat studenten als gevolg van probleemgestuurd onderwijs in sterke(re) mate worden aangestuurd tot diepte verwerking in hun studie-activiteiten. In beide onderzoeken kwamen de auteurs op basis van vergelijking met traditionele curricula tot de conclusie dat studenten wit een probleemgestuurd curriculum sterker geneigd zijn tot diepte verwerking. Slechts zeer weinig studenten komen tot het minst wenselijke type studiegedrag, oppervlakkig passief. Sociaal wenselijk antwoorden kan hier debet aan zijn. Toch is met het ontwikkelde instrument gezocht naar een alternatief voor globale zelfbeoordelingen van onder nomen gedrag met behulp van losse items waarvan bekend is dat deze slechte voorspellers zijn van feitelijk gedrag (Gordon, 1991). Minder wenselijk gedrag is in de ontwikkelde vragenlijst verpakt" in de context van concrete gedragsprofielen. Bovendien hebben alle studenten zowel wenselijke als. minder wenselijke profielen beantwoord. Wellicht zijn de absolute scores aan de hoge en daarmee aan de positieve kant, maar hoogstwaarschijnlijk wordt hiermee in elk geval tot een correcte rangorde van meer of minder wenselijk probleemgestuurd studiegedrag tussen studenten gekomen. Het eerder vermelde duidelijke onderscheid van gemiddelden op de eigen profielen ten opzichte van de anderen, zowel op de (sociaal) gewenste als minder (sociaal) gewenste profielen, ondersteunt en bepaalde betrouwbaarheid. De bevin ding dat oppervlakkig actieve studenten minder actief zijn dan diep passieve studenten geeft wel aanleiding tot nader onderzoek naar de gehanteerde vragenlijst.

Typen probleemgestuurd studiegedrag en toetsvoorbereiding. De wijze van toetswoorbereiding is niet duidelijk gerelateerd aan een type probleemgestuurd studiegedrag. Ondanks de aanwijzingen voor sterker toetsgerichte voorbereiding door studenten met oppervlakkig actief en diep passief studiegedrag, zonder significante verschillen, lijkt er eerder sprake van een persoonsgebonden variatie in toetsvoorbereiding dan variatie in toetsvoorbereiding die (al of niet) in het verlengde ligt van de studiemactiviteiten tijdens de 
blokperiode. Hierbij dient opgemerkt te worden dat de variabelen toetsvoorbereiding tamelijk robuust zijn gemeten. De mate van specifiek studeren voor de voortgangstoets is onderzocht met slechts éen globale vraag. Het aantal studie-uren tijdens het blok en het aantal studie-uren voor de voortgangstoets zijn op basis van retrospectieve schattingen, die tamelijk onbetrouwbaar worden gevonden (Crombag, De Gruijter, Van de Ende \& Vos, 1980). Moust (1993) vindt echter correlaties van 0.62 waarmee verondersteld kan worden dat de rangordening tussen studenten voor wat betreft meer of minder studeren enige relevante informatie oplevert. Onderzoek met focusgroepen bracht wel aan het licht dat bij sommige studenten gebrek aan tijd in hun laatste voorbereiding op toetsen kan leiden tot memoriserend leren (Lindemamn \& Cabret, 1995).

De veronderstelling van Van der Vleuten, Scherpbier, et al. (1996) dat er voor de Maastrichtse voortgangstoets niet wordt gestudeerd lijkt niet geheel terecht. Er wordt wel voor de voortgangstoets gestudeerd. In hoeverre dit gaat ten koste van activiteiten voor de onderwijsgroep is op basis van dit onderzoek niet te zeggen. Bemoedigend is wel dat in McMaster na invoering van een vergelijkbare toets als de voortgangstoets, studenten rapporteren dat de toets geen invloed heeft op studie-activiteiten voor de onderwijsgroep (Blake et al., 1995). Bovendien werden door hen geen verschuivingen gevonden in de voorkeursleerstijl: de angst voor verandering in de richting van memoriserend leren bleek ongegrond.

Typen probleemgestuurd studiegedrag en toetsresultaten. Naast de bevinding dat de wijze van toetswoorbereiding betrekkelijk los staat van de wijze waarop in de onderwijsgroepen en tijdens de zelfstudie met probleemgestuurd onderwijs wordt omgegaan, blijken ook de toetsresultaten nauwelijks groepsgewijs gerelateerd met typen probleemgestuurd studiegedrag. Opnieuw zijn er slechts tendensen ten gunste van bepaalde typen studiegedrag, ditmaal wel met significante verschillen in het eerste studiejaar. Deze tendensen zijn overigens wel in overeenstemming met de vooraf geformuleerde verwachtingen: studenten met het meest wenselijke type van probleemgestuurd studiegedrag, de diep actieve studenten, behalen de hoogste studieresultaten en studenten met het minst wenselijke type studiegedrag, oppervlakkig passief, zijn degenen met de laagste studieresultaten. Voorzichtig kan worden geconcludeerd dat, in overeenstemming met de veronderstelling van Swanson et al. (1991) variatie tussen studenten in hun vaardigheden om zelfgestuurd 
(ofwel probleemgestuurd) te leren, leidt tot variaties in leereffect, hoewel op basis wan het design van het in dit hoofdstuk beschreven studie geen conclusies zijn te trekken ten aanzien van causaliteit.

Probleemgestuurd studiegedrag, toetswoorbereiding en studieresultaten. Het. aantal uren dat er voor de voortgangstoets wordt gestudeerd is negatief gecorreleerd met zowel probleemgestuurd studiegedrag als met de toetsscore. De bevindingen van Dickinson en O'Connell (1990) vormden al eerder een aanwijzing dat niet zozeer de tijdsinspanning, maar meer de aard van de inspanning van invloed is op studieresultatem en worden in deze studie bevestigd. Deze auteurs vonden eveneens geen relatie tussen de totale studietijd en toetsresultaten. Wel wonden zij een relatie tussen toetsresultaten en de tijd die werd besteed aan organiseren. Hun operationalisering van organiseren in de vorm van verwerkingsactiviteiten als in eigen woorden vertalen", 'stmuctuur in de tekst zoeken", 'begrip zoeken', etc. vertoont overeenkomster met diepte verwerking.

Studieresultaten vertonen slechts een zwak positief verband met de "activiteit' component van probleemgestuurd studiegedrag en geen correlatie met de 'aard' component van probleemgestuurd studiegedrag.

De toevoeging van toetsvoorbereidende variabelen in de vorm van het aantal uren specifiek studeren en mate van specifiek studeren leveren in de hier beschreven studie dan ook nauwelijks een bijdrage aan een betere verklaring van toetsresultaten. Wel lijkt er na correctie voor toetsvoorbereidende variabelen, een positieve invloed uit te gaan van probleemgestuurd studiegedrag. op basis van in eerdere studies herhaaldelijk gevonden positieve effecten op toetsresultaten van diepte verwerkingsactiviteiten tijdens zelfstudie fonder andere Hilliand, 1995; Van Rossum 8 Schenk, 1984; Vermunt, 1992), lag een positieve invloed van de "aard" van studiegedrag meer in de lijn van de verwachtingen. Temeer omdat deze tendens ook binnen probleemgestuurd onderwijs werd gevonden in de studie van Van Berkel et al. (1995).

Het positieve verband tussen activiteit en studieresultaten lijkt niet in overeenstemming met het onderzoek van Moust et al. (1986). Hier werden geen aanwijzingen gevonden voor een positieve invloed van verbale participatie tijdens de brainstorm op het onthouden van kermis. Hun veronderstelling dat elaboraties die niet zichtbaar zijn, maar wel worden gedaan in het hoofd van studenten, kan wellicht een verklaring vormen. Het onderzoek van De Grave et al. (1996) heeft inmiddels laten zien dat een groot gedeelte aan 
(denk)activiteiten naar aanleiding van de discussie in de onderwijsgroep onzichtbaar blijft. Overigens heeft hun onderzoek slechts betrekking op slechts een onderdeel van probleengestuurd onderwijs. Terwijl eerder onderzoek met name wijst in de richting van een positieve invloed van de aard in plaats van de activiteit van probleemgestuurd studiegedrag lijkt in de in dit hoofdstuk beschreven studie eerder het tegenovergestelde het geval: de invloed van de activiteit component lijkt sterker dan de invloed van de aard component.

Bij de vergelijking van de resultaten uit dit hoofdstuk met de genoemde studies wordt een bepaalde samenhang tussen probleemgestuurd gedrag in de onderwijsgroep en tijdens zelfstudie, en leerstijlen (of leerstrategieën) tijdens de zelfstudie verondersteld. Dit blijkt inderdaad het geval. In een inmiddels verrichte vergelijking tussen de scores op schalen omtrent verwerkingsactiviteiten van Vermunt met de vragenlijst omtrent probleemgestuurd studiegedrag blijkt dat studenten met diep probleemgestuurd studiegedrag in de onderwijsgroep, ook degenen zijn die zich tijdens de zelfstudie meer richten op relateren, structureren, kritisch kijken naar de leerstof en concreet maken van de leerstof (Van Til, Van der Vleuten en Van Berkel, 1997, november). Bovendien zijn degenen die in hun studiegedrag minder actief gebruik maken van de mogelijkheden van probleemgestuurd onderwijs en zich daarmee minder laten sturen door de onderwijsgroep, ook degenen die hoger scoren op zelfsturing. Wellicht vormt vervolgens de actieve opstelling, en daarmee de gebruikmaking van mogelijkheden van de onderwijsgroep bij alle fasen van het leerproces, zowel bij het activeren van voorkennis, het construeren van kennis (-netwerken) en het toetsen van (nieuwe) kennis, vooral de meerwaarde. De suggestie van Meyer (1991) en Lonka en Lindblom-Ylänne (1996) dat misschien juist de combinatie van verschillende gedragingen de toetsresultaten beinvloeden sluit hierop aan. Hier bovenop speelt een rol dat in dit geval kennis niet is gemeten op taakniveau of cursusniveau, maar is gemeten met de voortgangstoets, welke beoogt lange termijn kennis te meten op het eindniveau van een studie.

Het is dan ook bemoedigend dat de twee variabelen voor probleemgestuurd studiegedrag een significante verbetering geven in het verklaren van variantie in studieresultaten, waarbij met een geringe selectie van variabelen voor het in kaart brengen van studie-activiteiten in het in dit hoofdstuk beschreven onderzoek bijna $19 \%$ variantie wordt verklaard. Tegen de achtergrond van 
een studie waarin met een veel groter aantal variabelen slechts $50 \%$ werd verklaard is dit percentage niet gering (Meerum Terwogt-Kouwenhoven, 1990).

Over het toetsen van kennis met behulp van de voortgangstoets in relatie tot probleemgestuurd studiegedrag kan hier een aantal conclusies worden getrokken. Allereerst blijkt dat gewenst probleemgestuurd studiegedrag, met deze globale wijze van meten, een positieve significante bijdrage levert aan voortgangstoets resultaten. Studie-activiteiten waartoe studenten worden geactiveerd in het onderwijs komen positief tot uitdrukking in de toetsscore. Dit maakt het de moeite waard om het ontwikkelen van instrumenten die probleemgestuurd studiegedrag, meten (als concept van activiteiten zowel in de onderwijsgroep als tijdens zelfstudie) verder ter hand te nemen.

Daarnaast blijkt de meerwaarde van gerichte toetsvoorbereiding die ongewenst is volgens de onderwijskundige doelstelling van de toets, een geringe verbetering maar geen significante verbetering van voortgangstoetsresultaten op te leveren. Hoewel het dus lijkt dat er toch enige sturing uitgaat van de voortgangstoets in de vorm van toetsgerichte activiteiten, lijkt het erop dat deze geen of nauwelijks invloed hebben op toetsresultaten. 


\section{Regelmaat van studeren: een studie naar de regelmaat van studeren tijdens een blokperiode en de invloed op toetsresultaten ${ }^{6}$}

In dit vierde hoofdstuk wordt een studie beschreven waarin is onderzocht hoe regelmatig de spreiding van studie-activiteiten is binnen een blokperiode. Tevens is nagegaan in hoeverre de binnen probleemgestuurd ondenwijs veronderstelde wijze van studeren, regelmatige studie-activiteiten door gespreide voorbereiding van de onderwijsgroepsbijeenkomsten, is gerelateerd aan toetsresultaten. De resultaten van de hier gepresenteerde studie zijn gebaseerd op een tijdschrijfonderzoek waaraan is deelgenomen door 70 eerstejaars studenten Gezondheidswetenschappen in de vierde blokperiode van studiejaar 1995 1996.

\section{Inleiding en probleemstelling}

In het onderwijs bestaat een hechte relatie tussen de studieomgeving en het studeergedrag dat studenten vertonen (Van der Drift \& Vos, 1987). Voor traditioneel onderwijs betekent dit vaak dat studenten aan het begin van een onderwijsperiode relatief weinig tijd aan de stuclie besteden en dat bij het naderen van toetsen een duidelijke stijging in het aantal studie-uren optreedt. De tijd die besteed wordt aan toetsvoorbereiding gaat op dat moment ten koste van andere onderwijsactiviteiten (Van der Drift \& Vos, 1987).

Bij probleemgestuurd onderwijs wordt ernaar gestreefd het curriculum zodanig in te richten dat dit leidt tot zelfsturend studiegedrag (self-directed. learning). De motivatie die voortdurend uitgaat van de onderwijsgroep leidt

6 Een gedelte wan dit onderzok is gepresenteend thidens het Gezond Onderwis Congres (GOC-6) te Veldhoven, 1996 (Van Til, Van der Vleuten \& Van Berkel, 1997 b) 
hierbij theoretisch tot een over de onderwijsperiode gespreide studielast (Barrows \& Tamblyn, 1980; Norman \& Schmidt, 1992; Schmidt, 1983).

De kennis die wordt opgedaan met de activiteiten in en voor de onderwijsgroep moet daarmee in principe een voldoende voorbereiding zijn om toetsen te kunnen halen. De tweewekelijkse programmering van de bijeenkomsten stuurt daarmee aan op een regelmatige over een blokperiode gespreide studiebelasting. Indien bij studenten de indruk bestat dat de onderwijsgroepsactiviteiten niet voldoende aansluiten en voorbereiden op de toetsen zullen zij datgene gaan doen waarmee zij verwachten wel voldoende te zijn voorbereid op de toets. Bij het toetsen van kennis zijn ten aanzien van de regelmatige spreiding van studie-activiteiten twee zaken van belang. De toets dient aan te sluiten op de leeractiviteiten die van studenten wordt verlangd. Met andere woorden, studenten dienen te ervaren dat het regelmatig spreiden van studie-activiteiten voor onderwijsgroepen leidt tot betere studieresultaten. Wanneer studenten ervaren dat sterk toetsgericht studeren meer effect heeft, zullen zij hun studie-activiteiten hoogst waarschijnlijk hieraan aanpassen. De voortgangstoets is in principe zodanig opgezet dat dit niet mogelijk is, omdat de toetsafname theoretisch niet interfereert met de studie-activiteiten voor de onderwijsgroep. De correctheid van deze veronderstelling, dat de toets aan de ene kant niet interfereert met studie-activiteiten voor de onderwijsgroep en aan de andere kant de regelmatige spreiding van studie-activiteiten beloont, staat centraal in de probleemstelling van dit hoofdstuk, welke luidt: "hoe is de verdeling van studie-activiteiten binnen een blokperiode en in. hoeverre is een gelijkmatige spreiding hieruan gerelateerd aan resultaten op de voortgangstoets?"

\section{Achtergrond regelmaat van studie-activiteiten in samenhang met studieresulta- ten}

Uit de tijdschrijfonderzoeken van Van der Drift en Vos (1987) is gebleken dat studenten gemiddeld maximaal zeven uur (netto) per dag in staat zijn om te studeren. Om deze maximale studietijd, ook wel belastbaarheid genoemd, optimaal te benutten moeten studenten worden gestimuleerd gespreid over een onderwijsperiode te studeren. Immers, een algemeen gegeven van de onderwijspraktijk is dat studenten de neiging hebben hun studie-activiteiten uit te stellen. Om dit te voorkomen moeten studenten voortdurend vanuit het onderwijs geprikkeld worden. Volgens Van der Drift en Vos is de inspanning 
die studenten leveren rechtstreeks afhankelijk van de prestaties die docenten verlangen.

Schouwenburg (1994) heeft uitgebreid onderzoek gedaan naar de neiging van studenten om hun studie-activiteiten uit te stellen. Volgens haar is het uitstelgedrag de consequentie van een voortdurende afweging tussen twee gedragsalternatieven, in dit geval 'studeren' of 'iets leuks doen'. Afhankelijk van de waarde die aan de alternatieven wordt gehecht wordt tot één van de activiteiten overgegaan. Centraal in haar theorie staat het gegeven dat de subjectieve waarde die aan een doel gehecht wordt een persoonsgebonden inschatting is welke over het algemeen afneemt naarmate deze verder in de toekomst ligt. Bij deze inschatting spelen persoonlijkheid en studie-motivatie een rol. Korte termijn doelen (bijwoorbeeld televisie kijken) moeten het veelal afleggen tegen lange termijn doelen (een tentamen halen).

In een aantal Nederlandse studies naar studie-activiteiten worden de volgende factoren gevonden die samenhangen met het regelmatig verrichten van studie-activiteiten en hun invloed op studiesucces.

Variabelen die in het onderzoek van Schouwenburg (1994) blijken bij te dragen aan het voorspellen van studiesucces zijn: 'lage werkdiscipline' (niet hard genoeg, onsystematisch en bij vlagen werken'), 'kunnen plannen' (de tijd doelmatig kunnen indelen en gebruiken, leertaken goed organiseren en werk op tijd af hebben) en 'zelfbeheersing' (jezelf in de hand hebben, jezelf tot minder leuke maar nuttige activiteiten kunnen aanzetten, met jezelf afspraken kunnen maken over de voortgang van het werk, jezelf kunnen belonen en bestraffen). $\mathrm{Zij}$ was in staat 40 tot $50 \%$ van studiesucces te voorspellen, gebruik makend van een groot aantal variabelen waar bovengenoemde variabelen deel van uitmaakten.

Meerum Terwogt-Kouwenhoven (1990) is met een groot aantal variabelen in staat slechts een relatief laag percentage van studiesucces te verklaren, rond de 40-45\%. Studiesucces werd door haar gedefinieerd als aantal afgelegde tentamens, puntentotaal en propedeuse-resultaat. De afwezigheid van planningsproblemen is én van de variabelen die in meerdere cohorten een significante bijdrage leveren in het voorspellen van de variabelen voor studiesucces. Studenten met extreme scores op schalen omtrent 'planning en organisatie’ presteren duidelijk beter dan de totale groep. Goede planners zijn vooral consciëntieuzer, werken regelmatiger, volgen meer colleges, besteden meer tijd aan de voorbereiding van hun tentamens en bereiden hun tentamens 
ook beter woor. Haar conclusie is dat studiesucces meer lijkt toe te schrijven aan inzet dan aan intellectuele uitrusting of bepaalde persoonlijkheidskenmerken.

Een vergelijkbare conclusie wordt getrokken door Jansen (1996): inzet, tijdsbesteding en planningsgedrag zijn variabelen die in haar onderzoek een samenhang vertonen met studievoortgang en studiesucces. Studiesucces kan echter volgens haar worden toegeschreven aan de student, maar ook aan de docent. Schouwenburg (1994) noemt dan ook als verklaring voor de relatief lage voorspellende waarde van het grote aantal variabelen met studentenkenmerken de kwaliteit van het onderwijs.

Planmatig werken en daarmee mede de spreiding van activiteiten zijn factoren die bij alle drie de bovengenoemde auteurs van invloed lijken op studieprestaties. De spreiding van studie-activiteiten is het sterkst te beïnvloeden met de programmering van toetsen.

Jansen (1996) concludeert, op basis van een vergelijking van zes studierichtingen, dat met een betere spreiding van de studielast en de tentamens docenten de studievoortgang van studenten positief kunnen beïnvloeden. Curricula waarin tentamens meer gespreid zijn over het jaar, curricula waarin herkansingen minder gespreid zijn over het jaar (concurrentie reguliere onderwijsaanbod en eerste kans tentamens), en curricula waarin minder vakken parallel geroosterd zijn laten een positief effect zien op de studievoortgang van studenten.

Een illustratief voorbeeld hiervan is de wijziging in het examenreglement van de Groningse Medische Faculteit (Cohen-Schotanus, 1994). Vergroting van het aantal mogelijkheden tot herkansing en vermindering van het aantal momenten waarop zak-slaag beslissingen worden genomen resulteerde in het uitstellen van de deelname aan examens. De gevolgen hiervan waren, naast een afname van de tijd die wordt besteed aan de studie, een forse afname van de nominale rendementen. Met de wijziging van het examenreglement werden studenten niet gedwongen het lange termijn doel -een tentamen halen- tot een korte termijn doel te maken.

Bij probleemgestuurd onderwijs brengen de onderwijsgroepsbijeenkomsten met zich mee dat wanneer studenten hier actief aan deelnemen (en deze actief voorbereiden) hun studie-activiteiten in principe betrekkelijk gespreid over een blokperiode plaatsvinden. De onderlinge betrokkenheid en sociale controle stimuleren tot studie-activiteiten. Deze aaneengeschakelde voorbe- 
reiding van de onderwijsgroepen maakt dat studenten automatisch hun kennis zien toenemen (Van der Vleuten, Scherpbier, et al , 1996). Bovendien wordt gepretendeerd dat het onderwijs zodanig is ingericht dat dit leidt tot leeractiviteiten die een sterker cognitief netwerk bij studenten tot gevolg hebben (Norman 8; Regehr, 1994; Schmidt, 1993; zie hoofdstuk 1). Studenten zouden met name beter in staat zijn zich de opgedane kennis later nog te herinneren en beter in staat zijn deze in andere situaties toe te passen (Barrows \& Tamblyn, 1980 ).

De voortgangstoets is speciaal afgestemd op probleemgestuurd onderwijs. De nadruk van de toets ligt op het onafhankelijk van het tijdens het blok gevolg. de onderwijs longitudinaal toetsen van kennis. Het ontbreken van de directe koppeling tussen het gevolgde onderwijs en de toetsafname voorkomt (of veronderstelt te voorkomen) dat studenten zeer gericht op het laatste moment zich gaan voorbereiden op de toets ten koste van de overige studieactiviteiten (Van der Vleuten, Scherpbier, et al, 1996). De toets richt zich niet op het directe leereffect van het blokonderwijs, maar op de kennis die ook na afloop van de blokperioden is blijven hangen dan wel op een andere manier is verworven. Het is dan ook de bedoeling dat het zwaartepunt van de vragen ligt op items die vragen naar lange termijn kennis (Van der Vleuten, Verwijnen \& Wijnen, 1996).

De lange termijn effecten van onderwijs zijn in een uitgebreid review artikel van Semb en Ellis (1994) samengevat. De auteurs concluderen dat in de meeste studies geen effect wordt gevonden van verschillende instructiestrategieën op de hoeveelheid kennis die op lange termijn is onthouden. Uitzondering hierop vormen studies waarin studenten op een andere beduidend actievere wijze betrokken zijn bij het onderwijs. Bijwoorbeeld in de vorm van het zelf opzetten, witvoeren en analyseren van een onderzoek voor het aanleren onderzoeksmethodologie (Conway, Cohen \& Stanhope, 1991) of het deelnemen aan een veldexcursie in het kader van geografisch onderwijs (Specht \& Sandlin, 1991).

Ook bij probleemgestuurd onderwijs zijn studenten actiever betrokken bij het onderwijs. Toch blijken bij vergelijkingen tussen traditionele en probleemgestuurde curricula kennisniveauverschillen ten gunste van traditionele curricula (Albanese 8 Mitchel, 1992). Op het 'basic science" gedeelte van het Amerikaanse NBME artsexamen worden in zes van de tien studies hogere scores gevonden, waarbij de scores van de traditionele curricula in drie 
studies significant hoger waren. In de meta-analyse van Vernon en Blake (1993) worden geen verschillen gevonden op feitenkennis en klinische kennis, maar wordt ook een verschil ten gunste van traditionele curricula gevonden op het Amerikaanse NBME artsexamen.

In Nederland is het kennisniveau van geneeskunde studenten van zowel traditionele als probleemgestuurde medische faculteiten met elkaar vergeleken met een voortgangstoets. Hoewel de studenten uit een probleemgestuurd curriculum zich minder zeker voelen over hun kennis (Post \& Drop, 1990), worden er, gemeten met een voortgangstoets, aan het einde van de studie geen kennisverschillen gevonden (Verwijnen, Van der Vleuten \& Imbos, 1987; Van der Vleuten, Verwijnen, Holdrinet, Oeseburg, Bulte \& Leunissen, 1996).

In een eerdere studie blijken volgens probleemgestuurd onderwijs wenselijke studie-activiteiten tijdens zelfstudie en tijdens de onderwijsgroep gerelateerd aan prestaties op de voortgangstoets (Van Til, Van der Vleuten \& Van Berkel, 1.997a; zie ook hoofdstuk 3). Studenten die op een actievere wijze gebruik maken van de onderwijsgroep, in de vorm van uitleg geven en vragen, een actieve rol spelen in de brainstorm, etc., hebben hogere toetsresultaten. Ook de aard van de studie-activiteiten in en voor de onderwijsgroepsbijeenkomsten lijken een rol te spelen. Wanneer zij sterker neigen naar het zoeken van verbanden, zijn gericht op het vinden van praktische voorbeelden, zich kritisch afvragen of zij het begrijpen, etc., blijkt dit positief gerelateerd aan hun voortgangstoetsscore. Hun probleemgestuurd studiegedrag is echter ook gerelateerd aan de wijze waarop zij zich voorbereiden op toetsen.

\section{Vraagstellingen en veronderstellingen}

Zoals gezegd bedraagt de maximale belastbaarheid van studenten volgens Van der Drift en Vos (1987) gemiddeld zeven uren netto per dag. De aaneengeschakelde voorbereiding van de onderwijsgroepen maakt dat studenten bij probleerngestuurd onderwijs in principe gespreid over een blokperiode studeren. De vraag is of het huidige probleemgestuurde curriculum met de huidige programmering van toetsen bij de Faculteit der Gezondheidswetenschappen leidt tot regelmatig gespreide studie-activiteiten. Dit is onderwerp van de eerste vraagstelling.

1. Hoeveel tijd besteden studenten tijdens een blokperiode aan onderwijsactiviteiten en aan zelfstudietijd in de afzonderlijke weken van het blok? 
Hierbij wordt verondersteld dat het probleemgestuurde karakter van het onderwijs met de huidige blokindeling, programmering van onderwijsactiviteiten en programmering van toetsen slechts een beperkte stijging van zelfstudietijd wordt waargenomen voorafgaande aan een toets.

Door de voortdurende stimulans die uitgaat van de onderwijsgroep vinden de onderwijsactiviteiten theoretisch niet alleen regelmatiger plaats, maar worden studenten bovendien gemotiveerd tot studie-activiteiten en wordt daarmee optimaler gebruik gemaakt van de maximale belastbaarheid van studenten. Deze veronderstelling wordt onderzocht met de volgende vraagstelling.

2. Wat is de samenhang tussen de regelmaat van de spreiding van studieactiviteiten en de totale hoeveelheid studietijd van studenten?

Volgens Van der Vleuten, Verwijnen en Wijnen (1996) leidt de aaneengeschakelde voorbereiding van de onderwijsgroepen ertoe dat studenten automatisch hun kennis zien toenemen. Dit zou betekenen dat studenten met een regelmatiger spreiding van studie-activiteiten niet alleen in verhouding tijdens het blok meer tijd (kunnen) besteden aan hun studie. Bovendien zal naar verwachting de noodzaak om vlak voor de toetsafname in grote mate extra te gaan studeren minder sterk zijn.

De nadruk van de voortgangstoets ligt op het onafhankelijk van het tijdens het blok gevolgde onderwijs longitudinaal toetsen van kennis. Dit curriculum onafhankelijk toetsen van kennis wat wil voorkomen dat studenten zeer gericht pas op het laatste moment gaan studeren (Van der Vleuten, Verwijnen \& Wijnen, 1996). Bij de Faculteit der Gezondheidswetenschappen vindt kennistoetsing echter niet alleen plaats met behulp van voortgangstoetsen, maar aok met behulp van bloktoetsen. In tegenstelling tot de voortgangstoets heeft de bloktoets wel een directe koppeling met het (net) gevolgde onderwijs. Met de bloktoets wordt een afgebakend kennisdomein getoetst dat in de voorgaande onderwijsperiode is behandeld (Van Berkel et al., 1995; zie ook hoofdstuk 1). Dit maakt dat de sturing die uitgaat van de bloktoets kan afwijken van de sturing uitgaande van de voortgangstoets. In hoeverre deze veronderstelling correct is wordt onderzocht met de volgende vraagstelling.

3. Wat is de samenhang tussen een regelmatige spreiding van studie-activiteiten en de hoeveelheid toetsgerichte voorbereiding voor de blok- en voortgangstoets en is hierbij onderscheid tussen de beide toetsen?

In principe zouden studenten bij een regelmatige voorbereiding van de onderwijsgroepen in hun voorbereiding op de bloktoets kunnen volstaan met 
een terugblik op het blok. Bijwoorbeeld met het terugblikken op blokdoelstellingen, het blokthema, het globaal bekijken van tijdens het blok gemaakte aantekeningen en het zoeken naar samenhang tussen taken. Deze vorm van toetsvoorbereiding zal een geringe toename van studietijd tot gevolg hebben dan wanneer vlak voor de toets nog moeten worden gestart met studeren. Naar verwachting zal het bij een bloktoets met een afgebakend te toetsen kennisdomein eenvoudiger zijn (of lijken) om zich op het laatste moment zeer gericht woor te bereiden op de toets dan bij de voortgangstoets.

Een ander aspect is dat het onderwijs zodanig is ingericht dat dit uitnodigt tot leeractiviteiten die een sterker cognitief netwerk bij studenten tot gevolg hebben (Norman \& Regehr, 1994; Schmidt, 1993; zie hoofdstuk 1). De studie-activiteiten tijdens de zelfstudie, al of niet regelmatig, maken onderdeel uit van de fasen van het onderwijsleerproces. De zelfstudie komt voort uit de voorbespreking van de taken en wordt achteraf getoetst aan de bevindingen van medestudenten in de rapportage tijdens de onderwijsgroep. Het doorlopen van het onderwijsleerproces draagt bij aan de kennisverwerking. In de studie naar probleemgestuurd studiegedrag zijn aan deze activiteiten de dimensies 'aard' en 'activiteit' onderscheiden (Van Til, Van der Vleuten \&s Van Berkel, 1997a; zie ook hoofdstuk 3). De samenhang tussen de regelmaat van spreiding van studie-activiteiten met de manier waarop deze tot uitdrukking worden gebracht in de onderwijsgroep staat centraal in de volgende vraagstelling.

4. Wat is de samenhang tussen een regelmatige spreiding van studie-activiteiten met de aard en activiteit van probleemgestuurd studiegedrag? Studenten studeren tijdens een blokperiode bij voorkeur niet alleen regelmatig, maar zijn bovendien betrokken bij de activiteiten in de onderwijsgroep. Het lijkt logisch dat deze variabelen aan elkaar zijn gerelateerd. Toch blijken in de onderzoeken van Schouwenburg (1994) en Meerum Terwogt-Kouwenhoven (1990) dat aan planning en regelmaat gerelateerde variabelen in veel gevallen niet gekoppeld zijn aan persoons- en studiestijlvariabelen.

De voortgangstoets beoogt aan de ene kant dat kennis op een zodanige wijze wordt getoetst dat deze niet ten koste gaat van de overige studie-activiteiten (Van der Vleuten, Scherpbier, et al., 1996). Aan de andere kant richt de toets zich niet op het directe leereffect van het blokgebonden onderwijs, maar op de kennis die ook na afloop van de blokperioden is blijven hangen of anderszins is verworven. Barrows en Tamblyn (1980) argumenteren ten aanzien van 
kennis die bij probleemgestuurd onderwijs is verworven onder andere dat deze langer wordt onthouden. Het is dan ook de bedoeling dat het zwaartepunt van de vragen ligt op items die vragen naar lange termijn kennis (Van der Vleuten, Verwijnen \& Wijnen, 1996). De bloktoets daarentegen richt zich. wel op het leereffect van het blokgebonden onderwijs. Verschillen in toetsresultaten en studie-activiteiten staan centraal in de volgende vraagstelling.

5. Zijn regelmatig gespreide studie-activiteiten en probleemgestuurde studie-activiteiten als voorbereiding op de blok- en voortgangstoets van invloed op de scores cie op de betreffende toets worden behaald? Indien er sprake is van toetsen die aansluiten op het gewenste onderwijs zullen studenten het studiegedrag dat past binnen het onderwijs gehonoreerd zien. In dit geval betekent dit dat studenten met diep actief probleemgestuurd studiegedrag en regelmatige studieactiviteiten komen tot betere toetsresultaten. Sterker nog, studie-activiteiten welke specifiek gericht zijn op de toets in plaats van op de onderwijsgroep zouden geen effect mogen hebben op de toetsscore. Hierbij zal naar verwachting de aard van de voortgangstoets (zie ook vraagstelling 3 ) eerder aanleiding geven tot een positief effect van regelmatig gespreide studie-activiteiten dan de bloktoets. Temeer daar de voortgangstoets met name is gericht op het toetsen van kennis die zich ontwikkelt over langere termijn (Norman, 1991).

\section{Methode}

\section{Procedure}

Om de spreiding van studie-activiteiten te onderzoeken hebben studenten gedurende acht weken dagelijks bijgehouden hoeveel tijd zij besteedden aan hun studie. Deze periode betrof blok 1.4 van het studiejaar 1995-1996 en de eerste week van blok 1.5 . In de vakantieweek, welke viel tussen de vijfde en zesde week van het blok, zijn eveneens de studie-activiteiten bijgehouden. De tijdsbesteding is elke week van het onderzoek op een nieuw formulier bijgehouden en ingeleverd aan het eind van de betreffende week. Aan studenten werd ter voorkoming van vergeeteffecten en schattingsfouten nadrukkelijk verzocht het formulier dagelijks in te vullen.

In de eerste week van de vijfde blokperiode vond de tweede voortgangstoets van dat studiejaar plaats. De resultaten zullen worden gerelateerd aan deze 
voortgangstoets en aan de bloktoets van blok 1.4. In de vijlde week van de onderzoksperiode hebben studenten bovendien een schriftelijke vragenlijst omtrent probleemgestuurd studiegedrag ingevuld.

\section{Steekproeftrekking en populatie}

De respondenten betroffen een random steekproef van 80 van de in totaal 253 propedeuse studenten. Deze studenten hebben een schriftelijke vooraankondiging van het onderzoek toegezonden gekregen, waarna zij vervolgens telefonisch zijn gevraagd deel te nemen. in totaal zijn 72 studenten gestart met het onderzoek en uiteindelijk hebben 70 personen het gehele onderzoek afgerond (uiteindelijke respons $87.5 \%$ ). De acht niet gestarte studenten betroffen drie studenten die de studie bij aanvang van het onderzoek hadden afgebroken of tijdens het onderzoek gingen afbreken. Drie studenten waren telefonisch niet bereikbaar en reageerden vervolgens niet op het werzoek zelf contact op te nemen, éen student gaf aan niet deel te nemen vanwege persoonlijke problemen en ëén geselecteerde student bleek achteraf zowel schriftelijk als telefonisch niet bereikt. Aan het einde van het onderzoek ontvingen studenten een financiële vergoeding na het retourneren. van alle vragenlijsten.

\section{Materialen}

Registratie van studietijd aan zelfstudie en onderwijsactiviteiten

Voor de registratie van de studietijd zijn aparte formulieren ontworpen. Op het formulier is gevraagd naar afzonderlijke studieonderdelen uitgesplitst naar zelfstudie of het volgen van onderwijs. De studieonderdelen zijn onderverdeeld in onderwijsgroepsbijeenkomsten, colleges, statistiek onderwijs, twee trainingen en een practicum. Ten behoeve van het specifiek studeren voor de bloktoets en voortgangstoets zijn aparte categorieën gemaakt.

De variabelen 'totaal aantal studie-uren', "studie-uren die worden besteed aan gerichte bloktoets voorbereiding', 'studie-uren die worden besteed aan gerichte voortgangstoets voorbereiding' en 'regelmaat van spreiding wan studie-activiteiten over de blokperiode' uit de verzamelde data gegenereerd.

Voor het totaal aantal studie-uren is gebruik gemaakt het aantal uren dat tijdens blok 1.4 is besteed aan zelfstudie en het volgen van onderwijs. Dit bestaat uit de onderwijsgroeper, het statistiek onderwijs, de colleges, de 
trainingen en de practica, waarbij onderscheid is gemaakt tussen aental uren besteed aan het volgen van onderwijs en uren besteed aan zelfstudie. Het aantal uren dat specifiek is gestudeerd voor de blok-en voortgangstoets is de optelling van het aantal uren dat in totaal is besteed aan gericht studeren voor de betreffende toets. Als toelichting op bloktoets en voortgangstoets voorbereiding kregen studenten de volgende toelichting welke is weergegeven in figuur 4.1 .

Bloktoets / Voortgangstoets voorbereiding. Studeren anders dan voorbereiding op de ondenwijsgroepsbijeenkomsten, zoals het maken van oude toetsen, hemalen van bestudeerde teksten. Dit kan zowel individueel als met medestudenten.

Figuur 4.1 Toelichting bij definiëring van toetswoorbereiding

Het verschil in studietijd tussen de afzonderlijke weken van het blok geeft een indicatie voor hoe regelmatig studenten hun activiteiten spreiden. Voor de berekening van deze variabele wordt verwezen naar de analyse sectie.

\section{Probleemgestuurd studiegedrag}

Het probleemgestuurd studiegedrag van studenten is op dezelfde manier gemeten als in de studie beschreven in hoofdstuk 3. De vragenlijst naar probleemgestuurd studiegedrag bevat 24 vragen met situatiebeschrijvingen. Aan de vragenlijst liggen twee componenten van studiegedrag ten grondslag; 'aard' en 'activiteit'. Deze componenten kunnen gecombineerd leiden tot vier mogelijke typen studenten met probleemgestuurd studiegedrag; diep actief, diep passief, oppervlakkig actief en oppervlakkig passief. Elke situatiebeschrijving is karakteristiek voor éen van de vier typen probleemgestuurd studiegedrag gekoppeld aan ëen van de zes onderscheiden fases van het onderwijsleerproces. Studenten hebben de mate van herkenning over de voorgaande blokken gescoord op een viffpuntsschaal op elk wan de 24 situatieschetsen. Deze scores leiden tot een indeling in één van de vier typen en een intervalwaarde op de componenten aard en activiteit van probleemgestuurd studiegedrag. Voor de verdere beschrijving van het instrument wordt verwezen naar hoofdstuk 3 .

\section{Toetsresultaten}

De bloktoets van blok 1.4 bestaat uit een toets met 121 juist-onjuist vragen zonder vraagteken-optie. De bloktoetsscore betreft de procentuele goed-score 
die studenten op deze toets behaald hebben. De voortgangstoetsscore betreft de goed-min-fout score die is behaald op de tweede voortgangstoets van het studiejaar 1995-1996.

\section{Analyse}

De vraagstellingen omtrent regelmaat van studie-activiteiten, totale studietijd, probleemgestuurd studiegedrag en studietijd specifiek ter voorbereiding op toetsen worden beantwoord met beschrijvende statistiek en het berekenen van correlaties.

Regelmaat van studeren is bepaald door berekening van de standaarddeviatie over de gemiddelde studietijd per week. Hierin zijn opgenomen de tijd die is besteed aan zelfstudie voor de onderwijsonderdelen onderwijsgroep, statistiek en training gespreksvaardigheden. Deze onderdelen veronderstellen inhoudelijk een duidelijke relatie met de toetsen. De tijd die is besteed aan zelfstudie voor de bloktoets en voortgangstoets zijn als afzonderlijke variabelen behandeld en buiten beschouwing gelaten woor de berekening van regel. maat. Omdat de tijdsinvestering voor de training macro-economie en het practicum immunologie, die eveneens deel uitmaakten van de onderzochte blokperiode, met name in beslag werden genomen door het schrijven van verslagen zijn deze onderdelen buiten beschouwing gelaten.

Ter correctie van de invloed van de hoogte van het aantal studie-uren is de standaarddeviatie van een individuele student berekenend over zijn percentage studie-uren van de totale zelfstudietijd tijdens het blok (in plaats van op basis van de absolute aantallen). De vakantieweek is buiten beschouwing gelaten. Een grotere standaarddeviatie betekent minder regelmatige spreiding van studie-activiteiten. Ter vereenvoudiging van de interpretatie zijn voor de analyse deze standaarddeviaties gerangschikt van 1 tot 100 en omgecodeerd, waarmee de laagste waarde staat voor de student met de minst regelmatige spreiding van studie-activiteiten. Naast deze variabele is bovendien gebruik gemaakt van een indeling van studenten in drie groepen, de $33.3 \%$ studenten met de laagste waarden, de $33.3 \%$ met de middelste en de $33.3 \%$ met de hoogste waarden. Van deze driedeling wordt gebruik gemaakt om verschillen tussen de extremen in regelmaat van studie-activiteiten inzichtelijker te maken.

Verschillen tussen studenten met variatie in regelmaat van studie-activiteiten, studietijd, probleemgestuurd studiegedrag en toetsvoorbereiding worden 
zowel getoetst met behulp van een regressie analyse als een ANOVA, ondanks de overlap in de gehanteerde procedures. Met behulp van gelijktijdige toevoeging aan het regressiemodel wordt bekeken hoeveel procent van de variantie in toetsresultaten kan worden verklaard door de variabelen regelmaat van studie-activiteiten, studietijd, probleemgestuurd studiegedrag en. toetsvoorbereiding. Bovendien wordt de unieke toegevoegde waarde van de interval variabele regelmat van studeren onderzocht door de regressie analyse ook trapsgewijs uit te voeren waarbij de volgorde van toevoeging aan het regressiemodel is geforceerd en bif elke stap de (significantie van) de toegevoegde waarde wordt bepaald. Daarnaast wordt met behulp van een ANCOVA gelijktijdig de invloed van regelmaat van spreiding van studieactiviteiten en probleemgestuurd studiegedrag en hun onderlinge samenhang op toetsresultaten getoetst. Door de totale studietijd en het aantal uren specifieke toetswoorbereiding als co-variaten vooraf aan het model toe te voegen wordt de invloed van deze variabelen buiten beschouwing gelaten. Bij de ANCOVA wordt voor zowel regelmaat van studie-activiteiten als probleemgestuurd studiegedrag gebruik gemaakt wan de ordinale groepsindelingen.

\section{Resultaten}

\section{Representativiteit steekproef}

Voor de vergelijking van de zelfstudietijd van deelnemende en niet deelnemende studenten is gebruik gemaakt van de schattingen van de afgelopen vier blokperioden die studenten in het kader van programmamevaluatie hebben gegeven. In tabel 4.1 worden de bevindingen gerapporteerd.

De zelfstudietijd, bloktoetsscore en voortgangstoetsscore van de studenten die hebben deelgenomen aan het tijdschrijfonderzoek op geschatte zelfstudietijd en blok- en voortgangstoetsresultaten zijn vergelijkbaar met de overige eerstejaars studenten. Studenten die hebben deelgenomen aan het tijdschrijfonderzoek verschillen niet significant van de studenten die niet hebben deelgenomen op de geschatte zelfstudietijd gedurende de blokperioden 1.1 tot en met 1.4 en de toetsscores. 
Tabel 4.1 Gemiddelde zelfstudietijd (met standaarddeviatie tussen haakjes) op basis van programma-evaluatie en toetsresultaten tussen studenten die wel en niet hebben deelgenomen aan het tijdschrijfonderzoek

\begin{tabular}{|c|c|c|c|c|c|}
\hline \multirow{2}{*}{ zelfstudie: } & \multicolumn{2}{|c|}{ deelgenomen: } & \multicolumn{2}{|c|}{ niet deelgenomen } & \multirow[t]{2}{*}{ T-waarde } \\
\hline & & & & & \\
\hline blok 1.1 & 16. & (9.1) & 15.2 & $(7.5)$ & $-0.47 \mathrm{~ns}$ \\
\hline blok 1.2 & 16.1 & $(9.3)$ & 16.9 & $(8.4)$ & $0.58 \mathrm{~ns}$ \\
\hline blok 1.3 & 14.0 & (8.9) & 16.2 & (8.9) & $1.61 \mathrm{~ns}$ \\
\hline blok 1.4 & 15.1 & $(7.7)$ & 14.3 & (7.4) & $-0.73 \mathrm{~ns}$ \\
\hline bloktoetsscore (blok 1.4) & 72.5 & $(5.7)$ & 719 & $(5.7)$ & $-0.72 \mathrm{~ns}$ \\
\hline voortgangstoetsscore ( $\left(2^{\text {de }}\right.$ toets) & 43.4 & $(15.8)$ & 43.1 & $(15.2)$ & $-0.15 \mathrm{~ns}$ \\
\hline
\end{tabular}

ns $p>0.05$

\section{Betrouwbaarheid van de studietijd en typen probleemgestuurd studiegedrag}

De zelfstudie per week vertoont een hoge correlatie met de schatting van de zelfstudietijd per week van studenten welke in het kader van de programmaevaluatie is ingevuld aan het einde van de blokperiode $(r=0.67, p \leq 0.001$ ). De globale schatting uit de programma-evaluatie vragenlijst aan het einde van het blok ligt echter gemiddeld zeven uur hoger dan het gemiddeld aantal uren zelfstudie per week dat tijdens het tijdschrijfonderzoek is geregistreerd (15.1 ten opzichte van 8.1 uur) en is significant hoger (t $(55)=9.0, p \leq$ $0.001)$.

Op basis van het gemiddelde op de situatieschetsen die de typen probleemgestuurd studiegedrag representeren zijn studenten ingedeeld in één van de typen. Deze gemiddelden zijn weergegeven in tabel 4.2, met horizontaal tot welk type zij zijn ingedeeld en verticaal de gemiddelden op de situatieschetsen welke de typen representeren. Het vetgedrukte getal betreft het gemiddelde van het type probleemgestuurd studiegedrag waartoe zij zijn gerekend.

Tabel 4.2 Gemiddelde scores op de vragen die de verschillende typen probleemgestuurd studiegedrag gepresenteerd per typologie

\begin{tabular}{|c|c|c|c|c|c|}
\hline Typologie indeling: & $\begin{array}{l}\text { diep actief } \\
(n=23)\end{array}$ & $\begin{array}{l}\text { opp. actief } \\
(n=26)\end{array}$ & $\begin{array}{c}\text { diep passief } \\
(n=11)\end{array}$ & $\begin{array}{c}\text { opp. passief } \\
(n=7)\end{array}$ & $\begin{array}{l}\text { F -waarde } \\
D f=(3.63)\end{array}$ \\
\hline \multicolumn{6}{|l|}{ Germ. op vragen woor typalogie:" } \\
\hline diep actief & 3.3 & 2.4 & 1.7 & 1.4 & $426^{* * *}$ \\
\hline opperwakkig actief & 2.3 & 3.2 & 2.3 & 2.5 & $13.0 * * *$ \\
\hline diep passief & 2.4 & 2.2 & 3.0 & 2.4 & $15.6^{* * * 4}$ \\
\hline oppervlakkig passief & 1.7 & 2.0 & 2.5 & 3.2 & $20.6 * * *$ \\
\hline
\end{tabular}


Het grootste gedeelte van de studenten herkent zich in de beschrijvingen van oppervlakkig actief $(n=26)$ of diep actief studiegedrag $(n=23)$ en slechts weinig studenten zijn ingedeeld in de oppervlakkig passieve typologie $(n=7)$. Voor elk van de typologieën geldt dat de gemiddelde score op de typologie waarin men is ingedeeld significant hoger is dan de gemiddelde score op de andere drie typologieën.

\section{Spreiding van studie-activiteiten over de weken van de blokperiode}

In de regelmaat van spreiding van studie-activiteiten is onderscheid gemaakt tussen de tijd die studenten hebben besteed aan het deelnemen aan onderwijsactiviteiten en de tijd die ze hebben besteed aan zelfstudie (tabel 4.3).

Tabel 4.3 Gemiddeld aantal onderwijsuren en zelfstudie-uren over de weken van het blok

\begin{tabular}{lrrrrrrrr}
\hline & totaal & week 1 & week 2 & week 3 & week 4 & week 5 & vakantie & week 6 \\
\cline { 2 - 9 } onderwijstijd & 51.1 & 8.4 & 10.7 & 9.4 & 10.5 & 7.6 & 0.0 & 4.6 \\
zelfstudiettjd & 6.4 .2 & 7.0 & 9.4 & 8.9 & 8.3 & 6.4 & 4.8 & 19.3 \\
totaal & 115.2 & 15.4 & 20.1 & 18.3 & 18.8 & 14.0 & 4.8 & 23.9 \\
\hline verhouding & 1.3 & 0.8 & 0.9 & 1.0 & 0.8 & 0.8 & - & 4.2 \\
\hline
\end{tabular}

De tabel geeft de verdeling over de weken van het blok, met de onderlinge verhouding tussen zelfstudie-activiteiten en het deelnemen aan onderwijs. In totaal besteden studenten per week gemiddeld 14 tot 24 uren aan hun studie. Hiervan wordt ongeveer evenveel tijd besteed aan zelfstudie als aan het volgen van onderwijs. De verhouding tussen het aantal uren dat wordt gestudeerd en dat wordt besteed aan deelnemen aan onderwijs is hierbij betrekkelijk stabiel over de blokperiode, met uitzondering van de laatste week van het blok. In deze week is sprake van een betrekkelijk sterke toename van het aantal uren zelfstudie en een lichte daling van hei aantal onderwijsuren. De stijging is grotendeels toe te schrijven aan studeren voor de bloktoets. Bovendien blijkt er een duidelijke samenhang tussen de totale hoeveelheid studietijd en de regelmaat van de studie-activiteiten $(r=0.58, p \leq 0.001)$. Studenten die regelmatiger studeren besteden ook meer tijd aan hun studie. In figuur 4.1 worden verschillen tussen studenten in de verdeling van de studie-activiteiten over de weken van het blok weergeven op basis van de indeling in drie groepen ten aanzien van regelmaat van studie-activiteiten. 


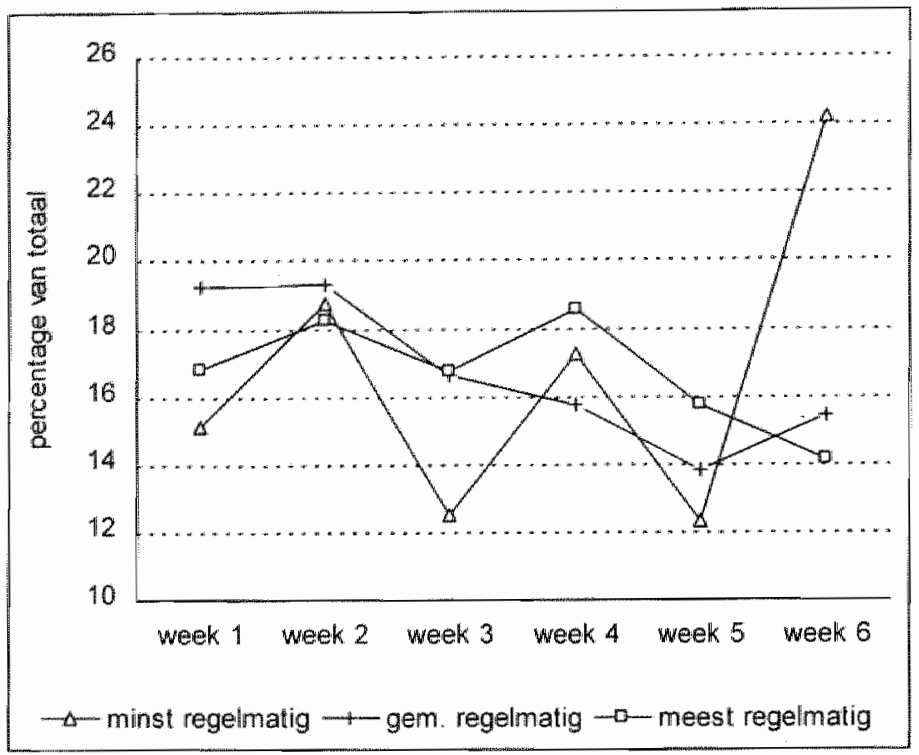

Figuur 4.2 Verdeling van de studietijd (procentueel ten opzichte van totaal) over de weken van het blok, uitgesplitst naar driedeling regelmaat van studiegedrag

Afwijkingen in de regelmaat van studie-activiteiten tussen de drie groepen worden met name veroorzaakt door de activiteiten in de laatste week van het blok. Bij de studenten die het meest regematig studeren treedt nauwelijks verandering op in hoeveelheid studietijd in de laatste week ten opzichte van de vorgaande weken, terwijl bij de twee andere groepen studenten sprake is van cen duidelijke toename in het aantal studie-uren.

\section{Regelmaat van studie-activiteiten en gerichte toetsvoorbereiding}

De correlatie tussen de regelmagt van spreiding van studie-activiteiten met het aantal uren toetsvoorbereiding is redelijk $(r=0.43, p \leq 0.001)$ voor de bloktoets en lager $(r=0.25, p \leq 0.05)$ voor de voortgangstoets. Studenten die hun studie-activiteiten regelmatig verspreid over een blokperiode verrichten besteden blikbaar meer tijd aan toetsvoorbereiding.

In tabel 4.4 is weergegeven hoeveel tijd studenten naast de reguliere studieactiviteiten hebben besteed aan gerichte toetsvoorbereiding voor de blok-en voortgangstoets. Hierbij is een onderverdeling gemaakt tussen de groepen studenten die het minst, gemiddeld en het meest regelmatig verspreid over het blok studeren. 
Tabel 4.4 Gemiddelde totaal aantal studie-uren en aantal uren toetsvoorbereiding voor de voortgangstoets en bloktoets, onderverdeeld naar regelmaat van studeren in drie groepen (met standaarddeviatie tussen haakjes)

\begin{tabular}{|c|c|c|c|c|c|c|c|c|c|}
\hline \multirow[b]{2}{*}{ totale studievijd } & \multicolumn{2}{|c|}{$\begin{array}{c}\text { totaal } \\
(n=70)\end{array}$} & \multicolumn{2}{|c|}{$\begin{array}{l}\text { minst regeimatig } \\
\qquad(n=23)\end{array}$} & \multicolumn{2}{|c|}{$\begin{array}{l}\text { gem regelmatig } \\
\qquad(n=24)\end{array}$} & \multicolumn{2}{|c|}{$\begin{array}{l}\text { mest regelmatig } \\
\qquad(n=23)\end{array}$} & \multirow{2}{*}{$\frac{\text { F-waande }}{17.3}$} \\
\hline & 115.2 & $(36.2)$ & 90.8 & $(22.6)$ & 1126 & $(22.4)$ & 142.4 & $(41.0)$ & \\
\hline studietijd BT & 15.1 & $(10.6)$ & 9.9 & $(4.9)$ & 45.0 & $(8.4)$ & 20.6 & $(14.0)$ & $6.8 *$ \\
\hline studiefijd VGT & 11.8 & $(2.9)$ & 0.9 & $(1.2)$ & 1.8 & $(2.1)$ & 2.5 & $(4.4)$ & $4.8 \mathrm{~ns}$ \\
\hline
\end{tabular}

ns $p>0.05 ;{ }^{*} p \leq 0.01 ;{ }^{* * *} p \leq 0.001$

Er wordt door studenten op betrekkelijk grote schaal gericht gestudeerd voor de bloktoets (gem. 15 uur). Aan gericht studeren voor de voortgangstoets wordt gemiddeld minder dan twee uur besteed. Studenten met de meest regelmatige studie-activiteiten besteden naast het hoogste aantal studieuren, bovendien de hoogste voorbereidingstijd voor de blok- en de voortgangstoets. De verschillen zijn significant op de totale studietijd en de voorbereidingstijd voor de bloktoets.

\section{Regelmaat van spreiding van studie-activiteiten, probleemgestuurd studiege- drag en toetsresultaten}

De onderlinge samenhang tussen regelmaat van spreiding van studie-activiteiten, de studietijd variabelen en aard en activiteit van probleemgestuurd studiegedrag met studieresultaten zijn weergegeven in tabel 4.5 .

Tabel 4.5 Correlatie matrix voor de variabelen toetsvoorbereiding, probleemgestuurd studiegedrag, blok-(BT) en voortgangstoetsscore (VGT) $(n=70)$

\begin{tabular}{llllllll}
\hline & $\begin{array}{l}\text { VGT } \\
\text { score }\end{array}$ & $\begin{array}{l}\text { BT } \\
\text { score }\end{array}$ & activiteit & aard & tegelmatat & $\begin{array}{l}\text { totale } \\
\text { studietijd }\end{array}$ & $\begin{array}{l}\text { uren stu- } \\
\text { deren BT }\end{array}$ \\
\cline { 2 - 8 } BT score & $0.43^{* * *}$ & & & & & & \\
PGO activiteit & 0.14 & -0.10 & & & & & \\
PGO aard & 0.18 & 0.10 & $0.41^{* * *}$ & & & & \\
regelmaat & 0.16 & 0.23 & -0.17 & -0.18 & & & \\
totale studietijd & 0.24 & $0.33^{* *}$ & -0.06 & -0.12 & $0.62^{* * * *}$ & & \\
uren studeren BT & $0.04^{*}$ & $0.13^{*}$ & 0.11 & -0.10 & $0.43^{* * *}$ & $0.79^{* * *}$ & \\
uren studeren VGT & $0.25^{*}$ & $0.30^{*}$ & 0.09 & -0.14 & $0.25^{*}$ & $0.47^{* * *}$ & $0.37^{* *}$ \\
\hline
\end{tabular}

* $p \leq 0.05^{* * *} p \leq 0.01 ; * * * w p \leq 0.001$

De regelmaat van studie-activiteiten vertoont weinig relatie met de aard ( $\mathrm{r}=$ $0.18)$ en activiteit $(r=-0.17)$ van probleemgestuurd studiegedrag. Het aantal 
uren dat voor de blok- respectievelijk de voortgangstoets wordt gestudeerd vertoont een positieve significante correlatie met het totaal aantal studieuren $(r=0.79$ respectievelijk $r=0.50)$. De regelmaat van studeren hangt sterk samen met het aantal studie-uren tijdens het blok en voor de bloktoets $(r=0.62$ en $r=0.43)$ en vertoont iets minder samenhang, maar niettemin significant, met het aantal studie-uren voor de voortgangstoets $(r=0.25)$. De regelmaat van studeren vertoont, gegeven de invloed van de overige variabelen, enige samenhang met de scores op de toetsen, respectievelijk $r=0.16$ met de voortgangstoets en $r=0.23$ met de bloktoets.

Evenals in hoofdstuk 3 vertonen de variabelen aard en activiteit van het studiegedrag een betrekkelijk hoge samenhang $(r=0.41)$ en zullen daarom als een gezamenlijk construct voor probleemgestuurd studiegedrag worden beschouwd. Deze variabelen vertonen een (laag) positieve niet significante correlatie met de toetsscores, met uitzondering van een negatieve correlatie tussen 'activiteit' van het probleemgestuurd studiegedrag met de bloktoetsresultaten.

Met behulp van een regressie-analyse is de gezamenlijke invloed van de regelmaat van het studiegedrag tijclens het blok, de wijze van toetsvoorbereiding en probleemgestuurd studiegedrag op de toetsscores onderzocht. Bij deze analyses zijn de intervalwaarden op de dimensies aard en activiteit van probleemgestuurd studiegedrag, gelijktijdig toegevoegd aan de vergelijking, gebruikt.

In tabel 4.6 worden de regressie-gewichten van de variabelen ter verklaring van de voortgangstoetsscore weergegeven.

Tabel 4.6 Regressie-gewichten ter verklaring van de voortgangstoetsscore; studie-uren, regelmaat van studeren en probleemgestuurd studiegedrag

\begin{tabular}{lcccc}
\hline & $\mathrm{B}$ & seB & $\beta$ & $\mathrm{T}$ \\
\cline { 2 - 5 } votáal aantal studie-uren & 0.06 & 0.07 & 0.13 & $0.77 \mathrm{~ns}$ \\
studie-uren voor voortgangstoets & 1.03 & 0.73 & 0.19 & $1.41 \mathrm{~ns}$ \\
activiteit PGO studiegedrag & 0.47 & 1.15 & 0.05 & $0.41 \mathrm{~ns}$ \\
aard van PGO studiegedrag & 2.82 & 1.75 & 0.22 & $1.62 \mathrm{~ns}$ \\
regeimaat van zelfstudie & 0.07 & 0.12 & 0.09 & $0.58 \mathrm{~ns}$ \\
(Constant) & 32.19 & 6.85 & & $4.70^{* * *}$ \\
\hline
\end{tabular}

nsp $>0.05 x^{* * * t} p>0.001$ 
In totaal wordt slechts $13.9 \%$ van de hoogte op de voortgangstoets werklaard door de variabelen regelmaat van het studiegedrag tijdens het blok, de wijze van toetsvoorbereiding en probleemgestuurd studiegedrag. Geen van de variabelen levert een significante bijdrage, gegeven de hoogte van de andere variabelen. De bijdrage van probleemgestuurd studiegedrag en regelmaat van studeren is apart nagegaan. Als eerste is het aandeel van de variabelen totaal aantal studie-uren en studie-uren voor de toets bepaald (verklaarde variantie $=8.0 \%$, waaraan vervolgens in de tweede stap aard en activiteit van het probleemgestuurd studiegedrag zijn toegevoegd. Deze toevoeging van probleemgestuurd studiegedrag leidt tot een verklaarde variantie van $13.4 \%$ $(\mathrm{F}(63,4,2,2)=2.091, \mathrm{p}>0.05)$. In de derde stap is regelmat van studeren toegevoegd, waarmee de verklaarde variantie komt op $13.9 \%$. Deze toevoeging levert eveneens geen significante verbetering op $(F(62,5,1,4)=0.335$, $p>0.05 i$.

De regressie-gewichten van de variabelen toetsvoorbereiding, probleemgestuurd studiegedrag en regelmat van studeren ter verklaring van do bloktoetsscore worden weergegeven in tabel 4.7.

Tabel 4.7 Regressie-gewichten ter verklaring van de bloktoetsscore; studie-uren. regelmaat van studeren en probleemgestuurd studiegedrag

\begin{tabular}{|c|c|c|c|c|}
\hline & B & $\operatorname{seB}$ & $\beta$ & $T$ \\
\hline totaal aantal studie-uren & 0.09 & 0.04 & 0.54 & $2.41^{*}$ \\
\hline studie-uren woor bloktoets & -0.29 & 0.43 & -0.09 & $-0.68 \mathrm{~ns}$ \\
\hline activiteit PGO studiegedrag & 0.89 & 0.62 & 0.18 & $1.41 \mathrm{~ns}$ \\
\hline aard van PGO studiegedrag & 0.01 & 0.04 & 0.03 & $0,18 \mathrm{~ns}$ \\
\hline regelmaat van zelfstudie & -0.14 & 0.11 & -0.27 & $-1.37 \mathrm{~ns}$ \\
\hline (Constant) & 64.61 & 2.72 & & $23.79 * * *$ \\
\hline
\end{tabular}

In totaal wordt $17.6 \%$ van de hoogte op de bloktoets verklaard door de variabelen regelmaat van het studiegedrag tijdens het blok, de wijze van toetsvoorbereiding en probleemgestuurd studiegedrag. Alleen de variabele 'aantal studie-uren tijdens het blok" levert een significante bijdrage, gegeven de waarde op de andere variabelen.

De gezamenlijk toegevoegde bijdrage van de variabelen aard en activiteit van het probleemgestuurd studiegedrag geeft een verklaarde variantie van 17.6 $\%$, welke geen significante verbetering oplevert $(\mathrm{F}(61,4,2,2)=0.993, \mathrm{p}>$ 0.05 ) ten opzichte van de verklaarde variantie wan $14.9 \%$ door de variabelen 
toetsvoorbereiding (totaal aantal studie-uren en studie-uren voor de bloktoets). De unieke toegevoegde bijdrage van spreiding van studie-activiteiten aan deze vier variabelen is eveneens niet significant $(F(60,5,1,4)=0.031, \mathbb{p}$ $>0.05)$ met een toename in verklaarde variantie die slechts zichtbaar bij weergave met drie decimalen nauwkeurig (van $17.585 \%$ naar $17.627 \%$ ). De resultaten van gelijktijdige toetsing (ANCOVA) van verschillen in toetsresultaten voor de vier types probleemgestuurd studiegedrag en de drie groepen minst: regelmatig, gemiddeld regelmatig en regelmatigst studerend zijn weergegeven in tabel 4.8. De co-variaten zijn eerst toegevoegd. Hierdoor is vooraf gecorrigeerd voor verschillen in studietijd tijdens het blok en voor de betreffende taets.

Er is geen significant verschil in de bloktoetsscore tussen de types probleemgestuurd studiegedrag en types mate van regelmaat van studeren. Tevens is er geen interactie-effect tussen probleemgestuurd studiegedrag en regelmat.

Tabel 4.8 Effect van regelmaat van studeren en type probleemgestuurd studiegedrag op blok- en voortgangstoetsscore, na correctie voor studietijd

\begin{tabular}{|c|c|c|c|c|c|c|}
\hline & \multicolumn{3}{|c|}{ Bloktoetsscore } & \multicolumn{3}{|c|}{ Voortgangstoetsscore } \\
\hline & $S S(d f)$ & MS & F-waarde & SS (df) & MS & F-waarde \\
\hline Co-variaten & $269.422(2)$ & 134.711 & $4.892 *$ & $1672.217(2)$ & 835.109 & $3.848^{*}$ \\
\hline - studie-uren BT | VGT & $28.020(1)$ & 28.020 & $1.018 \mathrm{~ns}$ & $1332.352(1)$ & $\$ 332.352$ & $6.291 *$ \\
\hline - studie-uren tijdens blok & $241.402(1)$ & 241.402 & $8.767 * *$ & $339.865(1)$ & 339.865 & $1.605 \mathrm{~ns}$ \\
\hline Hoofd effect & $104354(5)$ & 0.871 & $0.758 \mathrm{~ns}$ & $2903.003(5)$ & 580.601 & $2.741^{*}$ \\
\hline - type PGO gedrag & $61.332(3)$ & 0.444 & $0.742 \mathrm{~ns}$ & $2860.619(3)$ & 953.540 & 4.502 ** \\
\hline - type regelmaat & $43.022(2)$ & 21.511 & $0.781 \mathrm{~ns}$ & $42.383(2)$ & 21.192 & $0.100 \mathrm{~ns}$ \\
\hline \multicolumn{7}{|l|}{ Interactie effect } \\
\hline - type PGO-regelmaat & $134.579(6)$ & 22.430 & $0.815 \mathrm{~ns}$ & $144,292(6)$ & 190.715 & $0.9100 \mathrm{~ns}$ \\
\hline Verklaard & $508.355(13)$ & 39.104 & $1.420 \mathrm{~ns}$ & $5719.512(13)$ & 439.962 & $2.077 *$ \\
\hline Residu & $1349.183(49)$ & 27.534 & & $10801.473(51)$ & 211.794 & \\
\hline Totaal & $1857.538(62)$ & 29.960 & & $16520.985(64)$ & 258.140 & \\
\hline
\end{tabular}

ns $p>0.05 ; " p \leq 0.05_{*}^{* * *} p \leq 0.01$

Na verwijdering van het effect van de co-variaten op de voortgangstoetsscore blijkt een significant effect voor het type probleemgestuurd studiegedrag en geen effect voor regelmaat van studeren. Het type probleemgestuurd studiegedrag blijkt verschil uit te maken in de verklaring van voortgangstoetsscores terwijl dit niet het geval is voor de variabele regelmaat. Er is, evenals bij de bloktoets, geen interactie elfect tussen type probleemgestuurd studiegedrag en regelmaat. 


\section{Discussie en conclusie}

In de beschreven studie is onderzoek gedaan naar de verdeling van studieactiviteiten rond het onderwijs binnen een blokperiode en de mate waarin regelmaat van activiteiten is gerelateerd aan toetsresultaten. De gegevens in deze studie zijn verzameld met behulp van een tijdschrijfonderzoek over een periode van acht weken.

Vanwege lage respons en selectieve deelname ten aanzien van betere studenten en/of grotere studie-inspanning wordt de mogelijkheid om met tijdschrijfonderzoeken betrouwbare gegevens te verkrijgen nogal eens ter discussie gesteld (Crombag \& Vos, 1982; Van Gelderen \& Ten Cate, 1985). In tegenstelling tot eerder tijdschrijfonderzoek is de respons in het hier beschreven onderzoek hoog (finale respons $87.5 \%$ ) en de uitval laag (slechts twee studentej. Ook geeft vergelijking van de geselecteerde studenten met niet geselecteerde studenten op toetsresultaten en programma-evaluatie gegevens van (retrospectief) geschatte zelfstudietijd geen aanleiding tot de veronderstelling van selectieve deelname. Kennelijk is de aanbeveling van Crombag en Vos (1982) juist dat het verkleinen van de non-respons met een persoonlijke benadering en forse tijdsinvestering loont. $\mathrm{E} r$ is een goed verband tussen de globale schatting van studie-uren en de tijdschrijf-resultaten, maar de globale methode leidt gemiddeld wel tot een forse overschatting.

Spreiding van studie-activiteiten. Op basis van de beschreven studie kan geconcludeerd worden dat de propedeuse studenten betrekkelijk regelmatig gespreid over een blokperiode studeren. Studenten besteden hierbij ongeveer even veel tijd aan onderwijsdeelname als aan zelfstudie. Alleen in de laatste week van het blok wordt duidelijk meer tijd besteed aan de zelfstudie dan aan onderwijsdeelname. Dit is in tegenstelling met de bevindingen van bijvoorbeeld Van der Drift en Vos (1987) en Cohen-Schotanus (1991) die sterk onregelmatige studie-activiteiten vinden, met een stijging van het aantal studie-uren vlak voor een toets. Hun bevindingen zijn echter gebaseerd op traditionele curricula.

Ook bij het probleemgestuurd onderwijs in de hier beschreven studie, is sprake van een verdubbeling van het aantal studie-uren in de laatste week voor de toets. Probleemgestuurd onderwijs lijkt in dit opzicht toch bij veel studenten aan te sturen tot aaneengeschakelde voorbereiding van de onderwijsgroepen (Van der Vleuten, Scherpbier, et al., 1996). Dit neemt niet weg 
dat het automatisme waarmee studenten hun kennis hierdoor zouden zien stijgen, helemaal het geval blijkt. Naast de aaneengeschakelde voorbereiding voelen studenten zich ook genoodzaakt om zich specifiek op toetsen voor te bereiden en wordt in de dagen voorafgaande aan de toetsen in bepaalde mate specifiek voor de toetsen geleerd. Dit verschijnsel treedt in sterkere mate op bij de bloktoets (gemiddeld 15 uur) met zijn afgebakende kennisdomein dan bij de voortgangstoets (gemiddeld nog geen twee uur) met het brede curriculum onafhankelijke kennisdomein. Dit bevestigt de veronderstelling dat het ontbreken van de directe koppeling tussen de inhoud van de toets en de inhoud van het onderwijs bijdraagt aan het voorkomen van een sturende werking van de voortgangstoets (Van der Vleuten, Verwijnen \& Wijnen, 1996). Hierbij dient opgemerkt te worden dat dit onderzoek plaats vond binnen de propedeuse Gezondheidswetenschappen en binnen één blokperiom de. De keuze voor de vijfde blokperiode was een bewuste keuze, waarbij is verondersteld dat dit blok qua inlhoud niet zeer specifiek is, en daarmee redelijk exemplarisch voor de studie. Conclusies over hoe regelmatig er wordt gestudeerd binnen Gezondheidswetenschappen, of nog breder binnen probleemgestuurd onderwijs, moeten daarom met voorzichtigheid worden bezien.

Regelmaat en toetsvoorbereiding. De aan het begin van dit hoofdstuk geformuleerde veronderstelling dat studenten met regelmatiger studie-activiteiten zich minder genoodzaakt voelen tot specifiek voor de toetsen studeren blijkt niet juist. De theoretische uiteenzetting van Schouwenburg (1994) over het verschijnsel uitstelgedrag geldt kennelijk niet voor de probleemgestuurde onderwijssetting van dit onderzoek. Het tegengestelde blijkt namelijk het geval: studenten met regelmatiger studie-activiteiten besteden daar bovenop meer tijd aan de studie èn aan het specifiek studeren voor de hier onderzochte toetsen. Wellicht maakt de vormgeving van het onderwijs dat studie-activiteitem, in de vorm van het voorbereiden van onderwijsgroepen, niet worden uitgesteld tot het lange termijn doel 'toetsen halen' dichter bij komt, maax worden met de onderwijsgroepen telkens korte termijn doelen geboden. Vervolgens wordt bij het naderen van de toetsen ook het -dan korte termijn-doel 'toetsen halen' sturend.

Regelmaat en studiegedrag. Eveneens niet in overeenstemming met de aan het begin van dit hoofdstuk geformuleerde verwachting blikt de regelmaat van onderwijsactiviteiten nauwelijks gerelateerd aan probleemgestuurd 
studiegedrag. Het blijkt niet zo dat de wenselijke aaneengeschakelde studieactiviteiten in voorbereiding op de onderwijsgroep ook vanzelfsprekend worden voortgezet in of omgezet in volgens probleemgestuurd onderwijs wenselijk gedrag of activiteiten in de onderwijsgroep. De inzet, discipline of motivatie om met regelmaat te studeren voor de onderwijsgroep staat kennelijk los van het studiegedrag dat in de onderwijsgroep wordt verondersteld als actief vragen stellen, rapporteren en uitleggen of kritisch verbanden zoeken, relateren en naar inzicht in de nieuwe informatie zoeken.

Regelmaat, studiegedrag en toetsvoorbereiding. De variabelen studietijd (totaal en specifiek voor de toets), regelmaat van studie-activiteiten en probleerngestuurd studiegedrag (aard en activiteit) omtrent studie-activiteiten en studiegedrag blijken in staat $18 \%$ van de variantie in bloktoetsresultaten en $14 \%$ van de variantie in voortgangstoetsresultaten te verklaren. Evenals in de studie naar probleemgestuurd studiegedrag (Van Til, Van der Vleuten \& Van Berkel, 1997a; zie ook hoofdstuk 3) blijkt probleemgestuurd studiegedrag een significante verbetering in de verklaarde variantie van de voortgangstoetsresultaten. Een direct effect van regelmatiger studeren blijkt niet zichtbaar te worden in betere voortgangstoetsresultaten. Dit lijkt enigszins in strijd met de bevindingen uit de studie van Gaynor en Millham (1976). In hun studie blijkt binnen een cursus voor studenten die regelmatig worden getoetst een beter leereffect in vergelijking tot studenten die alleen een eindtoets hebben. Dit hogere leereffect wordt mogelijk veroorzaakt door de regelmaat waartoe studenten worden geactiveerd met het toetsschema. Het ontbreken van een effect van regelmaat wordt in de studie van dit hoofdstuk getrokken binnen een curriculum waarin de studie-activiteiten van studenten wellicht betrekkelijk sterk gereguleerd worden door de regelmatige stimulans van de onderwijsgroepsbijeenkomsten. De spreiding tussen studenten qua regelmaat is hierdoor beperkt en zou de invloed van regelmaat indirect verondersteld kunnen worden via de (betrekkelijk regelmatige) activiteiten voor de onderwijsgroep.

Het op het eerste gezicht lage percentage is wellicht relatief redelijk te noemen tegen de achtergrond van het onderzoek van Meerum Terwogt-Kouwenhoven (1990) waarin slechts $45 \%$ van de variantie in studieresultaten kan worden verklaard met een veel groter aantal variabelen over studie-activiteiten. 
De hogere verklaarde variantie in bloktoetsresultaten met de vijf gebruikte variabelen ten opzichte van de voortgangstoetsresultaten wordt wooral beinvloed door het aantal studie-uren. Deze verschillen kunnen niet worden toegeschreven aan de gehanteerde vraagvorm omdat voor beide gebruik is gemaakt van de juist-onjuist vraag. Dit indiceert in de eerste plaats dat de voortgangstoets duidelijk andere kennis toetst dan de bloktoets. Bij het studeren voor een afgebakend kennisdomein is het waarschijnlijker dat met een extra inspanning (al of niet op het laatste moment) een en ander kan worden gecompenseerd. Bij het breed te toetsen kennisdomein van de voortgangstoets daarentegen lijkt het onmogelijk in korte tijd alle leerstof te herhalen. Dat de voortgangstoets 'beklijwende' kennis meet wordt versterkt met opnieuw de bevinding dat de wijze van omgaan met en de activiteiten in het kader van probleemgestuurd onderwijs wel een significante bijdrage aan de verklaring van de hoogte van de toetsscore leveren, terwijl dit bij de bloktoets niet het geval is (zie ook hoofdstuk 3). Bovendien leveren de tijd en spreiding variabelen geen significante bijdrage.

Geconcludeerd kan worden dat binnen probleemgestuurd onderwijs studenten niet alleen door de afname van toetsen, maar juist ook door de programmering van onderwijsgroepen, worden gestimuleerd tot studie-activiteiten. Beide hebben hun invloed op de spreiding van activiteiten. Hierbij blijkt dat de bloktoets een sterkere verstoring oplevert voor het regelmatig spreiden van studie-activiteiten, ten koste van studie-activiteiten voor de onderwijsgroep, dan de voortgangstoets. Een betere spreiding van studie-activiteiten komt niet direct tot uiting in betere studieresultaten. Daarentegen hebben probleemgestuurde studie-activiteiten opnieuw wel een positieve invloed op de studieresultaten. Dit effect is sterker zichtbaar bij de voortgangstoets dan bij de bloktoets. Waarmee dit een aanwijzing vormt dat met de voortgangstoets in vergelijking tot de bloktoets een ander soort kennis wordt gemeten, of in elk geval dat daarin andere studie-activiteiten tot uitdrukking komen. De bevindingen in dit onderzoek versterken de veronderstelling dat sturende werking van de voortgangstoets marginaal is en daarmee de verstoring ten koste van studie-activiteiten voor de onderwijsgroep is slechts van beperkte omvang. 


\section{Sturend effect van de voortgangstoets: een inventarisatie van de sturing tot specifieke studie-activiteiten}

In dit vijfde hoofdstuk wordt een studie beschreven waarin nader is onderzocht welke sturing de voortgangstoets geeft aan het studiegedrag van studenten. Welke studie-activiteiten ondernemen zij voor de voortgangstoets en hoeveel tijd besteden zij hieraan. Tevens is nagegaan welke opvattingen er bestaan onder studenten die niet voor de voortgangstoets studeren: redenen waarom zij niet studeren en hun verwachtingen over effecten van verschillende studie-activite:ten ter voorbereiding op de voortgangstoets. De resultaten van de hier gepresenteerde studie zijn gebaseerd op een vragenlijst welke is voorgelegd aan alle studenten Gezondheidswetenschappen na afloop van de tweede voortgangstoets van studiejaar 1996-1997.

\section{Inleiding en probleemstelling}

De studie-activiteiten van studenten worden in sterke mate beïnvloed door toetsing. Studenten reageren met hun studie-activiteiten op datgene wat wordt getoetst. Toetsing vormt dan ook een krachtig instrument om te sturen wat studenten (gaan) bestuderen en op welke manier iets wordt bestudeerd. Verwachtingen van studenten over de toetsinhoud hebben tot gevolg dat studenten meer tijd gaan besteden aan datgene wat wordt getoetst, ten koste van hetgeen niet wordt getoetst (Frederiksen, 1984).

Met de ontwikkeling van de voortgangstoets werd gezocht naar een toetsvorm welke geen invioed heeft op het studiegedrag van studenten. Kenmerken die hieraan zouden bijdragen zijn dat de toetsafnames plaatsvinden onafhankelijk van welk onderwijs (inmiddels) is gevolgd of vordering in de studie, de inhoud van het getoetste kennisdomein is zodanig breed dat studenten niet weten waar ze moeten beginnen en de toetsitems vragen niet naar kleine 
feiten maar kennis die ontstaat en opgebouwd wordt over een langere periode (Van der Vleuten, Verwijnen \& Wijnen, 1996).

Toch lijkt het er op dat er in de loop der jaren een verandering is opgetreden. De introductie van de toekenning van studiepunten aan de voortgangstoets heeft er bij de Faculteit der Geneeskunde toe geleid dat studenten zich in steeds grotere getale gaan voorbereiden op de voortgangstoets.

Ook bij de Faculteit der Gezondheidswetenschappen doet het verschijnsel zich voor dat een aantal studenten zich voorbereiden op de toets Van Til et al., 1996; Van Til, Van der Vleuten \& Van Berkel, 1997b, zie ook hoofdstuk 3 $\&$ 4). In de studie naar regelmaat van studieactiviteiten (zie hoofdstuk 4) bleken slechts 12 van de 70 eerstejaars studenten $(17 \%)$ de vraag waaruit bestaat je voorbereiding op de voortgangstoets' te beantwoorden met 'niets' (inclusief zorgen dat ik bij de toets goed uitgeslapen ben).

Gelet op de opzet van de voortgangstoets bij de Faculteit der Gezondheidswetenschappen kunnen de waarden zoals deze zijn gevonden in het eerste studiejaar in bepaalde mate afwijken van de overige studiejaren. Toch lijkt éen van de veronderstelde kenmerken van de voortgangstoets in het geding. Om na te gaan op welke schaal toetsgericht wordt gestudeerd en daarmee welke sturing op studie-activiteiten de voortgangstoets heeft, is deze studie opgezet. De centrale probleemstelling luidt: "in welke mate worden de studieactiviteiten van studenten gestuurd door de voortgangstoets en in hoeverre zijn deze (eventuele) activiteiten gerelateerd aan de prestaties op de voortgangstoets?"

\section{Achtergrond sturing van studie-activiteiten door toetsing}

In diverse studies werden aspecten van toetsing gevonden die invloed hebben op de studie-activiteiten en het studiegedrag van studenten. Het feit dat studenten iets gaan besturen vanwege het feit dat er wordt getoetst bleek in een experiment van Halpin en Halpin (1982). In hun onderzoek werd gevonden dat studenten die weten dat na afloop van de cursus zal worden getoetst meer inzet tonen en meer tijd besteden aan de studie in vergelijking met studenten die studeren om te leren. De auteurs vonden bovendien een interactie-effect tussen de twee studeercondities (leren voor de toets of studeren om te leren) en drie toetscondities (multiple choice toets, toets met korte antwoorden en geen toets), wat er volgens de auteurs op wijst dat er ook een 
leereffect optreedt van het toetsen op zich zelf. Bij afname van een retentietest na zes weken was dit effect nog steeds aanwezig.

Het experiment van Ellis, Wulfeck en Montague (1980) laat bovendien zien dat studenten datgene wat zij gaan bestuderen aanpassen aan wat zij verwachten dat wordt getoetst, en het daarmee waarschijnlijk vooral bestuderen omdat het wordt getoetst. Hun experiment bestond uit zeven achtereenvolgende toetsmomenten met verschillende condities. In deze condities varieerde de aansluiting van het onderwijsmateriaal op de toetsinhoud. In de ver schillende condities werd gevarieerd met het aantal oefenvragen dat werd aangeboden in het onderwijsmateriaal en die vervolgens terug kwamen in de toets $(100 \%, 50 \%$ en $0 \%)$. De onderzoekers zagen na de eerste toetsafname een aanpassing van de studie-activiteiten van de studenten. Bij een afnemende overlap tussen de oefenvragen en de toetsvragen werd niet alleen een negatieve correlatie met prestaties, maar ook met studietijd waargenomen. De auteurs concluderen dat zowel de onderwerpen die worden bestudeerd als de tijd die am onderwerpen wordt besteed wordt beinvloed door de verwachting of deze stof in de toets terug zal komen.

Naast aanpassing aan de (verwachte) inhoud van de toets wordt vaak gesuggereerd dat studenten hun studie-activiteiten ook afstemmen op de toetsvorm waarmee ze zullen worden getoetst. Hakstian (1971) benoemt in de inleiding van zijn studies de tot dan toe tegenstrijdige bevindingen hierover. In de door hem verrichte interventie-studies verschillen studenten niet in voorbereidingstyd, wijze van orgamiseren van het studiemateriaal en wijze van bestuderen van het materiaal, onder drie condities omtrent de verwachte toetsvorm; gesloten vragen, open vragen of een combinatie vam beide. Variatie in de toetsvorm waarop studenten zich voorbereidden resulteerden niet in verschillen op toetsresultaten op zowel een toets met open vragen als een toets met gesloten vragen. Ook op een retentiemeting na twee weken worden geen verschillen gevonden.

In een vragenlijst-studie gehouden onder eerstejaars studenten rapporteert $56 \%$ hun studie-activiteiten aan te passen aan de toetsvorm (Yang, Verheul, Verhelst \& Van Essen, 1985). Studie-activiteiten die het duidelijkst door toetsverwachting worden beinvloed zijn 'hardop samenvatten', 'maken van samenvattingen', 'zoveel mogelijk uit het hoofd leren' en hoofdpunten formuleren'. Zowel in de voorbereiding van multiple choice vragen als open vragen richt de voorbereiding zich op het organiseren en structureren van de stof. 


\section{Hoofdstuk 5}

Bij de voorbereiding van open vragen neemt dit soort activiteiten een iets belangrijkere plaats in, alleen likt het erop dat in de voorbereiding op open wragen de activiteiten 'hardop samenvatten', "maken van samenvattingen", 'zoveel mogelijk wit het hoofd leren' en 'hoofdpunten formuleren' daar bovenop worden gedaan.

Het belang van een goede afstemming tussen de doelstellingen van het onderwijs en de inrichting van het toetssysteem in zijn totaliteit illustreert de beschrijving van een gewijzigde toetssituatie in de studie van Newble en Jeager (1983). De invoering van een nieuw klinisch examen, met een theoretisch gedeelte, leidde tot een herstel van evenredige aandacht in studieactiviteiten van studenten voor het theoretisch gedeelte van de toets ten opzichte van het klinische gedeelte. Voor invoering van het nieuwe examen stond de invioed van het theoretisch gedeelle van het examen op de studieactiviteiten van studenten in geen enkele verhouding tot het belang hiervan voor het toekomstig beroep, terwijl het onderwijs met name was gericht op praktische voorbereiding op de beroepsuitoefening. In een evaluatie na acht jaar bleek van het 'nieuwe' examen een blijvend positief effect uit te gaan op de studie-activiteiten van studenten (Newble, 1988).

Toetsing heeft bovendien het gevolg dat de studie-activiteiten van studenten tijdelijk grotendeels zijn gericht op het studeren voor de betreffende toets ten koste van de overige studie-activiteiten (Cohen-Schotanus, 1994). Ook bij probleemgestuurd onderwijs treedt dit verschijnsel op, zij het in beperktere omvang. In de eerder verrichte studie naar regelmaat van studie-activiteiten werd in de laatste week voor de bloktoets bij een gedeelte van de studenten een daling in studie-uren voor de onderwijsgroepsbijeenkomsten waargenomen tegenover een behoorlijk aantal uren specifiek studeren voor de bloktoets (zie hoofdstuk 4). Dit verschijnsel trad bij de afname van de voortgangstoets sllechts in beperkte omwang op.

Bovenstaande studies illustreren dat bij de constructie van een toets niet alleen de afweging welke toetsvorm gebruikt gaat worden van belang is, maar juist de vraag moet worden gesteld welke kennis (en vaardigheden) studenten met de opleiding zouden moeten ontwikkelen. Deze kennis (en vaardigheden) moeten vervolgens worden getoetst. Studenten vertonen strategisch gedrag, zij studeren omdat wordt getoetst, bestuderen de onderwerpen welke zij verwachten in de toetsen, en passen de manier waarop zij studeren aan de toetsvorm. 
Bij probleemgestuurd onderwijs veronderstellen de in de onderwijsgroep geformuleerde leerdoelen de studie-activiteiten van studenten te sturen in plaats van de verwachtingen die studenten hebben ten aanzien van toetsing (Van der Vleuten, Scherpbier, et al., 1996). Studenten worden verondersteld actief de problemen uit taken en cases op te lossen, kritisch te reflecteren op de informatie die zij opzoeken en tijdens onderwijsgroepen en colleges horen, verbanden te zoeken, etc. (zie hoofdstuk 3). De gebruikte toetsvorm dient bij voorkeur dit studiegedrag te belonen, maar in elk geval zodanig te zijn dat deze leidt tot studie-activiteiten en studiegedrag die niet ten koste gaan van de reguliere voorbereiding op de onderwijsgroepsbijeenkomsten.

Toetsing binnen probleemgestuurd onderwijs stelt een aantal eisen aan de toetsinhoud. Vanwege het feit dat hetgeen door studenten wordt bestudeerd varieert als consequentie van de individuele leerdoelen mag de inhoud van de toets niet leiden tot studiegedrag in de richting van datgene wat studenten in de toets verwachten (Swanson et al., 1991). Volgens deze auteurs moet bovendien het soort kennis worden getoetst dat zich ontwikkelt over een langere periode. Dit betekent dat de inhoud van de vragen moet zijn gericht op samengestelde, samenhangende of ontwikkelde kennis in plaats van op niet-geintegreerde kennis of kennis van feiten. Hoewel binnen probleemgestuurd onderwijs een belangrijk accent ligt op het aanleren van vaardigheden als zelfsturend vermogen en levenslang leren is ook binnen probleemgestuurd onderwijs het toetsen van kennis belangrijk (Norman, 1991). Niet alleen de studenten zelf, maar ook de faculteit en de overheid moeten zien dat de studenten ook over voldoende parate kennis beschikken.

De voortgangstoets heeft een aantal kenmerken waarom deze aan bovengenoemde eisen zou voldoen, namelijk: (1) de omvang van de toets is zodanig groot dat de inhoud ervan de (cognitieve-) eindtermen van de opleiding weerspiegelt en voorkomt dat studenten kunnen gaan bestuderen wat zij verwachten dat zal worden getoetst, (2) de vraagvorm van het type juist/?/onjuist geeft studenten de mogelijkheid zonder consequenties vragen waarover zij geen kennis hebben over te slaan en laat daarmee tevens vrijheid aan welke onderwerpen worden bestudeerd, (3) alle studenten, ongeacht studiejaar of afstudeerrichting, maken dezelfde toets op vaste tijdstippen in het jaar waarmee studenten inzicht krijgen in hoeverre hun kennis zich heeft ontwikkeld in de richting van de eindtermen (Van der Vleuten, Verwijnen \& Wijnen, 1996). 
Inmiddels zijn er enige studies verricht waarin de invloed van de voortgangstoets op studie-activiteiten is onderzocht. In een studie van Geerligs (Van Berkel et al., 1995; Geerligs, 1993), verricht bij de Faculteit der Gezondheidswetenschappen, is aan studenten gevraagd in hoeverre in hun studieactiviteiten door de voortgangstoets worden beïnvloed. Studenten rapporteren dat zij zich ten aanzien van studietijd en studiebelasting niet door de voortgangstoets onder druk gezet voelen. Toch rapporteren veel studenten dat zij zich op de toets voorbereiden door oude toetsen te maken. Het bestuderen van teksten als voorbereiding op de toets wordt door weinig studenten gedaan. Invoering van een toets vergelijkbaar met de Maastrichtse voortgangstoets in McMaster, de 'Personal Progress Index', resulteerde niet in een verandering van leerstijl (Blake et al., 1996). Een vergelijking met jaargroepen vijf jaar voorafgaande aan de toetsintroductie op vragenlijsten naar leerstijlen laat geen verschuiving zien naar memoriserend leren, ten koste van begrijpend leren. $75 \%$ van de studenten rapporteert zich totaal niet op de toets voor te bereiden en $15 \%$ besteedt minder dan vijf uur aan de voorbereiding. Volgens $73 \%$ van de studenten heeft de toets geen enkel effect op het functioneren van de onderwijsgroepen (Blake et al., 1996).

\section{Vraagstellingen en veronderstellingen}

De eerder genoemde probleemstelling in welke mate worden de studie-activiteiten van studenten gestuurd door de voortgangstoets en in hoeverre zijn deze (eventuele) activiteiten gerelateerd aan de prestaties op de voortgangstoets' valt uiteen in een aantal vraagstellingen.

Volgens de doelstelling van probleemgestuurd onderwijs worden de studieactiviteiten wan studenten aangestuurd vanuit de onderwijsgroepen. Elke aansturing vanuit de voortgangstoets kan vanuit deze doelstelling ongewenst worden geacht. De voortgangstoets veronderstelt dan ook niet tot studieactiviteiten aan te sturen. De volgende vraagstelling vloeit hieruit voort.

1. In welke mate vindt er sturing van studie-activiteiten plaats vanuit de voortgangstoets en in hoeverre gaan deze studie-activiteiten ten koste van studie-activiteiten die voortkomen uit de onderwijsgroepsbijeenkomsten?

Bekend is dat een aantal studenten zich ook voorbereiden op de Maastrichtse voortgangstoets (onder andere Van Berkel et al., 1995), maar onduidelijk is hoeveel tijd studenten hieraan besteden. Indien de omvang in tijd groot is 
geeft dit niet alleen iets aan over de aanwezige sturing, maar zal de kans toenemen dat dit gaat ten koste van de reguliere onderwijsactiviteiten.

Naast deze vraag is van belang tot welk soort studie-activiteiten de toetsafname aanleiding geeft bij studenten. In de volgende vraagstelling staan de activiteiten die worden verricht als voorbereiding op de voortgangstoets centraal.

2. Wat is het soort van studie-activiteiten die worden verricht in de voorbereiding op de voortgangstoets, naast de reguliere onderwijsactiviteiten? Studie-activiteiten gericht op globaal herhalen van de stof zijn activiteiten die enige aansluiting hebben bij activiteiten die binnen probleemgestuurd onderwijs passen. Andere activiteiten, bijwoorbeeld gericht bepaalde onderwerpen bestuderen omdat je weet dat er altijd vragen over worden gesteld, worden hoogst waarschijnlijk sterk ingegeven door verwachtingen die er bestaan over de inhoud van de toets. Specifieke voorbereiding op de voortgangstoets met kenmerken als bijwoorbeeld (doel-) gericht, relaterend, begrijpend en/of actief studeren liggen meer in het verlengde van probleemgestuurd leren en zijn minder ongewenst dan studie-activiteiten die bijwoorbeeld ongericht, oppervlakkig en/of memoriserend zijn.

Het te toetsen kennisdomein betekent voor een student wellicht het niveau dat wordt geacht te worden beheerst (relatieve goed-min-fout van de betreffende jaargroep) vergelijkbaar met de jaargenoten. Aan het begin van de studie is de kennis die inmiddels is behandeld kleiner dan aan het einde van de studie. Hiermee zal de veronderstelling 'niet weten waar te beginnen' hoogstwaarschijnlijk voor een eerstejaars minder opgaan dan voor een vierdejaars.

Voor een gedeelte van de studenten geldt dat er geen sturende werking uitgaat van de voortgangstoets. $Z$ ij studeren overeenkomstig de veronderstellingen niet voor de voortgangstoets. Aan dit gedrag zullen veronderstellingen over de toets en verwachtingen over effecten van studie-activiteiten ten grondslag liggen. Welke dit zijn is nagegaan in de volgende vraagstelling.

3. Welke redenen spelen voor studenten waarbij er geen sturing uitgaat van de voortgangstoets een rol om niet te studeren en wat zijn hun verwachtingen ten aanzien van het nut van de diverse gerichte studie-activiteiten?

Naast sturing van studie-activiteiten als gevolg van wisselende inschatting van kennisdomein of vereist kennisniveau of verwachtingen over effecten van 
studie-activiteiten spelen eerdere ervaringen met de toets wellicht een rol. Te denken valt aan eerdere toetsresultaten, maar ook aan ervaringen met de voorbereiding op eerdere toetsafnames. De eerder beschreven studie naar regelmaat van studie-activiteiten indiceerde een grote diversiteit aan studieactiviteiten ter voorbereiding op de voortgangstoets (zie hoofdstuk 4). Naast verschil in doelgerichtheid (bijwoorbeeld vanuit gerichte (toets-)vragen of globaal bepaalde teksten doorlezen), bleek een variatie in wijze van verwerking (actief discussiëren/vragen maken of globaal aantekeningen 'doorbladeren') en gebruikte aanpak. De relatie tussen toetsresultaten en toetsvoorbereiding op de voortgangstoets is onderwerp van de volgende vraagstelling.

4. Bestaat er een relatie tussen (eerdere) toetsresultaten en verrichte voorbereiding op de voortgangstoets?

Studenten met minder goede toetsresultaten voelen zich wellicht genoodzaakt gericht voor de toets te gaan studeren. Anderszins kunnen studenten in het verleden goede ervaringen hebben met zich voor te bereiden op de toets en om die reden besluiten dit bij een volgende toetsafname wederom te doen. De diverse wijzen van voorbereiding kunnen tot verschillende resultaten leiden. Uitspraken over oorzaak dan wel gevolg zijn op basis van beschrijvend onderzoek onmogelijk te doen.

\section{Methode}

\section{Procedure}

In deze studie is na afloop van de tweede voortgangstoets van het studiejaar 1996-1997 (maart 1997) een vragenlijst afgenomen bij alle studenten Gezondheidswetenschappen waarmee is geïnventariseerd welke studie-activiteiten studenten ondernemen in hun voorbereiding op de voortgangstoets. Met de vragenlijst is retrospectief gevraagd naar feitelijk ondernomen studieactiviteiten. Deelname vond plaats op basis van vrijwilligheid, met een kleine beloning in de vorm van een reep chocolade. Beantwoording vormde nauwelijks een belasting voor de studenten.

\section{Populatie}

De vragenlijst is voorgelegd aan alle 998 studenten Gezondheidswetenschappen, ongeacht jaargroep en afstudeerrichting, die de tweede voortgangstoets 
van studiejaar 1996-1997 hebben afgelegd en is geretourneerd door 952 studenten (respons $95.4 \%$ ).

\section{Materiallen}

Vragenlijst aard en omvang studeren voor de voortgangstoets

Ten behoeve van het onderzoek is een schriftelijke vragenlijst ontworpen bestaande uit twee delen: een deel met vragen voor studenten die wel studeren voor de voortgangstoets en een deel voor studenten die niet studeren voor de voortgangstoets.

Het gedeelte voor studenten die wel studeren voor de voortgangstoets bevatte vragen naar het al of niet verrichten van bepalde studie-activiteiten. Op basis van eerder verkregen antwoorden op de vraag 'mijn voorbereiding op de voortgangstoets was als volgt' zijn zeven clusters van studie-activiteiten geformuleerd (gesteld in het in hoofdstuk 4 beschreven onderzoek). Vervolgens is aan studenten gevraagd per cluster van studie-activiteiten een schatting te geven van het aantal minuten dat hieraan is besteed. Aan deze vragen werden twee vragen toegevoegd: éen waarin is gevraagd naar de overeenstemming van de wijze van voorbereiding met de eigen intentie en één waarin de vraag is gesteld of de toetswoorbereiding ten koste is gegaan van andere onderwijsactiviteiten.

De vragen voor studenten die niet voor de voortgangstoets studeren bestonden uit een opsomming van tien redenen om niet te studeren, waaraan gekoppeld de vraag (op een vijfpuntsschaal) te scoren welk belang zij hechten aan elk van de genoemde redenen. De tweede vraag bestond uit een opsomming van acht studie-activiteiten, waaraan gekoppeld de wraag (op een vijfpuntsschaal) een inschatting te maken over hoe zinvol zij deze activiteiten achtten voor het behalen van een hogere voortgangstoetsscore.

De vragenlijst is vooraf getest op duidelijkheid van de vragen en volledigheid van de benoemde studie-activiteiten bij 10 studenten.

\section{Analyse}

De vraagstellingen omtrent het aantal studenten dat voor de voortgangstoets studeert, de aard van en hoeveelheid tijd besteed aan gerichte studie-activiteiten in voorbereiding op de voortgangstoets, naast de opvattingen over 
gerichte studie-activiteiten van studenten die niet studeren, worden beantwoord met beschrijvende statistiek.

Verschillen tussen studenten die wel en niet studeren voor de voortgangstoets zijn getoetst met behulp van t-testen, waarbij binnen jaargroepen is vergeleken. Toetsscores van studenten met verschillende wijze van toetsvoorbereiding zullen worden beschreven, evenals verschillen tussen jaargroepen in aard en voorkomen van gerichte studie-activiteiten.

\section{Resultaten}

\section{Omvang van de sturing door de voortgangstoets}

In tabel 5.1 wordt weergeven door hoeveel studenten gericht wordt gestudeerd voor de voortgangstoets.

Tabel 5.1 Percentage studenten dat gericht studeert voor de voortgangstoets (met tussen haakjes het aantal studenten dat betreffende activiteit verricht)

\begin{tabular}{|c|c|c|c|c|c|}
\hline & totaal & jaar 1 & jaar 2 & jaar 3 & jaar 4 \\
\hline niet studeren & $58.0 \quad(553)$ & $47.5 \quad(114)$ & $55.7(151)$ & $66.1(+27)$ & $63.1(152)$ \\
\hline wel studeren ${ }^{a}$ & $42.0 \quad(401)$ & $52.5(126)$ & $44.3(120)$ & $33.9 \quad(65)$ & $36.9 \quad(89)$ \\
\hline - niet ten koste van averige & $72.6(289)$ & $82.5(104)$ & $65.0 \quad(76)$ & $64.6 \quad(42)$ & 74.2 \\
\hline - wel ten koste van overige & $27.4(109)$ & 17.5 & $35.0 \quad(41)$ & 35.4 (23) & 25.8 \\
\hline
\end{tabular}

${ }^{\circ}$ onderverdeeld in wel versus niet ten koste van overige studie-activiteiten

Ruim veertig procent van de studenten studeert gericht voor de voortgangstoets. Dit percentage is het hoogst in het eerste studiejaar (52.5) en neemt geleidelijk af tot bijna $34 \%$ in de latere studiejaren. In het laatste studiejaar wordt weer door iets meer studenten voor de toets gestudeerd. Bij de meeste studenten die voor de toets studeren gaat dit naar eigen zeggen niet ten koste van hun overige studie-activiteiten. Bij 'slechts' $27.4 \%$ van de eerdere $42 \%$ studenten die zich voorbereiden (11.4\% van alle studenten), gaat de voorbereiding ten koste van hun overige onderwijsactiviteiten.

In tabel 5.2 is weergegeven hoeveel tijd gemiddeld aan de verschillende studie-activiteiten wordt besteed. De vetgedrukte regel betreft het totaal van elk van de zeven clusters, waarna de onderverdeling naar specifieke activiteiten wordt gegeven. 
Tabel 5.2 Aantal studenten dat een bepaalde studie-activiteit onderneemt en de gemiddelde hoeveellheid tijd in minuten die aan deze studie-activiteiten wordt besteed

\begin{tabular}{|c|c|c|c|c|c|}
\hline \multirow[b]{2}{*}{ Totaal aantal uren besteed aan studeren } & \multicolumn{2}{|c|}{ gem $\min$} & \multicolumn{3}{|c|}{$\max \mathrm{N}$} \\
\hline & 183.0 & 204.8 & 5 & 1860 & 401 \\
\hline Doomemen van blokaantekeningen & 122.4 & 152.5 & 5 & 1440 & 203 \\
\hline - college aantekeningen & 46.4 & 89.3 & 5 & 960 & 129 \\
\hline - antwoorden op leerdoelen & 70.4 & 77.6 & 5 & 480 & 108 \\
\hline - practicum aantekeningen & 13.7 & 9.4 & 5 & 30 & 15 \\
\hline - tijdens blok gemaakte samenvattingen van teksten & 52.6 & 57.9 & 5 & 360 & 115 \\
\hline - overige aantekeningen & 29.4 & 30.3 & 5 & 180 & 80 \\
\hline - aantekeningen van specifieke onderwerpen / specifieke blokken & 37.3 & 75.0 & 5 & 600 & 71 \\
\hline Globaal ter opfrissing doornemen van literatuur / teksten & 49.3 & 58.3 & 5 & 480 & 114 \\
\hline - bepaaide onderwerpen m.a.v. gemaakte vragen bloktoets & 22.1 & 19.1 & 5 & 80 & 22 \\
\hline - bepaalde onderwerpen n.a.v. gemaakte vragen voortgangstoets & 30.1 & 33.4 & 5 & 240 & 77 \\
\hline - bepaalide onderwerpen die de student moeillik vind & 25.5 & 31.1 & 5 & 180 & 42 \\
\hline - bepaaide onderwerpen die volgens de student veel worden gevraagd & 254 & 30.4 & 5 & 240 & 69 \\
\hline Gericht bestuderen van literatuur/teksten met doel op te nemen & 51.2 & 66.1 & 5 & 360 & 68 \\
\hline - bepaalde onderwerpen m.a.v. gemaakte vragen bloktoets & 24.3 & 22.1 & 5 & 80 & 14 \\
\hline - bepaalde onderwerpen n.a.v. gemaakte vragen voortgangstoets & 23.7 & 22.2 & 5 & 120 & 40 \\
\hline - bepaalde onderwerpen die de student moeilijk vind & 32.9 & 51.9 & 5 & 240 & 19 \\
\hline - bepaalde onderwerpen die volgens de student veel worden gevraagd & 29.9 & 59.1 & 5 & 360 & 35 \\
\hline - bepaalde rijtjes / definities en feitjes die waak terugkomen & 16.4 & 16.8 & 5 & 100 & 32 \\
\hline Doornemen / bestuderen van oude bloktoetsen & 71.8 & 87.0 & 5 & 600 & 74 \\
\hline - doornemen van oude bloktoetsvragen & 49.3 & 51.6 & 5 & 300 & 69 \\
\hline - beantwoorden van oude bloktcetsvragen & 45.4 & 51.0 & 5 & 300 & 46 \\
\hline Doornemen / bestuderen van oude voortgangstoetsen & 86.2 & 74.9 & 5 & 600 & 329 \\
\hline - doornemen van oude voortgangstoetsuragen & 51.3 & 52.7 & 5 & 480 & 241 \\
\hline - beantwoorden van oude voortgangstoetsvragen & 66.0 & 54.2 & 5 & 300 & 243 \\
\hline Met medestudenten discussiëren & 58.4 & 67.0 & 5 & 420 & 75 \\
\hline - n.a.y. oude bioktoetsen & 27.7 & 42.4 & 5 & 150 & 11 \\
\hline - n.a.v. oudle voortgangstoetsen & 43.6 & 46.6 & 5 & 180 & 62 \\
\hline - onderwerpen lit voorgaande blokken & 18.2 & 16.8 & 5 & 60 & 27 \\
\hline - meedoen aan VGT-spel & 97.7 & 61.0 & 10 & 200 & 9 \\
\hline
\end{tabular}

Ten aanzien van het doornemen van aantekeningen worden vooral college aantekeningen, antwoorden op leerdoelen en eerder gemaakte samenwattingen van teksten gebruikt. Gemiddeld wordt hier ongeveer twee uur aan besteed. Het doornemen van teksten gebeurt met name als vervolg op het maken van toetswragen en op basis van onderwerpen die veelal in de toets aan bod komen. Studenten besteden hier gemiddeld ongeveer $3 / 4$ uur aan. 
Met het doornemen van oude voortgangstoetsen en het beantwoorden van oude toetsvragen zijh studenten gemiddeld ongeveer $1 \mathrm{t} / 2$ uur bezig. Indien studenten gaan studeren voor de voortgangstoets bestrijkt de totale toetsvoorbereiding gemiddeld drie uur, met enorme verschillen tussen individuele studenten ( $\alpha=3.1$ uur).

\section{Aard van de studie-activiteiten voor de voortgangstoets}

In tabel 5.3 wordt weergegeven welke studie-activiteiten door de 401 studenten die zich voorbereiden op de voortgangstoets worden ondernomen. Per studie-activiteit wordt het percentage studenten gegeven dat zich met betreffende studie-activiteit voorbereidt, uitgesplitst naar jaargroep.

Tabel 5.3 Percentage studenten die zich met een bepaalde studie-activiteit voorbereiden op de voortgangstoets, uitgesplitst naar jaargroep

\begin{tabular}{|c|c|c|c|c|c|}
\hline & $\begin{array}{l}\text { totaal } \\
n=401\end{array}$ & $\begin{array}{l}\text { jaar } \\
n=126\end{array}$ & $\begin{array}{l}\text { jaar } 2 \\
n=120\end{array}$ & $\begin{array}{l}\text { jaar } 3 \\
n=65\end{array}$ & $\begin{array}{l}\text { jaar } 4 \\
\mathrm{n}=89\end{array}$ \\
\hline Doornemen van aantekeningen & $50.4(202)$ & $68.3(86)$ & $48.3 \quad(56)$ & $23.1(15)$ & $50.6 \quad(45)$ \\
\hline Globaal teksten bestuderen & $28.4(114)$ & $23.8 \quad(30)$ & $33.9 \quad(39)$ & $21.9(14)$ & $34.8 \quad(31)$ \\
\hline Gericht teksten doornemen & $17.0(68)$ & $15.1 \quad(19)$ & $18.4(21)$ & $109 \quad(7)$ & $23.6 \quad(21)$ \\
\hline Bestuderen oudeBT-en (alleen) & $18.5(74)$ & $43.7 \quad(55)$ & $12.3(14)$ & 3.1 & $3.4 \quad(3)$ \\
\hline Bestuderen oude VGT-en (alleen) & $81.0(325)$ & $79.4(100)$ & $83.3(100)$ & $89.2 \quad(58)$ & $75.3(67)$ \\
\hline \multicolumn{6}{|l|}{ Met medestudenten discussieren } \\
\hline niv.v oude BT-en en/of VGT-en & $18.5(74)$ & $16.7 \quad(21)$ & 20.0 & $22.6 \quad(14)$ & $17.6 \quad(15)$ \\
\hline
\end{tabular}

Het doornemen van oude voortgangstoetsen wordt het meest frequent gebruikt als voorbereiding op de voortgangstoets $(81.0 \%)$. Ook het doornemen van blokaantekeningen (door $50.4 \%$ ) en het globaal doornemen van teksten $(28.4 \%)$ wordt veelvuldig gedaan in de voorbereiding op de voortgangstoets. In de loop van de studiejaren vindt een verschuiving plaats van de studieactiviteiten. In het eerste jaar wordt in vergelijking met de doctoraal op grotere schaal voorbereid door middel van het doornemen van aantekeningen en oude bloktoetsen, waarbij in de latere jaren iets meer nadruk ligt op de bestudering van teksten.

In tabel 5.4 worden de verschillen in tijdsinvestering voor de verschillende studie-activiteiten over de jaargroepen gepresenteerd. 
Tabel 5.4 Aantal minuten dat studenten aan bepaalde studie-activiteiten besteden, uitgesplitst naar jaargroep (standaard deviatie)

\begin{tabular}{|c|c|c|c|c|c|c|c|c|c|c|}
\hline \multirow[b]{2}{*}{ Doomemen van aantekeningen } & \multicolumn{2}{|c|}{ totalal } & \multicolumn{2}{|c|}{ jaar 1} & \multicolumn{2}{|c|}{ jaat 2} & \multicolumn{2}{|c|}{ jaar 3} & \multicolumn{2}{|c|}{ jaar 4} \\
\hline & 122.4 & $(152.9)$ & 150.9 & $(183.1)$ & 114,0 & $(110.6)$ & 127.3 & $(189.3)$ & 76.7 & $(117,9)$ \\
\hline Globaal teksten bestuderen & 49.3 & $(58.3)$ & 50.8 & $(48.3)$ & 47.1 & $(46,1)$ & 46.4 & $(47.0)$ & 52.1 & $(82.7)$ \\
\hline Gericht tekstern doornemen & 51.2 & $(66.1)$ & 56.6 & $(83.9)$ & 37.6 & $(37.8)$ & 25.7 & $(17,2)$ & 68.4 & $(77.7)$ \\
\hline Eestuderen oude BT-en (alleen) & 71.8 & $(87.0)$ & 80.1 & $(97.6)$ & 43.6 & $(33.0)$ & & * & & * \\
\hline Bestuderen oude VGT-en (alleen) & 86.4 & $(75.2)$ & 81.5 & $(59.0)$ & 829 & $(69.9)$ & 89.8 & $(93.2)$ & 95.8 & $(86.8)$ \\
\hline \multicolumn{11}{|l|}{ Met medestudenten discussieren } \\
\hline ma.v oude BT-en en/of VGT-en & 59.0 & $(67.3)$ & 56.7 & $(90.8)$ & 72.5 & $(63.2)$ & 44.7 & $(39.7)$ & 52.0 & $(57.3)$ \\
\hline Totaal & 183.5 & $(205.5)$ & 233.6 & $(249.3)$ & 172.0 & $(154.3)$ & 135.6 & $(148.1)$ & 162.5 & $(220.3)$ \\
\hline
\end{tabular}

Tijdens het eerste studiejaar is er sprake van de hoogste tijdsinvestering. In de latere jaren wordt minder gestudeerd met een lichte toename in het laatste studiejaar. Het afnemen van de totale studietijd in de loop van de studiejaren wordt met name veroorzaakt door een afname van het aantal minuten dat wordt besteed aan het doornemen van aantekeningen. Er wordt in de loop van de studiejaren meer tijd besteed aan het bestuderen van oude toetsen. Ten aanzien van het bestuderen van teksten is na een daling vanaf het eerste tot en met derde studiejaar een opvallende stijging in het vierde studiejaar waar te nemen.

\section{Relatie tussen toetsresultaten en toetsvoorbereiding}

In tabel 5.5 worden de toetsresultaten van studenten die wel en de studenten die niet studeren voor de voortgangstoets vergeleken, zowel voor de toets waarbij de vragenlijst is afgenomen als de eraan voorafgaande toets.

Bij afname van de eerste voortgangstoets scoorden de studenten die niet studeerden voor de daaropvolgende voortgangstoets over het algemeen iets hoger dan de studenten die voor de tweede toets wel studeerden. De verschillen zijn alleen in het derde studiejaar significant. Ten aanzien van de toetsresultaten op de tweede voortgangstoets geldt dat de studenten uit het eerste en laatste studiejaar die studeren voor de voortgangstoets worden gekenmerkt door (iets) betere prestaties op deze toets. In het eerste jaar zijn de verschillen significant. In jaar twee en drie behalen studenten die niet voor de toets studeren iets hogere scores, waarbij de verschillen niet significant zijn. 
Tabel 5.5 Germiddelde goed score, fout score en goed-min-fout score van studenten, uitgesplitst naar jaargroep en welniet voor de tweede voortgangstoets hebben gestudeerd

\begin{tabular}{|c|c|c|c|c|c|c|c|c|}
\hline & \multicolumn{2}{|c|}{ jaer 1} & \multicolumn{2}{|c|}{ jaar 2} & \multicolumn{2}{|c|}{ jaar 3} & \multicolumn{2}{|c|}{ jaar 4} \\
\hline & well & niet & wel & niet & wel & niet & wel & niet \\
\hline eerste VGT $96 / 97$ & $(n=130)$ & $(n=121)$ & $(n=112)$ & $(n=1,39)$ & $(n=90)$ & $(n=159)$ & $(n=56)$ & $(n=105)$ \\
\hline - Goed-min-fout & 24.5 & $24.3 \mathrm{~ns}$ & 47.5 & $50.1 \mathrm{~ns}$ & 58.9 & 65.4 * & 73.7 & $77.6 \mathrm{~ns}$ \\
\hline - Goed & 43.1 & $45.3 \mathrm{~ns}$ & 73.9 & $80.2 *$ & 100.5 & 109.5 & 122.2 & $1.43 .8^{* * x+1}$ \\
\hline - Fout & 18.6 & $21.0 \mathrm{~ns}$ & 26.5 & $30.1^{*}$ & 41.6 & $44.0 \mathrm{~ns}$ & 48.5 & $66.2^{* * * *}$ \\
\hline tweede VGT 96!97 & $(n=126)$ & $(n=114)$ & $(n=120)$ & $(n=151)$ & $(n=65)$ & $(n=127)$ & $(n=89)$ & $(n=152)$ \\
\hline - Goed-min-fout & 34.7 & $29.1^{* *}$ & 30.6 & $34.0 \mathrm{~ns}$ & 62.5 & $65.5 \mathrm{~ns}$ & 69.2 & $67.8 \mathrm{~ns}$ \\
\hline - Goed & 54.2 & $50.6 \mathrm{ins}$ & 82.7 & $86.4 \mathrm{~ns}$ & 107.2 & $111.0 \mathrm{~ns}$ & 116.3 & $126.8 \mathrm{~ns}$ \\
\hline - Fout & 19.5 & $21.5 \mathrm{~ns}$ & 52.2 & $52.5 \mathrm{~ns}$ & 44.6 & $45.4 \mathrm{~ns}$ & 47.1 & $59.0 *$ \\
\hline
\end{tabular}

Toetsscores en aard van de studie-activiteiten in voorbereiding op de voortgangstoets

In tabel 5.6 worden de goed-min-fout scores weergegeven van studenten die voor de voortgangstoets studeren waarbij een onderverdeling is gemaakt in welke activiteiten zijn ondernomen.

Tabel 5.6 Gemiddelde goed-min-fout scores per studie-activiteit die wel of niet is ondernomen $(n=401)$, uitgesplitst naar jaargroep

\begin{tabular}{|c|c|c|c|c|c|c|c|c|c|c|}
\hline & \multicolumn{2}{|c|}{ totaal } & \multicolumn{2}{|c|}{ jaar 1} & \multicolumn{2}{|c|}{ jaar 2} & \multicolumn{2}{|c|}{ jaar 3} & \multicolumn{2}{|c|}{ jaar 4} \\
\hline & wet & niet & wel & niet & wel & niet & well & nier & we! & niet \\
\hline Doornemen van aantekeningen & 49.9 & $55.0^{*}$ & 33.5 & $38.6 \mathrm{~ns}$ & 52.5 & $51.9 \mathrm{~ns}$ & 68.9 & $61.1 \mathrm{~ns}$ & 71.4 & $67.4 \mathrm{~ns}$ \\
\hline Globaal teksten bestuderen & 54.8 & 51.4 & 35.8 & $34.5 \mathrm{~ns}$ & 55.7 & $50.9 \mathrm{~ns}$ & 63.8 & $62: 3 \mathrm{~ns}$ & 68.4 & $70.5 \mathrm{~ns}$ \\
\hline Gericht telksten doornemen & 54.1 & 52.4 & 30.4 & $35.4 \mathrm{~ns}$ & 52.4 & $52.3 \mathrm{~ns}$ & 72.6 & $61.4 \mathrm{~ns}$ & 69.6 & $69.2 \mathrm{~ns}$ \\
\hline Bestuderen oude BT-en (alleen) & 37.0 & $56.0^{\text {\#** }}$ & 33.0 & $36.2 \mathrm{~ns}$ & 48.4 & $53.1 \mathrm{~ns}$ & $n<5$ & 63.3 & $n<5$ & 70.0 \\
\hline Bestuderen oude VGT-en (alleen) & 52.8 & 51.8 & 35.4 & $34.4 \mathrm{~ns}$ & 53.0 & $49.4 n s$ & 62.3 & $65.3 n s$ & 69.8 & 68.7 \\
\hline \multicolumn{11}{|l|}{ Met medestudenter discussieren } \\
\hline n av oude BT-en en/of VGT-en & 54.0 & 51.7 & 36.7 & $34.4 \mathrm{~ns}$ & 50.2 & $52.9 \mathrm{~ns}$ & 61.4 & $62.4 \mathrm{~ns}$ & 74.8 & $68.6 \mathrm{~ns}$ \\
\hline
\end{tabular}

Binnen de $42 \%$ van de studenten die studeert voor de voortgangstoets (tabel 5.1) behalen studenten die aantekeningen doornemen en oude bloktoetsen bestuderen significant lagere scores dan studenten die zich op een andere wijze voorbereiden. Dit verschil blijkt toe te schrijven aan de variabele jaargroep. Zowel het bestuderen van aantekeningen als het maken van oude 
bloktoetsen wordt in duidelijk grotere aantallen gedaan door eerstejaars studenten. Wanneer binnen de jaargroepen de verschillende studie-activiteiten met elkaar worden vergeleken blijkt dit voor geen enkele studie-activiteit te resulteren in significant hogere toetsprestaties. Bovendien is er voor geen enkele activiteit een duidelijke trend. Een hogere dan wel lagere score halen 'ten gevolge van' een bepaalde studie-activiteit blijkt niet consistent tussen jaargroepen.

\section{Opvattingen om niet voor de toets te studeren}

In tabel 5.7 is weergegeven welke waarde wordt gehecht aan opvattingen om niet voor de toets te studeren door de studenten die dit niet doen.

Tabel 5.7 Gemiddelde waarde die wordt gehecht aan verschillende redenen om niet voor de voortgangstoets te studeren, uitgesplitst naar jaargroep

\begin{tabular}{|c|c|c|c|c|c|}
\hline & 1 & 2 & 3 & 4 & total \\
\hline \multicolumn{6}{|l|}{ (zelf)Studie-activiteiten voor de onderwijsgroep zijn voldoende } \\
\hline voorbereiding op de VGT & 3.6 & 3.6 & 3.6 & 3.5 & $3.6 \mathrm{~ns}$ \\
\hline VGT halen zonder ervoor te studeren & 2.8 & 3.4 & 3.9 & 3.8 & $3.5 *$ \\
\hline Niet aan toe glekomen deze keer & 3.1 & 2.5 & 1.9 & 2.3 & $2.4^{* * *}$ \\
\hline Niet belangrijk genoeg amdat je geen studiepunten krijgt & 2.2 & 2.0 & 2.4 & 2.2 & $2.2 n s$ \\
\hline Niet weten waar te beginnen varwege veelheid onderwerpen & 3.2 & 2.8 & 2.9 & 2.8 & $2.9 \mathrm{~ns}$ \\
\hline VGT toch niet halen & 1.7 & 1.5 & 1.3 & 1.5 & $1.5 * * *$ \\
\hline \multicolumn{6}{|l|}{ Vragen zodanig specifiek dat met gericht studeren vragen niet } \\
\hline beantwoond kunnen worden & 2.6 & 2.6 & 2.6 & 2.6 & $2.6 \mathrm{~ns}$ \\
\hline \multicolumn{6}{|l|}{ Overige ondenwijsactiviteiten, zoals het studeren voor de onder- } \\
\hline wijsgroep, waren belangrijker & 3.5 & 3.6 & 3.5 & 3.4 & $3.5 \mathrm{~ns}$ \\
\hline Niet conform doelstelling van de VGT & 4.0 & 4.0 & 3.9 & 3.8 & $3.9 \mathrm{~ns}$ \\
\hline De VGT bevat vooral algemene wragen nog bekende vragen & 2.8 & 2.8 & 2.7 & 2.7 & $2.8 \mathrm{ng}$ \\
\hline
\end{tabular}

De belangrijkste opvattingen om niet te studeren zijn: 'het is niet de bedoeling van de Voortgangstoets', 'gewone studie-activiteiten zijn een voldoende voorbereiding', 'andere studie-activiteiten (zoals de onderwijsgroep) zijn belangrijker dan het voorbereiden van de toets' en 'de voortgangstoets halen zonder iets voor te doen'. Opvattingen waar weinig belang aan wordt gehecht zijn 'de toets toch niet hallen', 'geen studiepunten voor de toets krijgen' en 'deze keer niet aan toe gekomen'. Aan de opvatting "de voortgangstoets halen zonder er iets voor te doen' wordt in de loop van de studiejaren (significant) 
steeds meer belang gehecht. De opvatting "niet aan toe gekomen deze keer" wordt in de loop van de studiejaren minder belangrijk.

\section{Verwachtingen omtrent effect van voorbereiden voor de voortgangstoets}

Aan de studenten die niet studeerden voor de voortgangstoets is ook gevraagd hoe zinvol de verschillende studie-activiteiten naar hun verwachting ziin woor het behalen van hogere toetsresultaten. In tabel 5.8 worden de resultaten hiervan wergegeven.

Tabel 5.8 Gemiddelden ten aanzien van verwacht effect van verschillende gerichte studie-activiteiten ter voorbereiding op de voortgangstoets, uitgesplitst naar jaargroep

\begin{tabular}{|c|c|c|c|c|c|}
\hline & 1 & 2 & 3 & 4 & totaal \\
\hline Doornemen van aantekeningen uit woorgaande blokken & 3.7 & 3.6 & 3.0 & 3.4 & $3.4^{k \cdots * x}$ \\
\hline Ter opfrissing globaal doomemen van literatuurfteksten & 2.9 & 24 & 2.5 & 2.7 & $2.6 * *$ \\
\hline \multicolumn{6}{|l|}{ Gericht doomemen van literatuur/teksten met als doel } \\
\hline de inhoud op te nemen ('stampen') & 1.9 & 1.6 & 17 & 1.8 & $1.7 \mathrm{~ns}$ \\
\hline Individueel doornemen/bestuderen van oude BT-en & 3.6 & 3.3 & 2.7 & 2.5 & $3.0^{* * *}$ \\
\hline Individueel doornemen/bestuderen wan oude VGT-en & 3.9 & 4.2 & 4.1 & 4.0 & $4.0 \mathrm{~ns}$ \\
\hline \multicolumn{6}{|l|}{ Met medestudenten doornemen van oude bloktoetsen } \\
\hline en discussieren over de antwoorden & 3.6 & 3.2 & 2.7 & 2.7 & $3.0^{ \pm * *}$ \\
\hline \multicolumn{6}{|l|}{ Met medestudenten doornemen van oude voortgangs- } \\
\hline toetsen en discussieren over de antwoorden & 3.8 & 3.7 & 3.7 & 3.6 & $3.7 \mathrm{~ns}$ \\
\hline Deelnemen aan het VGT spel van de studievereniging & 2.4 & 2.5 & 2.6 & 2.5 & $2.5 n 5$ \\
\hline
\end{tabular}

Studenten verwachten het minste effect van 'gericht bepaalde onderwerpen en of feiten inprenten'. Aan 'doomemen van aantekeningen', en individueel of gezamenlijk 'doomemen/bestuderen van oude voortgangstoetsen' worden de hoogste verwachtingen ten aanzien van effect toegekend. In de loop van de studiejaren wordt duidelijk minder verwacht van de effectiviteit van het doomemen van aantekeningen en het individueel of gezamenlijk bestuderen van oude bloktoetsen.

\section{Discussie en conclusie}

Studeren voor de voortgangstoets. In de beschreven studie is nagegaan welke sturing op studie-activiteiten ar van de voortgangstoets uitgaat. De 
veronderstelling dat er weinig sturing is, zoals onder andere geformuleerd door Van der Vleuten, Verwijnen en Wijnen (1996), blijkt slechts ten dele waar. Een aanzienlijk deel van de studenten, ruim $40 \%$, gaat in bepaalde mate en vorm gericht studeren voor de voortgangstoets. Hoewel er veel studenten zijn die zich in bepaalde vorm op de toets voorbereiden, is de hoeveelheid tijd die eraan wordt besteed beperkt, gemiddeld drie uur.

De $40 \%$ studenten die studeert voor de toets is in vergelijking met de $25 \%$ studenten voor de 'Personal Progress Index' in McMaster (Blake, Keane, Norman \& Mueller, 1994] beduidend hoger. De plaats in het curriculum vormt hier hoogstwaarschijnlijk een verklaring voor. Onvoldoende resultaten op de toets hebben in Maastricht (negatieve) studieconsequenties (studiegids Gezondheidswetenschappen, 1996) terwijl studenten in McMaster op basis van onvoldoende resultaten niet kunnen zakken of slagen.

Voor een kwart van de eerder genoemde $40 \%$ die zich op de toets voorbereidt (11\% van het totaal) gaat de voorbereiding ten koste van de voorbereidingstijd voor de onderwijsgroep en lijkt voor deze studenten de zelfsturing die vanuit de onderwijsgroep dient te gaan (Williams, 1992) in het geding. In het perspectief dat $73 \%$ van de studenten antwoordt dat de 'Personal Progress Index' geen invloed heeft op het functioneren van de onderwijsgroep is de 11 $\%$ laag. Dus ondanks aanwezige studieconsequenties is de invloed op het functioneren van de onderwijsgroep laag.

Soort van studie-activiteiten. De studie-activiteiten die ter voorbereiding worden verricht bestaan veelal uit oude aantekeningen doornemen en voortgangstoetsen uit het verleden maken, activiteiten die te maken hebben met globaal bestuderen en/of opfrissen van leerstof. Deze studie-activiteiten zijn betrekkelijk positief, met name gericht op globaal opfrissen kennis. Minder positieve studie-activiteiten zoals uit het hoofd leren van definities of feiten, activiteiten die memoriseren suggereren, komen nauwelijks voor. Hoewel veelal wordt gesuggereerd dat gesloten vragen slechts aanleiding geven tot memoriserend studiegedrag gericht op korte termijn herkenning blijkt opnieuw, evenals in de studie van Yang et al. (1985), dat gesloten vragen ook aanleiding kunnen geven tot meer wenselijk studiegedrag. De plaats en functie binnen het curriculum lijkt meer van belang. Studenten spreken in de studie van Zeidner (1987) hun voorkeur uit voor open vragen boven multiple choice vragen omdat deze in hun beleving een beter hun kennis weergeven. 
In het perspectief van het soort voorbereiding op de voortgangstoets zijn de bevindingen van Richards en Cairaga (1994) interessant. Studenten uit een probleemgestuurd curriculum besteden in vergelijking tot studenten uit traditionele curricula meer tijd aan de voorbereiding op het landelijk examen. Ondanks hun gevoel dat ze met hun probleemgestuurd onderwijs onvoldoende kennis hebben gekregen blijven ze in de voorbereiding veel nadruk leggen op het leren van concepten in plaats van memoriseren. De werkwijze in probleemgestuurd onderwijs lijkt eraan bij te dragen dat studenten minder terugvallen op en/of vertrouwen hebben in memoriserend leren.

De veronderstelling dat er geen sturing uitgaat van de toets vanwege het brede te toetsen kennisdomein (Van der Vleuten, Scherpbier, et al, 1996) blijkt voor de voortgangstoets van Gezondheidswetenschappen twijfelachtig. Bij de propedeuse studenten is sprake van een sterkere sturing door de voortgangstoets. Het argument 'niet weten waar te beginnen' geldt indien wordt uitgegaan van het vereiste kennisniveau aan het einde van de studie. Het vereiste kennisniveau aan het begin van de studie (het relatieve aantal goed-min-fout van de eigen jaargroep) is daarmee nog wel te overzien. De introductie van de propedeuse-module sinds 1995 heeft aan deze herkenbaarheid van een betrekkelijk afgebakend 'wel te overzien waar te beginnen' kennisdomein bijgedragen.

De voorbereiding van propedeuse studenten lijkt ook gerichter en meer afgebakend van aard. In vergelijking met hogere jaars bereiden zij zich vaker voor in de vorm van bloktoetsen maken en doornemen van blokaantekeningen. In de loop van de studie wordt de voorbereiding meer globaal van aard, in de vorm van het bestuderen van oude voortgangstoetsen. Mogelijk speelt bij propedeuse studenten de onbekendheid met voortgangstoetsing een rol. Een toets maken zonder ervoor te hoeven/kunnen studeren is tegenintuïtief en zal hoogst waarschijnlijk niet overeenkomen met ervaringen die zij tot dan toe hebben met toetsen.

Overwegingen om niet toetsgericht te studeren. De overwegingen van studenten om niet specifiek voor de voortgangstoets te studeren komen sterk overeen met de veronderstelde bedoeling van de toets; 'niet de bedoeling om te studeren', 'gewone studie-activiteiten zijn voldoende' en 'andere studie-activiteiten zijn belangrijker'. Het toenemende belang dat in de loop van de studie-jaren wordt gehecht aan 'de toets halen zonder ervoor te studeren' en het 
afnemende belang voor 'eigenlijk vinden dat er wel gestudeerd zou moeten worden', illustreren de invloed van (ontbrekende) ervaring met voortgangstoetsing. Deze bevinding geldt echter alleen voor studenten die zich niet voorbereiden op de voortgangstoetsen en ligt mogelijk anders bij studenten die wel gericht gaan studeren voor de voortgangstoets.

Verrichte voorbereiding en toetsresultaten. Ten aanzien van toetsvoorbereiding en toetsresultaten is de samenhang onduidelijk. Hoewel in de studies naar probleemgestuurd studiegedrag en regelmaat van studie-activiteiten de suggestie ontstond dat met name studenten met minder goede toetsresultaten geneigd zijn gericht te studeren voor de voortgangstoets (zie hoofdstuk 3 \& 4) blijkt dat in de in dit hoofdstuk beschreven studie niet helder. Het is goed mogelijk dat met name studenten met mindere toetsprestaties zich genoodzaakt voelen tot toetsgerichte voorbereiding. In de vier jaargroepen behaalden dan weer de studenten die niet studeerden voor de toets of dan weer de studenten die wel studeerden voor deze toets, hogere scores op de toets. Ook op de eraan voorafgaande toets is geen consistent beeld in hogere dan wel lagere toetsresultaten voor éen van beide groepen. Bovendien is niet bekend hoe stabiel wel of niet woorbereiden is tussen verschillende toetsafnames. Ook binnen de groep studenten die voor de toets heeft gestudeerd zijn geen aanwijzingen van een eventuele positieve invloed op studieresultaten van één van toetsvoorbereidende studie-activiteiten.

Geconcludeerd kan worden dat een betrekkelijk hoog percentage studenten zich gericht voorbereid op de voortgangstoets. De omvang van deze activiteiten in tijdsinvestering is echter beperkt tot gemiddeld drie uur, waarbij het soort activiteiten niet de meest ongewenste is. De activiteiten zijn vooral gericht op het opfrissen van kennis. Bovendien is het percentage studenten dat aangeeft hun studie-activiteiten voor de voortgangstoets te verrichten ten koste van studie-activiteiten voor de onderwijsgroep ook beperkt. Op basis van de resultaten in dit onderzoek ontbreken duidelijke aanwijzingen over het wel of niet ontbreken van een positief effect van gerichte studie-activiteiten op voortgangstoetsresultaten. 



\section{Toetsgerichte studie-activiteiten: een interventie-studie naar de invloed op voortgangstoetsresultaten}

In dit zesde hoofdstuk wordt een studie beschreven waarin nader is onderzocht in hoeverre specifieke voorbereiding voor de voortgangstoets invloed heeft op het behalen van hogere toetsresultaten. De resultaten van de hier gepresenteerde studie zijn gebaseerd op een gerandomiseerde interventiestudie met een twee bij drie design welke is gehouden onder 123 tweedejaars Gezondheidswetenschappen. Studenten zijn volgens dit design willekeurig toegewezen aan drie onderzoekscondities; bestuderen van oude aantekeningen, in groepjes maken van oude toetsuragen en de controle-conditie niet studeren, met als achtergrondsvariabele wel of niet studeren voor voorafgaande voortgangstoets (studiejaar 1996-1997). Tevens is bij deze studenten een vragenlijst afgenomen over hun probleemgestuurd studiegedrag waarmee is onderzocht of dit is gerelateerd aan toetsvoorbereiding.

\section{Inleiding en probleemstellingen}

De voortgangstoets als wijze van toetsing veronderstelt geen invloed te hebber op het studiegedrag van studenten. Een aantal kenmerken van de toets zou hierbij een rol spelen. Als eerste het feit dat de toetsafnames onalhankelijk is van het onderwijs dat (inmiddels) is gevolgd of vordering in de studie. Daarnaast is de inhoud de toets zodanig breed dat studenten niet weten waar te beginnen (Van der Vleuten, Verwijnen \& Wijnen, 1996). Bovendien is het de bedoeling dat de toetsitems niet vragen naar kleine feiten maar kennis die ontstaat en opgebouwd is over een langere periode (Van der Vleuten, Scherpbier, et al., 1996).

Toch blijken betrekkelijk grote aantallen studenten voor de voortgangstoets te studeren (zie hoofdstuk 5). Uit het argument dat de toetsitems niet vragen naar kleine feiten maar naar kennis die over een langere periode wordt 
opgebouwd volgt de veronderstelling dat gerichte voorbereiding op de toets geen of weinig effect heeft. De centrale probleemstelling van het onderzoek luidt: "is er een effect van gerichte studie-activiteiten in voorbereiding op de voortgangstoets op het toetsresultaat?"

\section{Achtergrond toetsgerichte studie-activiteiten}

Van der Vleuten, Verwijnen en Wijnen (1996) stellen dat de aaneengeschakelde voorbereiding van de onderwijsgroepen met zich mee brengt dat studenten hun kennis automatisch zien toenemen. Toch blijkt uit eerdere studies dat de 'voorbereiding' van studenten op de voortgangstoets niet beperkt blijft tot studie-activiteiten voor en in de onderwijsgroep, maar dat studenten bovendien specifiek ervoor gaan studeren. Daarbij is onduidelijk in welk opzicht er een compenserende werking van specifiek studeren ten opzichte van de onderwijsgroepsactiviteiten uit gaat.

In de studie naar probleemgestuurd studiegedrag (Van Til, Van der Vleuten 8. Van Berkel, 1997a; zie ook hoofdstuk 3) blijken type probleemgestuurd studiegedrag en studeren voor de voortgangstoets weinig aan elkaar gerelateerd. Wel blijken studenten met het type 'oppervlakkig actief' en 'diep passief' meer uren te studeren voor de toets en zich in hogere mate te herkennen in een gedragsprofiel met studie-activiteiten dat zich sterk laat kenmerken door studeren voor de toets. In een regressie analyse blijkt toetsvoorbereiding geen significante toevoeging in de verklaarde variantie van voortgangstoetsresultaten, terwiil dit voor probleemgestuurd studiegedrag wel het geval blijkt. Door de negatieve correlatie tussen specifieke toetsvoorbereiding en toetsresultaten ontstaat eerder de suggestie dat met name de studenten met minder goede toetsresultaten specifiek voor de toets gaan studeren. Op basis van bovenstaande rijst de vraag of de aard van de studie-activiteiten (diep versus oppervlakkig) wel is te compenseren met specifieke toetsvoorbereiding, maar de meerwaarde van actieve deelname niet.

In de verrichte studie naar regelmaat van studie-activiteiten (zie hoofdstuk 4) wordt opnieuw bevestigd dat probleemgestuurd studiegedrag een toegevoegde waarde heeft op voortgangstoetsresultaten. Dit terwijl de spreiding van studie-activiteiten, de aaneengeschakelde voorbereiding voor de onderwijsgroep, minder van belang blijkt. Tegen de verwachting in blijkt er in deze studie nauwelijks een verband te bestaan tussen de spreiding van activiteiten voor de onderwijsgroep en specifieke voorbereiding voor de voortgangs- 
toets. Ditmaal blijkt er een positieve correlatie tussen specifieke voorbereiding voor de voortgangstoets met de toetsresultaten.

In de studie waarin de omvang van de sturende werking van de voortgangstoets is geinventariseerd (zie hoofdstuk 5) wordt vervolgens geconcludeerd dat de samenhang tussen wel of niet studeren voor de voortgangstoets en toetsresultaten uiterst dubieus is. Zo blijken tussen jaargroepen afwisselend de studenten die niet studeerden voor de toets dan wel studenten die wel studeerden voor de toets betere toetsresultaten te hebben. Bij vergelijkingen op de voorgaande en de volgende toets blijkt dat deze verschillen zich op groepsniveau niet stabiel in dezelfde richting voordoen en lijken deze verschillen moeilijk te verklaren. Twee factoren die hierop van invloed kunnen zijn worden geopperd. Mogelijk gaan juist de studenten met minder goede resultaten studeren. Een andere factor vormt de mogelijkheid dat studenten met goede resultaten nog betere resultaten zouden behalen wanneer zij zich specifiek zouden gaan voorbereiden op de toets.

\section{Vraagstellingen en veronderstellingen}

Op basis van de eerder verrichte studies is niet geheel duidelijk of studenten die zich voorbereiden op de voortgangstoets qua studieresultaten verschillen van studenten die dit niet doen. Daarnaast zijn in de eerdere verrichte studies effecten van de aard en activiteit van probleemgestuurd studiegedrag op voortgangstoetsresultaten gevonden.

De onderlinge samenhang tussen deze variabelen is in bovenstaande studies niet expliciet onderzocht. De eerste vraagsteling komt hieruit voort.

1. Onderscheiden studenten die zich voorbereiden op de voortgangstoets zich van studenten die dit niet doen wat betreft probleemgestuurd studiegedrag en competentie op de voortgangstoets?

Het uitgangspunt dat binnen probleemgestuurd onderwijs de voorbereiding op en deelname aan de onderwijsgroep tevens voldoende voorbereidt op de voortgangstoets, doet veronderstellen dat studenten die niet studeren voor de voortgangstoets gekenmerkt worden door wenselijker studiegedrag, studiegedrag dat gekenmerkt wordt door een diepere en actievere opstelling in de onderwijsgroep en tijdens de zelfstudie.

Het bestuderen van oude blokaantekeningen en het individueel bestuderen van oude voortgangstoetsen zijn de meest ondernomen studieactiviteiten in de toetsvoorbereiding. Aan deze studie-activiteitern wordt door studenten die 
zich niet voorbereiden op de voortgangstoets ook het hoogste verwachte effect toegekend (zie hoofdstuk 5). Ook bestudering van oude voortgangstoetsen wordt aangemerkt als een studieactiviteit die effect kan hebben, waarbij iets meer wordt verwacht van gezamenlijk bestuderen ten opzichte van individueel bestuderen (eveneens hoofdstuk 5). Aangezien aan deze wijze van voorbereiding de hoogste verwachtingen worden toegekend zullen deze nader worden onderzocht.

2. Wat is het effect van de gerichte studieactiviteiten voor de voortgangstoets; (a) bestuderen van oude aantekeningen en (b) gezamenlijk bestuderen van oude voortgangstoetsen, op de toetscores?

Gezamenlijk bestuderen van oude voortgangstoetsen wordt door studenten gebruikt als 'ingang' om naar aanleiding van de vragen te discussiëren over de antwoorden (zie hoofdstuk 5). Dit veronderstelt een op actieve wijze bestaande kennis activeren en aan elkaar overgedragen, waarbij feedback aan elkaar wordt gegeven omtrent de juistheid van de kennis. Ook het bestuderen van aantekeningen wordt door studenten veelal gebruikt om eerder behandelde leerstof te herhalen en op te frissen. Bij deze wijze van voorbereiding ontbreekt de component actief informatie en feedback geven en ontvangen, welke een extra leereffect met zich mee zou kunnen brengen.

\section{Methode}

\section{Procedure}

In deze gerandomiseerde interventie-studie is volgens een twee-bij-drie design het effect van specifiek studeren voor de voortgangstoets onderzocht. In de studie is gebruik gemaakt van achtergrondvariabelen van studenten die zijn verkregen tijdens de afname van de tweede voortgangstoets van studiejaar 1.996-1997 (zie hoofdstuk 5). In de studie wordt onderscheid gemaakt tussen studenten die zich wel en studenten die zich niet voorbereidden op de tweede voortgangstoets van studiejaar 1996-1997. Studenten zijn binnen deze twee groepen random toegewezen aan drie verschillende interventie-condities. De interventie-condities bestonden uit een studieopdracht, (1) bestuderen van aantekeningen of (2) in kleine groepjes bestuderen van oude toetsen en (3) een controle conditie. In totaal is er sprake van 
zes groepen. Het effect van de studie-opdrachten is gemeten met de afname van een oude voortgangstoets.

Deelname aan deze studie vond plaats op basis van vrijwilligheid tegen een beloning van twee bioscoopbonnen. Het resultaat op de interventie-toets had in deze studie geen studie-consequenties. De interventie-studie vond plaats in de periode die wooraf ging aan de derde voortgangstoets van dat studiejaar.

\section{Steekproeftrekking en populatie}

In totaal hebben 123 van de 271 tweedejaars studenten deelgenomen aan de interventie-studie: 62 studenten (van de 120 ) die zich hadden voorbereid op de voorafgaande voortgangtoets en 61 studenten (van de 151) die zich op geen enkele wijze hadden voorbereid op de voorafgaande toets. De keuze voor studenten uit slechts éen jaargroep is gemaakt ter voorkoming van bias bimmen het design ten gevolge van vordering in de studie. De keuze voor tweedejaars studenten als onderzoekspopulatie is bepaald door de veronderstelling dat deze groep bekend is met de voortgangstoets en inmiddels een betrekkelijk stabiel voorbereidingspatroon voor de voortgangstoets zal hebben ontwikkeld. Bovendien is het kennisdomein dat inmiddels in de studie aan bod is gekomen aan het begin van de studie minder omvangrijk en daarmee 'redelijk te overzien waar te beginnen'. Een eventueel effect van studeren zal in de lagere jaren het meest waarschijnlijk zijn.

Bij het selecteren van studenten zijn twee steekproeven genomen: éen uit de studenten die wel studeerden voor de voorgaande toets en één uit de studenten die dit niet deden. De steekproeven zijn representatief op resultaten op de laatste twee voortgangstoetsen en (indien van toepassing) de hoeveelheid voorbereidingstijd op de voorgaande toets (zie tabel 6.1). Binnen deze twee selecties zijn studenten random aan éen van de drie interventie-condities toegewezen, door studenten te rangschikken op voorgaande toetsresultaten en om en om in te delen. Om groepsgrootte en vergelijkbaarheid wan de groepen te handhaven zijn studenten die na een eerdere toezegging alsnog afzagen van deelname $(\mathrm{n}=9)$ gematcht met op achtergrondvariabelen vergelijkbare studenten. 
Tabel 6.1 Representativiteit steekproef ten aanzien van goed-min-fout scores op de eerste en tweede voortgangstoets van studiejaar 1996-1997 en aantal minuten voorbereiding op de tweede voortgangstoets

\begin{tabular}{|c|c|c|c|c|}
\hline & \multicolumn{2}{|c|}{ studeerde we woor 2 VGT' $\mathrm{VG}$} & \multicolumn{2}{|c|}{ studeerde niet voor 2 VGT 96} \\
\hline & $\begin{array}{c}\text { deselname } \\
(n=61)\end{array}$ & $\begin{array}{l}\text { niet deelname } \\
\qquad(n=59)\end{array}$ & $\begin{array}{c}\text { deelname } \\
(n=62)\end{array}$ & $\begin{array}{l}\text { niet deelname } \\
\qquad(n=79)\end{array}$ \\
\hline GminF 1 VGT 96 & 45.3 & $47.8 \mathrm{~ns}$ & 47.9 & $50.5 \mathrm{~ns}$ \\
\hline GminF $2^{\circ}$ VGT 96 & 52.5 & $51.8 \mathrm{~ns}$ & 52.8 & $52.9 \mathrm{~ns}$ \\
\hline OminF $3^{\circ}$ VGT' 96 & 48.8 & $51.1 \mathrm{~ns}$ & 50.2 & $48.4 \mathrm{~ns}$ \\
\hline Studietijd $2^{\circ} \vee T^{~} 96$ & 157.9 & $177.8 \mathrm{~ns}$ & - & - \\
\hline
\end{tabular}

Voor aanvang van het onderzoek zijn studenten die deelnamen schriftelijk op de hoogte gesteld van de procedure en de interventie. De interventie en de interveritie-toets hebben plaatsgevonden op dezelfde dag.

\section{Materialen}

\section{Interventies}

De drie interventies: bestuderen van aantekeningen, gezamenliik oude voortgangstoetsen bestuderen en de controle interventie worden hieronder toegelicht.

Bestuderen van aantekeningen. De studenten in deze groep ontvingen schriftelijk de opdracht op de dag van het onderzoek, of de daaraan voorafgaande dag, thuis oude aantekeningen te bestuderen volgens de instructie weergegeven in figuur 6.1 .

Bestudeer thuis je oude aantekeningen met een totaal van éen uur (effectiove siludeertijd, exclusief pauze). Dif kan bestaan wit het doomemen wan antwoorden op leerdoelen, gemaakte samenvaltingen, college-aantekeningen, atc Bopaal voor jezelf of je dit doet van al je biokken, bepaalde blokken of bepaalde onderwerpen. Je mag hierbij oude toetsen als insteek gebruiken om te bepalen wat je gaat bestuderen. Met maakt niet uit of je je aantekeningen globaal doorteest of acht besiudeert. Bereid je zo optimaal mogelijk voor met het bestuderen van aantekeningen. Howdje aan de opdracht en studeer daarbil niet meer en niet minder dan én uur.

Het is voor het onderzoek eng belangrijk dat je dit echt serieus doet.

Figuur 6.1 Instructie voor het bestuderen van aantekeningen

Gezamenlijk oude voortgangstoetsen bestuderen. Deze groep studenten kreeg van een tutor de instructie om in kleine groepjes van 4 à 5 studenten gedurende 1 uur oude voortgangstoetsvragen te maken (figuur 6.2). De opdracht 
vond plaats onder supervisie van een tutor welke was geinstrueerd om de diepgang van de discussie te bewaken zonder te lang stil te staan bij details. Als tutor mochten ze kritische vragen stellen of aanvullingen geven op de inhoud van de discussie.

Jullie knijgen gedurende éen uur de tjjd om je gezamenlik woor te bereiden op een voortgangstoets. Probeer in dit uur zoveel mogellik kennis op te frissen. Hienoar hebben jullie de beschikking ower oude woortgangstoetsen. Jullie lutor heeft de beschikking over de antwoordsleutel. Het is de bedoeling dat jullie als groep discussiëren over de antwoorden. Leg eikaar uitieggen waarom je denkt dat een antwoord juist of onjuist is. Wanneer geen van jullie het antwoord zeker weet, discussieer dan met elkaar over waarom het ene antwoord meer aannemelijk is dan het andere.

Figuur 6.2 Instructie voor gezamenlijk bestuderen van oude voortgangstoetsen

Controle interventie. Studenten in de controlegroep ontvingen schriftelijk de instructie zich niet voor te bereiden, waarbij zij op de onderzoeksdag werden uitgenodigd voor een 'interventie'. Deze 'interventie' bestond uit het invullen van een aantal vragenlijsten over studieactiviteiten tijdens zelfstudie en onderwijsgroepsbijeenkomsten.

\section{Controle variabelen}

Ter controle van representatieve toewijzing van studenten aan de verschillende interventies zijn studenten vergeleken op: probleemgestuurd studiegedrag, aantal uren studeren voor de voortgangstoets en toetsresultaten Probleemgestuurd studiegedrag. Voor het in kaart brengen van het probleemgestuurd studiegedrag van studenten is dezelfde vragenlijst gebruikt als in de studie naar studiegedrag binnen probleemgestuurd studiegedrag (hoofastuk 3) en de studie naar de spreiding van studiegedrag over de blokperiode (hoofdstuk 4). De vragenlijst bevat 24 profielschetsen van studiegedrag in de onderwijsgroep en tijdens zelfstudie, die na afname resulteert in een nominale indeling van studenten in één van vier typen probleemgestuurd studiegedrag (diep actief, diep passief, oppervlakkig actief en opperylakkig passief) en een interval waarde op de twee dimensies van probleemgestuurd studiegedrag (aard en activiteit).

Aantal studie-uren voor de voortgangstoets. Het aantal studie-uren voor de voortgangstoets is gebaseerd op de antwoorden wellke studenten hebben gegeven tijdens de studie naar de sturing van studie-activiteiten door de voortgangstoets (zie hoofdstuk 5). 
Voortgangstoetsresultaten. De toetsresultaten betreffen de goed-min-fout scores van studenten welke zij hebben behaald in het studiejaar waarin deze studie plaatsvond (1996-1997). De eerste twee voortgangstoetsen zijn voor de interventie-studie afgenomen, de afname van de derde voortgangstoets vond plaats na de interventie-studie.

\section{Interventie-toets}

De voortgangstoets waarvan tijdens de interventie-studie gebruik is gemaakt, betrof de meest recente toets voorafgaande aan de start van studie van de gekozen populatie (de derde voortgangstoets uit studiejaar 1994-1995). Deze toets werd destijds in de vergelijkbare periode van dat studiejaar afgenomen.

\section{Analyse}

Probleemgestuurd studiegedrag wordt beschreven met behulp van beschrijvende statistiek. Verschillen hierin tussen studenten die wel en niet studeerden op de voorgaande toets worden non-parametrisch met een Chi-kwadraat toets getoetst. Verschillen op de componenten probleemgestuurd studiegedrag en toetsresultaten worden getoetst met een one-way ANOVA. Het effect van de verschillende interventies zal worden geanalyseerd met een ANOVA waarbij alle effecten gelijktijdig worden opgenomen in het model.

\section{Resultaten}

\section{Betrouwbaarheid van de effectparameter}

In afwijking van de reguliere afname van de voortgangstoets heeft binnen de interventie-studie het toetsresultaat geen studieconsequenties. Op basis van de reacties van de deelnemende studenten bestaat de indruk dat studenten zich serieus hebben gehouden aan de voorbereidende opdrachten en ook de toets serieus hebben afgelegd. De tijdsduur die studenten nodig hadden voor het afronden van de toets kwam in sterke mate overeen met die van een reguliere toetsafname. In figuur 6.3 wordt een overzicht gegeven van een aantal relevante toetsgegevens ten behoeve van de inschatting van de betrouwbaarheid van afname van de interventie-toets. In de figuur wordt gegeven: de gemiddelde goed-min-fout score (met tussen haakjes de standaarddeviatie) en de interne consistentie (Cronbach's a) van de tweedejaars 
bij de toetsafname in 1995 en de afname van dezelfde toets als interventieparameter. Verder de goed-min-fout score van de onderzoekspopulatie op de drie toetsen die in studiejaar 1996-1997 zijn afgenomen en de interventietoets, met een onderverdeling tussen wel of niet voorbereiden op de tweede voortgangstoets. De vermelde correlaties zijn de correlaties tussen de meetmomenten, eveneens met onderverdeling tussen wel of niet voorbereiden op de tweede voortgangstoets.

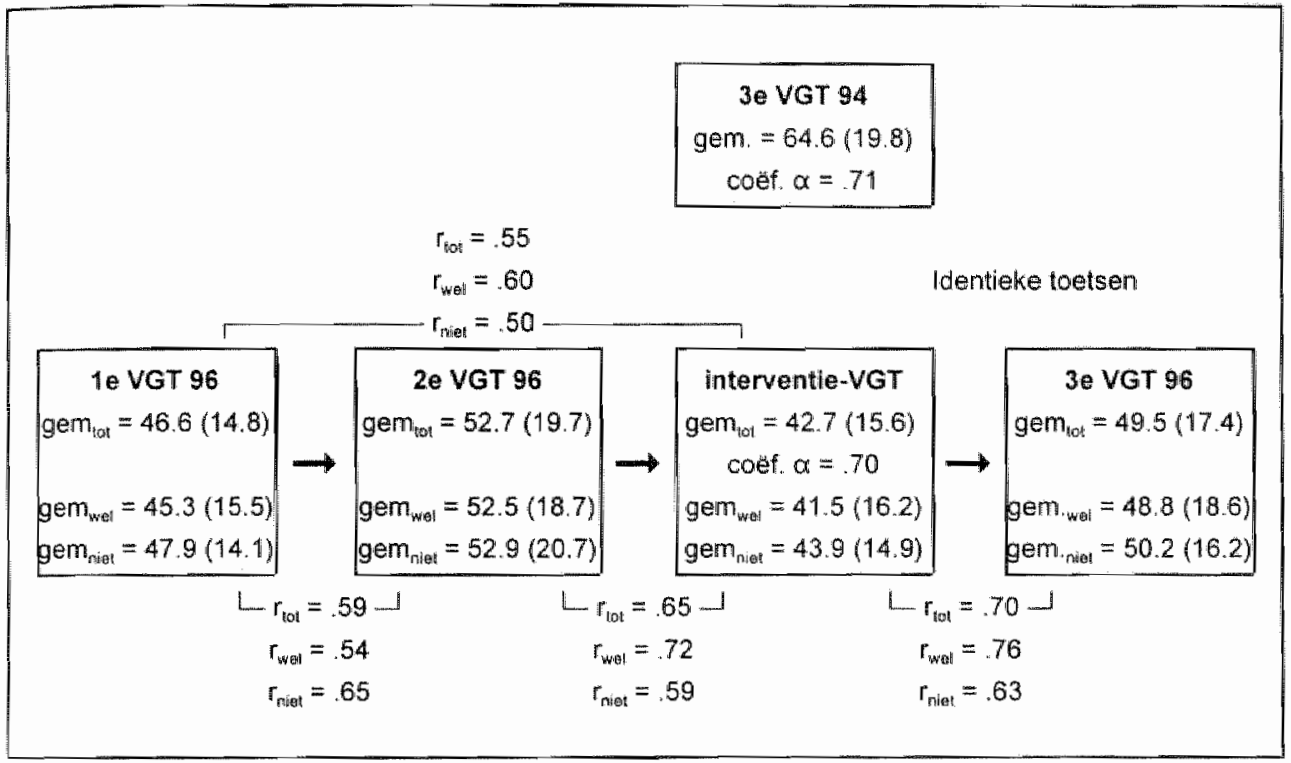

Figuur 6.3 Overzicht van een aantal toetsgegevens ten behoeve van de inschatting van de betrouwbaarheid van de effectparameter

De goed-min-fout score van de tweedejaars van studiejaar 1994-1995 ligt beduidend hoger dan die van de interventie-parameter 1996-1997. De interne consistentie, Cronbach's a is vergelijkbaar. De correlatie tussen toetsmomenten varieert van $r=0.54$ tot $r=0.72$, waarbij de correlaties tussen de eerste en tweede voortgangstoets lager liggen dan de correlaties tussen de tweede voortgangstoets en de interventie-parameter.

\section{Vergelijking studenten die wel en niet studeren voor de voortgangstoets}

In tabel 6.2 en tabel 6.3 wordt weergegeven in hoeverre studenten die zich onderscheiden op basis van wel of niet voorbereiden op de voortgangstoets, zich ook op andere studievariabelen van elkaar onderscheiden. 
Tabel 6.2 Percentage studenten met typen probleemgestuurd studiegedrag voor studenten die wel en niet studeren voor de voortgangstoets

\begin{tabular}{lccc}
\hline & wel studeren $(n=58)$ & & niei studeren $(n=61)$ \\
\cline { 2 - 2 } Type PGO studiegedrag & & & \\
diep actief & $45.9 \%(n=28)$ & & $41.4 \%(n=24)$ \\
oppervlakkig actief & $26.2 \%(n=16)$ & & $32.8 \%(n=19)$ \\
diep passief & $19.7 \%(n=12)$ & & $5.2 \%(n=3)$ \\
oppervlakkig passief & $8.2 \%(n=5)$ & & $20.7 \%(n=12)$ \\
\hline
\end{tabular}

Uit tabel 6.2 blijkt onder studenten die zich voorbereiden een lager percentage met de typering van oppervlakkig actief en oppervlakkig passief probleemgestuurd studiegedrag ten opzichte van studenten die dit niet doen. De verschillen zijn niet significant (Chi-kwadraat $=3.75$, df $=3, p>0.05$ ).

Tabel 6.3 Gemiddelden op de componenten aard en activiteit van probleemgestuurd studiegedrag over studenten die wel en niet studeren

\begin{tabular}{|c|c|c|c|}
\hline & wel studeren & niet studeren & significantie \\
\hline \multicolumn{4}{|c|}{$\begin{array}{l}\text { Componenten vam probleemge- } \\
\text { sturrd studiegedrag }\end{array}$} \\
\hline activiteit & 0.83 & 1.08 & $F(1,120)=0.811 \mathrm{~ns}$ \\
\hline aard & 0.14 & 0.55 & $F(1,120)=3.778 \mathrm{~ns}$ \\
\hline \multicolumn{4}{|l|}{ Eerdere toetsresultaten } \\
\hline eerste VGT 1996 & 45.3 & 47.9 & $F(1,117)=0.869 \mathrm{~ns}$ \\
\hline tweede VGT 1996 & 52.5 & 52.9 & $F(1,121)=0.012 \mathrm{~ns}$ \\
\hline derde VGT 1996 & 48.8 & 50.2 & $F(1,119)=0.213 \mathrm{~ns}$ \\
\hline
\end{tabular}

De waarden voor de dimensies van probleemgestuurd studiegedrag op intervalniveau van de studenten die zich niet voorbereiden op de voortgangstoets zijn hoger dan voor degenen die dit wel doen. Opnieuw zijn de verschillen niet significant. De toetsresultaten van studenten die zich voorbereiden op de toets zin wat lager, waarbij ook hier de verschillen niet significant zijn.

In tabel 6.4 worden de gemiddelden op de eerder vermelde variabelen uitgesplitst naar de drie interventie--condities. 
Tabel 6.4 Gemiddelden op de dimensies activiteit en aard van probleemgestuurd studiegedrag, goed-min-fout scores voorgaande toetsen en gestudeerde uren voor de weede toets over studenten die wel en niet studeren, uitgesplitst naar interventie-conditie

\begin{tabular}{|c|c|c|c|c|c|c|c|c|}
\hline & \multicolumn{3}{|c|}{ wel studeren } & \multirow[b]{2}{*}{$\begin{array}{l}\text { F- } \\
\text { waarde }\end{array}$} & \multicolumn{3}{|c|}{ niet studeren } & \multirow[b]{2}{*}{$\begin{array}{l}\text { F- } \\
\text { waarde }\end{array}$} \\
\hline & $\begin{array}{l}\text { controle } \\
(n=21)\end{array}$ & $\begin{array}{l}\text { aant. } \\
(n=21)\end{array}$ & $\begin{array}{l}\text { VGT-en } \\
(n=20)\end{array}$ & & $\begin{array}{l}\text { controle } \\
(n=20)\end{array}$ & $\begin{array}{c}\text { aant } \\
(n=21)\end{array}$ & $\begin{array}{l}\text { VGT-en } \\
(n=20)\end{array}$ & \\
\hline \multicolumn{9}{|l|}{$\begin{array}{l}\text { Componenten van probleem- } \\
\text { gestuurd studiegedrag }\end{array}$} \\
\hline activiteit & 0.53 & 0.74 & 1.21 & $1.117 \mathrm{~ns}$ & 1.33 & 0.75 & 1.18 & $0.628 \mathrm{~ns}$ \\
\hline aard & -0.02 & 0.37 & 0.04 & $0.694 \mathrm{~ns}$ & 0.67 & 0.37 & 0.62 & $0.348 \mathrm{~ns}$ \\
\hline \multicolumn{9}{|l|}{ Eerdere toetsprestaties } \\
\hline GminF eerste VGT 1996 & 48.6 & 44.3 & 51.1 & $1.219 \mathrm{~ns}$ & 43.1 & 43.4 & 50. 1 & $1.205 \mathrm{~ns}$ \\
\hline GminF tweede VGT 1996 & 53.7 & 51.8 & 53.2 & $0.110 \mathrm{~ns}$ & 52.7 & 53.8 & 51.0 & $0.044 \mathrm{~ns}$ \\
\hline GminF derde VGT 1996 & 49.1 & 51.2 & 45.9 & $0.412 \mathrm{~ns}$ & 50.4 & 48.6 & 51.8 & $0.192 \mathrm{~ns}$ \\
\hline Gestudeerde uren voor $2^{\text {de }}$ VGT & - & $-\cdots$ & $\ldots$ & & 3.0 & 2.4 & 2.7 & $0.214 \mathrm{~ns}$ \\
\hline
\end{tabular}

De tabel laat zien dat binnen de groepen wel of niet voorbereiden voor de voortgangstoets geen significante verschillen worden gevonden tussen de interventie-condities op de dimensies activiteit en aard van probleemgestuurd studiegedrag en aantal uren dat studenten voor de voorgaande toets studeerden (tweede voortgangstoets van studiejaar 1996-1997). Binnen de onderzoekspopulatie wordt ditmaal ook op de toetsresultaten geen significante verschillen gevonden.

\section{Effect van gerichte studie-activiteiten voor de voortgangstoets}

In tabel 6.5 worden de resultaten van de interventie-studie gegeven.

Tabel 6.5 Gemiddelde goed-min-fout score op de interventie-toets over studenten die wel en niet studeren, uitgesplitst naar interventie-conditie (standaard deviatie)

\begin{tabular}{|c|c|c|}
\hline & wel studeren & niet studeren \\
\hline bestuderen van aantekeningen & $41.2(18.7)$ & $43.2(17.4)$ \\
\hline bestuderen van oude VOT-en & $39.8(16.9)$ & $44.0(16.5)$ \\
\hline controle interventie & $43.5(13.1)$ & $44.3(10.8)$ \\
\hline
\end{tabular}

De gemiddelde scores van studenten die voor de voorgaande voortgangstoets niet studeerden zijn opnieuw iets hoger dan die van degenen die dit niet 
deden. Geen van de in de ANOVA getoetste effecten was significant. Geen van de interventies heeft effect $(F(2,122)=0.182, p>0.05)$. Ook blikt er geen onderscheid tussen de studenten die zich wel op de voorgaande voortgangstoets voorbereiden $(F(1,122)=0.676, p>0.05)$. Daarbij zijn er geen interactie verschillen tussen de interventies en toetsvoorbereiding (al of niet) op de voorgaande voortgangstoets $(\mathrm{F}(2,122)=0.115, \mathrm{p}>0.05)$.

\section{Discussie en conclusie}

In deze studie is het effect van gerichte voorbereiding op de voortgangstoets onderzocht. Vooraf is nagegaan in hoeverre studenten die zich wel voorbereiden en studenten die zich niet voorbereiden verschillen in probleemgestuurd studiegedrag en competentie. Er blijken lichte verschillen tussen de studenten die wel en niet studeerden voor de voorafgaande toets op hun probleemgestuurd studiegedrag. De studenten die volstaan met de aaneengeschakelde voorbereiding van de onderwijsgroepen kenmerken zich bovendien door actiever gebruik maken van de onderwijsgroep en zijn meer geneigd tot het toepassen van diepe leeractiviteiten ten opzichte van studenten die zich wel specifiek voorbereiden. De studenten die zich niet specifiek voorbereiden hebben bovendien op de laatste drie voortgangstoetsen jets betere resultaten. Binnen de opzet van de verrichte studie blijken de drie interventies van toetsworbereiding geen effect te hebben. In de drie condities van toetsvoorbereiding worden vergelikbare toetsresultaten behald. Bovendien is er geen verschillend effect voor studenten die zich bij de vorige (reguliere) toetsafname voorbereidden op de toets en degenen die dat niet deden. Dit is overeenkomstig de bedoelingen van de voortgangstoets.

Het onderzoeken van een eventueel effect van wijze van toetsvoorbereiding brengt echter een aantal methodologische beperkingen met zich mee. In dit onderzoek is de lengte van de toetsvoorbereiding standaard gesteld op éen unr. Terwijl in de in hoofdstuk 5 beschreven studie bleek dat de gemiddelde tijdsduur van toetsvoorbereiding (van studenten die zich voorbereidden) drie uur bedraagt. Het kan zijn dat de voorbereidingstijd van éen uur te beperkt is geweest am effectief te zijn, maar bij een langere tijdsduur werd het moeilijk geacht de interventies voldoende te controleren en standaardiseren. 
Een interventie-onderzoek staat of valt met de betrouwbaarheid van de effectparameter. De effectparameter die in het onderzoek is gehanteerd betrof de meest recente voortgangstoets welke niet door de onderzoeksgroep zelf was afgelegd. Vergelijking van de destijds behaalde toetsresultaten en de in het onderzoek behaalde toetsresultaten geeft een vergelikbare (hoge) interne consistentie. Het is hierbij opvallend dat de toetsresultaten tijdens deze studie beduidend lager liggen dan de toetsresultaten van de tweedejaars van destijds. Het verschil in toetsresultaten kan indiceren dat studenten de interventie-toets minder serieus hebben beantwoord dan een reguliere toetsafname. Toch bestond op basis van de reacties van de studenten en de tijdsduur die werd besteed aan het afronden van de toets de indruk dat de toets serieus is afgelegd. Mogelijk sluit de inhoud van de interventie-toets ten gevolge van wijzigingen in het curriculum minder goed aan op de kennis die studenten zich hebben eigen gemaakt. Het is echter zeer onwaarschijnlijk dat minder serieus afronden van de toets selectief plaatsvond bij de studenten uit één van de interventies en daarmee invloed heeft op de conclusie dat geen van de interventies een (afwijkend) effect oplevert.

In de eerder verrichte studies (hoofdstuk 3,4 en 5) ontstond herhaaldelijk de indruk dat er in grotere mate door de iets minder competente studenten voon" de voortgangstoets werd gestudeerd. In het hier verrichte onderzoek worden opnieuw iets betere studieresultaten behaald door studenten die voor de voorgaande toets studeerden, waarbij echter de verschillen zeer marginaal zijn. Hierbij kan een kanttekening worden geplaatst bij de getrokken steekproeven. De random steekproef uit de studenten die voor de voorafgaande toets wel studeerden zijn degenen die op de eerste toets van het studiejaar lagere scores en op de tweede toets van het studiejaar hogere scores behaalden dan degenen die niet werden geselecteerd. De random steekproef uit de studenten die niet voor de voorafgaande toets studeerden zijn daarentegen degenen met lagere scores op de eerste toets van het studiejaar en nagenoeg gelijke scores op de tweede toets van het studiejaar. Hoewel er geen significante verschillen zijn in toetsresultaten tussen de studenten die wel en niet in de steekproeven zijn opgenomen is hiermee het verschil in toetsresultaten van de studenten die wel en niet voor de voorafgaande toets studeerden in de onderzoekspopulatie verkleind. 
Uit deze studie blijkt dat de studenten die niet studeren voor de voortgangstoets de studenten zijn met (op groepsnivean) dieper en actiever probleemgestuurd studiegedrag en bovendien iets betere studieresultaten. Uit deze studie blijkt dat gericht studeren voor de voortgangstoets geen effect heeft. Uitspraken over de oorzaak varu verschillen in studieresultaten tussen studenten die wel en studenten die niet voor de voortgangstoets studeren, als gevolg van verschillend (probleemgestuurd) studiegedrag, verschillende vaardigheden of cognitieve vermogens kunnen op basis van deze studie niet worden gedaan. Wel kan worden geconcludeerd dat er geen compenserend effect uitgaat van niet beoogde specifiek toetsgerichte studie-activiteiten. Sterker nog, deze activiteiten hebben géen effect. Als zodanig past de toets uitstekend binnen de rationalen van probleemgestuurd onderwijs: een actieve studiehouding in de onderwijsgroep wordt beloond en compenserend toetsgerichte studie-activiteiten niet. 


\section{Conclusie, Discussie \& Implicaties}

In deze dissertatie is er vanuit gegaan dat zowel toetsing als onderwijs het studiegedrag van studenten beinvloeden. Wanneer de voortgangstoets aansluit op probleemgestuurd onderwijs zijn de activiteiten die het onderwijs en de woortgangstoets tot gevolg hebben op elkaar afgestemd. In de vijf afzonderlijke studies van deze dissertatie zijn specifieke aspecten van probleemgestuurd onderwijs en de voortgangstoets belicht. De invloed van de onderzochte aspec. ten van voortgangstoetsing of probleemgestuurd onderwijs, te weten 'de uraagteken-optie met goed-min-fout scoring', 'aansturing van studiegedrag volgens de zevensprong', 'regelmatige voorbereiding van de onderwijsgroep' zonder 'toetsgericht studeren' uit te lokken, worden in dit hoofdstuk geintegreerd.

De discussie is opgebouwd volgens het onderzoeksmodel uit hoofdstuk 1. Er wordt getracht een antwoord te geven op de centrale uraag van deze dissertatie: "in hoeverre is er sprake van aansiuting tussen het studiegedrag waartoe de voortgangstoets aanstuurt en het studiegedrag dat met probleemgestuurd onderwijs wordt beoogd?" Bovendien worden de implicaties voor onderwijs, voortgangstoetsing en vervolgonderzoek besproken.

\section{Conclusie en Discussie}

In figuur 7.1 zijn de belangrijkste conclusies ten aanzien van de onderzochte aspecten van voortgangstoetsing of probleemgestuurd onderwijs in het model van figuur 1.2, hoofdstuk 1 geplaatst. De discussie is ingedeeld volgens de verbindingslijnen van het model. 


\section{Probleemgestuurd onderwijs \\ - Meeste sudenten herkennen zich met name in gedragsprofielen specifiek voor probleem gestuurd onderwijs met diepe en/of actieve studie-activiteiten (Hfst. 3) \\ - Studenten bereiden hun ondenwijsgroep regelmatig gespreid voor (Hfst. 4 )}

Invloed probleemgestuurd onderwijs op studiegedrag en studieactiviteiten

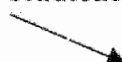

\section{Voortgangstoetsing}

- Studenten maken op grote schaal gebruik wan de vraagtekenoptie (Hist. 2) - De omvang in specifiek studeren woor de toets in aantal studenten is groot (Hist. 3 , 4 \& 5), maar in tjjdsinvestering klein (Hfst. 5)

Invloed voortgangstoetsing op studie gedrag en studie-activiteiten

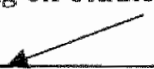

\section{Studiegedrag \& Studie-activiteiten Student}

- Specifiek studeren voor de voortgangstoets vertoont geen duidelijke relatie met type probleemgestuurd studiegedrag en regelmaat van spreiding van studie-activiteiten voor de onderwijsgroep (Hfst. 3 \& 4)

- Specifieke voorbereiding op de loets interiereert nauwelijks met de voorbereiding voor de onderwijsgroep (Hfst. 5)

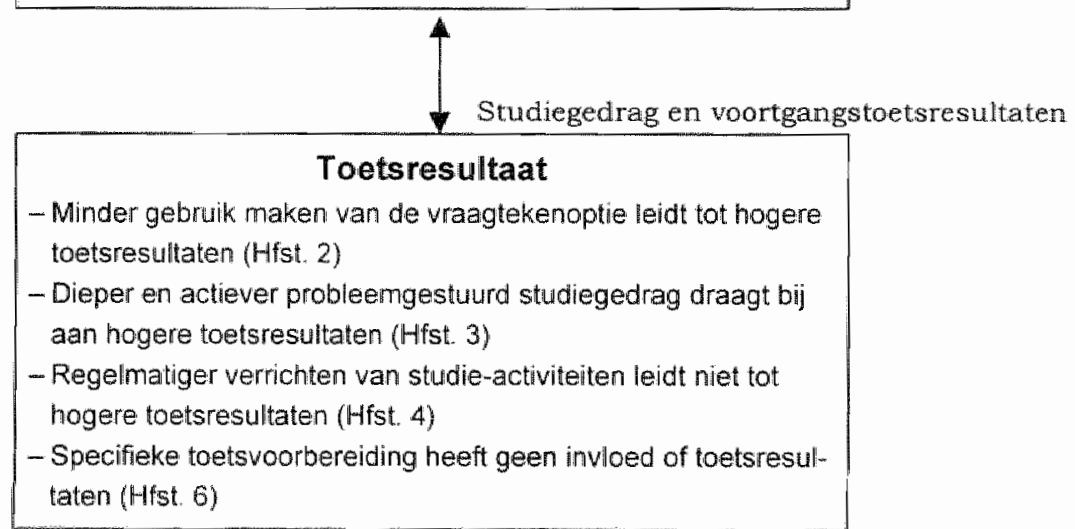

Figuur 7.1 Onderzoeksmodel met de belangrijkste conclusies uit de vijf studies

\section{Invloed probleemgestuurd onderwijs op studiegedrag en studie-activiteiten}

Bij de conclusies over de invloed van probleemgestuurd onderwijs moet worden opgemerkt dat deze dissertatie niet in eerste instantie is gericht op het in kaart brengen van studie-activiteiten die voortkomen uit probleemgestuurd onderwijs. Toch zijn er een aantal punten te benoemen over de studie-activiteiten die voortvloeien uit probleemgestuurd onderwijs op basis van de verrichte studies. In de hoofdstukken 3, 4 en 6 blijkt dat veel studenten hun activiteiten in de onderwijsgroep en tijdens zelfstudie kenmerken als 'actief' en 'diep'. Studenten herkennen zich met name in een actieve opstelling, in de vorm van (mee-) denken over probleemstellingen, alternatieve 
verklaringen en leerdoelen, rapporteren wat is bestudeerd en onduidelijkheden aan elkaar uitleggen (activiteit). In 'hoe' gebruik wordt gemaakt van probleemgestuurd onderwijs herkennen zij zichzelf in een kritische houding, waarin vragen worden gesteld, relaties tussen bevindingen worden gelegd en kritisch wordt nagedacht over datgene wat ze horen en/of bestuderen (aard). De studie-activiteiten die studenten verrichten komen hiermee in belangrijke mate overeen met de studie-activiteiten die binnen probleemgestuurd onderwijs worden beoogd (Moust et al., 1997; Schmidt, 1983).

In de verschillende studies zijn de studie-activiteiten als een geheel van activiteiten tijdens zelfstudie en onderwijsgroep in kaart gebracht, gebaseerd op zelfoordelen. Gezien sommige moeilijk verklaarbare tegenstrijdigheden (studenten die zijn ingedeeld in diep passief studiegedrag scoren hoger op de actief component dan studenten die zijn ingedeeld in oppervlakkig actief studiegedrag) vraagt de vragenlijst om verdere ontwikkeling. Toch lijkt het meten van studie-gedragingen met behulp van gedragsprofielen in elk geval bruikbaar voor het rangschikken en globaal in kaart brengen van studiegedragingen van studenten. Doordat alle studenten alle profielen scoren wordt de relatieve verhouding tot elkaar (in plaats van absolute waarden) duidelijk. De gemaakte keuze voor een meting van studiegedrag als geheel maakt dat specifieke informatie over studiegedragingen in de afzonderlijke fasen van het onderwijsleerproces ontbreken. Dit sluit aan op studies naar leerstijlen en studie-activiteiten tijdens zelfstudie waarin sommige onderzoekers ervoor pleiten aandacht te besteden aan het geheel van activiteiten in onderlinge samenhang en interactie, waarbij affectieve invloeden door de interactie met de situatie worden betrokken (Lonka \& Lindblom-Ylänne, 1996; Meyer, 1991).

De hoeveelheid zelfstudietijd waartoe studenten door het onderwijsaanbod worden gestimuleerd is betrekkelijk laag (gem. 7 uur per week). Dit. blijkt zowel uit de globale tijd-schatting in hoofdstuk 3 , als uit het meer precieze tijdschrijven in hoofdstuk 4 . Het meer precieze tijdschrijven correleert bovendien goed met de globale schattingen uit de programma-evaluatie (hoofdstuk 4). Dit betekent dat globale schattingen goed bruikbaar blijken wanneer de rangorde van studenten in de hoeveelheid zelfstudietijd van belang is. De globale schattingen zijn overigens in absolute zin hoger, hoogstwaarschijnlijk ten gevolge van overschatting, dan het meer precieze tijdschrijven. 
De tijd die word besteedt aan het deelnemen aan onderwijs neemt binnen de onderzochte blokperiode evenveel tijd in beslag als de zelfstudietijd, terwijl binnen probleemgestuurd onderwijs verhoudingsgewijs veel zelfstudie wordt verondersteld. Met deze studielast zal de norm van 1300 uur per jaar, die door Van der Drift en Vos (1987) als haalbaar wordt genoemd, niet worden bereikt. Een lage zelfstudietijd vormt echter pas een probleem wanneer studenten onvoldoende kennis opdoen binnen het (probleemgestuurd) onderwijs. Hoewel bij herhaling wordt verondersteld dat studenten in een probleemgestuurd curriculum over onvoldoende concrete kennis beschikken, worden in Nederland op de voortgangstoets bij vergelijkingen tussen Geneeskunde Faculteiten op de voortgangstoets geen kennisverschillen gevonden (Verwijnen et al., 1987; Van der Vleuten, Verwijnen, Holdrinet, et al., 1996). Bij de Faculteit der Gezondheidswetenschappen kan dit niet op basis van vergelijkingen worden vastgesteld omdat vergelijkbare Faculteiten bij andere universiteiten in Nederland ontbreken. Bovendien theeft de Faculteit der Gezondheidswetenschappen geen duidelijke eindtermen geformuleerd. Bij de implicaties zal hierop worden teruggekomen.

De zelfstudietijd mag dan laag zijn, positief is dat uit hoofdstuk 4 eveneens blijkt dat de studie-inspanning die studenten leveren betrekkelijk regelmatig gespreid plaatsvindt over de gehele onderwijsperiode. Zelfs bij het naderen van de blokgebonden toetsing aan het einde van een onderwijsperiade is de stijging beperkt en wordt er nog steeds ook voor de onderwijsgroepen gestudeerd. Het lijkt er dan ook op dat met het (probleemgestuurd) onderwijs wordt voorkomen dat studenten zoals door Van der Drift en Vos (1987) werd geformuleerd, slechts door het naderen van toetsen tot bepaalde inspanning worden gestimuleerd.

Uit bovenstaande kan worden opgemaakt dat het onderwijs erin geslaagd lijkt studenten op een wenselijke manier te stimuleren. De taken en onderwijsgroepen geven veelal aanleiding tot het soort studie-activiteiten voor de onderwijsgroep en tijdens zelfstudie die overeenkomen met de studie-activiteiten die in probleemgestuurd onderwijs worden beoogd. Bovendien vinden de studie-activiteiten regelmatig plaats met slechts een beperkte verstoring van het studiepatroon als gevolg van toetsing. 


\section{Invloed van voortgangstoetsing op studiegedrag en studie-activiteiten}

Ten aanzien van studie-activiteiten die voortkomen uit voortgangstoetsing hebben de studies de volgende informatie opgeleverd. Studenten maken op grote schaal gebruik van de vraagtekenoptie. Bovendien blijkt uit het hoge percentage vragen waarover studenten rapporteren geen of weinig kennis te hebben, hoe belangrijk het is dat studenten de mogelijkheid krijgen vragen onbeantwoord te laten (van bijna $40 \%$ van de vragen wordt gezegd $0 \%$ zeker te zijn). Positief is dat de huidige scoringsregel nauwelijks leidt tot ongewenst antwoordgedrag in de vorm van blind gokken. Overeenkomstig de bedoeling van goed-min-fout scoring blijkt dat de vragen die worden voorgelegd en waarover studenten (nog) geen kennis hebben nauwelijks worden beantwoord. Hiermee laat de toets studenten de vrijheid tot het maken van individuele studiekeuzes en het leggen van individuele accenten. De vraag is of op deze manier de positief geformuleerde doelstellingen dat studenten zich ook 'gestimuleerd voelen tot het maken van individuele keuzes en het leggen van individuele accenten' en 'studenten het gevael krijgen dat zij (nog) niet alles hoeven te weten' worden bereikt. Een aantal exemplarische opmerkingen van studenten in het intern nieuwsblad van de Faculteit der Gezondheidswetenschappen doen eerder het tegenovergestelde vermoeden: "ik merk niet dat de toets mijn studievoortgang meet", "ik vind de voortgangstoets niet geschikt ... wanneer je bezig bent met een specifiek onderwerp, bijvoorbeeld tijdens een stage", "nuttige controle over een beperkt aantai onderwerpen ..." (Spectrum, 1996). De afname van de voortgangstoets lijkt echter ook geen beperking van vrijheid of beklemming in de vorm van 'ik weet niet genoeg' tot gevolg te hebben. Hoewel in de verschillende studies in deze dissertatie blijkt dat een groot aantal studenten studeert voor de voortgangstoets (meer dan $40 \%$ ), blijkt echter consistent dat de tijd die wordt besteed aan toetsvoorbereiding voor de voortgangstoets beperkt blijft en rond de $1 \frac{1 / 2}{2}$ uur bedraagt. Zowel uit de regelmatige spreiding van studie-activiteiten (in hoofdstuk 4), als uit het lage percentage studenten ( $11 \%$ ) waarbij de toetsgerichte studie-activiteiten ten koste gaan van de onderwijsgroep (hoofdstuk 5), blijkt dat de studieactiviteiten voor de voortgangstoets nauwelijks een verstoring vormen voor de studie-activiteiten voor de onderwijsgroep. Wanneer studenten het gevoel hebben alles voor de toets te moeten weten, zou deze studietijd hoogstwaarschijnlijk hoger zijn. Dit grote aantal studenten dat voor de toets studeert, met echter beperkte tijdsinvestering, wordt telkens bevestigd. De bevinding 
komt terug wanneer hier naar wordt gevraagd: globaal met behulp van gedragsprofielen en globale tijd-schattingen (hoofdstuk 3), met specificaties in tijd besteed aan onderwijs, onderwijsvoorbereiding en toetsvoorbereiding met tijdschrijfdagboeken (hoofdstuk 4), of specificaties in de tijd die wordt besteed aan specifieke toetsvoorbereidende activiteiten (hoofdstuk 5). Het feit dat in de verschillende studies steeds vergelijkbare bevindingen werden gedaan ondanks verschillende steekproeven van studenten uit verschillende jaargroepen, bevestigt deze conclusie. Dit vormt opnieuw een indicatie dat globale tijdschattingen redelijk betrouwbaar zijn.

Voortgangstoetsing blijkt niet geheel overeenkomstig de geformuleerde veronderstellingen toch "te leiclen tot toetsgerichte studie-activiteiten" (Van der Vleuten, Verwijnen \& Wijnen, 1996). Uit de resultaten van de studie in hoofdstuk 5 blijkt echter dat de studie-activiteiten die worden verricht niet de meest ongunstige zijn. Veelal is sprake van activiteiten die gekenmerkt kunnen worden als 'globaal een aantal onderwerpen nakijken' en 'opfrissen'. De in tijdsomvang beperkte inspanning lijkt "de mogelijkheid zich te concentreren op de beoogde studie-activiteiten voor de onderwijsgroep" (Van der Vleuten, Scherpbier, et al., 1996) dan ook niet in de weg te staan.

Opgemerkt moet worden dat deze conclusies worden getrokken binnen een onderwijssetting waarin ook direct gerelateerd aan blokperioden, met een afgebakende kennisdomein, wordt getoetst. Uitgedrukt in studiepunten zijn de bloktoetsen belangrijker dan de voortgangstoetsen, met bloktoetsen zijn er in verhouding meer studiepunten te behalen. Uit de resultaten van de studie in hoofdstuk 4 blijkt dan ook dat er van de bloktoets een sterkere sturing in de richting van toetsgericht studeren uitgaat dan van de voortgangstoets. Desondanks is ook voor de bloktoets de toename in studietijd beperkt en blijven studenten vlak voor een bloktoets zich ook voorbereiden op de onderwijsgroep.

Een betrekkelijk grote groep studenten blijkt de behoefte te voelen toch iets te doen aan toetsgerichte voorbereiding, hoewel zij met het onderwijs worden gestimuleerd tot studie-activiteiten die in het verlengde liggen van de in de onderwijsgroep geformuleerde leerdoelen. Zowel in de studies van hoofdstuk 3 als 4 blijken geen opmerkelijke verschillen in de wijze van toetsvoorbereiding binnen groepen studenten met een bepaald type probleemgestuurd studiegedrag. Er is dus geen sprake van compenserend (ongewenst) toetsgericht studiegedrag van ôf ongewenste studie-activiteiten voor de onderwijs- 
groep (onvoldoende of op onjuiste wijze) of onregelmatige voorbereiding voor de onderwijsgroep. Er lijkt eerder sprake van een algemene drijfveer van studenten, hoogstwaarschijnlijk voortkomend uit de gewoonte dat voor toetsen 'iets moet worden gedaan', zonder dat feitelijk benoemd kan worden welke studenten dit doen. Tot op heden is men er kennelijk niet in geslaagd studenten te overtuigen dat gericht studeren voor de toets geen invloed heeft. Aan de beperkte invloed van de voortgangstoets op studie-activiteiten zit ook een keerzijde. Hoewel dit in deze dissertatie niet direct onderzocht is, kan het grote aantal vragen dat wordt voorgelegd waarover studenten geen kennis bezitten frustrerend werken, leiden tot gebrek aan herkenbaarheid van de eigen kennis en weinig zichtbaar maken van groei in kennis. Het maakt bij het samenstellen van de toets weinig verschil of studenten vragen uit het gehele kennisdomein Gezondheidswetenschappen krijgen voorgelegd (alle drie de stromen, zoals nu het geval is) of slechts de vragen uit de eigen stroom. Psychometrisch heeft dit als consequentie dat de toetslengte van 600 vragen met vragen uit alle afstudeerrichtingen de interne consistentie verhoogt. Men kan zich overigens afvragen wat meer inhoudsvalide is, het kennisdomein van Gezondheidswetenschappen of het kennisdomein van de biologische-, gedrags- ofwel maatschappij-stroom. Wellicht vormt het grote aantal vragen waar studenten geen antwoord op kunnen geven tevens een verklaring voor de beperkte feedbackfunctie voor het opsporen van kennishiaten, zoals uit eerder onderzoek bleek (Van Berkel, 1996; Geerligs, 1993).

\section{Studiegedrag en voortgangstoetsresultaten}

Onder de huidige scoringsregel met goed-min-fout correctie blijkt ongewenst antwoordgedrag in de vorm van gokken te worden voorkomen. Voor de meeste studenten lijkt het echter gunstiger om een groter aantal vragen te beantwoorden. Sterker nog, empirisch blijkt dat ongewenst antwoordgedrag in de vorm van 'alle vragen beantwoorden, ook zonder kennis' wordt beloond in plaats van bestraft, en 'gebruik maken van de vraagtekenoptie' wordt bestraft in plaats van beloond. Uitgaande van de definiëring van Cizek (1993) dat een toets aansluit op het onderwijs wanneer beoogde studie-activiteiten worden beloond en niet beoogde studie-activiteiten worden afgestraft, vormt dit een tekortkoming van de toets. In de paragraaf over de implicaties zal hier op teruggekomen worden. 
Studie-activiteiten waarop wordt aangestuurd met het onderwijs zoals dat in hoofdstuk 3 is gedefinieerd (een actieve deelname aan de zevensprong, kritisch reflecteren, etc.), blijkt bij te dragen aan hogere toetsresultaten. Statistisch gezien komt studiegedrag dat meer conform de doelstellingen van het onderwijs is, tot uiting in de toets in de vorm van een significante verbetering in het voorspellen van hogere toetsresultaten. Een sterk punt van de toets is bovendien dat dit effect wel wordt gewonden bij een toets die zich richt op niet direct aan het gevolgde onderwijs gerelateerde kennis, de voortgangstoets, en niet bij een toets met een afgebakend kennisdomein, de bloktoets. Deze laatste toets wordt afgenomen direct na afloop van een onderwijsperiode en lokt ook in sterkere mate toetsgericht studiegedrag uit. Dit kan een bevestiging vormen dat het doorlopen van de zevensprong leidt tot een beter verloop van kennis opdoen en kennisopbouw of leidt tot een sterker netwerk" (Norman, 1988). Ook kan het betekenen dat de voortgangstoets niet alleen vraagt naar verspreide losse feitenkennis, maar vooral ook naar samengestelde (toepassings-) kennis, zoals geformuleerd werd door Swanson et al (1991). Ondanks alle kritiek op het toetsen van feitenkennis in een probleemgestuurd curriculum maakte Norman (1991) hierover een belangrijke opmerking, namelijk dat in elk beroep ook een hoeveelheid parate kennis noodzakelijk is. De verbetering van toetsresultaten door het verrichten van studie-activiteiten waarop wordt aangestuurd met probleemgestuurd onderwijs is echter klein. Aanpassing van hun studie-activiteiten in de gewenste richting zal voor studenten weinig consequenties hebben in de vorm van een beloning met een zichtbaar betere toetsscore. Ook is niet te verwachten dat voor studenten nog herkenbaar is dat degene met betere resultaten op de voortgangstoets ook degenen zijn die op een positieve manier deelnemen aan probleemgestunurd onderwijs in de onderwijsgroep.

Gewenste studie-activiteiten voor de onderwijsgroepen blijken wel statistisch tot uiting te komen in de toets. De gewenste regelmatige voorbereiding van de onderwijsgroepsbijeenkomsten wordt daarentegen niet zichtbaar in betere studieresultaten. Deze conclusie wordt echter getrokken binnen een onderwijscontext waarin alle studenten tot betreikelijk regelmatige studie-activiteiten worden geprikkeld en kan anders zijn voor onderwijssituaties waarin er meer variatie tussen studenten is qua regelmaat van studie-activiteiten. In probleemgestuurd onderwijs worden studenten dus niet op een directe manier beloond voor regelmatig studiegedrag in toetsresultaten. Misschien is er 
wel sprake van indirecte beloning in de vorm van minder (gevoelsmatige) druk om de toets te moeten halen tijdens de (overigens beperkte) toetswoorbereiding voor zowel de bloktoets als voortgangstoets. Daarnaast is er misschien sprake van een indirect effect via de voorbereiding voor de onderwijsgroepen (bij voorkeur regelmatig) die noodzakelijk is voor een goed functionerende onderwijsgroep, waarbij de activiteiten in de onderwijsgroepen vervolgens leiden tot betere kennis.

Ook specifieke toetsgerichte studie-activiteiten worden niet beloond. Uit het experimentele design van de laatste studie (hoofdstuk 6 ) blijkt dat toetsgericht studiegedrag geen effect heeft. Toetsgerichte activiteiten kumnen dus niet compenserend werken. Daarmee wordt de veronderstelling dat niet voor de voortgangstoets gestudeerd kan worden bevestigd.

Al met al blijkt dat de toepassing van de voortgangstoets als instrument om gewenst studiegedrag te belonen en ongewenst studiegedrag af te straffen beperkt is. Bovendien suggereert de naam van de toets een beloning in de vorm van zichtbaar maken van 'voortgang'. Hoewel toename in toetsscores in de beschreven studies niet expliciet aan de orde is geweest blijkt bij vergelijking tussen toetsresultaten van eerste- tot en met vierdejaars bij de Faculteit der Gezondheidswetenschappen de stijging in scores beperkt (bijvoorbeeld tabel 3.5, tabel 5.5 of tabel 1 in bijlage 1 ). Ook bij de voortgangstoets die in de huisartsenopleiding wordt gebruikt blijkt de sterkste groei in toetsscores plaats te vinden in de eerste acht maanden van de opleiding en wordt een afname in toetsscores waargenomen bij huisartsen 5-10 jaar na het afstuderen (Van Leeuwen, 1995). Criticasters kunnen opmerken dat studenten Gezondheidswetenschappen in de loop van de studie (te) weinig kennis opdoen. Eén van de verklaringen van Van Leeuwen lijkt echter waarschijnlijker. Zij noemt namelijk als verklaring dat slechts een gedeelte van de kennis regelmatig wordt gebruikt en dat de kennis die niet frequent wordt gebruikt (in haar onderzoek over niet veel voorkomende pathologie) minder toegankelijk wordt. De stageperiode aan het einde van de studie Gezondheidswetenschappen kenmerkt zich ook door gebruikmaking van slechts een klein, veelal specifiek gedeelte van het kennisdomein Gezondheidswetenschappen. Een verkllaring voor de beperkte toename in toetsscores moet dan ook worden gezocht in de aansluiting van de inhoud van de toets op de inhoud van het onderwijs. Bij de implicaties zal hierop teruggekomen worden. 


\section{Eindconclusie en implicaties}

De voortgangstoets blijkt een toetsvorm met weinig consequenties voor ongewenst studiegedrag ten koste van studie-activiteiten voor de onderwijsgroep. De directe relatie tussen toetsing en studie-inspanning voor de toets lijkt op een goede manier doorbroken. Bovendien worden in bescheiden mate verschillen in studiegedragingen en kwaliteit van studie-activiteiten zichtbaar gemaakt in de studieresultaten. Daarnaast blijkt empirisch dat specifiek studeren voor de voortgangstoets geen effect heeft. Vanuit dit opzicht is het een toetsvorm met potentieel!

Zorgwekkend, is clat empirisch blijkt dat een zeer groot aantal studenten bij de huidige goed-min-fout scoring door het volgen van het huidige advies 'gebruik wanneer je een antwoord niet weet het vraagteken' zichzelf benadeelt. De studies hebben alle plaatsgevonden bij de faculteit der Gezondheidswetenschappen. Replicatie van dergelijk onderzoek binnen andere opleidingen is belangrijk om het inzicht in de toepasbaarheid van voortgangstoetsing binnen opleidingen en binnen probleemgestuurd onderwijs verder te vergroten. De diversiteit van de verschillende afstudeerrichtingen brengt een aantal specifieke problemen met zich mee, waar op teruggekomen zal worden. Desondanks volgen uit de vijf studies die in deze dissertatie zijn beschreven ook een aantal aanbevelingen die hun waarde hebben voor voortgangstoetsing binnen (probleemgestuurd) onderwijs in het algemeen, over onderwijs en onderzoek.

\section{Het probleemgestuurd onderwijs}

Voor aanvang van de studie zijn studenten gewend aan het idee dat zij kennis opdoen door te studeren voor toetsen. Voortgangstoetsing en probleemgestuurd onderwijs blijkt te vragen om een (cultuur)omslag in denken en handelen. In probleemgestuurd onderwijs doen studenten min of meer 'automatisch' kennis op, door in de onderwijsgroepsbijeenkomsten relevante leerdoelen te formuleren en problemen op te lossen in plaats van een duidelijk omschreven hoeveelheid leerstof te bestuderen voor een toets. Dit vraagt aanpassing in denken en handelen van zowel studenten als docenten.

Studenten moeten tot (regelmatige) studie-inspanning voor de onderwijsgroepsbijeenkomsten worden gestimuleerd. Niet de regelmaat op zichzelf, maar de activiteiten binnen deze regelmaat lijken een bijdrage te leveren aan 
kennisopname. Daarom is expliciete aandacht binnen de studie voor het aanleren en verbeteren van studievaardigheden van studenten bijzonder waardevol. Studievaardigheden moeten daarbij worden beschouwd als de vaardigheden die nodig zijn voor het functioneren binnen een bepaalde onderwijssetting. Voor probleemgestuurd onderwijs betekent dit zowel het toepassen van de zevensprong, de zelfstudie naar aanleiding van de leerdoelen, het samenwerken in en het deelnemen aan een onderwijsgroep. Om deze reden is ook onderzoek naar de invloed van de voorbespreking en de leerdoelen op de zelfstudie belangrijk. Met de ontworpen vragenlijst over probleemgestuurd studiegedrag is in deze dissertatie een (beperkte) invloed op kennisverwerking, van studie-activiteiten die specifiek zijn voor probleemgestuurd onderwijs gebleken. Het illustreert het belang van specifieker onderzoek naar de wijze waarop studenten aan de slag gaan (het proces) met leerdoelen, bijvoorbeeld de manier waarop zelfstudie-activiteiten worden teruggekoppeld in de rapportagefase en de rol van feedback van medestudenten.

Daarnaast kan gericht onderzoek naar aspecten die een rol spelen bij kennisopbouw in het doorlopen van de zevensprong, de groepsdeelname of het groepsproces, bijdragen aan de ontwikkeling van onderwijs. Specifiek vervolgonderzoek waarin zoveel mogelijk wordt aangesloten op de concrete onderwijssituatie, naar zowel de rol van afzonderlijke aspecten als van de onderlinge interactie van onderdelen van de zevensprong en de invloed van affectieve processen is gewenst. Bijvoorbeeld met behulp van studies waarin vergelijkingen worden gemaakt tussen verschillende groepen binnen blokperioden en waarin wordt gevarieerd met toepassingen van de zevensprong, etc. De onderzoeken moeten gepaard gaan met evaluatie van leereffecten en de invloed van (aansluitende) toetsing op deze leeractiviteiten, gericht op zowel proces als productevaluatie.

In verder onderzoek met de vragenlijst over probleemgestuurd studiegedrag vraagt deze om verdere ontwikkeling van de inhoud van de profielen, waarbij onderzocht moet worden of er sprake is van een evenwichtige vertegenwoordiging van gedragingen die typerend zijn voor wat studenten doen en hoe studenten dit doen. Ook de veronderstelling dat het gebruik van gedragsprofielen binnen de situatie van het leerproces (de zevensprong) sociaal wenselijk antwoorden beperkt, vraagt om verder onderzoek. Evenals nader onderzoek naar de mate van overeenstemming tussen zelfoordelen en oordelen van 
medestudenten en/of tutoren het inzicht in de bruikbaarheid van zelfoordelen en gedragsprofielen vergroot.

Docenten lijken er redelijk in geslaagd de stimulans tot studie-activiteiten door toetsing niet ten koste te laten gaan van studie-activiteiten voor de onderwijsgroep. Het is belangrijk dat docenten en tutoren een spil blijven vormen in het motiveren en stimuleren van studenten tot betekenis gerichte studie-activiteiten. Vanuit hun rol en functie kunnen zij de onderwijsgroepsbijeenkomsten verdiepen en een belangrijke voorbeeldfunctie vervullen. Om docenten te scholen en begeleiden in deze taak is een belangrijk rol weggelegd voor docentenprofessionalisering. In onderwijs blijft aandacht voor het ontwerpen van motiverende en stimulerende taken namelijk noodzakelijk. De toepassing van en leren omgaan met nieuwe media-technieken, zoals bijvoorbeeld internet en afstandsonderwijs via de computer, vragen daarbij een plaats in het onderwijs. Bij het gebruik van dergelijke middelen moet echter telkens voor ogen worden gehouden met welk doel voor deze middelen wordt gekozen en tot welke studie-activiteiten studenten met deze middelen worden geactiveerd. Wellicht kan het ontwerpen van meer motiverend onderwijs of de toepassing van nieuwe middelen een rol spelen in het verhogen van de lage zelfstudietijd die in deze dissertatie werd gevonden (hoofdstuk 4).

Het is niet verstandig om zonder meer over te gaan tot allerlei maatregelen in de vorm van meer verplichtingen, meer toetsen, meer onderwijs, etc. om de zelfstudietijd te verhogen. Richtinggevend bij de maatregelen moeten de inhoudelijke doelstellingen van het onderwijs zijn over vereiste kennis en vaardigheden van de afgestudeerden. In het toetsen van deze kennis en vaardigheden moet natuurlijk worden gezocht naar geëigende en aansluitende toetsvormen.

In het perspectief van de lage zelfstudietijd is een belangrijke vraag of de afgestudeerden beschikken over voldoende kennis en vaardigheden om functies te vervullen op het niveau waarvoor ze zijn opgeleid. Daarnaast is een belangrijke vraag of zij beschikken over meer, dezelfde of minder kennis en vaardigheden dan afgestudeerden uit een traditioneel curriculum. Dit vraagt om onderzoek naar de beschikking over (voldoende) academische vaardigheden en de voorbereiding op de arbeidsmarkt. Over de betrouwbaarheid en validiteit van instrumenten die inzicht geven in de beheersing van vaardigheden waarop met probleemgestuurd onderwijs wordt aangestuurd, zoals het vermogen van studenten problemen op te lossen, kenmis up-to-date 
te houden, zelf sturing te geven aan hun leerproces, etc. bestaat nog veel onduidelikheid (Thomas, 1997). In twee studies in Nederland naar het probleemoplossend vermogen van studenten, zijn vergelijkingen gemaakt tussen probleemgestuurde, geintegreerde en traditionele curricula van geneeskunde faculteiten (Schmidt et al, 1996; Schuwirth, submitted). Met instrumenten waarin probleemoplossend vermogen wordt getoetst blijkt men in staat curriculum verschillen aan te tonen: in reactie op geschreven casus hardop denkend (correcte) medische diagnoses stellen (Schmidt et al.) of het nemen van correcte medische beslissingen met behulp van gecomputeriseerde casusgerichte toetsing (Schuwirth et al.). Schmidt et al. noemt de integratie tussen basisvakken en klinische vakken als verklaring voor een positief effect dat met name (of pas) zichtbaar wordt tijdens de co-schappen. Schuwirth et al. neigt ernaar het effect toe te schrijven aan andere onderdelen in het curricullum, namelijk het vaardigheidsonderwijs in het skillslab. In beide studies is men het erover eens dat verder onderzoek is vereist. De verdere ontwikkeling van instrumenten zou zich bij voorkeur, naast gebruik voor onderzoek naar de effecten van het onderwijs, ook moeten richten op de toepasbaarheid binnen de verschillende onderwijssettings, zoals: de aansluiting op het in kaart brengen van de beheersing van kennis en vaardigheden die met het onderwijs worden beoogd, de mogelijkheid tot aanwending van de instrumenten als positieve stimulans tot gewenste studie-activiteiten en de feedback-waarde naar studenten omtrent de mate van beheersing.

\section{De voortgangstoets}

Voortgangstoetsing vraagt andere 'toetsvoorbereiding' en 'antwoordgedrag" wan studenten, waar zij veelal niet eerder mee in aanraking zijn gekomen. Deze dissertatie illustreert dat de studenten (nog) niet volledig vertrouwen op 'automatisch' kennis opdoen door onderwijsgroepen regelmatig voor te bereiden, maar (nog) 'terugvallen' op kennis opdoen door te studeren voor toetsen. Het zoeken naar mogelijkheden om op het punt van 'toetsvoorbereiding' bij studenten (studeer-)gedragverandering te bewerkstelligen lijkt gewenst. In de vorm van gerichte en systematische voorlichting zou het met enige creativiteit en inventiviteit moeten lukken studenten te overtuigen dat reguliere woorbereidingen van onderwijsgroepen de gewenste vorm van voorbereiding zijn en er niet specifiek voor de voortgangstoets hoeft te worden gestudeerd. 
Het verdient aanbeveling studenten zorgvuldiger te informeren over hun optimale antwoordgedrag: meer vragen beantwoorden. Ook al betekent het in dit geval een antwoordadvies dat tegengesteld is aan de oorspronkelijke wensen. Het is echter moeilijk verdedigbaar studenten informatie over de meest optimale antwoordstrategie te onthouden. Er zou gezocht moeten worden naar een alternatief woor de gehanteerde scoringsregel die èn gokken ontmoedigt ền aansluit op het meest gewenste antwoordgedrag. Hierbij moet de vrijheid voor studenten om niet alles (al) te hoeven weten wel intact worden gelaten. Op dit laatste zal worden teruggekomen in de slot-paragraaf van dit hoofdstuk.

Inzicht geven in kennishiaten vraagt duidelijkheid en herkenbaarheid van het einddoel van de studie. Gebruik van de voortgangstoets hiervoor vraagt om duidelijk omschreven eindtermen van de studie met een daarop afgestemde inhoud van de voortgangstoets. Concreet voor de Faculteit der Gezondheidswetenschappen is het goed voorstelbaar dat de eindtermen van bijvoorbeeld een afstudeerrichting Biologische Gezondheidskunde niet in én en dezelfde toets verenigbaar zijn met die van Gezondheidsvoorlichting. De wijze waarop bij de Faculteit der Gezondheidswetenschappen sinds studie jaar 1995-1996 de voortgangstoets wordt samengesteld brengt mogelijk een gevaar voor (ongewenste) studie-activiteiten met zich mee. De aanlevering van vragen door blokcoördinatoren over de inhoud van onderwijsperioden die in het lopende studiejaar binnen het curriculum worden aangeboden werkt mogelijk toetsgerichte studie-activiteiten in de vorm van bestudering van de werwachte inhoud van de toets met zich mee. Mogelijk dragen wijzigingen in. antwoord-instructie, scoringsregel en toetsinhoud ertoe bij dat kennisgroei als gevolg van voortgang in de studie beter wordt waargenomen.

Op welke manier één van de initiële doelstellingen van de voortgangstoets kan worden bereikt om studenten door feedback te stimuleren tot het wegwerken van kennishiaten, lijkt een punt dat aandacht behoeft. Ontwikkeling van instrumenten met moderne grafische figuren, bijvoorbeeld opvraagbaar via een persoonlijk account op internet die aanschouwelijk inzicht geven in het kennisniveau en de kennishiaten van studenten, lijken gewenst. Dit geeft studenten concreet in handen in welke richting zij zelf sturing kunnen geven of hebben gegeven aan het eigen leerproces.

Tevens zou gezocht moeten worden naar concrete middelen of maatregelen om studenten te stimuleren èn belonen tot daadwerkelijk aan de slag gaan 
met de feedback. In de slotparagraaf van dit hoofdstuk zal hierop in worden gegaan. Vanzelfsprekend vraagt dit om continue evaluatie die nagaat of de studie-activiteiten die met het onderwijs wordt beoogd leiden tot datgene waartoe studenten worden gestimuleerd.

Hoewel in deze dissertatie sterk de nadruk is gelegd op de invloed van toetsing op studie-activiteiten moet binnen de onderwijspraktijk het belang van de kwaliteit van de toets en de toetsvragen zeker niet uit het oog worden verloren. Een voortgangstoets kan studenten inzicht geven in hun kennisniveau en kan docenten een bron van informatie opleveren over het effect van hun onderwijs. De voortgangstoets moet dan een goede afspiegeling vormen van de eindtermen van een curriculum. Dit vraagt echter om inhoudelijke, vormtechnische en psychometrische controle. Veranderingen in de kwaliteitsbewaking van de voortgangstoets zullen niet alleen consequenties hebben voor de kwaliteit van de toetsvragen en de inhoud(svaliditeit) van de toets, maar ook woor de feedback-waarde naar studenten en docenten. Men zal alert moeten zijn op (directe) kwaliteitsveranderingen en (indirecte) studie-gedragsveranderingen bij studenten. Wijnen (1993) benadrukt dat het noodzakelijk blijkt "docenten eraan te herinneren dat voortgangstoetsen en vakgebonden toetsen andere vragen veronderstellen, omdat de toetsbare kennis in beide gevallen verschillend is'. De wijzigingen bij de Faculteit der Gezondheidswetenschappen, waar vragen met ingang van studiejaar 1995 1996 worden aangeleverd door blokcoördinatoren, lijkt het extra belangrijk dit onderscheid goed te waarborgen.

Wanneer het potentieel van een voortgangstoets binnen probleemgestuurd onderwijs belangrijk wordt gevonden, zullen hier consequenties aan moeten worden verbonden in de vorm van beschikbaar stellen van tijd en middelen.

\section{En dan ... ?}

Het moge duidelijk zijn dat in de discussies bij verschillende studierichtingen, waaronder de Faculteit der Gezondheidswetenschappen, over het wel of niet voortzetten van de voortgangstoets of het wel of niet starten met een voortgangstoets niet eenzijdig de argumenten op basis van psychometrische getallen of eenzijdig onderwijskundige argumenten de overhand mogen krijgen. Deze argumenten zouden gecombineerd moeten worden om "met de inrichting van het onderwijs en de daaraan gekoppelde toetsing te streven naar een zo hoog mogelijk niveau van gewenste studie-activiteiten, inclusief 
toenemende aandacht voor wat moet worden getoetst, in de richting van de ontwikkeling van toetsstrategieën die gevoeliger indicatoren zijn van het resultaat van deze studie-activiteiten" (Cizek, pagina 9, 1993). Momenteel blijkt de voortgangstoets niet te leiden tot voor het onderwijs ongunstige studie-activiteiter.

Het sterke van de voortgangstoets, dat deze niet leidt tot ongewenste sturing wan studie-activiteiten, lijkt tevens ook de zwakte vanwege de beperkte aanwending wan 'de kracht van het toepassen van het beloningsprincipe' (Cizek, 1993 ) of het 'gebruiken van het sturend effect van toetsing voor het implementeren van bepaalde onderwijspolitiek' (Linn, 1993).

Wellicht is een manier te bedenken waarop de voortgangstoets tevens bijdraagt aan het bewerkstelligen van gunstige studie-activiteiten, aanvullend aan probleemgestuurd onclerwijs. Op basis van deze dissertatie is een aantal aangrijpingspunten te noemen. De huidige scoringsregel, al of niet in combinatie met de hantering van de vraagtekenoptie, zou aangepast kunnen worden. Het is niet eenvoudig een scoringsmethode te ontwikkelen die geen bias introduceert, waarbij de meest optimale antwoordstrategie voor studenten inzichtelijk is en studenten zonder consequenties vragen onbeantwoord kunnen laten. Wanneer een summatieve waarde wordt toegekend aan de wijze waarop studenten gebleken kennishiaten wegwerken in plaats van een summatieve waarde aan de toetsscore, krijgt de voortgangstoets een totaal andere rol. Gedacht kan worden in de richting van bijvoorbeeld een portfolio's waarin studenten met specifieke studie-activiteiten aantonen op welke manier zij gebleken kennishiaten hebben weggewerkt. Hierbij moet voorkomen worden dat eenzijdig wordt gekeken naar (eerst-) volgende toetsresultaten (het product) op specifieke categorieën, op die manier zouden verkapte deeltoetsen ontstaan. Nadruk op het proces, op hoe studenten hun kennishiaten wegwerken, sluit sterker aan op de doelstelling van zelfgestuurd leren in probleemgestuurd onderwijs. Dit heeft overigens wel consequenties voor de toets: de toets moet voldoende specifiek zijn om kennishiaten aan het licht te brengen, de toets moet een goede weerspiegeling zijn van het kennisdomein van een studierichting waarin een student afstudeert, en de toets moet een reële inschatting geven van het relatieve kennisniveau van een student ten opzicht van medestudenten die in een vergelijkbare stadium van de studie zitten. 
Een dergelijke toepassing van de voortgangstoets lijkt niet alleen aan te sluiten op, maar bovendien bij te dragen aan, de belangrijke rol die aan studenten wordt gegeven in het zelfsturing geven aan hun leerproces, en zou daarmee volgens Linn (1993) toepasbaar zijn voor de specifieke bedoelingen van de onderwijssetting. Bovendien vormt een dergelijke gebruik van de voortgangstoets een antwoord op Norman's (1991) uitdaging 'om na te denken over hoe studenten te helpen bij het evalueren van hun leren inzicht geeft in wat zij nog moeten leren'. Dergelijke aanpassingen in het toetsingsstelsel vragen opnieuw uitgebreide evaluatie van de onderwijskundige implicaties.

Hopelijk voelen de voorstanders van cijfermatige argumenten en de voorstanders van onderwijskundige argumenten zich beide voor de toekomst uitgedaagd om samen hun creativiteit aan te wenden om "de sturende werking van de woortgangstoets in positieve zin uit te buiten om te bewerkstelligen dat studenten de gewenste studie-activiteiten verrichten" (Van der Vleuten, 1.996).

Kortom: in de te maken keuzen, al of niet in de aanpassing van de voortgangstoets moet de aansluiting van de toetsvormen op de doelstellingen van het onderwijs leidraad vormen. Dit vraagt om afstemming tussen een groot aantal aspecten. Allereerst tussen de kennis en vaardigheden die in het onderwijs worden gevraagd en degene die worden getoetst. Bovendien afstemming tussen de studie-activiteiten die met het onderwijs worden geactiveerde en degene die door toetsvormen worden geactiveerd. Daarnaast moet de gevraagde tijdsinspanning voor bepaalde studie-activiteiten en verschillende toetswormen overeenkomen met het belang dat hieraan wordt gehecht in de studie. 



\section{Samenvatting}

In onderwijs heeft toetsing een sterke sturende invloed op de studie-activiteiten van studenten. Dit heeft tot gevolg dat de doelstellingen van het onderwijs worden ondermijnd wanneer het toetssysteem of kenmerken wan het toetssysteem niet aansluiten op de onderwijsvorm. Centraal in deze dissertatie staat de vraag in hoeverre er sprake is van aansluiting tussen het studiegedrag dat de voortgangstoets aanstuurt en het studiegedrag dat met probleemgestuurd onderwijs wordt beoogd. In vijf afzonderlijke studies zijn specifieke aspecten onderzocht die gezamenlijk het studiegedrag van studenten beïnvloeden. De aspecten hebben betrekking op kenmerken van probleemgestuurd onderwijs of de voortgangstoets. De onderzochte aspecten "de vraagteken-optie met goed-min-fout scoring, 'aansturing van studiegedrag volgens de zevensprong', 'regelmatige voorbereiding van de onderwijsgroep' zonder 'toetsgericht studeren' hebben elk een bepaalde invloed op het studiegedrag van studenten. De congruentie tussen het studiegedrag van de student waar met het onderwijs op aangestuurd wordt en het studiegeclrag waar voortgangstoetsing aanleiding toe geeft, bepaalt de aansluiting van de voortgangstoets op probleemgestuurd onderwijs. Elk van de vijf studies is in een afzonderlijk hoofdstuk beschreven.

In het eerste hoofdstuk is een inleiding gegeven op de vijf verrichte studies. Het belang van aandacht voor de onderwijskundige implicaties van toetsing is toegelicht. Vanuit de visie dat elke onderwijs-context vraagt om een afgestemde vorm van toetsing is uitleg gegeven over probleemgestuurd onderwijs en de voortgangstoets.

In probleemgestuurd onderwijs hebben studenten in principe een centrale rol in het sturen van de eigen studie-activiteiten om zich kennis en vaardigheden eigen te maken. In kleine groepen worden problemen besproken van waaruit eigen leerdoelen worden geformuleerd. In plaats van een docent die bepaalt welke leerstof studenten moeten gaan bestuderen, vormen deze eigen leerdoelen het uitgangspunt voor zelfstudie. De bevindingen van de zelfstudie worden in een volgende bespreking aan elkaar gerapporteerd, onder supervisie van een tutor. In onderwijsperioden van zes weken (blokken)vindt twee maal per week een onderwijsgroepsbijeenkomst plaats. In elke bijeenkomst 
wordt één probleem (taak) voorbesproken en één probleem (taak) nabesproken. Van de leerdoelen die in de voorbespreking worden geformuleerd worden in de volgende bijeenkomst tijdens de nabespreking de antwoorden aan elkaar gerapporteerd. Op deze manier doen studenten min of meer 'automatisch' kennis op.

De studie-activiteiten waartoe studenten in het onderwijs worden gestimuleerd leiden tot kennis die zij bij voorkeur zich ook over een langere periode nog kunnen herinneren, om uiteindelijk aan het einde van de studie over voldoende kennis en vaardigheden te beschikken. Deze kennis moet worden getoetst. Het is de bedoeling dat de studie-activiteiten waartoe studenten met toetsing worden gestimuleerd overeenstemmen met studie-activiteiten waartoe zij in de onderwijsgroepen worden gestimuleerd.

De voortgangstoets is een kennistoets die vragen bevat over het gehele kennisdomein van een studie. Hierdoor is de inhoud van de toets en het moment van toetsafname niet direct gerelateerd aan het onderwijs dat door studenten wordt gevolgd. Een vergelijkbare toets (met nieuwe toetswragen) wordt een aantal malen per jaar afgenomen bij alle studenten van de betreffende studie, ongeacht afstudeerrichting of vordering in de studie. Met behulp van een groot aantal juist/?/onjuist vragen wordt het gehele kennisdomein van de studie bestreken. De toets veronderstelt studenten de vrijheid te laten eigen leerroutes te kiezen, alle studie-activiteiten te belonen, geen aanleiding te geven voor toetsgericht studiegedrag en geen invloed te hebben op reguliere studie-activiteiten (voor de onderwijsgroep) van studenten. Bovendien wordt verondersteld dat specifiek studeren voor de toets slechts een beperkt nut heeft. Als zodanig zou de toets aansluiten op een probleemgestuurd curriculum. De veronderstellingen hebben de basis gevormd voor deze dissertatie. Aan het einde van het eerste hoofdstuk zijn de afzonderlijke onderzoeksvragen die voortkomend uit de veronderstellingen, van de verschillende studies geformuleerd.

In het tweede hoofdstuk is een studie beschreven waarin is onderzocht in welke omvang gebruik wordt gemaakt van de vraagtekenoptie en hoe zeker studenten zijn van vragen die zij tijdens de toets beantwoorden. Tevens is onderzocht of er bij het gebruik maken wan de vraagtekenoptie selectieve studentengroepen in het voordeel zijn bij goed-min-fout scoring. De resultaten van deze studie zijn gebaseerd op een reguliere voortgangstoets onder 
normale toetscondities, aansluitend gevolgd door 'experimentele' voortgangstoets welke is afgenomen onder afwijkende toetscondities. De experimentele voortgangstoets betrof een selectie van vragen uit de eerder afgelegde voortgangstoets, waarbij de vraagtekenoptie ontbrak. Daarnaast is door studenten een schatting gegeven hoe zeker zij waren over de gegeven antwoorden.

Uit deze studie is gebleken dat studenten over een groot deel van de vragen geen kennis beschikken, zelfs niet aan het einde van de studie. Door de aanwezigheid van de antwoordmogelijkheid "vraagteken' blijft het aantal vragen dat tijdens de reguliere voortgangstoets wordt beantwoord op basis van puur gokken zeer beperkt. Bij het beantwoorden van vragen die in eerste instantie met een vraagteken zijn beantwoord, blijkt een hoger percentage vragen goed dan fout te worden beantwoord. Het hogere percentage goed is niet gelijk voor alle studenten en introduceert verschillen tussen hen. Deze werschillen blijken niet gerelateerd aan de mate waarin studenten tijdens de voortgangstoets risico's nemen. Ook zijn er geen aanwijzingen, zoals op basis van onderzoek elders werd gesuggereerd dat vooral de studenten met minder kennis worden benadeeld door goed-min-fout scoring ten opzichte van de anderen. De conclusies wijzen in de richting van (iets sterkere) benadeling van de studenten die volgens de huidige scoringsregel de meeste kennis hebben. Bovendien treedt tussen studenten verschil op in wat zij naar hun beleving ervaren als gokken en als weten. Maar ook hier indiceren de conclusies een sterkere benadeling van de studenten met de meeste kennis ten opzichte van studenten met de minste kennis.

Het gebruik van de vraagteken-optie laat aan de ene kant studenten de wrijheid eigen leerdoelen te bepalen, zonder dat het niet bestuderen van bepaalde onderwerpen directe consequenties heeft bij toetsing maar introduceert aan de andere kant bepaalde bias. De benadeling geldt echter in ster * kere mate voor de studenten die een voldoende halen dan voor studenten die ten aanzien van hun beoordeling aan de onderkant zitten.

Onder de huidige antwoordinstructie wordt de meest gunstige antwoordstrategie onvoldoende benadrukt. Geconcludeerd kan worden dat deze antwoordinstructie tenminste aangescherpt moet worden, en bovendien de gehanteerde scoringsregel heroverwogen moet worden.

In het derde hoofastuk is een studie beschreven waarin studenten op basis van hun studiegedrag en studie-activiteiten zijn onderscheiden in typen 
probleemgestuurd studiegedrag. Onderzocht is of verschillen in de mate waarin studenten zich in hun studie-activiteiten laten sturen door probleemgestuurd onderwijs leidt tot variatie in wel of niet gaan studeren voor de voortgangstoets. Bovendien is nagegaan of studiegedrag dat sterker overeenkomt met de gedachte achter probleemgestuurd onderwijs wordt beloond met betere voortgangstoetsresultaten. De resultaten van deze studie zijn gebaseerd op een vragenlijst met gedragsprofielen en zelfbeoordelingen.

In de vragenlijst, die gericht is op studie-activiteiten tijdens de onderwijsgroep en de zelfstudie specifiek voortkomend uit probleemgestuurd onderwijs, is uitgegaan van twee componenten van probleemgestuurd studiegedrag. Er is onderscheid gemaakt tussen wat studenten doen (benoemd als 'aard' van probleemgestuurd studiegedrag) en hoe zij dit doen (benoemd als 'activiteit' van probleemgestuurd studiegedrag) aan studie-activiteiten die specifiek zijn voor probleemgestuurd onderwijs. Elk van de componenten heeft een wenselijke en een minder wenselijke dimensie; 'oppervlakkig versus diep' en 'passief versus actief'. De combinatie van deze dimensies maakt dat vier typen studenten probleemgestuurd studiegedrag mogelijk zijn: diep actief, diep passief, oppervlakkig actief en oppervlakkig passief.

De meeste studenten herkennen zich in diep actief probleemgestuurd studiegedrag of in oppervlakkig actief studiegedrag. Er lijkt nauwelijks een samenhang tussen het type probleemgestuurd studiegedrag en de wijze waarop deze typen studenten zich specifiek voorbereiden op de voortgangstoets.

Het lijkt dat bij een betrekkelijk grote groep studenten de voortgangstoets aanleiding geeft tot toetsgerichte activiteiten (hoewel zeer robuust gemeten).

Ten aanzien van de beloning van studie-activiteiten lijkt het dat ongewenste studie-activiteiten een geringe, maar geen significante verbetering van voortgangstoetsresultaten met zich mee te brengen. Gewenst probleemgestuurd studiegedrag gemeten met behulp van de gedragsprofielen blijkt een positieve en significante bijdrage te leveren aan voortgangstoetsresultaten.

In het vierde hoofdstuk is een studie beschreven waarin is nagegaan in hoeverre het probleemgestuurd onderwijs aanleiding geeft tot regelmatige spreiding van studie-activiteiten binnen een blokperiode. Tevens is nagegaan in hoeverre het regelmatiger voorbereiden van de onderwijsgroepsbijeenkomsten is gerelateerd aan toetsresultaten. In deze studie hebben studenten 
gedurende acht weken geregistreerd hoeveel tijd zij besteedden an verschilende onderwijsactiviteiten.

Op basis van deze studie blijkt dat studenten hun studie-activiteiten betrekkelijk regelmatig gespreid over een blokperiode verrichten. Naast reguliere onderwijsactiviteiten besteden studenten ook tijd aan specifiek studeren voor toetsen. Hierbij blijkt dat de bloktoets een sterkere verstoring oplevert voor het regelmatig spreiden van studie-activiteiten, ten koste van studie-activiteiten voor de onderwijsgroep, dan de voortgangstoets. Een betere spreiding van studie-activiteiten is echter niet direct terug te zien in betere studieresultaten. Daarentegen hebben probleemgestuurde studie-actiwiteiten opnieuw wel een positieve invloed op de studieresultaten. Ook hierbij is dit effect sterker zichtbaar bij de voortgangstoets dan bij de bloktoets. De bevinding van een invloed van probleemgestuurde studie-activiteiten op voortgangstoetsresultaten terwijl deze invloed ontbreekt bij bloktoetsresultaten vormt een aanwijzing dat met de voortgangstoets daadwerkelijk een ander soort kennis wordt gemeten. Het verschillende kennisdomein van de verschillende toetsen, het afgebakende toetsdomein van de bloktoets ten opzichte van het brede toetsdomein van de voortgangstoets, spelen hierbij mogelijk een nol. De bevindingen in dit onderzoek wersterken de veronderstelling dat de verstorende werking van de woortgangstoets op studie-activiteiten slechts van beperkte omvang is.

In het vijfle hoofdstuk is een studie beschreven waarin nader is onderzocht welke specifieke studie-activiteiten studenten ondernemen voor de voortgangstoets en hoeveel thjd zij heraan besteden. Met behulp van een vagenlijst is tevens nagegaan welke opwattingen er bestaan onder studenten dic niet voor de voortgangstoets studeren. Enkele vragen over hun redenen om niet te studeren en de verwachte effecten van verschillende studie-activiteiten ter voorbereiding op de voortgangstoets maakten onderdeel uit van de ragenlijst voor studenten die niet studeerden.

Een betrekkelijk hoog percentage studenten bereidt zich in bepaalde mate gericht voor op de voortgangstoets. De omvang van deze activiteiten in tijdsinvestering is echter beperkt tot gemiddeld anderhalf uur (drie uur, exclusief degenen die niet studeren), waarbij het soort activiteiten relatief positief is. De meest verrichte activiteiten zijn het doonemen wan oude voortgangstoetsen, het doomemen van oude aantekeningen en het globaal doornemen 
van teksten. De activiteiten kunnen wooral gekenmerkt worden als gericht op het opfrissen van kennis. Bovendien is er slechts een beperkt percentage studenten dat aangeeft dat de studie-activiteiten voor de voortgangstoets ten koste gaat van studie-activiteiten voor de onderwijsgroep. De resultaten in dit onderzoek leveren geen eenduidige aanwijzingen ower het wel of niet ontbreken van een positief effect van gerichte studie-activiteiten op voortgangstoetsresultaten.

In het zesde hoofdstuk is een studie beschreven waarin nader is onderzocht in hoeverre specifieke voorbereiding voor de voortgangstoets invloed heeft op het behalen van hogere toetsresultaten. Deze studie betreft een gerandomiseerde interventiestudie volgens een twee bij drie design. Met behulp van gegevens die zijn verkregen in de studie van hoofdstuk 5 zijn studenten willekeurig toegewezen aan drie onderzoekscondities, waarbij de onderzoekscondities zodanig zijn gerandomiseerd dat de helft van de wel en de andere helft niet studeerde voor de voorafgaande voortgangstoets. Als onderzoekscondities zijn de voorbereidende activiteiten gekozen die het meest werden verricht en waaraan de hoogste verwachtingen ten aanzien van effectiviteit werden toegekend, namelijk: 'bestuderen van oude aantekeningen' en 'in groepjes maken van oude toetsvragen'. "Niet studeren" gold als controleconditie. Bij de studenten binnen de controle-conditie is tevens een vragenlijst afgenomen over hun probleemgestuurd studiegedrag, waarmee de relatie tussen toetswoorbereiding en probleemgestuurd studiegedrag is onderzocht.

Op basis van deze studie blijkt dat studenten met studie-activiteiten die binnen probleemgestuurd onderwijs worden beoogd, degenen zijn met betere resultaten op de voortgangstoets. In hoeverre dit de consequentie is van deze activiteiten, dan wel betere cognitieve vermogens, dan wel overige vaardigheden, kan op basis van deze studie niet worden geconcludeerd. Wel kan worden geconcludeerd dat de niet beoogde specifiek toetsgerichte studieactiviteiten geen compenserend effect hebben voor studenten met minder goede toetsresultaten. Sterker nog, deze activiteiten hebben voor géén van de zes onderzoeksgroepen een effect. Als zodanig past de toets uitstekend binnen de rationale van probleemgestuurd onderwijs: een actieve studiehouding in de onderwijsgroep wordt beloond en compenserend toetsgerichte studieactiviteiten niet. 
Hoofastuk 7 vormt het discussiehoofdstuk van deze dissertatie. Volgens de indeling van het onderzoeksmodel van hoofdstuk 1 zijn de belangrijkste conclusies uit de vijf afzonderlijke studies geintegreerd, kanttekeningen geplaatst en implicaties benoemd. Achtereenvolgens zijn de invloed van probleemgestuurd onderwijs op studliegedrag, de invloed van voortgangstoetsing op studiegedrag en de invloed van studiegedrag op toetsresultaten besproken. Het hoofdstuk is afgesloten met aanbevelingen voor verder onderzoek, het onderwijs, de voortgangstoets en de afstemming tussen de voortgangstoets en het onderwijs.

De studie-activiteiten die studenten verrichten voortkomend uit probleemgestuurd onderwijs lijken positief. Volgens de zelfbeoordeling van studenten is hun gedrag voor en in de onderwijsgroepen redelijk overeenkomstig probleemgestuurd onderwijs. De studie-activiteiten worden betrekkelijk regelmatig gespreid over een blokperiode verricht.

Studenten laten zich met hun studie-activiteiten ook beïnvloeden door voortgangstoetsing. De voortgangstoets geeft bij een redelijke grote groep studenten aanleiding tot toetsgericht studiegedrag. Echter, de aard van de activiteiten waartoe de toets aanstuurt is redelijk positief, de omvang in tijd is beperkt en het aantal studenten waarbij deze activiteiten gaan ten koste van de onderwijsgroep is zeer gering. Zorgwekkend is dat empirisch blijkt dat een zeer groot aantal studenten zichzelf benadeelt door het volgen van de huidige antwoordinstructie (gebruik wanneer je een antwoord niet weet het vraagteken) bij de huidige goed-min-fout scoring. Vragen beantwoorden met een bepaalde mate van onzekerheid (of mate van gokken) leidt namelijk bij goedmin-fout scoring tot hogere toetsresultaten.

Probleemgestuurd studiegedrag draagt significant bij aan het voorspellen van voortgangstoetsresultaten. De beloning in de vorm van hogere toetsresultaten voor gewenste studie-activiteiten in en voor de onderwijsgroep is voor studenten nauwelijks zichtbaar. Regelmatige voorbereiding van de onderwijsgroepsbijeenkomsten wordt niet beloond met hogere toetsresultaten. Echter, ook ongewenste specifieke toetsvoorbereiding blijkt niet te leiden tot hogere toetsresultaten.

De voortgangstoets heeft dus weinig negatieve invloed op studiegedrag. Bovendien is de voortgangstoets niet strijdig met probleemgestuurd onderwijs gelet op de studie-activiteiten waar de toets aanleiding toe greeft en de studie-activiteiten die wel en niet worden beloond. Met de voortgangstoets 
worden in bescheiden mate verschillen in studiegedragingen en kwaliteit van studie-activiteiten zichtbaar gemaakt in studieresultaten. Het gebruiken van de sturende werking van een toets om studenten tot bepaalde (gewenste) studie-activiteiten te activeren lijkt nu (nog) weinig aangewend. Het potentieel van de voortgangstoets zou verder ontwikkeld kunnen worden wanneer een alternatief wordt gevonden voor de huidige scoringsregel. Wellicht is de toekenning van een formatieve waarde voor de toetsscore in combinatie met een summatieve waarde voor de wijze waarop gebleken kennishiaten worden weggewerkt een manier waarop de voordelen van de voortgangstoets niet worden aangetast en de nadelen van huidige scoringsregel worden omgebogen tot een positieve sturingsfactor. In totaliteit kan de onderzoeksvraag van deze dissertatie over de aansluiting van de voortgangstoets op probleemgestuurd onderwijs positief worden beantwoord. Het laat dan ook zien dat het strategisch toepassen van toetsing in het stimuleren van student-activiteiten een geschikte en waardevolle strategie is, terwijl daar tot nu toe nog weinig van wordt geprofiteerd. 


\section{Summary}

The steering influence of assessment on students' study activities is a dominating factor in any educational training program. This requires an assessment approach to be congruent with the educational program, otherwise assessment will undermine the educational goals. Therefore, evaluation of the impact of an assessment procedure on students" learning behavior is essential. The central question of this dissertation concerns the appropriateness of progress testing within a problem-based educational context. Five studies have been conducted focusing on specific aspects of problem-based learning or progress testing. The investigated aspects included the "don't know' option under formula scoring (correct minus incorrect scoring), the quality of students' problem-based learning behavior, regularity of individual study activities for the tutorials, the absence or presence of specific testdirected learning behavior and the effectiveness of specific test-directed. learning behavior. In five studies each of these aspects has been investigated and described in a separate chapter.

Chapter 1 provides an introduction to the context of this dissertation and the respective studies. This chapter explains the focus of this dissertation on educational influences of assessment. Furthermore this chapter provides a description of the educational context, problem-based learning, and the assessment measure under study, progress testing.

In problem-based leaming students have a central role in defining their learning objectives and acquiring information. In a small group discussion, called tutorials students meet twice a week to discuss problems. In one tutorial session they analyze a single problem and subsequently define learning objectives on what they need to know to solve the problem. After having defined the learming objectives as a group, they try to find answers to their learning objectives, by individual study. In the next tutorial session they discuss what they have found in such a way that they demonstrate understanding of the material learned. In the construction of knowledge, the activation of prior knowledge, social interaction and learning in context help to enrich the newly constructed knowledge and improve accessabillity and retention. 
The students" knowledge has to be assessed. To be congruent with the educational principles of problem-based learning, the examination program has to encourage self-directed learning, stimulate the formulation of individual learning objectives and focus on understanding. It should disencourage testdirected studying and rote memorization.

Progress testing is a form of end-of-course testing, intended to be congruent with educational principles of problem-based learning. With progress testing the direct relationship between the specific educational training program and the assessment has been cut. The progress test is a comprehensive test which samples knowledge of all disciplines and content areas of a specific educational training program. Several times a year all students in the curriculum regardless of their year, are submitted to a newly constructed form of the test. A single test question may be answered with either true or false, or with a "don't know' option. A correct answer is rewarded with one mark, an incorrect answer is given a negative mark while a 'don't know' option is neither penalized nor rewarded. The instrument presumes to measure functional knowledge and not to discourage self-directed learning. The test. should not reward 'study for the test' behavior.

The five studies of this dissertation have been conducted in the Health Sciences Faculty. This faculty includes training programs in Health Policy and Health Management, Health Promation and Health Education, Nursing Science, Mental Health Science, Theory of Health Sciences, Movement Sciences and Biological Health Science. In this faculty the progress test consists of 400 items and is taken three times a year.

At the end of this chapter research questions are formulated, derived from the assumed influence of progress testing and problem-based learning on students' learning behavior. The chapter concludes with a model in which the variables of the separate studies are summarized in an integral way.

Chapter 2 describes a study to what extent students use the "don't know" option. Correct minus incorrect formula scoring with a "don't know" option is introduced to allow students the freedom to deline their own learning objectives. The study explores students' answering behavior by exploring how confident they are about their knowledge in answering a question or when using the "don't know" option. The study uses a regular progress test under a normal test condition, immediately followed by an experimental progress 
test. In the experimental progress test the "don't know" option has been replaced by a probability-estimate of how certain a student is about his or her answer on a five-point Likert scale.

The study reveals that a substantial number of students indicate that even at the end of their study, they have no knowledge about a large portion of the questions. In spite of this, hardly any questions are answered by pure guessing. For questions previously answered with a 'don't know' which were subsequently forcefully answered during the experimental test, the proportion of correct answers exceeds the proportion of incorrect answers. However "the proportion of correct answers varies between students. This variation does not seem clearly related to risk taking behavior in using or not using the 'don't know" option. It seems that under correct minus incorrect formula scoring, students with the most knowledge are most penalized.

The study shows that the correct minus incorrect formula scoring introduces bias because students do not equally use the 'don't know' option. The an swering instruction usually given at the regular progress test, insufficiently emphasizes the optimal answering strategy.

Chapter 3 describes a study investigating variations in students' learning activities; conceptualized as the extent to which students use the problembased systematic working procedure. Students' problem-based learning behavior is subsequently related to specific test-directed learning behavior and to achievement on the progress test.

The study uses a self-assessment questionnaire of behavioral profiles reflecting concrete leaming situations in problem-based learning. In the questionnaire problem-based learning behavior is operationalized as an integrated concept of two dimensions of students" behavior, namely: (1) how students study, their study approach, called the 'style' of their problem-based learning behavior, and (2) what students do: their activities and behaviors when they use the problem-based systematic working procedure, called the "activity' of problem-based learning behavior. In the questionnaire, students' behavior both during tutorial groups as well as during individual study is regarded as part of problem-based learning behavior.

The results of this study indicate that there is hardly any correlation between problem-based learning behavior and students" test-directed learning for the progress test. It seems that students' problem-based learning behav- 
ior in the tutorials is unrelated to wether or not they specifically study for the test. Furthermore, the modest sterring effect found of progress testing appears not to contribute to higher test scores, whereas problem-based learning behavior contributes significantly to higher test scores.

Chapter 4 reports on a study investigating the regularity of students' learning behavior within a problem-based educational block-period and its relationship to test scores. In this study both scores on the progress test and block test are investigated. The difference between the progress test and the block test is that the latter concerns on end of-unit test which contains a relatively defined knowledge-domain and subsequently has a direct relationship with a specific part of the educational training program.

During an eight-week period students marked the time they spent on specified parts and activities of their program and time spent on 'studying-for-thetest'. They also completed the problem-based learning behavior questionnaire described in chapter 3 .

The results of this study show that during a six-week block-period students distribute their learning activities quite regularly from start to end. In addition to regular learning activities for the tutorials, students also specifically 'study-for-the-test'. The regularity of learning activities, for both the progress test and the block test, appears not to contribute significantly to higher testscores. As in chapter 3, again problem-based learning behavior does contribute to higher progress test-scores. This time, however, problem-based learning behavior did not contribute to higher block test-scores.

In conclusion, with progress testing the intended regularity of learning activities is not specifically rewarded. The intent of the progress test to prevent steering of test-directed study behavior has only partly been attained. However; it is encouraging that progress testing seems to interfere less with other educational activities than block-testing.

Chapter 5 concerns a descriptive study looking at the 'study-for-the-test" activities of students in relation to the progress test, and how much time they spend on these activities. The results of this study indicate that a substantial group of students prepares specifically for the test. The amount of time is, on average, limited to just one and a half hours (three hours on average, excluding students not preparing). The activities students mostly 
engage in, can be characterized as relative acceptable and aimed at refresh ing knowledge. They include reviewing old progress tests, looking over old notes from previous training-blocks and scanning some texts or articles. Moreover, only a very small group of students answers that their testpreparation-activities are at the expense of their learning activities for the tutorials. Whether or not test-preparation-activities have a positive effect on test-results, remains unclear in this study.

In chapter 6 a randomized intervention study was carried out to examine the effect of specific test-preparation-activities on test-results. A two by three design was used, with half of the students who previously indicated that they do prepare and half of the students who indicated not to prepare for the last progress test. The groups were assigned to three different test preparation conditions. The test preparation conditions were: (1) individually one hour of studying previously made notes, lectures and (individual) learning objectives gathered during the block-periods, (2) in small groups of students one hour of answering and discussing items of old progress tests and (3) a control group who did not study for the test at all and only had to answer some questionnaires about learning behavior unrelated to this study. As a result there were six different experimental groups, balanced for equal past achievement levels and preparation time. All groups were given a progress test to complete.

The results clearly indicate that specific test preparation does not influence test-scores. Within none of the preparation conditions students achieve higher test scores than the control group, regardless whether students for previous progress tests were used to prepare for it or not. Overall, the results seem to indicate that study-for-the-test activities are not very effective for progress test achievement. It seems that when achievement differences are found between preparing and non-preparing students, they are probably a reflection of differences in competency.

In chapter 7 the general conclusions, discussion and implications of the results that emerged from the separate studies are formulated. This chapter follows the structure of the research-model which was given in chapter 1. Successively the influence of problem-based learning on students' learning activities, progress testing on students' learning activities, and students" 
learning activities on testscores are being discussed. This chapter ends with recommendations for further research, implications for the educational training program, implications for progress testing and ideas to strengthen the congruence between progress testing and the educational training program.

The conclusion about the influence of problem-based learning on students' learning behavior is that most students recognize their activities in profiles with deep active problem-based learning behavior. They distribute their activities regularly within a block period while the specific test-directed learning activities they adopt hardly disturb their regular learning activities for the tutorials.

The conclusion about the impact of progress testing on students' learning behavior is that a large group of students adopt specific test-directed learning activities, although most of these activities are quite uncontroversial and aimed at refreshing knowledge; they are limited in time. Only for a very restricted group, test preparation goes at the expense of their regular learning activities for the tutorials. The empirical finding that a group of students perform worse just because they follow the usual answering instruction, needs serious reconsideration. Even by answering with a low probability estimate the number of correct answers exceeds the number of incorrect answers.

Adequate problem-based learning behavior significantly contributes to achievement on the progress test. The gain in test scores however seems too marginal to provide a proper incentive for this kind of learning behavior. Students" regularity of learning behavior does not increase the explanation of variance in progress testscores. On the other hand, unintended specific test preparation behavior does not influence achievement on the progress test.

In summary this means that progress tests hardly have negative effects on students' problem-based learning behavior. In the absence of negative stimuli on students" learning behavior, the progress test matches the self-directed problem-based educational context. Moreover, unintended activities like specific study-for-the-test behavior, are not rewarded while intended activities, like problem-based learning behavior, are rewarded. The test modestly reinforces differences in learning behavior and the quality of learning activities. Therefore, the progress test also has fewer positive effects on students' learning behavior then expected. 
The potential of the progress test could be reinforced when an alternative scoring rule were to be found, one that prevents the disadvantages of the formula strategy and which takes advantage of the steering influence of testing. Overall the research question of this dissertation on the match between progress testing and problem-based learning can be answered positively. It therefore demonstrates that the strategic use of assessment to drive student learning, something which has hardly been practiced before despite its apparent relevance, is a feasible and worthwhile strategy. 



\section{Referenties}

Albanese, M. A., Mitchel, S. (1992). Problem-based learning: a review of literature on its outcomes and implementation issues. Academic Medicine, $68(1), 52-81$.

Barrows, H. S., Tamblyn, R.M. (1980). Problem-based learing. New York: Springer.

Berkel, H. J. M. van. (1990). Assessment in a problem-based medical curriculum. Higher Education, 19, 123-146.

Berkel, H. J. M. van., Sprooten, J., Graaff, E. de. (1993). An individualized assessment test consisting of 600 items. In P. A. J. Bouhuijs, Schmidt, H.G., Berkel, H.J.M. van (Ed.), Problem-based learning as an educational strategy. Maastricht, Netherlands: Network Publications.

Berkel, H. J. M. van, Nuy, H.J.P., Geerligs, T. (1995). The influence of progress tests and block tests on study behaviour. Instructional Science, 22, $317-333$.

Berkel, H. J. M. van, Til, C.T. van, Sprooten, M.A.M.B. (1996). Voortgangstoetsen 1995/1996. Analyse van de hernieuwde voortgangstoetsen in studiejaar 1995/1996 Interne uitgave Faculteit der Gezondheidswetenschappen). Maastricht: Universiteit Maastricht.

Berkel, H. J. M. van. (1996). Voortgangstoets-enquete (Interne uitgave Faculteit der Gezondheidswetenschappenj. Maastricht: Universiteit Maastricht.

Biggs, J. B. (1976). Individual differences in study processes. British Journal of Educational Psychology, 46, 185-212.

Biggs, J. B. (1979). Individual differences in study processes and the quality of learning outcomes. Higher Education, 8, 381-394.

Blake, J.M., Keane, D. R., Norman, G.R., Mueller, C.B. (1994). Introducing progress testing in a traditional problem based curriculum: impact on student learning, in Research in Medical Education (Abstracts) (Washington: AAMC).

Blake, J. M., Norman, G.R., Kinsey, E., Smith, M. (1995). Report card from McMaster: student evaluation at a problem based medical school. The Lancet, 345 (april 8), 899-902. 
Blake, J. M., Norman, G.R., Keane, D.R. Mueller, M.D., Cunnington, J., Didyk, N. (1996). Introducing progress testing in McMaster University's problem-based medical curriculum: psychometric properties and effect on learning. Academic Medicine, 71(9), 1002-1007.

Budescu, C., Bar- Hillel, M. (1993). To guess or not to guess: a decisiontheoretic view of formula scoring. Joumal of Educational Measurement, $30(4), 277-291$.

Cizek, G. J. (1993). Rethinking psychometricians' beliefs about learning. Educational Researcher, 4(22), 4-9.

Cohen-Schotanus, J. (1994). Effecten van curriculumveranderingen: studiewaardering, studeergedrag, kennis, studiedoorstroom in een veranderd medisch curriculum. Academisch Proefschrift, Rijksuniversiteit Groningen, Groningen.

Coles, C. (1985). Differences between conventional and problem-based curricula in their students' approaches to studying. Medical Education, 19, 308-309.

Conway, M. A., Cohen, G., Stanhope, N. (19911). On the very long-term retention of knowledge acquired through formal education: twelve years of cognitive psychology. Journal of Experimental Psychology: General, 120[4], 395-409.

Crombag, H. F. M., Gruijter, D.N.M. de, Ende, P. van de, Vos, P. (1980). De nieuwe propedeuse in de faculteit der rechtsgeleerdheid: verslag over het eerste semester. (rapport nr. 20). Leiden: Buro Onderzoek van Onderwijs.

Crombag, H. F. M., Vos, P. (1982). De invloed van tijdschrijven op studieinspanning en studieresultaat. Tijdschrift voor Ondenwijsresearch, 7(3), 97 108.

Cross, L. H., Frary, R.B. (1977). To guess or not to guess: a decision-theoretic view of formula scoring of multiple-choice test. Journal of Educational Measurement, 14(4), 44-47.

Dickinson, D. J., O'Connell, D. Q. (1990). Effect of quality and quantity of study on student grades. Journal of Educational Research, 83(4), 227-231.

Dirkzwager, A. (1996). Scoringsregels en toetsinstructie. Tijdschrift voor Onderwijsresearch, 3(21), 272-277. 
Dousma, T., Horsten, A., Brants, J. (1989). Tentamineren. (3 ed.). Groningen: Wolters-Noordhoff b.v.

Drift, K. D. J. M. van der, Vos, P. (1987). Anatomie van een leeromgeving: een onderwijseconomische analyse wan universitair onderwijs. Academisch Proefschrift, Rijksuniversiteit Leiden, Leiden.

Ebel, R. L. (1970). The case for true-false test items. School Review: a joumal of secundary education, 78(3), 373-389.

Ellis, J. A., Wulfeck W.H., Montague, W.E. (1980). The effect of adjunct and test question similarity on study behavior and learning in a training course. American Educational Research Joumal, 17(4), 449-457.

Endler, N. S. (1988). Interactionism revisited: a discussion of "on the role of situations in personality research". In S. G. Cole, Demaree, R.G. (Ed.), Applications of interactionist psychology: Essays in honor of Saul B. Sells. (pp. 179-188). Hillsdale, N.Y.: Erebaum.

Endler, N. S., Parker, J.D.A. (1992). Interactionism revisited: reflections on the continuing crisis in the personality area. European Journal of Personality, 6, 177-198.

Entwistle, N. J., Ramsden, P. (1983). Understanding student leaming. London: Croom Helm.

Entwistle, N. (1988). Motivational factors in students' approaches to learning. In R. R. Schmeck (Ed.), Learning strategies and learning styles. (pp. 2149). New York and London: Plenum Press.

Frary, R. B. (1980). The effect of misinformation, partial information, and guessing on expected multiple-choice test item scores. Applied Psychological Measurement, 4[1], 79.90.

Frederiksen, N. (1984). The real test bias: influences of testing on teaching and learning. American Psychologist, 39(3), 193-202.

Gagné, E. D., Yekovich, C.W., Yekovich, F.R. (1993). Cognitive psychology school leaming. (2 ed.). New York: Harper Collins College Publishers.

Gaynor, J., Millham, J. (1976). Student performance and evaluation under variant teaching and testing methods in a large college course. Joumal of Educational Psychology, 68(3), 312-317. 
Geerligs, T. (1993). De voortgangstoets Gezondheidswetenschappen in de ogen van de studenten. (Interne uitgave Faculteit der Gezondheidswetenschappen). Maastricht: Universiteit Maastricht.

Gelderen, A. van, Cate, O. ten. (1985). Vrijwilligerseffecten in tijdschrijfonderzoek. Tijdschrift voor Onderwijsresearch, 10, 149-160.

Gordon, M. J. (1991). A review of the validity and accuracy of self assessments in health professions training. Academic Medicine, 66, 762-769.

Grave, W. S. de. (1993). Effectief studiegedrag van studenten in de onderwijsgroep (Interne uitgave Faculteit der Geneeskunde). Maastricht: Universiteit Maastricht.

Grave, W. S. de., Boshuizen, H.P.A., Schmidt, H.G. (1996). Problem-based learning: cognitive and metacognitive pracesses during problem analysis. Instructional science, 24, 321-341.

Gross, L. J. (1982). Scoring multiple true/false tests; some considerations. Evaluation and the Health Professions, 5(4), 459-468.

Grosse, M. E., Wright, B.D. (1985). Validity and reliability of true-false tests. Educational and Psychological Measurement, 45, 1-13.

Hakstian, A. R. (1971). The effects of type of examination anticipated on test preparation and performance. The Journal of Educational Research, 64(7), 319-324.

Hakstian, A. R., Kansup, W. (1975). A comparison of several methods of assessing partial knowledge in multiple-choice tests: II. Testing procedures. Journal of Educational Measurement, 12(4), 231-239.

Halpin, G., Halpin, G. (1982). Experimental investigation of the effects of study and testing on student learning, retention, and ratings of instruction. Joumal of Educational Psychology, 74(1), 32-38.

Hillard, R. I. (1995). How do medical students learn: Medical student learning styles and factors that affect these learning styles. Teaching and Leaming in Medicine, 7(4), 201-210.

Hol, T. P. M. (1994). Persoon - situatie interacties: operationalisering, gedragsvoorspelling en modelvergelijking. Academisch Proefschrift, Katholieke Universiteit Brabant, Tilburg.

Hutchinson, T. P. (1986). Evidence about partial information from an answer-until-correct administration of a test of spatial reasoning. Contemporary Educational Psychology, 11, 264-275. 
Jansen, E. P. W. A. (1996). Curriculumorganisatie en studievoortgang: Een onderzoek onder zes studierichtingen aan de Rijksuniversiteit Groningen. Academisch Proefschrift, Rijksuniversiteit Groningen, Groningen.

Leeuwen, Y. D. van. (1995). Growth in knowledge of trainees in generai practice. Figures and facts. Academisch Proefschrift, Universiteit Maastricht, Maastricht.

Lindeman, R. A., Cabret, M.L. (1995). Assessment of dental student studying strategies. Joumal of Dental Education, 59(11), 1020-1026.

Linn, R. L. (1993). Educational assessment: expanded expectations and. challenges. Educational Evaluation and Policy Analysis, 15(1), 1-16.

Lonka, K., Lindblom-Ylänne, S. (1996). Epistemologies, conceptions of learning, and study practices in medicine and psychology. Higher Education, 31 , 5-24.

Marton, F., Säljö, R. (1984). Approaches to learning. In F. Marton, Hounsell, D., Entwistle, N. (Ed.), The experience of leaming (pp. 36-55). Edinburg: Scottish Academic Press.

Meerum Terwogt-Kouwenberg, K. (1990). Niet gewogen toch te licht bevonden: Analyse van de rendementsproblematiek aan de universiteit. Academisch Proefschrift, Universiteit van Amsterdam, Kampen.

Meyer, J. H. F. (1991). Study orchestration: the manifestation, interpretation and consequences of contextualised approaches to studying. Higher Education, 22, 297-316.

Moust, J. H. C., Schmidt, H.G., Volder, M.L. de, Belien, J.J.J., Grave, W.S. de. (Ed.). (1986). Effects of verbal participation in small group discussions on learning. Guilford: Society for research into higher education.

Moust, J. H. C., Bouhuijs, P.A.J., Schmidt, H.G. (1989). Probleemgestuurd leren. Een wegwijzer yoor studenten. (2 ed.). Groningen: Wolters-Noordhoff.

Moust, J. (1993). De rol van tutoren in probleemgestuurd onderwijs. Contrasten tussen student en docent-tutoren. Academisch Proefschrift, Rijksuniversiteit Limburg, Maastricht.

Moust, J. H. C., Bouhuijs, P.A.J., Schmidt, H.G. (1997). Probleemgestuurd leren. ( 3 ed.). Groningen: Wolters-Noordhoff. 
Newble, D. I., Jaeger K. (1983). The effect of assessment and examinations on the learning of medical students. Medical Education, 17, 165-171.

Newble, D. I., Clarke, R.M. (1986). The approaches to leaming of students in a traditional and in an innovative problem-based medical school. Medical Education, 20, 267-273.

Newble, D. I., Entwistle, N.J. (1986). Learning styles and approaches: implications for medical education. Medical Education, 20, 162-175.

Newble, D. (1988). Eight years" experience with a structured clinical examination. Medical Education, 22, $200-204$.

Norman, G. R. (1988). Problem solving skills, solving problems and problem based learning. Medical Education, 22, 279-286.

Norman, G., Allerly, L., Berkson, L., Bordage, G., Cohen, R., Dauphinee, D., Davis, W., Friedman, C., Grant, J., Lear, P., Morris, P., Vleuten, C. van der. (1989). Research in the psychology of clinical reasoning: implications for assessment. Paper presented at the Proceedings of Cambridge Conference IV, University of Cambridge.

Norman, G. R. (1991). What should be Assessed? In D. Boud, Felett, G. (Ed.). The challenge of problem based learning. (pp. 254-259). London: Kogan Page.

Norman, G. R., Vleuten, C.P.M. van der, Graaff, E. de. (1991). Pitfalls in the persuit of objectivity: issues of validity, efficiency and acceptability. Medical Education, 25, $119-126$.

Norman, G. R., Schmidt, H. G. (1992). The psychological basis of problembased learning. A review of the evidence. Academic Medicine, 67(9), 557 565.

Norman, G., Regehr, G. (1994, 26-29 juni). Contemporary issues in cognitive psychology: implications for professional education. Paper presented at the sixth Ottawa conference on medical education, Toronto, Ontario, Canada.

Pask, G. (1976). Styles and strategies of learning. British Joumal of Educational Psychology, 46, 128-148.

Pollemans, M. (1994). Kennistoetsing bij huisartsen. Academisch Proefschrift, Universiteit Maastricht, Maastricht.

Post, G. J. D., Drop, M.J. (1990). Perceptions of the content of the medical curriculum at the medical faculty in Maastricht: A comparison with traditional curricula in the Netherlands. In Z. M. Nooman, Schmidt, H.G., 8 
Ezzat, E.S. (Ed.), Innovations in medical education: an evaluation of its present status (pp. 64-75). New York: Springer Publishing Compagnie.

Richards, B. F., Cariaga-Lo, L. (1994). Curriculum type and sophomore students' preparation time for the USMLE step 1 examination. Evaluation and the Health Professions, 17(3), 329-343.

Rossum, E. J. van, Schenk, S.M. (1984). The relationship between learning conception, study strategy and learning outcome. British Joumal of Educational Psychology, 51, 73-83.

Rowley, G. L., Traub, R.E. (1977). Formula scoring, number-right scoring, and test-taking strategy. Journal of Educational Measurement, 14(1), 15-22.

Schmidt, H. G. (1983). Problem-based learning: rationale and description. Medical Education, 17, 11-16.

Schmidt, H. G. (1993). Foundations of problem-based learning: some explanatory notes. Medical Education, 27, 422-432.

Schmidt, H. G., Machiels-Bongaerts, M., Hermans, H., Cate, T.J. ten, Venekamp, R., Boshuizen, H.P.A. (1996). The development of diagnostic competence: comparison of a problem-based, an integrated, and a conventional medical curriculum. Academic Medicine, 71(6), 658-664.

Schouwenburg, H. C. (1994). Uitstelgedrag bij studenter. Academisch Proefschrift, Rijksuniversiteit Groningen, Groningen.

Schuwirth, L. W. T., Verhoeven, B.H., Scherpbier, A.J.J.A., Mom, E.M.A., Cohen-Schotanus, J., Van Rossum, H.J.M., Vleuten, C.P.M. van der. (onder editorial review). An inter-and intra-university comparison in clinical problem-solving skills. Advances in Health Sciences Education.

Semb, G. B., Ellis, J.A. (1994). Knowledge taught in school: what is remembered? Review of Educational Research, 64(2), 253-286.

Sherriffs, A. C., Boomer, D. S. (1954). Who is penalized by the penalty for guessing. The Joumal of Educational Psychology, 45, 81-90.

Slakter, M. J. (1968). The effect of guessing strategy on objective test scores. Journal of Educational Measurement, 5(3), 217-222.

Snyder, B. R. (1971). The hidden curriculum. New York: Knopf.

Specht, L. B., Sandlin, P.K. (1991). The differential effects of experimental learning activities and traditional lecture classes in accounting. Simulation \& Gaming, 2(22), 196-210. 
Spectrum. (1996, oktober). Studenten over de voortgangstoets: gezellig samenzijn, leuk, zinloos, achterhaald idee, best goed, moet bijven! Intem. nieuwsblad van de Faculteit der Gezondheidswetenschappen, 7-8.

Sprooten, M. A. B. J., Vleuten, C.P.M. van der. (1983). The measurement of growth in medical knowledge in a non-departmental organized medical school. Paper presented at the Proceedings of the twenty-second annual conference on research in medical education, Washington, U.S.A.

Studiegids Faculteit der Gezondheidswetenschappen. (1993/1994. 1996/1997). Maastricht: Faculteit der Gezondheidswetenschappen: Universiteit Maastricht.

Swanson, D. B., Case, S.M., Vleuten, C.P.M. van der. (1991). Strategies for student assessment. In D. Boud, Feletti, G. (Ed.), The challenge of problem based learning. London: Kogan Page.

Thomas, R. E. (1997). Problem-based learning: measurable outcomes. Medical Education, 31, 320-329.

Til, C. van. (1995). De studietijd van propaedeuse studenten: een onderzoek naar de hoeveelheid en verdeling van studietija in blok 1.4. (Interne uitgave Faculteit der Gezondheidswetenschappen). Maastricht: Universiteit Maastricht.

Til, C. T. van, Berkel, H.J.M. van. (1995), De invloed van de vraagtekenoptie op de toetsscore bij kennistoetsen met juist/onjuist vragen. In J. Pols, Cate, T.J. ter, Houtkoop, E., Pollemans, M.C., Smal, J.A. (Ed.), Gezond Ondenwijs Congres 4 (pp. 289-294). Houten/Zaventem: Bohn Stafleu Van Loghum.

Til, C. T. van, Berkel, H.J.M. van, Vleuten, C.P.M. van der. (1996). Voortgangstoetsscores en wijze van toetsvoorbereiding bij verschillend probleemgestuund studiegedrag. In T. J. t. Cate, Dikkers, J.H., Houtkoop, E., Pollemans, M.C., Smal, J.A. (Ed.), Gezond Onderwijs Congres 5 (pp. 395-401). Houten/Diegum: Bohn Stalleu Van Loghum.

Til, C. T. van, Vleuten, C.P.M. van der, Berkel, H.J.M. van. (1997, maart 2428). Problem-based leaming behavior: the impact of differences in problembased leaming style and activity on students' achiewement. Paper presented at the Annual Meeting of the American Research Association, Chicago (ERIC Document Reproduction Service No. TM026783). 
Til, C. T. van, Pronk, M., Heijden, F.M. van der. (1997). Evaluatie studievaardigheden PGO. evalwatie van de nieuwe opzet van de training en invoering wan het vaardigheden logboek (Interme uitgave Faculteit der Gezondheidswetenschappen). Maastricht: Universiteit Maastricht.

Til, C. T. van, Vleuten, C.P.M. van der, Berkel, H.J.M. van. (1997). Invloed van regelmaat van studeren binnen $\mathrm{PGO}$ op de studieresultaten van studenten. In J. A. Smal, Cate, J.A. ten, Dennekens, J., Dikkers, J.H., Remmen, R., Spaai, G.W.G., Verweij, A.M.J.J. (Ed.), Gezond Onderwijs Congres 6 (pp. 247-254). Houten/Diegum: Bohn Stafleu Van Loghum.

Til, C. T. van, Vleuten, C.P.M. van der, Berkel, H.J.M. van. (1997, november). Leerstijlen en studiegedrag binnen $\mathrm{PGO}$ : de relatie tussen zelfstudie-activiteiten en gedrag in de onderwijsgroep. Paper gepresenteerd op het Gezond Onderwijs Congres, Veldhoven.

Trigwell, K., Prosser, M. (1991). Relating approaches to study and quality of learning outcomes at the course level. British Joumal of Educational Psychology, 61, 265-275.

Vermunt, I. D. H. M. (1992). Leerstijlen en sturen van leerprocessen in het hoger onderwijs: naar procesgerichte instructie in zelfstandig denken. Academisch Proefschrift, Katholieke Universiteit Brabant, Amsterdam/Lisse: Swets \& Zeitlinger.

Vermunt, J. D. (1996). Metacognitive, cognitive and affective aspects of learning styles and strategies: a phenomenographic analysis. Higher Education, 31, 25-50.

Vernon, D. T., Blake, R.L. (1993). Does problem-based learning work? A meta-analysis of evaluative research. Academic Medicine, 68(7), 550-563.

Verwijnen, G. M., Imbos, T. (1978). Evaluatie aan de medische faculteit Maastricht. Metamedica, 57, 21-32.

Verwijnen, M., Vleuten, C.P.M. van der, Imbos, T. (1987). A comparison of an innovative medical school with traditional schools: an analysis in the cognitive domain. In Z. M. Nooman, Schmidt, H.G., Ezzat, E.S. (Ed.), Innovation in Medical Education: an evaluation of its present sitatus (pp. 4049). New York: Springer Publishing Company.

Vleuten, C. P. M. van der. (1989). Naar een rationeel systeem voor toetsing van studieprestaties in probleengestuurd medisch onderwijs. studies naar 
betrouwbaarheid en validiteit van toetsen voor praktische vaardigheden. Academisch Proefschrift, Rijksuniversiteit Limburg, Maastricht.

Vleuten, C. P. M. van der, Norman, G.R., Graaff, E. de. (1991). Pitfalls in the pursuit of objectivity: issues of reliability. Medical Education, 25, 110-118.

Vleuten, C. P. M. van der, Newble, D.I., Case, S., Holsgrove, G., McCann, B., McRae, C. , Saunders, N. (1994). Methods of assessment in certivication. In D. I. Newble, Jolly, B., Wakeford, R. (Ed.), The certification and recertification of doctors: issues in the assessment of clinical competence (pp. 1.05-125). Cambridge: Cambridge University Press.

Vleuten, C. P. M. van der, Scherpbier, A.J.J.A., Wijnen, W.H.F.W, Snellen, H.A.M. (1996). Flexibility in learning: a case report on problem-based learning. International Higher Education, 17-24.

Vleuten, C. P. M. van der, Verwijnen, G.M., Wijnen, W.H.F.W. (1996). Fifteen years of experience with progress testing in a problem-based learning curriculum. Medical Teacher, 18(2), 103-109.

Vleuten, C. P. M. van der, Verwijnen, G.M., Holdrinet, R.S.G., Oeseburg, B., Bulte, J.A., Leunissen, R.R.M. (1996). Naar een interfacultaire voortgangstoets, resultaten van proefafnames. Bulletin Medisch Onderwijs, 15, 1-7.

Vleuten, C. P. M. van der (1996). The assessment of professional competence: developments, research and practical implications. Advances in Health Sciences Education, 1(1), 41-67.

Wijnen, W. H. F. W. (1973); Ja/nee: een toetsprocedure met mogeliikheden

Onderzoek van Onderwijs, 2(1), 12-14.

Wijnen, W. (1977). Einddoel-toetsen: waarom en hoe? Onderzoek van Onderwijs, 6(3), 16-19.

Wijnen, W. H. F. W., Vleuten, C.P.M. van der. (1985). Toetsing: hordenloop of voortgangscontrole? Universiteit en Hogeschool, 6(31), 270-279.

Wijnen, W. H. F. W. Bouhuijs, P.A.J. (1986). The Maastricht progress test: an example of comprehensive knowledge testing. Paper presented at the $97 \mathrm{th}$ Annual Meeting AAMC, New Orleans.

Wijnen, W. H. F. W. (1993). Probleemgestuurd leren erı voortgangstoetsen. In M. J. F. Hulshof, Bevers, J.A.A.M., Willems, J.M.H.M. (Ed.), Universiteit en diversiteit: Liber amicorum voor Hans van Hout (pp. 162-170). Nijmegen: IOWO. 
Williams, S. M. (1992). Putting case-based instruction into context: examples from legal and medical education. The Joumal of the Learning Sciences, $2(4), 367-427$.

Yang, J., Verheul, I.C., Verhelst, N., Essen, E. van. (1985). Vragen toetsen en verschil in studieactiviteiten onder invloed van toetsverwachting: Verslag van een enquête. Tijdschrift voor Onderwijsresearch, 10, 179-188.

Zeidner, M. (1987). Essay versus multiple-choice type classroom exams: the students perspective. Journal of Educational Research, 80(6), 352-358.

Zelfstudie Gezondheidswetenschappen. (1996). Maastricht: Faculteit der Gezondheidswetenschappen: Universiteit Maastricht. 



\section{Representativiteit deelnemende studenten studie 1}

Tabel 1 Vergelijking gemiddelde procentuele goed-min-fout score, absolute goed-score en absolute fout-score voor studenten die wel en studenten die niet hebben deelgenomen aan het onderzoek $(n=1553)$, getoetst met ANOVA

\begin{tabular}{|c|c|c|c|c|c|c|c|c|c|c|}
\hline & \multirow[b]{2}{*}{ deelname } & \multicolumn{3}{|c|}{$\%$ goed-min-fout } & \multicolumn{3}{|c|}{ absolute goed score } & \multicolumn{3}{|c|}{ absolute fout score } \\
\hline & & well & miet & F-waarde & wel & miet & F-waarde & wel & niet & F-waarde \\
\hline totaal & $(248 / 1305)$ & 41.5 & 11.1 & $1.355 \mathrm{~ns}$ & 75.5 & 74.0 & $0.459 \mathrm{~ns}$ & 43.8 & 42.3 & $0.002 \mathrm{~ns}$ \\
\hline eerstejaars. & $(78 / 199)$ & 7.6 & 7.0 & $2.310 \mathrm{~ns}$ & 50.4 & 46.4 & $1.669 \mathrm{~ns}$ & 21.4 & 19.8 & $0.533 \mathrm{~ns}$ \\
\hline tweedejaars & $(74 / 373)$ & 11.5 & 10.5 & $2.728 \mathrm{~ns}$ & 76.7 & 68.2 & $5.215 \mathrm{~ns}$ & 33.2 & 28.1 & $4217 *$ \\
\hline dendejaars & $(62 / 352)$ & 13.9 & 12.4 & $5.508 *$ & 87.8 & 81,4 & $3.172 \mathrm{~ns}$ & 35.1 & 34.3 & $0.119 \mathrm{~ns}$ \\
\hline vierdejaars & $(37 / 381)$ & 15.9 & 12.7 & $15.846^{\text {*and }}$ & 105.3 & 87.1 & $8.856 \mathrm{~ns}$ & 44.9 & 38.8 & $1.583 \mathrm{~ns}$ \\
\hline
\end{tabular}

Tabel 2 Vergelijking gemiddelde absolute goed-min-fout score voor de verschillende versies van de experimentele voortgangstoets $(n=248)$, getoetst met ANOVA

\begin{tabular}{|c|c|c|c|c|c|}
\hline & propedeuse & $\begin{array}{l}\text { biologische } \\
\text { stroom }\end{array}$ & $\begin{array}{l}\text { gedrags- } \\
\text { stroom }\end{array}$ & $\begin{array}{l}\text { maatschappij } \\
\text { stroom }\end{array}$ & $F$-waarde \\
\hline propedeuse & $8.7(79)$ & 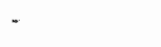 & $\cdots$ & - & - \\
\hline jaar 2 & - & $16.0(20)$ & $15.1(23)$ & $12.9(26)$ & $1.200 \mathrm{~ns}$ \\
\hline jaar 3 & . & $20.2(15)$ & $21.3(20)$ & $17.8(27)$ & $2.393 \mathrm{~ns}$ \\
\hline jaar 4 & - & $24.6(4)$ & $23.0(17)$ & $16.9(17)$ & $2.352 \mathrm{~ns}$ \\
\hline toltaal & 8.7 & 18.5 & 19.4 & 15.7 & $5.000^{*}$ \\
\hline
\end{tabular}



Voortgang' zoals dat in de titel is gegeven verwijst naar verschillende betekenissen 'continuiteit', 'verloop', wooruitgang' en voortbestaan'. Het mogen schrijven van dit dankwoord illustreert mijn voortgang van de afgelopen jaren. Velen hebben hun deel gehad aan deze voortgang. Helaas kan ik niet iedereen noemen die heeft bijgedragen aan het verrichten van de verschillende studies en het schrijven van de verschillende hoofdstukken, groeiende tot dit uiteindelijke product. Een aantal van hen wil ik met name noemen.

Allereerst bedank ik mijn co-promotor Henk van Berkel en promotor Cees van der Vleuten. Henk wist mij te overtuigen dat ik als Gezondheidswetenschapper zou kunnen bijdragen aan een onderwijskundig onderwerp. Zijn vertrouwen in mij heeft ertoe geleid dat ik aan dit promotie-onderzoek begon en nu zelfs volledig de weg van de onderwijskunde ben ingeslagen. Onze regelmatige discussies over onderwijs hebben een belangrijke bijdrage geleverd aan de vorming van mijn visie op onderwijs. Cees, met je enthousiasme, openheid en positieve instelling wist je vaak precies de juiste snaar te raken. Je bent belangrijk geweest in het plezier houden in deze klus. Naast je altijd constructieve en opbouwende feedback, is vooral de manier waarop je begeleidt en hoe je weet te motiveren, voor mij zeer waardevol geweest.

Mijn directe collega's van de vakgroep Onderwijsontwikkeling en Onderwijsresearch wil ik bedanken voor hun aandeel. De uitwisseling van ideeën, feedback op vragenlijsten, de inhoudelijke en persoonlijke gesprekken zijn voor mij waardevol geweest. Een aantal wan hen verruilde de vakgroep voor een andere aanstelling. Irma Kokx, Monique Mulders, Rina Vaatstra en Margje van de Wiel wil ik bedanken voor hun vriendschap en de persoonlijke belangstelling, die bleef nadat zij niet meer bij de vakgroep werkten.

In de afgelopen jaren heb ik met drie collega's lange of korte tijd de kamer gedeeld. Diana Dolmans, Marianne van den Hurk en Agnes Wagenaar bedank ik voor de gezelligheid die het 'kamerdelen' met zich meebracht. De eerste jaren heb ik veel profijt gehad van Diana als voorbeeld. lk heb gezien hoe zij naar de afronding van haar dissertatie toe werkte en heb ik vele kneepjes van het vak kunnen afkijken. Helaas orden ik mijn materialen nog 
steeds niet zo netjes als zij. Nog altijd hecht ik veel waarde aan haar mening en suggesties. In Marianne vond ik altijd een deelgenoot om eventjes te brainstormen over ideeën, zomaar te kletsen of mijn hart te luchten. Waarschijnlijk wisselden we in de maanden dat we de kamer deelden per dag minder woorden uit dan in de tijd erna. Agnes heeft bij het begin van haar aanstelling de afronding van mijn dissertatie van dichtbij meegemaakt. In korte tijd is een hechte betrokkenheid ontstaan.

Met de jarenlange aanwezigheid van Bert Kerkhofs op roep-afstand zijn vele grote en kleine computerprobleempjes telkens snel verholpen.

De student-assistenten Conny van den Heuvel, Henri in 't Groen en Miranda Pronk bedank ik voor hun hulp bij mijn andere taken, waarbij zij tussendoor ook nog 'even' hielpen met literatuur zoeken, assisteren bij een onderzoek en een belangrijk deel van de referentielijst samenstellen.

De medewerkers van bureau onderwijs, vooral Lilianne Hoogsteder, Math Reintjens, Toine Volckerick en Rina Devue, ben ik erkentelijk vour het beschikbaar stellen van gegeven, hun hulp bij de uitvoer van de verschillende studies en de ondersteuning bij de andere werkzaamheden.

De voortgang van de verschillende studies heb ik zeker ook te danken aan de welwillendheid van een groot aantal studenten Gezondheidswetenschappen. I $\mathrm{k}$ wil hun bedanken voor hun deelname, in het bijzonder degenen die tot zelfs tot drie keer toe in één var de steekproeven terechtkwamen en alle keren meededen.

De behulpzaamheid van Robert Peperkamp en Alexandra Stroosnijder met de afhandeling van "kleine" doch essentiële print- en correspondentie-zaken maakten dat het lukte om voor de zomer alles af te ronden. Bijzondere dank geldt daarbij ook voor Wilma van Meriënboer die op zeer korte termijn bereid was de Engelse samenvatting te corrigeren.

Francy van der Heijden heeft meer dan alleen als collega voor mij een belangrijke rol gespeeld in het voortgang 'creëren'. Francy, met je vragen, opmerkingen en reflecties leerde je me op een andere manier naar mijn werk en werkomgeving te kijken. Onze regelmatige (gezellige) gesprekken hebben me veel zicht gegeven op mogelijke wegen binnen het werk.

Mijn nieuwe collega's van de leerstoelgroep Agrarische Onderwijskunde van de Landbouwumiversiteit Wageningen, en in het bijzonder Jan Steen, ben ik bijzonder erkentelijk voor de ruimte die ze mij boden bij het doen van de laatste aanpassingen. 
Gelukkig bestond 'mijn' voortgang van de afgelopen jaren wit meer dan alleen deze dissertatie. Alle vrienden en familie wil ik bedanken voor de gezelligheid, afleiding, belangstelling en steun waarvan ik de afgelopen jaren heb kunnen genieten. Jolanda Bonekamp en Ronald van Til wil ik bedanken voor hun steun op meerdere fronten. Klaas Sanders wil ik bedanken voor de rust en het vertrouwen die hij bracht in een belangrijke periode. In de 'Groningse weken' is de basis gelegd van de eerste hoofdstukken. Uit de gezellige wandeltochten, hardlooptochten, avonden uit en de gesprekken tijdens deze activiteiten met Mariëlle Goossens en Nathalie Heeren heb ik in de laatste maanden veel energie geput.

Mijn ouders bedank ik voor de gedegen basis die zij hebben gelegd in het bijbrengen van doorzettingsvermogen en verantwoordelijkheidsgevoel. Deze eigenschappen hebben mij geholpen om deze klus af te ronden.

Jolanda van Haastregt, Harold Nas en Annemarie Ruesink, ik vind het moeilijk onder woorden te brengen wat jullie de afgelopen jaren voor mij betekend hebben, elk op een heel eigen manier. Als geen ander zijn jullie betrokken geweest bij de voortgang van het hele proces waarbinnen deze dissertatie ontstond. Bedankt! Jullie rol in dit proces heeft voor mij minstens zoveel waarde als het product wat hier nu ligt. Zonder jullie had het er nu niet gelegen!

Ik hoop dat deze dissertatie geen eindpunt is, maar een product van verdere voortgang. Niet alleen ten aanzien van de voortgang van de voortgangstoets, maar ook wat betreft de samenwerking, collegialiteit en/of vriendschap die ik in dit proces heb mogen ervaren.

Cita van Til

Maastricht, mei 1998 



\section{Curriculum Vitae}

Cita van Til werd geboren op 31 mei 1967 in Dronten. In 1984 voltooide zij de HAVO aan het Nassau Veluwe College te Harderwijk. In datzelfde jaar begon zij met de Hogere Beroepsopleiding tot Verpleegkundige aan de Academie voor Gezondheidszorg in $Z$ wolle. Deze opleiding heeft zij in 1988 afgerond. Na twee jaar werkzaam te zijn geweest als verpleegkundige in het algemeen ziekenhuis en de wijkverpleging startte zij in 1990 met de studie Gezondheidswetenschappen, afstudeerrichting Verplegingswetenschap. Tijdens het laatste halfjaar van de studie was zij werkzaam als studentassistent bij de vakgroep Onderwijsontwikkeling en Onderwijsresearch van de Universiteit Maastricht. In 1993 voltooide zij cum-laude haar studie.

Aansluitend startte zij bij de vakgroep Onderwijsontwikkeling en Onderwijsresearch van de Universiteit Maastricht als Assistent in Opleiding voor de Faculteit der Gezondheidswetenschappen. Binnen de vakgroep combineerde zij vanaf 1996 deze functie met een functie als Docent ten behoeve van de Programma-Evaluatie voor de studie Psychologie.

Vanaf maart 1998 is zij werkzaam bij leerstoelgroep Agrarische Onderwijskunde van de Landbouwuniversiteit Wageningen waar de nadruk van haar functie ligt op advisering, begeleiding en evaluatie van onderwijsinnovatie binnen de universiteit. 